\title{
Analysis of the Effects of
} Compositional and Configurational Assumptions on Product Costs for the Thermochemical Conversion of Lignocellulosic Biomass to Mixed Alcohols - FY 2007 Progress Report

\author{
Y Zhu \\ MA Gerber \\ SB Jones \\ DJ Stevens
}

December 2008

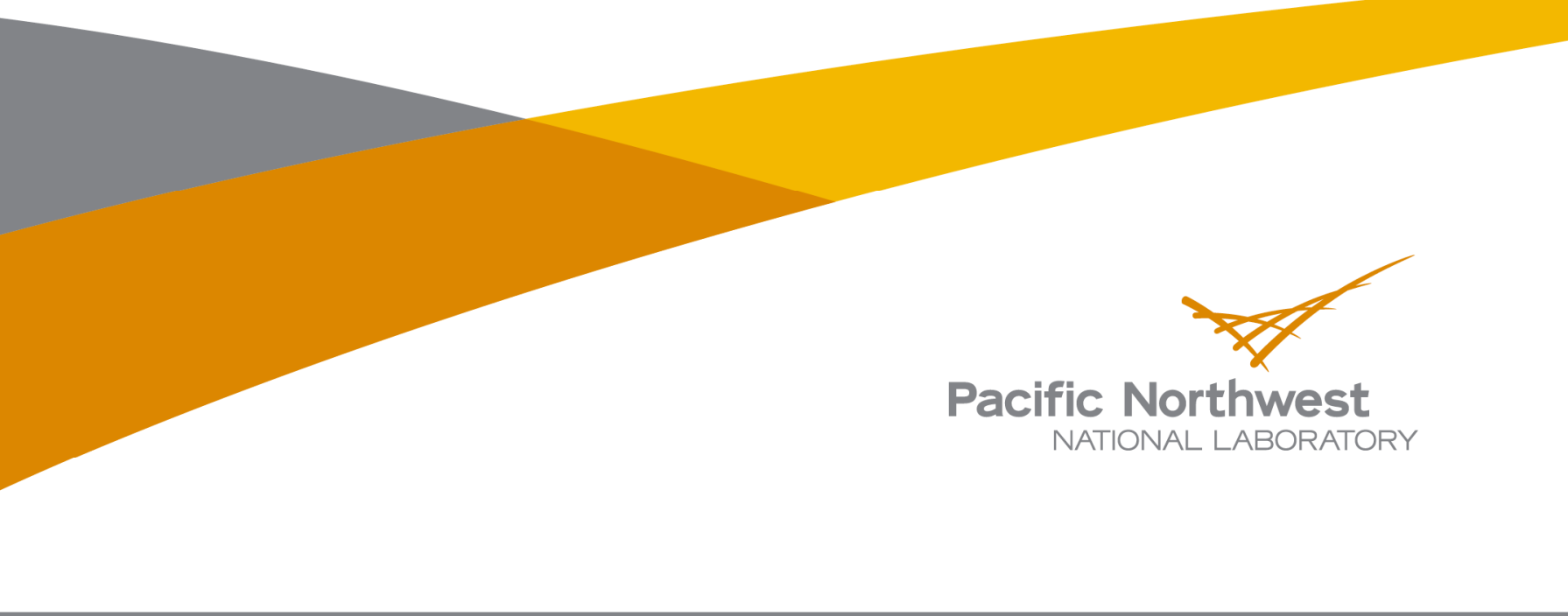




\title{
DISCLAIMER
}

This report was prepared as an account of work sponsored by an agency of the United States Government. Neither the United States Government nor any agency thereof, nor Battelle Memorial Institute, nor any of their employees, makes any warranty, express or implied, or assumes any legal liability or responsibility for the accuracy, completeness, or usefulness of any information, apparatus, product, or process disclosed, or represents that its use would not infringe privately owned rights. Reference herein to any specific commercial product, process, or service by trade name, trademark, manufacturer, or otherwise does not necessarily constitute or imply its endorsement, recommendation, or favoring by the United States Government or any agency thereof, or Battelle Memorial Institute. The views and opinions of authors expressed herein do not necessarily state or reflect those of the United States Government or any agency thereof.

\author{
PACIFIC NORTHWEST NATIONAL LABORATORY \\ operated by \\ BATTELLE \\ for the \\ UNITED STATES DEPARTMENT OF ENERGY \\ under Contract DE-AC05-76RL01830 \\ Printed in the United States of America \\ Available to DOE and DOE contractors from the \\ Office of Scientific and Technical Information, \\ P.O. Box 62, Oak Ridge, TN 37831-0062; \\ ph: (865) 576-8401 \\ fax: (865) 576-5728 \\ email: reports@adonis.osti.gov

\footnotetext{
Available to the public from the National Technical Information Service, U.S. Department of Commerce, 5285 Port Royal Rd., Springfield, VA 22161 ph: (800) 553-6847 fax: $(703) 605-6900$ email: orders@ntis.fedworld.gov

online ordering: http://www.ntis.gov/ordering.htm
} 


\section{Analysis of the Effects of Compositional and Configurational Assumptions on Product Costs for the Thermochemical Conversion of Lignocellulosic Biomass to Mixed Alcohols - FY 2007 Progress Report}

Y Zhu

MA Gerber

SB Jones

DJ Stevens

December 2008

Prepared for

the U.S. Department of Energy

under Contract DE-AC05-76RL01830

Pacific Northwest National Laboratory

Richland, Washington 99352 



\section{Executive Summary}

The purpose of this study was to examine alternative biomass-to-ethanol conversion process assumptions and configuration options to determine their relative effects on overall process economics. A process-flow-sheet computer model was used to determine the heat and material balance for each configuration that was studied. The heat and material balance was then input to a costing spreadsheet to determine the impact on the ethanol selling price. By examining a number of operational and configuration alternatives and comparing the results to the base flow sheet, alternatives having the greatest impact the performance and cost of the overall system were identified and used to make decisions on research priorities.

The process flow sheet was divided into the following four sections:

1. Gasification (includes feed preparation, the gasifier reactor, and gas particulate removal)

2. Gas purification and conditioning (includes tar cracking, acid gas removal, reforming, and compression)

3. Mixed alcohol synthesis and product separation and purification

4. Steam cycle and power generation.

CHEMCAD process modeling software was used to model the process configurations for an integrated biomass-to-mixed-alcohol conversion process based on two gasifier configurations:

1. An indirectly heated gasifier

2. A directly heated (oxygen-blown) pressurized gasifier.

The gasifier capacity was assumed to be 2000 dry tonnes per day of wood chips for all cases. Both gasifier models used similar processing assumptions and unit operation configurations as those used by Aden et al. (2005) in their milestone completion report and Spath et al. (2005) in their design report. Excel spreadsheet models were used to calculate the total equipment and operating costs using similar economic assumptions as used by Spath et al. (2005).

Several cases were examined for integrated processes using each gasifier configuration. Some of these cases examined process assumptions such as the raw gas composition and operating pressure, while others examined the effects of selected changes to the processes. Also, some of the cases were specific to one of the gasifier configurations while others were evaluated for both configurations. The motivation for selecting these cases and the implications of model limitations on interpretation of the results are discussed in the report.

Seven cases were considered for the mixed-alcohol synthesis plant with synthesis gas (syngas) produced by an indirectly heated gasifier.

In the Base Case, the gasifier syngas composition was based on correlations developed by Spath et al. (2005) for an indirectly heated gasifier. The balance of plant processing assumptions and unit operation configurations were similar to those used by Spath et al. (2005) and Aden et al. (2005). 
Two alternative cases, Case A1 and Case A2, were chosen to study the effects of syngas compostion and gasifier pressure.

- Case A1. The gasifier raw syngas composition had a $\mathrm{H}_{2}: \mathrm{CO}$ ratio close to $2: 1$ vs. $\sim 0.5$ for the base case.

- Case A2. The gasification pressure was increased to $147 \mathrm{psi}$ (10 atm) compared to $23 \mathrm{psig}$ for the Base Case. Because the gasifier model does not include a pressure factor, the syngas composition was assumed to be the same as that predicted at atmospheric pressure.

Two alternative cases, Case A3 and Case A4, were chosen to study the effects of changes to reformer/shift reactor configurations.

- Case A3: The steam reformer was replaced by a simple shift reactor. Methane and ethane were assumed to be inert in the synthesis step. The total syngas pressure was increased to maintain the same $\mathrm{H}_{2}$ and $\mathrm{CO}$ partial pressures as in the Base Case.

- Case A4. The same assumptions as in Case A3 applied, except that the total syngas pressure was unchanged from the Base Case.

Two alternative cases, Case A5 and Case A6, were chosen to study the effects of tar production.

- Case A5. The tar production rate was double that of the Base Case.

- Case A6. The tar production rate was half that of the Base Case.

Seven cases were also considered for the mixed-alcohol synthesis plant with synthesis gas (syngas) produced by a directly heated gasifier.

In the Base Case, the raw gas composition was from correlations developed by Eggeman (2005) based on experimental data reported in Evans et al. (1988) using the Gas Technology Institute's 12 tons per day process research unit.

Two alternative cases, Case B1 and Case B2, were chosen to study the effects of gasifier pressure and syngas composition.

- Case B1. The gasification pressure was decreased to $20 \mathrm{psig}$, compared to $330 \mathrm{psig}$ for the Base Case. The syngas is assumed to have the same composition as that predicted at higher pressure.

- Case B2. The gasification pressure was changed to $20 \mathrm{psig}$. The syngas composition was adjusted by extrapolating the gasifier correlations to $20 \mathrm{psig}$.

Two alternative cases, Case B3 and Case B4, were chosen to study the effects of changes to reformer/shift configurations.

- Case B3. The steam reformer was replaced by a simple shift reactor. Methane and ethane were assumed to be inert in the synthesis step. The total syngas pressure was increased to maintain the same $\mathrm{H}_{2}$ and $\mathrm{CO}$ partial pressures as in the Base Case.

- Case B4. The same assumptions as in Case A3 apply, except that the total syngas pressure was not changed from the Base Case. 
Two alternative cases, Case B.5 and Case B.6, were chosen to study the effects of tar production.

- Case B5. The tar production rate was double that of the Base Case.

- Case B6. The tar production rate was one-half of that in the Base Case.

Simulation results and analysis for the alternative cases evaluated in this study point to the potential importance of operating the gasifier at elevated pressure, and minimizing gasifier products that ultimately lead to decreased production of $\mathrm{H}_{2}$ and $\mathrm{CO}$ in the clean synthesis gas. Specifically, we found that minimizing char production in the gasifiers, the amount of unconverted tar in the tar cracker, and the amount of unconverted methane leaving the methane reformer led to higher quantities of $\mathrm{H}_{2}$ and $\mathrm{CO}$ that could be converted into mixed alcohols, thereby decreasing unit production costs. Generally, we found that relatively small increases in mixed alcohol production efficiency more than offset the capital and annual operating costs required to achieve these improvements.

We also found that consideration should also be given to operating the gasifier in a manner that best matches the $\mathrm{H}_{2}$ :CO ratio requirements of the alcohol synthesis reactor without requiring significant forward or reverse water-gas shift (WGS) in the methane reforming/WGS reactor. 



\section{Acronyms and Abbreviations}

\begin{tabular}{|c|c|}
\hline${ }^{\circ} \mathrm{C}$ & degrees Celsius \\
\hline${ }^{\circ} \mathrm{F}$ & degrees Fahrenheit \\
\hline$\$ \mathrm{~mm} / \mathrm{yr}$ & million dollars per year \\
\hline ASU & air separation unit \\
\hline atm & atmospheres \\
\hline BTU & British Thermal Units \\
\hline $\mathrm{C}_{2} \mathrm{H}_{2}$ & acetylene \\
\hline $\mathrm{C}_{2} \mathrm{H}_{4}$ & ethylene \\
\hline $\mathrm{C}_{2} \mathrm{H}_{6}$ & ethane \\
\hline CEPCI & Chemical Engineering Plant Cost Index \\
\hline $\mathrm{CH}_{4}$ & methane \\
\hline $\mathrm{CO}$ & carbon monoxide \\
\hline $\mathrm{CO}_{2}$ & carbon dioxide \\
\hline $\operatorname{COS}$ & carbonyl sulfide \\
\hline $\mathrm{CS}_{2}$ & carbon disulfide \\
\hline EIA & Energy Information Administration \\
\hline $\mathrm{EtOH}$ & ethanol \\
\hline FT & Fischer-Tropsch \\
\hline G\&A & general and administrative (costs) \\
\hline gal & gallon(s) \\
\hline $\mathrm{H}_{2}$ & hydrogen \\
\hline $\mathrm{H}_{2} \mathrm{O}$ & water \\
\hline $\mathrm{H}_{2} \mathrm{~S}$ & hydrogen sulfide \\
\hline HP & high pressure \\
\hline $\mathrm{lb}$ & pound(s) \\
\hline LP & low pressure \\
\hline $\mathrm{N}_{2}$ & nitrogen \\
\hline
\end{tabular}




$\begin{array}{ll}\mathrm{NH}_{3} & \text { ammonia } \\ \mathrm{O}_{2} & \text { oxygen } \\ \text { psia } & \text { pounds per square inch absolute } \\ \text { psig } & \text { pounds per square inch gage } \\ \text { ROI } & \text { return on investment } \\ \text { scf } & \text { standard cubic feet } \\ \text { syngas } & \text { synthesis gas } \\ \text { TPEC } & \text { total purchased equipment cost } \\ \text { WGS } & \text { water-gas shift } \\ \text { yr } & \text { year(s) } \\ \text { ZnO } & \text { zinc oxide }\end{array}$




\section{Contents}

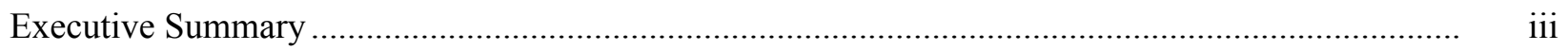

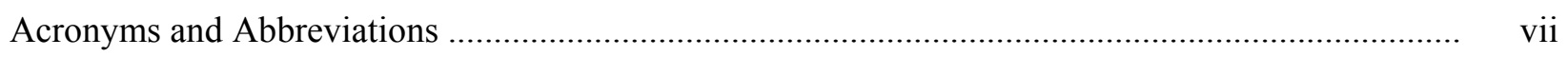

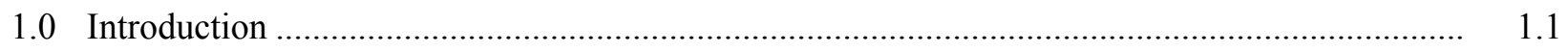

2.0 Process Design Basis and Modeling Approach ............................................................ 2.1

2.1 Biomass Gasification Section Model ................................................................................ 2.1

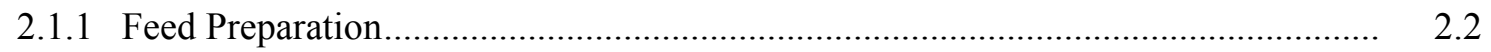

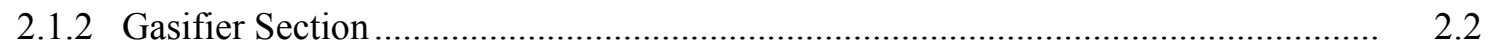

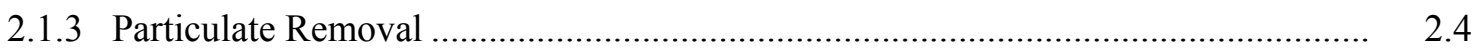

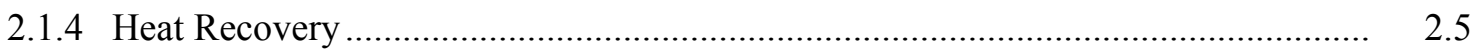

2.2 Gas Purification and Conditioning Model.................................................................... 2.5

2.2.1 Tar Removal ........................................................................................... 2.6

2.2.2 Water Scrubber/Acid Gas Removal .............................................................. 2.6

2.2.3 Methane Reforming and Water-Gas Shift Reactor ........................................... 2.8

2.2.4 $\mathrm{CO}_{2}$ Removal and Compression .................................................................. 2.8

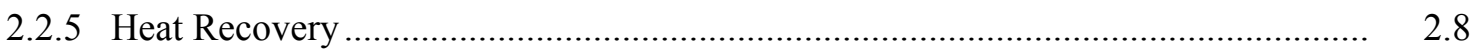

2.3 Alcohol Synthesis and Product Recovery Model ........................................................ 2.9

2.3.1 Alcohol Synthesis Reactor ......................................................................... 2.9

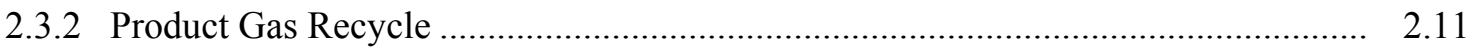

2.3.3 Liquid Separation and Purification................................................................ 2.12

2.3.4 Methanol Byproduct Recycle ................................................................... 2.12

2.4 Steam-Cycle and Power-Generation Model............................................................ 2.12

2.5 Overall Process Modeling and Cost Estimation Methodology ......................................... 2.14

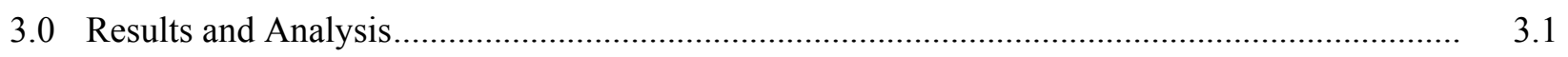

3.1 Indirectly Heated Gasifier Scenarios.......................................................................

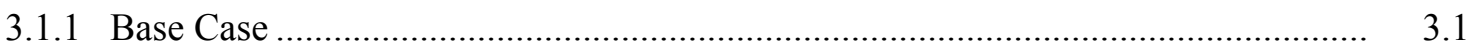

3.1.2 Case A1: Raw Gas Composition with $\mathrm{H}_{2}$ : $\mathrm{CO}$ Ratio Close to $1.7: 1$....................... 3.4

3.1.3 Case A2. Gasifier Pressure Increases to 10 Atm ..................................................... 3.5

3.1.4 Case A3. Methane/Ethane are not Reformed and Clean Syngas Pressure Changed to Maintain $\mathrm{H}_{2} / \mathrm{CO}$ Partial Pressures ...................................................... 3.7

3.1.5 Case A4. Methane/Ethane is Assumed to be Inert and Clean Syngas Pressure Unchanged.................................................................................................. $\quad 3.8$

3.1.6 Case A5: Tar Production is Assumed to be Double that of Base Case .................... 3.9

3.1.7 Case A6: Tar Production is Assumed to be Half that of the Base Case .................. 3.10

3.2 Directly Heated Gasifier Scenarios ........................................................................... 3.11

3.2.1 Base Case .............................................................................................. 3.11

3.2.2 Case B1. Gasifier Pressure Decreases and Sygnas Compositions are Unchanged... 3.14

3.2.3 Case B2. Gasifier Pressure Decreases and Sygnas Compositions are Changed ...... 3.15 
3.2.4 Case B3. Methane/Ethane are not Reformed and the Clean Syngas Pressure is Changed

3.2.5 Case B4. Methane/Ethane are not Reformed and Clean Syngas Pressure is Unchanged.

3.2.6 Case B5. Tar Production is Assumed to be 1.5 Times that of the Base Case

3.2.7 Case B6. Tar Production is Assumed to be Half that of the Base Case .

4.0 Conclusions

Appendix A - Equipment Cost Details

\section{Figures}

1.1 Block Flow Diagram for Biomass Gasifier-Based Mixed Alcohol Synthesis Systems

2.1 Feed Preparation and Gasification Section for the Indirectly Heated Gasifier

2.2 Feed Preparation and Gasification Section for the Directly Heated Pressurized Gasifier.........

2.3 Gas Purification and Conditioning Section for Both Gasifier Types.

2.4 Lo-Cat Process

2.5 Mixed Alcohol Synthesis and Purification Section

2.6 Steam and Power Generation Section for the Process Using and Indirectly Heated Gasifier ...

\section{Tables}

2.1 Correlation Equation Factors for the Indirectly-Heated Gasifier.

2.2 Correlation Equation Factors for the Directly Heated Gasifier

2.3 Design Performance of Tar Reformer.

2.4 Design Assumptions for Mixed Alcohol Synthesis

2.5 Reaction Stoichiometry and Base-Case Reactant Conversions for Mixed Alcohol Synthesis.....

2.6 Total Project Investment for the Design Case Standalone Plant.

2.7 Economic Assumptions

3.1 Performance Results for Indirectly Heated Gasifier Based System Models..

3.2 Equipment and Capital Cost Results for Indirectly Heated Gasifier Based System Models.............

3.3 Operating Cost Results for Indirectly Heated Gasifier Based System Models

3.4 Performance Results for Directly Heated Gasifier Based System Models

3.5 Equipment and Capitals Costs for Directly Heated Gasifier Based System Models

3.6 Operating Costs for Directly Heated Gasifier Based System Models 


\subsection{Introduction}

In 2006, the President of the United States proposed the Advanced Energy Initiative that outlined significant new investments and policies to reduce our dependence on foreign oil supplies by, among other options, changing the way we fuel our vehicles. Implicit in this initiative is a switch from petroleum-based transportation fuels that depend largely on foreign oil supplies to alternative transportation fuels based on other domestic resources. The Energy Independence and Security Act of 2007 (EISA) requires increased biofuel production to be expanded from the original mandate of 7.5 billion gallons by 2012 to a mandate of 36 billion gallons by 2022 . The minimum of this requirement must be from advanced biofuels, cellulosic biofuels, and biodiesel fuel.

One domestic resource that has the potential for a significant impact on domestic fuels is biomass. Biomass is a renewable energy resource that can be converted into forms suitable for transportation applications. Currently, these applications are mostly met through the conversion of grain products into fuel-grade ethanol that can be blended with gasoline. Smaller quantities of biomass in the form of vegetable oils have been converted into esters that are suitable for use as diesel fuel. However, while these forms of biomass can supply small but significant quantities of transportation fuels for our domestic needs, other more widely available biomass forms, specifically lignocellulosic biomass forms, also need to be used to have a major impact on domestic supplies of transportation fuel. Ethanol can be produced from lignocellulosic feedstock using two different methods.

1. Directly using advanced bioconversion technologies to convert the cellulose and hemicellulose fractions of the feedstock into ethanol.

2. Indirectly by first gasifying the entire feedstock into a raw gas that then can be further purified and conditioned into a synthesis gas (syngas) (nominally carbon dioxide $\left[\mathrm{CO}_{2}\right]$ and hydrogen $\left[\mathrm{H}_{2}\right]$ ) suitable for alcohol synthesis.

Both methods have technology challenges that will need to be addressed before commercially viable processes are available. To improve the market competitiveness of bioenergy products, research is needed to improve system integration, optimize system design, increase efficiency, and finally lower the cost.

Figure 1.1 shows the simplified process flow for a biomass gasifier-based mixed alcohol synthesis system. The main components are gasification, gas purification and conditioning (tar cracking, acid gas removal, reforming, and compression), mixed alcohol synthesis, and steam cycle/power generation. In this system, wood chips are converted to raw gas in a gasifier. This gas then is sent to a tar reformer and scrubber. The tar and particulate-free gas is sent to a sulfur-removal unit. After gas conditioning and adjustment of the $\mathrm{H}_{2}$ : $\mathrm{CO}$ ratio, the resulting syngas is converted into mixed alcohols and then separated into products. Byproducts and unconverted synthesis gas that are unsuitable for recovery, reuse, or sale are used as fuel to produce electricity.

To achieve technical and economic viability for indirect syntheses of alcohol via biomass gasification, two broad issues need to be addressed: 1) creating a syngas that is sufficiently clean for alcohol synthesis and 2) developing a catalyst that can achieve the necessary productivity and selectivity to yield fuel-grade ethanol. 
Obtaining a sufficiently clean synthesis gas involves several unit operations, including gasification, tar and particulate elimination, compositional adjustment of the product gas (steam reforming of methane, water-gas shift [WGS], $\mathrm{CO}_{2}$ removal), and reduction in the concentration of potential catalyst poisons including, but not limited to, low concentrations of sulfur containing species $\left(\mathrm{H}_{2} \mathrm{~S}, \mathrm{COS}, \mathrm{CS}_{2}\right)$, chlorides and alkali-containing species. At this time, biomass gasification technologies have been developed to the point of large-scale demonstrations that potentially are applicable to the production of syngas. However, widespread commercialization of large-scale gasifiers or their integration with liquid fuel synthesis technology has not been realized. There are a number of commercial technologies and advanced technologies under development that can impact the other unit operations and, in turn, the overall process economics for producing a suitable syngas. Ethanol synthesis from a $\mathrm{H}_{2} / \mathrm{CO}$ syngas has not reached the same point of development as gasification. Currently available catalysts tend to produce a variety of coproducts and have relatively low activities when compared to methanol synthesis, which is a commercial process. Several options are available for addressing these issues; however, the economic tradeoffs between product selectivity and productivity are not straight forward.

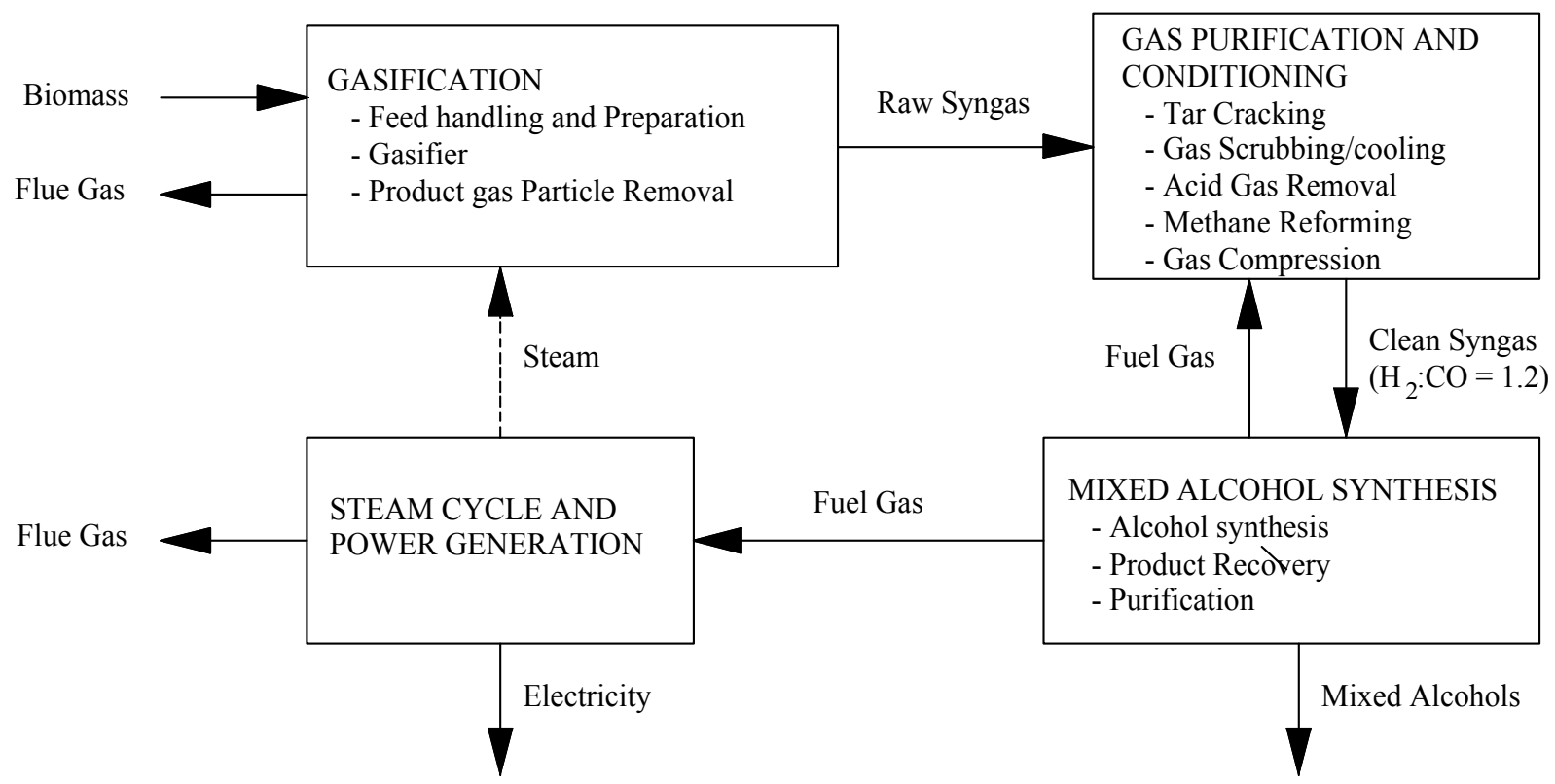

Figure 1.1. Block Flow Diagram for Biomass Gasifier-Based Mixed Alcohol Synthesis Systems

There are a number of operational parameters and process configuration options that affect the cost of producing ethanol from syngas derived from biomass gasification. Among these are the operating pressure of the gasifiers, the efficiency of the process for converting biomass to gas, the method chosen for purifying and adjusting the composition of the gas, the syngas-to-mixed alcohol conversion efficiency, selectivity and productivity, and methods chosen to recover and recycle or otherwise use the nonalcoholic byproducts of syngas conversion. Often changes in individual operational parameters and process configuration options result in changes in operating parameters throughout the integrated process that can affect both equipment and operating costs. A robust computerized process simulation model can be a valuable tool for tracking the effects of these changes and their impact on the costs for the various unit operations. By changing process assumptions of individual unit operations or introducing alternative unit operations and configurations, the simulation model can track process stream changes throughout all unit operations that, in turn, can be used to quantify changes in equipment and operating costs for each 
operation. By identifying those changes that have the greatest impact, research can be more effectively directed toward achieving economic viability by 1) focusing research in the key areas and 2) setting processing milestones to measure technical progress.

A number of techno-economic assessments using process design and simulation models have been conducted for biomass gasification to produce a number of products including methanol (Hamelinck and Faaij 2002), Fischer-Tropsch (FT) liquid-based transportation fuels ((Hamelinck et al. 2003), hydrogen (Hamelinck and Faaij 2002; Spath et al. 2005), and ethanol (Aden et al. 2005; Phillips et al. 2007). The latter two studies on ethanol production via biomass gasification/ethanol synthesis focused primarily on the development of process simulation models for base process designs to develop goal-case ethanol product prices. Limited sensitivity analyses of selected technical and economic assumptions on overall product costs also were performed in each study.

The purpose of this study was to examine alternative process assumptions and configuration options to determine the relative effects these have on overall biomass-to-ethanol conversion economics. A process-flow-sheet computer model was used to determine the heat and material balance for each configuration. The heat and material balance then was input to a costing spreadsheet to determine the impact on the ethanol selling price. By examining a number of operational and configurational alternatives to the base flow sheet, those alternatives having the greatest impact the performance and cost of the overall system can be identified and used to make decisions on research priorities. 



\subsection{Process Design Basis and Modeling Approach}

CHEMCAD process modeling software was applied to model process configurations for an integrated process used to produce mixed alcohols from biomass. The processes are based on both an indirectly heated gasifier and a directly heated (oxygen-blown) pressurized gasifier. The gasifier capacity is assumed to be 2000 dry tonne/day wood chips for all cases. Both gasifier models used similar processing assumptions and unit operation configurations as those used by Aden et al. (2005) in their milestone completion report and Spath et al. (2005) in their design report. Excel spreadsheet models were used to calculate the total equipment and operating costs using similar economic assumptions as Phillips et al. (2007), Aden et al. (2005), Hamelinck et al. (2003), and Hamelinck and Faaij (2002). The process flow sheet was divided into four sections so the effects of parameter and configurational changes could be more clearly understood. The systems shown in Figure 1.1 are described in the following sections.

\subsection{Biomass Gasification Section Model}

The biomass gasification section includes the unit operations related to feed preparation and gasification and product gas particulate removal systems. This is shown in Figure 2.1 for the indirectly heated gasifier and Figure 2.2 for the directly heated gasifier.

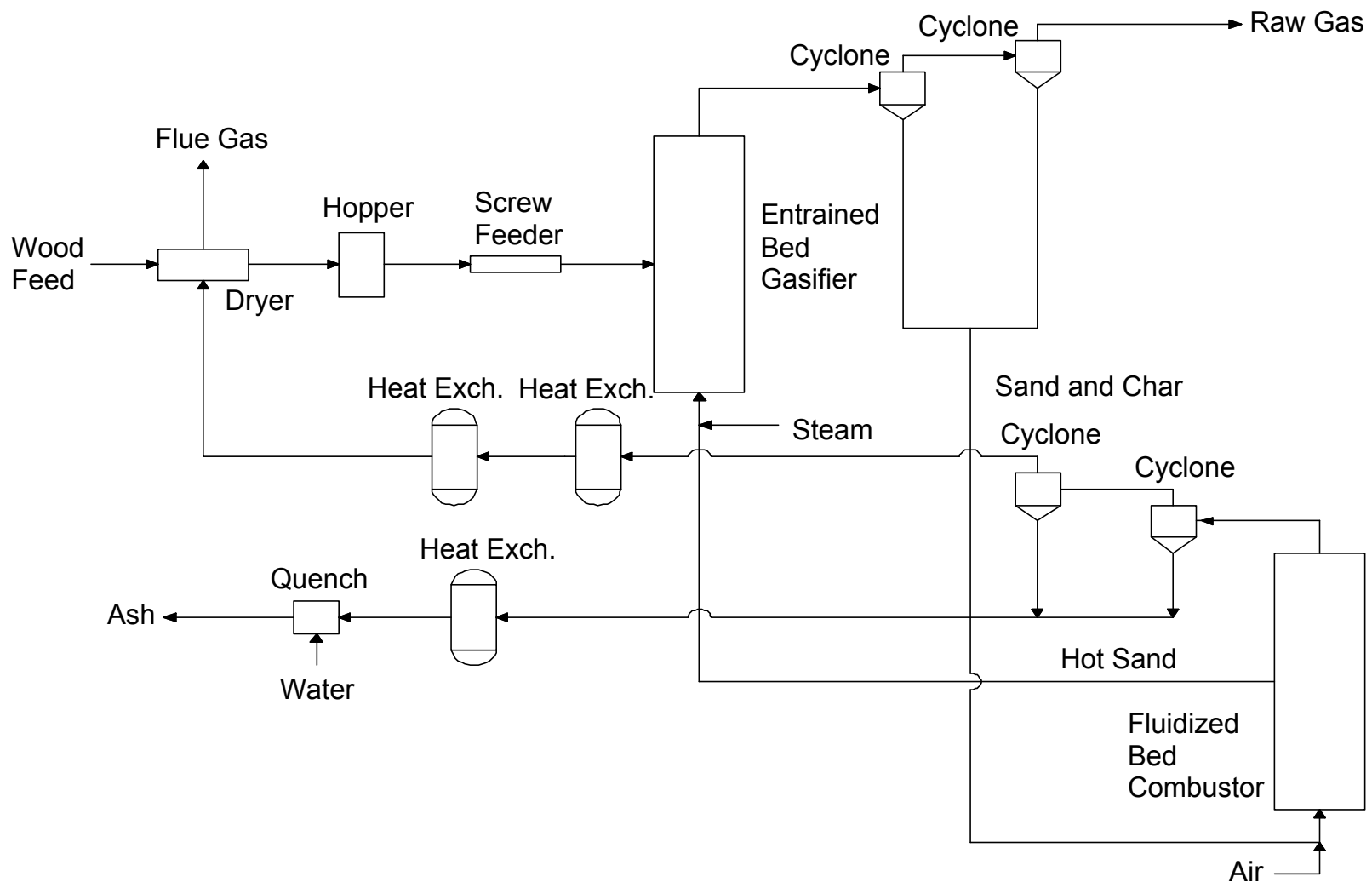

Figure 2.1. Feed Preparation and Gasification Section for the Indirectly Heated Gasifier 


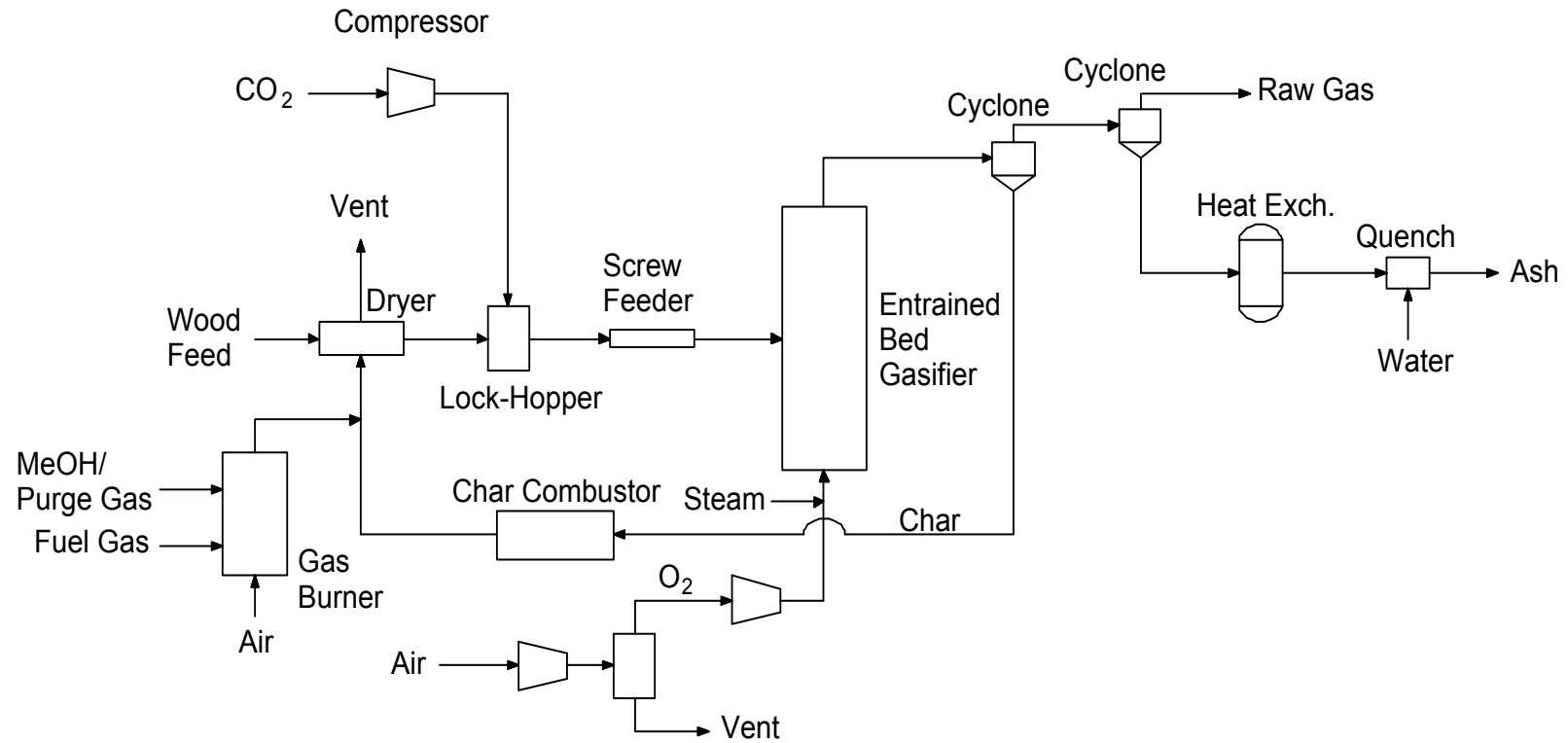

Figure 2.2. Feed Preparation and Gasification Section for the Directly Heated Pressurized Gasifier

\subsubsection{Feed Preparation}

Biomass is assumed to be received in the form of wood chips with a moisture content of $50 \mathrm{wt} \%$ (the wood feed rate to the feed preparation system is 4000 wet tonnes per day). The wood chips are dried in rotary driers. Pre-drying the feedstock before feeding it to the gasifier is necessary to minimize the heat load in the gasifier, thereby reducing char combustion requirements in the indirectly heated gasifier and oxygen requirements in the directly heated gasifier. However, drying wood chips to a moisture content less than 10 to $15 \%$ is more energy intensive and requires significantly larger dryers (Hamelinck et al. 2003). In this study, a moisture content of $12 \%$ is assumed based on a previous study that used wood as the feedstock (Spath et al. 2005).

For the indirectly heated gasifier, the heat from the char combustor hot flue gas is used to produce steam and dry the biomass. The flue gas stack exit temperature is controlled to be greater than the gas dew point (i.e., approximately $300^{\circ} \mathrm{F}$ ). For the oxygen-blown pressurized gasifier, the heat of the flue gas from the char combustor is insufficient to completely dry the wood chips. Therefore, off-gas from the synthesis process is burned to generate additional heat for biomass drying.

\subsubsection{Gasifier Section}

The indirectly heated gasifier is modeled using the correlation model developed by Spath et al. (2005) based on data from a gasifier developed at Battelle-Columbus Laboratory. A 182-dry-tonne/day demonstration-scale gasifier design was later built by Future Energy Resources Company (FERCO), Atlanta, Georgia, at a Burlington Electric Department wood powered plant in Burlington, Vermont. The syngas from the directly heated (oxygen-blown) pressurized gasifier is predicted using correlations based on the experimental data from an Institute of Gas Technology gasifier (Evans 1988). A 90-tonne/day demonstration plant based on this design was built at the Hawaiian Commercial \& Sugar Company's Paia sugar factory in Maui, Hawaii, and operated using bagasse (i.e., the biomass remaining after sugarcane 
stalks are crushed to extract their juice) as the feedstock. Both types of gasifiers were modeled using the stoichiometric reactor model in CHEMCAD.

Indirectly Heated Gasifier. The indirectly heated gasifier (Figure 2.1) contains both a gasifier and a separate combustor. Dried wood is fed into a low-pressure indirectly heated gasifier. Steam extracted from the steam cycle is sent to the gasifier at a flow rate of $0.4 \mathrm{lb}$ of steam/lb of bone-dry wood to fluidize the bed and to supply a portion of the heat required for the gasifier. The Base-Case gasifier, which is heated by circulating hot olivine particles between the gasifier and the separate combustor (Spath et al. 2005), is operated at $1598^{\circ} \mathrm{F}$ and 23 psi. A mixture of char formed in the gasifier and olivine particles are removed from the gasifier by separation in a series of cyclone separators, and then sent to the fluidized bed combustor where air is used to burn the char and reheat the olivine. The reheated olivine is then returned to the gasifier. The char combustor temperature is set at $1800^{\circ} \mathrm{F}$. The olivine circulating flow rate is $27 \mathrm{lb}$ of olivine/lb of bone-dry wood. Fresh olivine is made up at a rate of $0.1 \%$ of the circulating rate to replace material not captured in the cyclone separators. A small amount of $\mathrm{MgO}$ is added to the olivine to avoid the formation of a low melting point glass caused by reaction with potassium in the biomass ash. $\mathrm{The} \mathrm{MgO}$ reacts with the potassium to form a higher melting point material.

For the indirectly-heated gasifier model, the following quadratic function is used to estimate the composition of all of the gas components, tar, and char) (Spath et al. 2005):

$$
\left(\mathrm{A}+\mathrm{B}^{*} \mathrm{~T}+\mathrm{C}^{*} \mathrm{~T}^{2}\right)
$$

The correlation equation factors are listed in Table 2.1.

Table 2.1. Correlation Equation Factors for the Indirectly-Heated Gasifier

\begin{tabular}{lrrr}
\hline $\begin{array}{c}\text { Gas Components } \\
\text { (mol\% of dry gas) }\end{array}$ & $\mathrm{A}$ & \multicolumn{1}{c}{$\mathrm{B}$} & \multicolumn{1}{c}{$\mathrm{C}$} \\
\hline $\mathrm{H}_{2}$ & 17.996 & -0.026448 & $1.8930^{*} 10^{-5}$ \\
$\mathrm{CO}$ & 133.46 & -0.10290 & $2.8792 * 10^{-5}$ \\
$\mathrm{CO}_{2}$ & -9.5251 & 0.037889 & $-1.4927 * 10^{-5}$ \\
$\mathrm{CH}_{4}$ & -13.82 & 0.044179 & $-1.6167 * 10^{-5}$ \\
$\mathrm{C}_{2} \mathrm{H}_{2}$ & -4.3114 & $5.4499 * 10^{-3}$ & $-1.561 * 10^{-6}$ \\
$\mathrm{C}_{2} \mathrm{H}_{4}$ & -38.258 & 0.058435 & $-1.9868 * 10^{-5}$ \\
$\mathrm{C}_{2} \mathrm{H}_{6}$ & 11.114 & -0.011667 & $3.064 * 10^{-6}$ \\
Solids components & & & \\
$(\mathrm{lb} / \mathrm{lb}$ bone dry wood) & & & \\
$\mathrm{Char}$ & 0.75503 & $-3.0212 * 10^{-4}$ & $-3.1178 * 10^{-8}$ \\
Tar & 0.045494 & $-1.9759 * 10^{-5}$ & \\
\hline
\end{tabular}

Tar is simulated as 33.3 mole\% benzene and 66.7 mole\% naphthalene (Spath 2005).

Directly Heated Gasifier. The directly heated gasifier (Figure 2.2) is a pressurized fluidized bed reactor. Steam is used to fluidize the gasifer bed and to provide a portion of the heat. The steam flow rate is $0.2 \mathrm{lb}$ of steam/lb of dry wood with $12 \mathrm{wt} \% \mathrm{H}_{2} \mathrm{O}$. The mass flow rate of oxygen is varied to achieve a $1600^{\circ} \mathrm{F}$ gasifier outlet temperature. The sub-stoichiometric flow rate of oxygen burns a portion of the biomass, thereby supplying heat for the endothermic gasification reactions. Purified oxygen is required rather than air to prevent introducing large quantities of nitrogen into the synthesis gas where it would act as an inert diluent. A pressurized cryogenic air separation unit provides purified oxygen at $99.5 \%$ for the 
gasifier at $350 \mathrm{psia}$ and $60^{\circ} \mathrm{F}$. The dried wood is fed using a lock hopper feeder system in which wood is dropped into a chamber, which is then sealed, and then filled with pressurized $\mathrm{CO}_{2}$ recovered from the gas purification and conditioning section of the plant. Once the chamber is pressurized, the wood is discharged from the lock hopper and fed to the gasifier. The $\mathrm{CO}_{2}$ used in the lock hopper is fed at a flow rate of $0.03 \mathrm{lb}$ of $\mathrm{CO}_{2} / \mathrm{lb}$ dried wood and compressed to $330 \mathrm{psi}$. A small amount of $\mathrm{MgO}$ is added to the gasifier to react with potassium in the ash to prevent agglomeration in the gasifier bed.

For the directly heated gasifier model, the following function was used to estimate the gas composition, tar (modeled as benzene and naphthalene), and char (Eggeman 2005):

$$
\left(\mathrm{A}+\mathrm{B} * \mathrm{P}+\mathrm{C}^{*} \mathrm{~T}+\mathrm{D}^{*}\left(\mathrm{O}_{2} / \text { Feed } \mathrm{C}\right)+\mathrm{E}\left(\mathrm{H}_{2} \mathrm{O} / \text { Feed } \mathrm{C}\right)\right)
$$

The correlation equation factors are listed in Table 2.2.

Table 2.2. Correlation Equation Factors for the Directly Heated Gasifier

\begin{tabular}{lrrrrr}
\hline \multicolumn{1}{c}{$\begin{array}{c}\text { Gas Components } \\
\text { (lbmol ratio) }\end{array}$} & \multicolumn{1}{c}{$\mathrm{A}$} & \multicolumn{1}{c}{$\mathrm{B}$} & \multicolumn{1}{c}{$\mathrm{C}$} & \multicolumn{1}{c}{$\mathrm{D}$} & \multicolumn{1}{c}{$\mathrm{E}$} \\
\hline $\mathrm{H}_{2} /$ Feed H & -0.3830761 & $1.894350^{*} 10^{-4}$ & $2.666675^{*} 10^{-4}$ & 0.1060088 & $7.88095510^{-2}$ \\
$\mathrm{CO} /$ Feed C & $-8.130017 * 10^{-2}$ & $-3.340050 * 10^{-4}$ & $2.614482 * 10^{-4}$ & 0.1495730 & $-5.26836710^{-2}$ \\
$\mathrm{CO}_{2} /$ Feed C & $7.157172 * 10^{-2}$ & $3.843454^{*} 10^{-4}$ & $1.286060^{*} 10^{-5}$ & 0.6124545 & $9.98086810^{-2}$ \\
$\mathrm{CH}_{4} /$ Feed C & $1.093589 * 10^{-2}$ & $1.388446 * 10^{-4}$ & $8.812765^{*} 10^{-5}$ & -0.2274854 & $3.42782510^{-2}$ \\
$\mathrm{C}_{2} \mathrm{H}_{4} /$ Feed C & $5.301812 * 10^{-2}$ & $-6.740399 * 10^{-5}$ & $-1.372749 * 10^{-5}$ & $-9.076286^{*} 10^{-3}$ & $-4.85408210^{-3}$ \\
$\mathrm{C}_{2} \mathrm{H}_{6} /$ Feed C & 0.1029750 & $-5.440777 * 10^{-6}$ & $-5.350103 * 10^{-5}$ & $-3.3770910^{-2}$ & $-1.91533910^{-3}$ \\
Benzene/Feed C & $4.676833 \mathrm{E}^{*} 10^{-2}$ & $-1.937444 * 10^{-5}$ & $-1.270868 * 10^{-5}$ & $-1.046762 * 10^{-2}$ & $-8.45964710^{-3}$ \\
Naphthalene/Feed C & $1.827359 * 10^{-2}$ & $-2.328921 * 10^{-6}$ & $-5.951746^{*} 10^{-6}$ & $-1.936385 * 10^{-2}$ & $-7.678310^{*} 10^{-4}$ \\
Solids Components & & & & & \\
(mol\% of feed) & & & & & \\
\% of Feed N in Char & 3.36 & & & & \\
\% of Feed S in Char & 8.45 & & & & \\
\% of Feed O in Char & 1.512040 & $1.582010 * 10^{-4}$ & $-6.972612 * 10^{-4}$ & 0.1573581 & -0.142091 \\
\hline
\end{tabular}

\subsubsection{Particulate Removal}

A series of cyclone separators are used to remove particulates and char from the raw gas leaving the gasifier. In the indirectly heated gasifier, the majority of the olivine, char, and ash is separated in the primary gasifier cyclone separator and then sent to the char combustor. The gas from the primary gasifier cyclone is sent to the tar reformer. The char is burned in the char combustor to reheat the olivine. The flue gas from the char combustor is sent to the primary combustor cyclone separator, which separates $99.9 \%$ of the olivine which then is returned to the gasifier. Then, the flue gas containing residual fines and ash is sent to a secondary combustor cyclone separator to remove these solids. The residual fines and ash are cooled to $300^{\circ} \mathrm{F}$ using cooling water to control dust, and the wet solids ultimately are transported to a landfill for disposal.

In the directly heated gasifier, the raw untreated gas from the gasifier is sent to a primary cyclone separator where char is captured and sent to the char combustor. The gas from the primary separator is then sent to a secondary cyclone separator to remove the ash and residual fines. The ash recovered from the secondary separator is cooled to $300^{\circ} \mathrm{F}$, and then water is added before the mixture is transported to a landfill for disposal. 


\subsubsection{Heat Recovery}

In the indirectly heated gasifier system, part of the sensible heat of the hot flue gas from the char combustor is recovered by generating high-pressure saturated steam at 1280 psi. This steam is superheated by heat removed from the steam reformer, and then used in a steam turbine to generate electricity. The cooled flue gas is sent to the feed dryer to provide heat for wood drying. For the directly heated gasifier, the heat of flue gas is used only for biomass drying.

\subsection{Gas Purification and Conditioning Model}

The gas purification and conditioning section shown in Figure 2.3 is similar for both gasifier systems. Hot gas, leaving the cyclone separators from the gasifier section, enters a tar-cracking/reforming unit to eliminate tar from the gas. A portion of the methane and light hydrocarbon gases are reformed in the tarcracking/reforming unit. The tar-free gas is quenched in a water scrubber to cool the gas and condense water in the gas. The scrubbed syngas is compressed to $450 \mathrm{psig} . \mathrm{H}_{2} \mathrm{~S}$ in the syngas then is removed with a liquid-phase oxidation process (LO-CAT ${ }^{\circledR}$ ), followed by $\mathrm{ZnO}$ polishing. The treated gas is combined with steam and recycled $\mathrm{CO}_{2}$ and sent to a methane reformer where methane and other higher hydrocarbon gases are reformed to $\mathrm{CO}$ and $\mathrm{H}_{2}$ in a desired ratio. An amine-based chemical absorption system removes $\mathrm{CO}_{2}$ from the reformed syngas. The purified synthesis gas is compressed to the desired pressure for mixed alcohol synthesis. High-temperature heat is recovered from the steam reformer process effluent and flue gas. Low-temperature process heat is rejected to the atmosphere and to water-cooled trim exchangers.

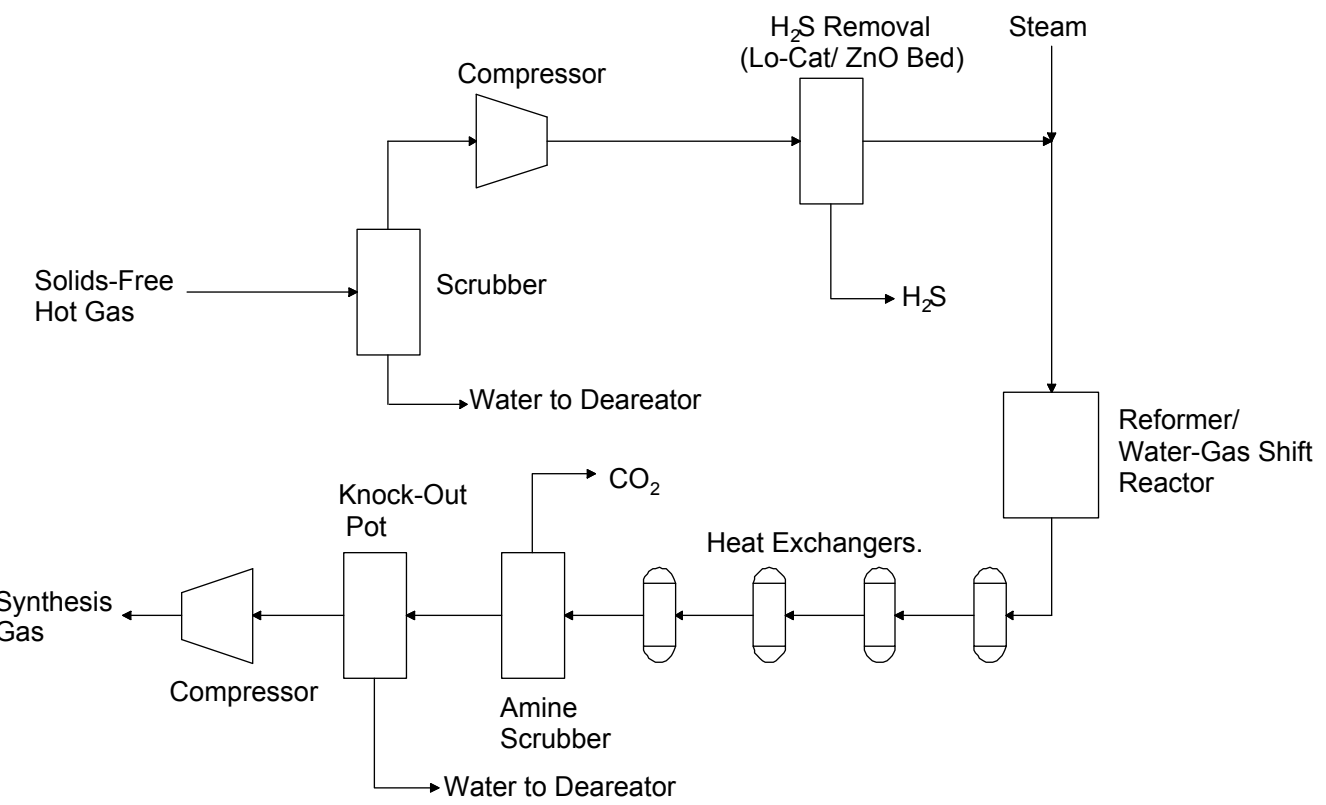

Figure 2.3. Gas Purification and Conditioning Section for Both Gasifier Types

The principal differences in the gas purification and conditioning section for the two gasifier configurations are in the compression costs. The indirectly heated gasifier system produces low-pressure syngas that requires significant compression prior to gas cleanup. The directly heated gasifier produces pressurized raw syngas that requires less compression. In addition, the indirectly heated gasifier syngas 
composition is such that steam and compressed, recycled $\mathrm{CO}_{2}$ is needed in the steam reformer to obtain the desired $\mathrm{H}_{2}$ : $\mathrm{CO}$ ratio for the synthesis step. The gas from the directly heated gasifier needs only steam addition to the steam reformer.

\subsubsection{Tar Removal}

During gasification, a small fraction of the biomass is converted into tars that consist primarily of functionalized aromatic and poly-aromatic hydrocarbons. The tars will foul the downstream process equipment if allowed to condense. While they comprise only a small fraction of the wood feed, they contain significant quantities of carbon and hydrogen, which are important sources for $\mathrm{CO}$ and $\mathrm{H}_{2}$. Therefore, cracking these tars into small hydrocarbons is preferred over condensing them in the water scrubber and discharging them with the wastewater.

The raw gas from the cyclone separator in the gasifier section is sent to a catalytic tar cracker, which is assumed to be a bubbling fluidized-bed reactor. A portion of the tar, methane, and other light hydrocarbons in the raw gas react with steam and are converted to $\mathrm{CO}$ and $\mathrm{H}_{2}$, while $\mathrm{NH}_{3}$ is decomposed to $\mathrm{N}_{2}$ and $\mathrm{H}_{2}$. Benzene and naphthalene are used to represent the aromatic and polyaromatic $\left(\mathrm{C}_{10}+\right)$ tar components (Spath et al. 2005). The tar reformer is simulated by using an isothermal equilibrium reactor model and the conversion of each compound is simulated by specifying conversion fractions for each reaction. These fractions are listed in Table 2.3 (Spath et al. 2005). The gas enters the tar reformer at the gasifier outlet temperature and exits the reformer at $1383^{\circ} \mathrm{F}$.

Table 2.3. Design Performance of Tar Reformer

\begin{tabular}{lc}
\hline Compounds & Conversion Percentage \\
\hline Methane $\left(\mathrm{CH}_{4}\right)$ & $20 \%$ \\
Ethane $\left(\mathrm{C}_{2} \mathrm{H}_{6}\right)$ & $90 \%$ \\
Ethylene $\left(\mathrm{C}_{2} \mathrm{H}_{4}\right)$ & $50 \%$ \\
Acetylene $\left(\mathrm{C}_{2} \mathrm{H}_{2}\right)$ & $50 \%$ \\
Tars $\left(\mathrm{C}_{10+}\right)$ & $95 \%$ \\
Benzene $\left(\mathrm{C}_{6} \mathrm{H}_{6}\right)$ & $70 \%$ \\
Ammonia $\left(\mathrm{NH}_{3}\right)$ & $70 \%$ \\
& (Converts to $\mathrm{N}_{2}$ and $\left.\mathrm{H}_{2}\right)$ \\
\hline
\end{tabular}

\subsubsection{Water Scrubber/Acid Gas Removal}

After tar and other organic impurities are reduced in the tar cracker, the gas is cooled to $300^{\circ} \mathrm{F}$ using heat exchangers. The gas is then scrubbed and cooled in a venturi scrubber and a spray quench chamber to remove impurities such as particulates, $\mathrm{NH}_{3}$, and other residual tars. Most of the scrubber water is recirculated to the quench sprayers. The purged scrubber water with impurities is sent to a wastewater treatment facility. Because the low concentrations of unconverted tar components preclude condensation, the model assumes that these components pass through the scrubber.

The cooled, scrubbed gas is compressed to 450 psig using a centrifugal compressor. For the indirectly heated gasifier, which operates at near ambient pressure, the compressor consists of five stages with interstage cooling and intercooler temperatures of $140^{\circ} \mathrm{F}$. For each compressor stage, a small amount of water is condensed and collected from the gas in each interstage cooler. The directly heated gasifier operates at 300 psig and only requires a single-stage compressor. Any remaining water in the gas 
exiting the compressor for either system is removed in a knock-out pot. Water collected from the knockout pot (and from the interstage coolers for the indirectly heated gasifier system) is sent to the steam cycle and electric power generation section of the plant.

The pressurized gas contains a large amount of methane and other light hydrocarbons that represent a significant fraction of the total carbon and hydrogen in the biomass feed. Therefore, reforming is performed to convert these compounds to $\mathrm{CO}$ and $\mathrm{H}_{2}$. However, the cleaned gas contains approximately 100 ppmv $\mathrm{H}_{2} \mathrm{~S}$ and lesser amounts of other sulfur compounds (COS, $\mathrm{CS}_{2}$, mercaptans) that will poison reforming catalysts. Therefore, a liquid-phase oxidation (Lo-Cat) process followed by a $\mathrm{ZnO}$ polishing bed is used for sulfur removal. The Lo-Cat process, which is shown in Figure 2.4, removes the bulk of the sulfur (Spath et al. 2005), and is a liquid oxidation process licensed by Merichem (2008).

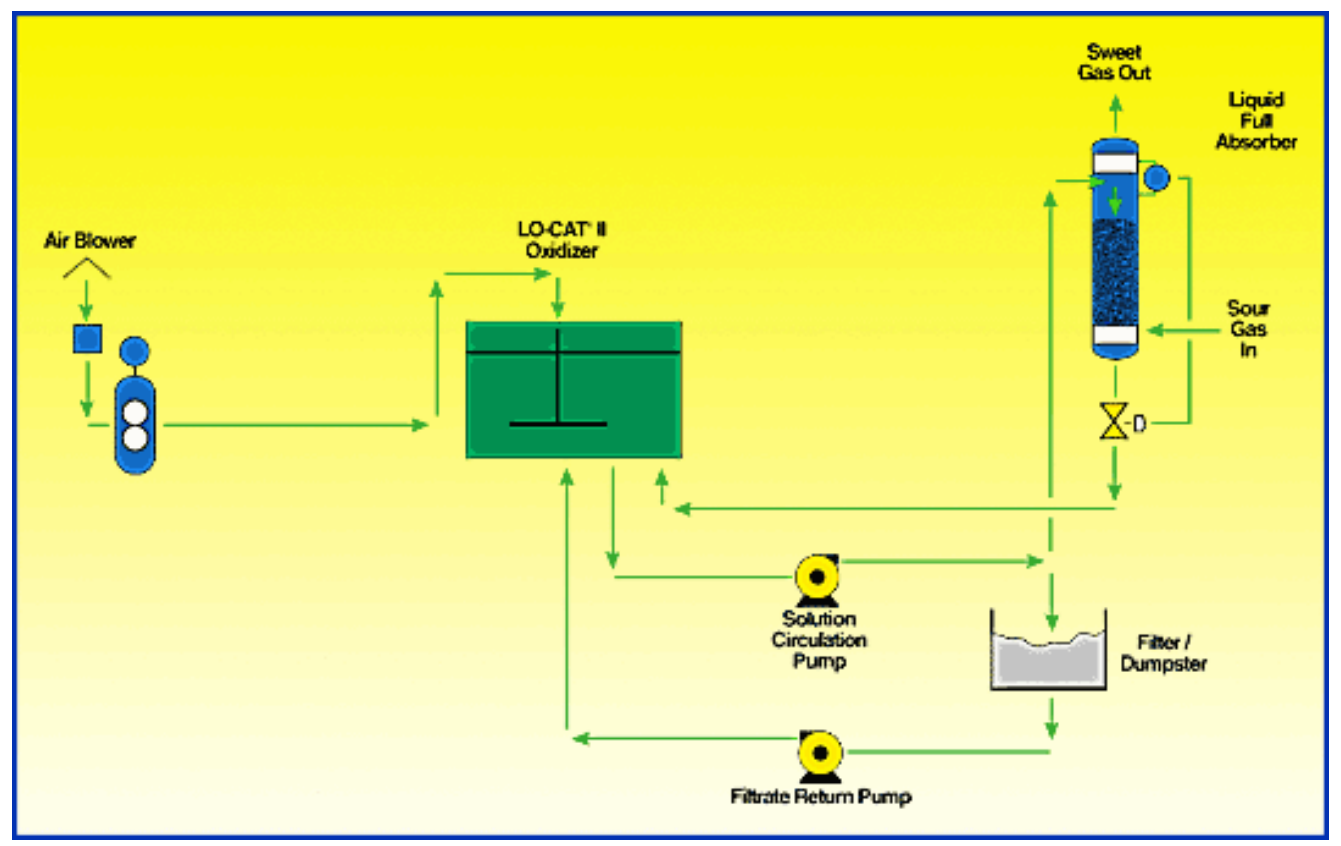

Figure 2.4. Lo-Cat Process (courtesy of the Merichem website, 2008)

The gas is heated to $120^{\circ} \mathrm{F}$, and then sent to the Lo-Cat process where $\mathrm{H}_{2} \mathrm{~S}$ is absorbed and converted to elemental sulfur in an iron chelate-based solution (Ullmann 2006; Merichem 2008). The Lo-Cat

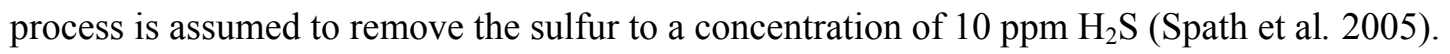

A fixed-bed $\mathrm{ZnO}$ desulfurization unit is used to polish the gas by reducing the sulfur level to less than 1 ppmv (Spath et al. 2005). $\mathrm{H}_{2} \mathrm{~S}$ is captured by the $\mathrm{ZnO}$ sorbent as shown:

$$
\mathrm{ZnO}+\mathrm{H}_{2} \mathrm{~S} \leftrightarrows \mathrm{ZnS}+\mathrm{H}_{2} \mathrm{O}
$$

The $\mathrm{ZnO}$ reactor includes a layer of hydrogenation catalyst, which converts the organic sulfur compounds to $\mathrm{H}_{2} \mathrm{~S}$ and other unsaturated hydrocarbons in the raw gas to saturated hydrocarbons (Ullmann 2006). Gas leaving the hydrogenation stage is heated to $707^{\circ} \mathrm{F}$ using heat from the flue gas exiting the reformer furnace. Spent sorbent is disposed of as waste. Both the Lo-Cat system and the $\mathrm{ZnO}$ system are modeled with component separators. 


\subsubsection{Methane Reforming and Water-Gas Shift Reactor}

Gas leaving the $\mathrm{ZnO}$ bed is sent to a steam reformer to convert the remaining methane, light hydrocarbons, and tar components to additional syngas and to adjust the $\mathrm{H}_{2}$ : $\mathrm{CO}$ ratio via the WGS reaction. The main steam-reformer reactions are:

$$
\begin{gathered}
\mathrm{C}_{\mathrm{n}} \mathrm{H}_{\mathrm{m}}+\mathrm{nH}_{2} \mathrm{O} \leftrightarrows(\mathrm{n}+\mathrm{m} / 2) \mathrm{H}_{2}+\mathrm{nCO} \\
\mathrm{CO}+\mathrm{H}_{2} \mathrm{O} \leftrightarrows \mathrm{CO}_{2}+\mathrm{H}_{2}
\end{gathered}
$$

Before the gas is sent to the steam reformer, it is mixed with high-temperature steam from the steam system. A portion of the $\mathrm{CO}_{2}$ from the amine unit located downstream of the steam reformer may be compressed and added to the gas stream, if needed, to adjust the $\mathrm{H}_{2}$ : $\mathrm{CO}$ ratio. The mixture is sent to the reformer, which consists of tubes filled with nickel catalyst. Heat for the endothermic reforming reaction, which takes place in the temperature range $800^{\circ}$ to $900^{\circ} \mathrm{C}$, is supplied by burning the off-gas from the mixed alcohol synthesis section.

Heat from the hot flue gas in the reformer convection zone is recovered by providing reformer feed preheat and generating high pressure, superheated steam. The reformed syngas passes through several heat exchangers to recover heat by generating high-pressure steam, heating boiler feed water, or heating process steam. The cooled syngas from the reforming process is cooled further by an air cooler to $150^{\circ} \mathrm{F}$ and then trim cooled to $110^{\circ} \mathrm{F}$ with cooling water. The condensed water from syngas is collected and returned to the scrubbing unit.

The steam reformer was modeled using two Gibbs type reactors in CHEMCAD. The heat duty estimated by the Gibbs reactor for the steam-reforming reactions is matched by the duty in the second Gibbs reactor simulating the burners with a bridgewall temperature of $1800^{\circ} \mathrm{F}$.

\subsection{4 $\mathrm{CO}_{2}$ Removal and Compression}

The dry, cool syngas is sent to an amine system to remove $99 \%$ of the $\mathrm{CO}_{2}$. Removing $\mathrm{CO}_{2}$ reduces the volume of syngas, which in turn reduces the downstream equipment sizes and compressor power consumption. In the amine process, $\mathrm{CO}_{2}$ reacts reversibly with the alkaline solvent to form carbamate. A portion of the absorbed $\mathrm{CO}_{2}$ is recovered for use elsewhere in the plant as needed. In the indirectly heated gasifier Base Case, $22 \%$ of the captured $\mathrm{CO}_{2}$ is sent to the reformer to adjust the $\mathrm{H}_{2}: \mathrm{CO}$ ratio. For the directly heated gasifier cases, $\mathrm{CO}_{2}$ is not needed to adjust the $\mathrm{H}_{2}: \mathrm{CO}$ ratio. However, because of the high-pressure gasification operation, some recycle $\mathrm{CO}_{2}$ is compressed and used to pressurize the lock hopper and pneumatically convey and feed the dry wood into the gasifier.

The treated syngas is sent to a multiple-stage, intercooled compressor and compressed from 413 to $2000 \mathrm{psi}$. This is simulated by using a three-stage reciprocating compressor with an isentropic efficiency of $78 \%$ and an intercooler temperature of $140^{\circ} \mathrm{F}$.

\subsubsection{Heat Recovery}

The heat recovery in the gas purification and compression section uses the heat from the hot syngas leaving the reformer and the flue gas from reformer furnace. For the indirectly-heated gasifier cases, the 
hot reformed syngas at $1650^{\circ} \mathrm{F}$ is first used to superheat the high-pressure saturated steam at (1265 psi) to $1000^{\circ} \mathrm{F}$, which is sent to the steam turbine. The syngas leaving the reformer is cooled in a heat exchanger that superheats intermediate-pressure saturated steam (450 psi) from the mixed alcohol synthesis reactor to $720^{\circ} \mathrm{F}$, which is sent to the intermediate stage of the steam turbine. Finally, the partially cooled syngas is sent to the third heat exchanger to heat the boiler feed water to generate saturated steam at $575^{\circ} \mathrm{F}$ and $1280 \mathrm{psi}$. The syngas is cooled to $250^{\circ} \mathrm{F}$ before being sent to an air cooler. The hot flue gas exiting the reformer furnace is first used for preheating the inlet syngas to the reformer. Then, the flue gas at $1450^{\circ} \mathrm{F}$ superheats the saturated steam at $1265 \mathrm{psi}$ to $1000^{\circ} \mathrm{F}$. Finally, the flue gas passes through two heat exchangers where it provides feed preheat for the Lo-Cat and $\mathrm{ZnO}$ processes.

The heat recovery section for the directly heated gasifier cases is similar to that of the indirectlyheated gasifier system except that the hot flue gas from the reformer furnace is used to generate superheated steam first before preheating the inlet syngas. The reason for this difference is that the inlet syngas flow rate is much greater for the directly heated gasifier than that of the indirectly-heated gasifier. If the flue gas is first used to preheat the inlet gas, the temperature is too low to be used to generate superheated steam.

\subsection{Alcohol Synthesis and Product Recovery Model}

Figure 2.5 shows the mixed alcohol synthesis process. Syngas is converted into an ethanol-rich mixed alcohol product in an alcohol synthesis reactor followed by product gas/liquid separation using a series of flash vessels and a stabilization column to degas the liquid product. The liquid product is dewatered using a molecular sieve column and further purified in a series of distillation units to recover methanol, ethanol, propanol, butanol, and pentanol. This section is the same for both the indirectly heated and the directly heated gasifier cases.

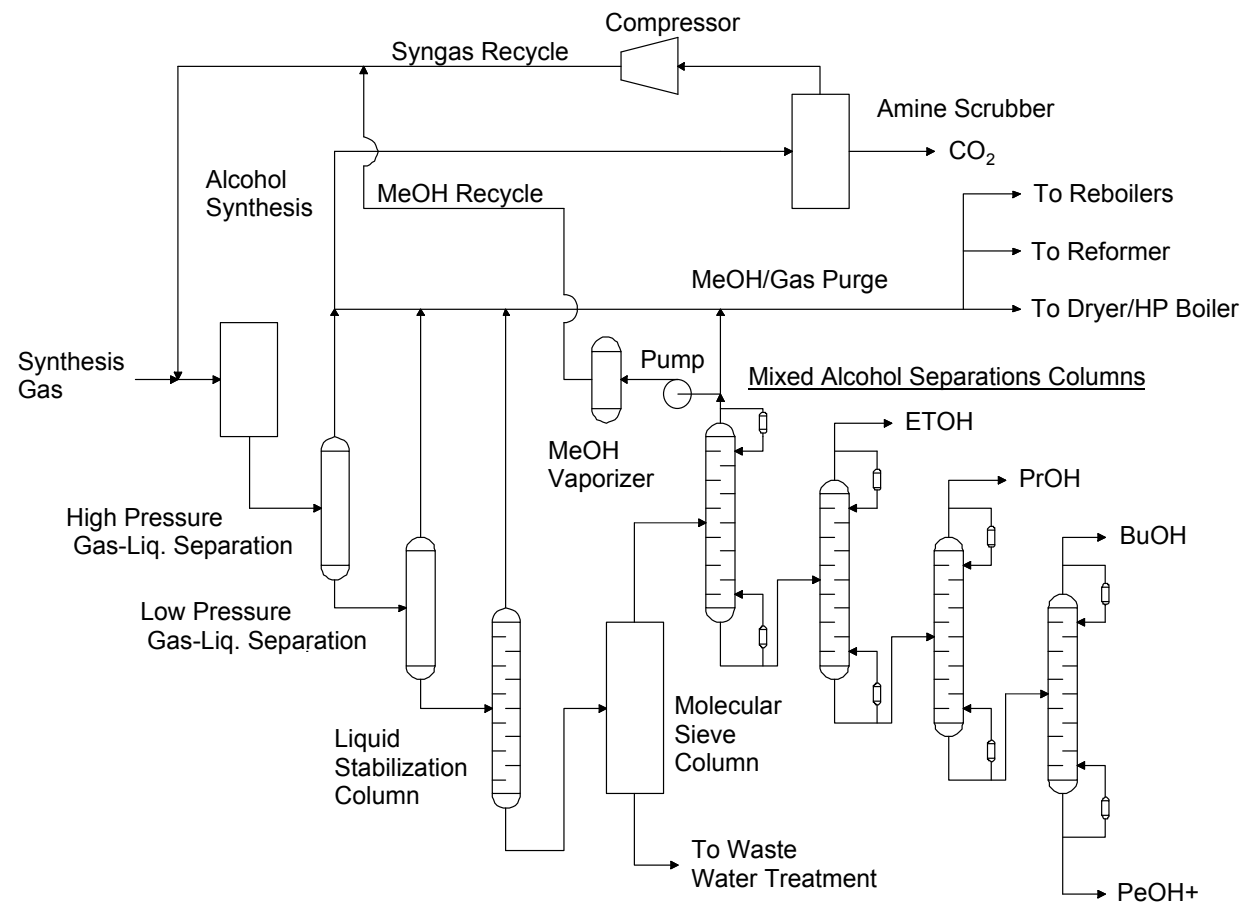

Figure 2.5. Mixed Alcohol Synthesis and Purification Section 


\subsubsection{Alcohol Synthesis Reactor}

Mixed alcohol synthesis involves the reaction between $\mathrm{CO}$ and $\mathrm{H}_{2}$ under high pressures (800 to $2500 \mathrm{psig})$ and moderate temperatures $\left(180\right.$ to $\left.350^{\circ} \mathrm{C}\right)$ to produce a mixture of $\mathrm{C}_{1}$ to $\mathrm{C}_{6}$ mono-alcohols. In addition, hydrocarbon gases, liquids, and even solids (waxes) may be produced as byproducts, depending on the catalyst chosen and the reaction conditions. In addition, some mixed alcohol synthesis catalysts also catalyze the WGS reaction, resulting in the conversion of a significant portion of the CO to $\mathrm{CO}_{2}$.

Mixed alcohol synthesis involves multiple reactions with different pathways to various alcohols and hydrocarbons. The overall stoichiometric reaction for higher alcohol synthesis is (Hutchings et al. 1988; Wong et al. 1986):

$$
\mathrm{nCO}+2 \mathrm{nH}_{2} \rightarrow \mathrm{C}_{\mathrm{n}} \mathrm{H}_{2 \mathrm{n}+1} \mathrm{OH}+(\mathrm{n}-1) \mathrm{H}_{2} \mathrm{O}
$$

with the value of " $n$ " typically ranging from 1 to 6 . Hydrocarbon synthesis takes place according to a similar reaction scheme:

$$
\begin{gathered}
\mathrm{nCO}+(2 \mathrm{n}+1) \mathrm{H}_{2} \rightarrow \mathrm{C}_{\mathrm{n}} \mathrm{H}_{2 \mathrm{n}+2}+\mathrm{nH}_{2} \mathrm{O} \\
\text { or } \\
\mathrm{nCO}+(2 \mathrm{n}) \mathrm{H}_{2} \rightarrow \mathrm{C}_{\mathrm{n}} \mathrm{H}_{2 \mathrm{n}}+\mathrm{nH}_{2} \mathrm{O}
\end{gathered}
$$

The distribution of hydrocarbons generally follows the Anderson-Schulz-Flory Distribution that is typical for FT synthesis. While the stoichiometry of these reactions suggests an optimum $\mathrm{H}_{2} / \mathrm{CO}$ ratio of approximately 2.0, the optimal ratio is closer to 1.0 if the catalyst is significantly active for the WGS reaction (Equation 2.3).

This study assumes a modified FT catalyst $\left(\mathrm{K} / \mathrm{Co} / \mathrm{MoS}_{2}\right.$ catalyst) because of its relatively high alcohol selectivity and its main product mixture of linear alcohols. It also is capable of converting recycled methanol to higher alcohols, thereby achieving an overall high selectivity to $\mathrm{C}_{2}+$ alcohols. A description of this model can be found in Aden et al. (2005), which draws on several literature sources (Forzatti et al.1991; Herman 1991; Courty et al. 1990; Quarderer 1986).

Table 2.4 summarizes the synthesis reactor design assumptions. Clean syngas at $2000 \mathrm{psi}$ is preheated to $570^{\circ} \mathrm{F}\left(299^{\circ} \mathrm{C}\right)$ in a feed-product exchanger. The mixed-alcohol reactor is assumed to be a fixed-bed tubular design with steam produced in the shell. The product gas is partially cooled by the inlet compressed syngas, followed by further cooling to condense the alcohols and water. Most of the unconverted syngas is recycled. Ninety percent of the methanol product also is recycled to the reactor to increase the conversion efficiency. The liquid alcohols are then sent to the alcohol-separation and purification processes. The methanol purge stream and the product-gas purge stream are combined and sent to the steam-cycle and power-generation section of the plant for power generation.

The mixed alcohol synthesis reactions are exothermic and release a large amount of heat that is removed from the reactor by vaporizing boiler feed water on the shell side of the reactor. Approximately $2.5 \mathrm{lb}$ of $450 \mathrm{psi}$ steam/lb of ethanol is produced. The medium pressure steam is superheated by the syngas leaving the reformer in the Gas Purification and Conditioning Section and then used to drive the mediumpressure steam turbine in the steam Cycle and Power Recovery Section for electric power generation. 
Table 2.4. Design Assumptions for Mixed Alcohol Synthesis

\begin{tabular}{lc}
\hline Catalyst & Modified FT \\
Temperature $\left({ }^{\circ} \mathrm{F}\right)$ & 570 \\
Pressure (psia) & 2000 \\
Reactor Design & Fixed Bed \\
$\mathrm{H}_{2} /$ CO Ratio & 1.2 \\
$\mathrm{CO}_{2}$ inlet concentration & $0.2 \mathrm{~mol} \%$ \\
Gas hourly space velocity, L/Lcat/hr & 3000 \\
\hline
\end{tabular}

The reactor is simulated in CHEMCAD with a stoichiometric reactor model. Table 2.5 shows the main reactions modeled involving $\mathrm{CO}$ and recycled methanol. The specific conversions of $\mathrm{CO}$ and recycled methanol, also shown in the table for each of the main reactions, are set to reach catalyst performance targets that are consistent with those reported by Aden et al. (2005). Note that the methanol conversion equations apply only to recycled methanol and not to the methanol produced by the main $\mathrm{CO} / \mathrm{H}_{2}$ reactions in reaction 4 .

Table 2.5. Reaction Stoichiometry and Base-Case Reactant Conversions for Mixed Alcohol Synthesis

\begin{tabular}{|c|c|c|}
\hline $\begin{array}{c}\text { Reaction } \\
\text { No. } \\
\end{array}$ & & $\begin{array}{l}\text { Mol\% CO Conversion } \\
\text { (per pass): }\end{array}$ \\
\hline 1 & $\mathrm{CO}+\mathrm{H}_{2} \mathrm{O} \rightarrow \mathrm{CO}_{2}+\mathrm{H}_{2}$ & $13.0 \%$ \\
\hline 2 & $\mathrm{CO}+3 \mathrm{H}_{2} \rightarrow \mathrm{CH}_{4}+\mathrm{H}_{2} \mathrm{O}$ & $4.5 \%$ \\
\hline 3 & $2 \mathrm{CO}+4 \mathrm{H}_{2} \rightarrow \mathrm{C}_{2} \mathrm{H}_{6}+\mathrm{H}_{2} \mathrm{O}$ & $0.5 \%$ \\
\hline 4 & $\mathrm{CO}+\mathrm{H}_{2} \rightarrow$ Methanol & $4.1 \%$ \\
\hline 5 & $2 \mathrm{CO}+4 \mathrm{H}_{2} \rightarrow$ Ethanol $+\mathrm{H}_{2} \mathrm{O}$ & $11.4 \%$ \\
\hline 6 & $3 \mathrm{CO}+6 \mathrm{H}_{2} \rightarrow$ Propanol $+2 \mathrm{H}_{2} \mathrm{O}$ & $3.0 \%$ \\
\hline 7 & $4 \mathrm{CO}+8 \mathrm{H}_{2} \rightarrow \mathrm{n}-\mathrm{Butanol}+3 \mathrm{H}_{2} \mathrm{O}$ & $1.0 \%$ \\
\hline \multirow[t]{2}{*}{8} & $5 \mathrm{CO}+10 \mathrm{H}_{2} \rightarrow$ n-Pentanol $+4 \mathrm{H}_{2} \mathrm{O}$ & $0.5 \%$ \\
\hline & Total CO Conversion & $38 \%$ \\
\hline \multicolumn{2}{|l|}{ Reaction } & Mole \% Recycled Methanol \\
\hline No. & Reaction & Conversion (per pass): \\
\hline 9 & Methanol $+\mathrm{CO}+2 \mathrm{H}_{2} \rightarrow$ ethanol $+\mathrm{H}_{2} \mathrm{O}$ & $58 \%$ \\
\hline 10 & Methanol $+2 \mathrm{CO}+4 \mathrm{H}_{2} \rightarrow$ Propanol $+2 \mathrm{H}_{2} \mathrm{O}$ & $7 \%$ \\
\hline 11 & Methanol $+3 \mathrm{CO}+6 \mathrm{H}_{2} \rightarrow$ n-Butanol $+3 \mathrm{H}_{2} \mathrm{O}$ & $4.5 \%$ \\
\hline \multirow[t]{2}{*}{12} & Methanol $+4 \mathrm{CO}+8 \mathrm{H}_{2} \rightarrow$ n-Pentanol $+4 \mathrm{H}_{2} \mathrm{O}$ & $2 \%$ \\
\hline & Total Recycled Methanol Conversion & $71.5 \%$ \\
\hline
\end{tabular}

\subsubsection{Product Gas Recycle}

The product gas leaves the alcohol-synthesis reactor at $570^{\circ} \mathrm{F}\left(299^{\circ} \mathrm{C}\right)$ and is cooled by heat exchange with the reactor feed syngas to $300^{\circ} \mathrm{F}\left(149^{\circ} \mathrm{C}\right)$. The gas is further cooled in an air-fin exchanger to $150^{\circ} \mathrm{F}$ $\left(66^{\circ} \mathrm{C}\right)$ and then trim cooled to $110^{\circ} \mathrm{F}\left(43^{\circ} \mathrm{C}\right)$ using cooling water. Condensed alcohols and water are separated from the gas in high- and low-pressure flash drums. The liquid stream is sent to the purification processes. The high-pressure gas stream containing $\mathrm{H}_{2}, \mathrm{CO}, \mathrm{CH}_{4}$, and $\mathrm{CO}_{2}$, is passed through a highpressure amine system to remove $\mathrm{CO}_{2}$ from the gas stream and then recycled to the inlet of the alcoholsynthesis reactor. The low-pressure off-gas is sent to the fuel-gas system. 
In the indirectly heated gasifier systems, $98 \%$ of the treated product gas is recycled, and the remainder purged from the system to limit the build-up of methane in the syngas entering the alcoholsynthesis reactor. A portion of the $2 \%$ purge gas is sent to the steam reformer as fuel for the burner. The remaining portion of the purge gas is sent to the boiler in the steam cycle for power generation and to the distillation columns that require fired re-boilers.

In the directly heated gasifier system, $96 \%$ of the unconverted product gas is recycled. A lower recycle rate is required because more fuel gas is needed to fire the steam reformer than that required by the indirectly heated gasifier system. A portion of the purge gas is used in the biomass feed dryer, and a portion is sent to the distillation columns that require fired re-boilers.

\subsubsection{Liquid Separation and Purification}

The crude liquid product stream from the gas/liquid separators is sent to a stabilization column to remove the non-condensable gases, and the gases are sent to the fuel-gas system. The liquid product leaving the stabilization column is vaporized and sent to molecular sieve drying columns, where it is assumed that all the water is removed. The dried product stream is condensed and then sent to a distillation column, where $99 \%$ of the methanol is recovered overhead at purity greater than $99 \%$. The bottoms product from the methanol column is sent to a second distillation column where $99.95 \%$ of incoming ethanol is recovered in the overhead stream and $99 \%$ of the propanol is recovered in the bottom stream along with the higher alcohols. The bottom stream is sent to two distillation towers where propanol and butanol are recovered in the two towers. The bottom stream from the final distillation column mainly contains higher mixed alcohols. The CHEMCAD SCDS rigorous distillation column unit operation is used to model each distillation column.

\subsubsection{Methanol Byproduct Recycle}

Ninety percent of the methanol stream from the methanol column is recycled to the mixed-synthesis reactor to where it is further converted to higher alcohols (mainly ethanol). The remaining methanol stream is used as fuel.

\subsection{Steam-Cycle and Power-Generation Model}

The Steam and Power Generation Area generates power and process steam using extraction steam turbines. High-pressure steam is recovered from the gas-cooling sections of the gasifier and steam reformer. Medium-pressure steam is generated by cooling the mixed-alcohol reactor. The main differences in the steam systems for the indirectly heated and directly heated gasifier systems (shown in Figures 2.6 and 2.7) are the sources of high-pressure steam, and the disposition of medium- and lowpressure steam. The indirectly heated gasifier system produces more fuel gas than needed by the steam reformer and distillation tower re-boilers. Hence, the steam system includes a separate boiler and gas turbine where excess fuel gas is burned to generate high-pressure steam in a boiler for use in the steam turbines.

High-pressure saturated steam generated by heat recovery in the gasifier and steam reformer sections, or by a separate boiler in the indirectly heated gasifier cases, is superheated and sent to a high-pressure steam turbine to produce electricity. Medium-pressure steam leaving the high-pressure steam turbine is 


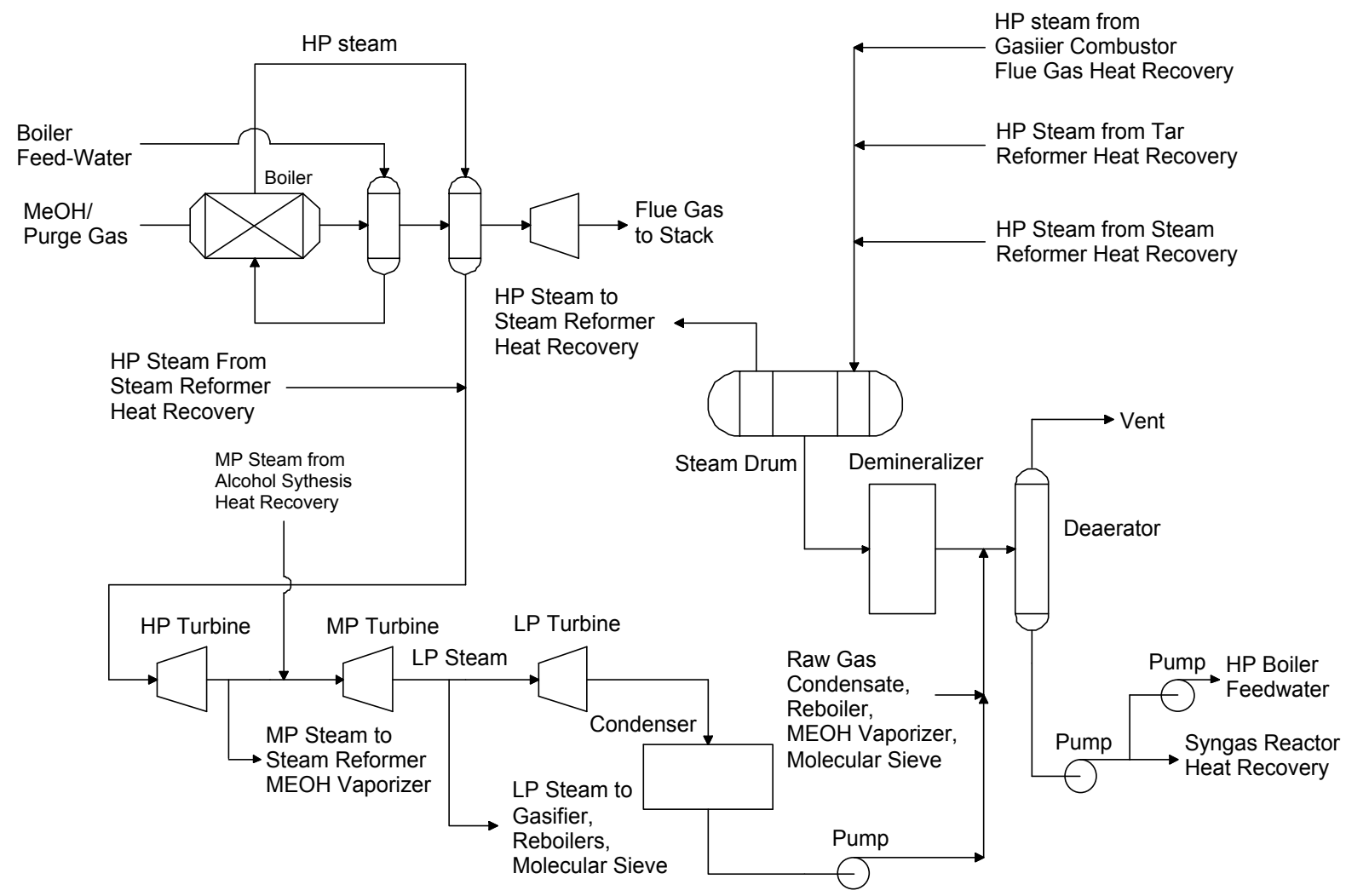

Figure 2.6. Steam and Power Generation Section for the Process Using and Indirectly Heated Gasifier

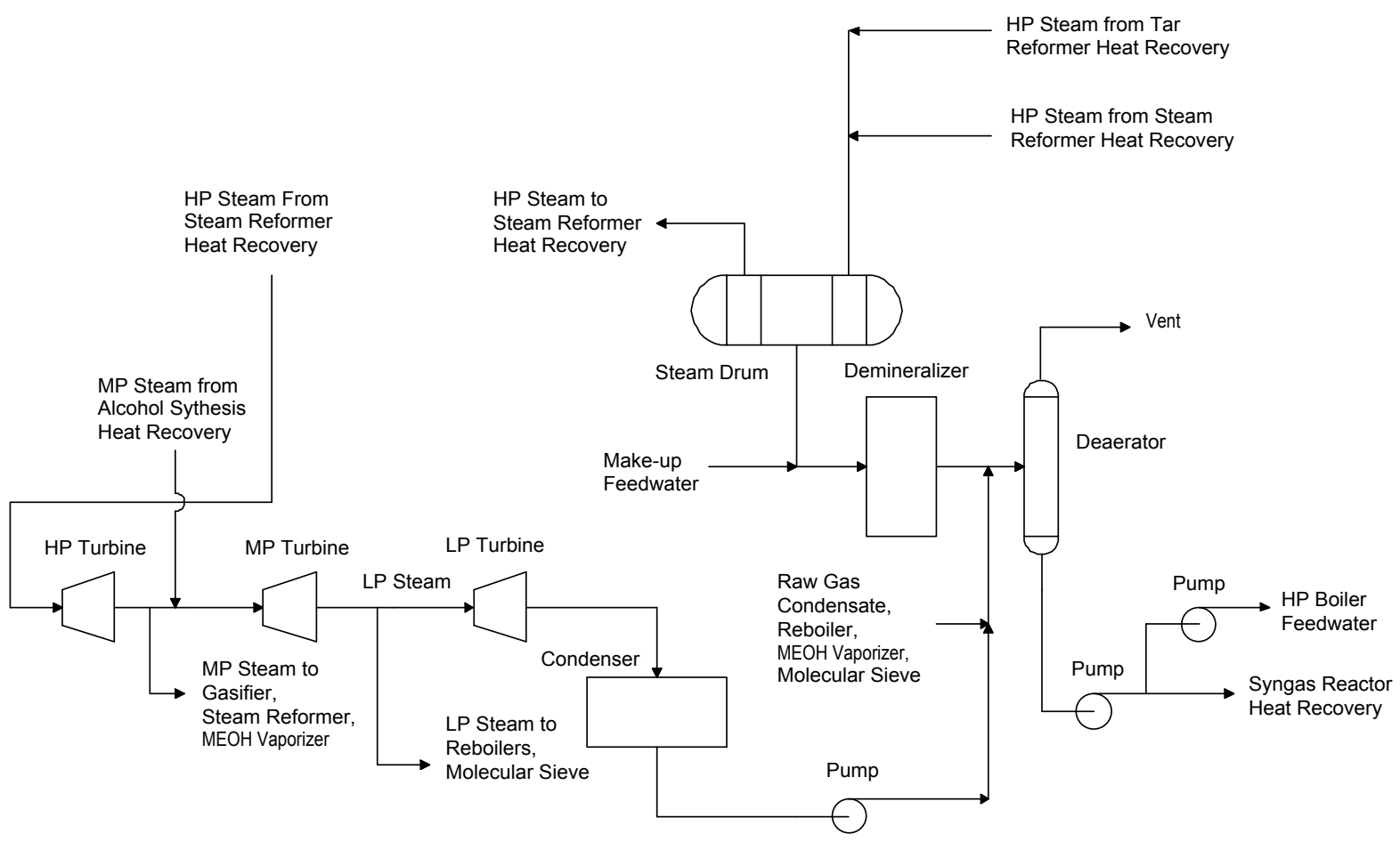

Figure 2.7. Steam and Power Generation Section for the Process Using a Directly Heated Gasifier 
combined with medium-pressure steam recovered from the alcohol-synthesis reactor and passed through a second medium-pressure steam turbine to produce electricity. Medium-pressure steam is extracted from the turbine and sent to the steam reformer and methanol vaporizer for both systems. Low-pressure steam leaving the medium-pressure steam turbine is extracted to provide heat to the molecular sieve column and some of the distillation columns for both systems. Medium-pressure steam is used in the directly heated gasifier, while the indirectly heated gasifier uses low-pressure steam. Steam leaving the lowest pressure turbine stage is condensed and returned to the de-aerator along with condensate from process heaters.

\subsection{Overall Process Modeling and Cost Estimation Methodology}

Process modeling was performed using the CHEMCAD software program. CHEMCAD software includes energy and material-balance models for most unit operations in the system including compressors, boilers, steam generators, heat exchangers, and distillation columns. Special processes such as the gasifiers, tar crackers, and ethanol-synthesis reactors were modeled in Excel spreadsheets using available experimental data. These process models are discussed in more detail in Appendix A.

The modeling results produce inlet and outlet process flow-rate and compositional information for each unit operation based on key operating parameters, such as pressure and temperature as well as any energy consumed or produced by the process where applicable. This information was used to size equipment and develop operating costs for the plant. The Base Cases for both types of gasifiers represent what is believed to be the current state-of-the-art for the various unit operations. It is understood that there are other technology choices for some of the unit operations including reforming, acid-gas removal, and alcohol synthesis and product recovery.

The equipment costs assume that this is the " $\mathrm{n}$ "th" plant; that is, all research and development required to commercialize the process at the given scale is complete, and the manufacturing processes are mature and the equipment readily available.

The equipment costs were estimated by scaling the Basis-Case equipment costs by the appropriate metric (e.g., flow, duty, etc.) and applying an appropriate scaling factor:

$$
(\text { Cost } \$)=(\text { Base Cost } \$)^{*}[(\text { Capacity }) /(\text { Base Capacity })]^{(\text {scaling factor })}
$$

Appendix B summarizes the cost bases and scaling exponents for specific equipment identified for each process along with the number of units of each piece of equipment needed for each unit operation.

Most of the base equipment costs for the feed-preparation, gas-purification and conditioning, and steam-cycle and power-generation sections of the plant were obtained from Spath et al. (2005). The Spath et al. report is an economic analysis of hydrogen production from biomass using an indirectly heated gasifier. Gasifier costs for both types of gasifiers were obtained from Hammelinck et al. (2001). The ASPEN Icarus costing program was used to cost most of the equipment in the alcohol synthesis and purification section of the plant and to select equipment within the gasification and gas purification and conditioning sections. Specialized equipment, such as the two gasifier systems, tar reformer, amine scrubber systems, molecular sieve alcohol dryer, and air separation unit, were costed using other reference sources. Table B.1 summarizes the costing sources, cost bases, and scaling exponents for specific equipment identified for each process, along with the number of units of each piece of equipment needed for each unit operation. 
All capital costs are reported in first quarter (1stQ) 2007 dollars. The Chemical Engineering Plant Cost Index (CEPCI) was used to escalate equipment costs (Chemical Engineering Magazine 2006a, b, c):

$$
\text { Cost in 1stQ } 2007=\text { Base Year Cost * (1stQ } 2007 \text { CEPCI)/(Base Year CEPCI) }
$$

Table B.1 in the Appendix B also provides the basis year for each piece of equipment in addition to the basis year cost. Installed equipment costs were calculated by multiplying the equipment cost by the installation factor also shown for each piece of equipment in Table B.1.

The total capital investment is factored from installed equipment costs. The factors are shown in Table 2.6 (Peters and Timmerhaus 2003) excluding the service facilities. Service facilities (i.e., support systems that are usually associated with the outside battery limits) are included in the detailed equipment list.

Table 2.6. Total Project Investment for the Design Case Standalone Plant

\begin{tabular}{lrl}
\hline Total Purchased Equipment Cost (TPEC) & $100 \%$ & \\
Purchased Equipment Installation & $39 \%$ & of TPEC \\
Instrumentation and Controls & $26 \%$ & of TPEC \\
Piping & $31 \%$ & of TPEC \\
Electrical Systems & $10 \%$ & of TPEC \\
Buildings (including services) & $29 \%$ & of TPEC \\
Yard Improvements & $12 \%$ & of TPEC \\
Service Facilities (installed) & $0 \%$ & of TPEC \\
Total Installed Cost (TIC) & $247 \%$ & \\
Indirect Costs & & \\
Engineering & $32 \%$ & of TPEC \\
Construction & $34 \%$ & of TPEC \\
Legal and Contractors Fees & $23 \%$ & of TPEC \\
Project Contingency & $37 \%$ & of TPEC \\
Total Indirect & $126 \%$ & \\
Total Capital Investment (TCI) & $373 \%$ & \\
\hline
\end{tabular}

Production cost assumptions are listed in Table 2.7. An annualized product value is a simple, yet convenient, way to compare differences between processing options while capturing the effects of changes in capital and operating costs. Table 2.7 shows the assumptions used to arrive at the annualized product value and assumes no time value of money. Working capital, start-up costs, interest, and income taxes are excluded. The pre-tax product value is calculated as:

$$
\text { Product value }=\text { Variable Costs }+ \text { Fixed Costs }+ \text { Depreciation }+ \text { G\&A Costs }+ \text { ROI }
$$


Table 2.7. Economic Assumptions

\begin{tabular}{|c|c|c|}
\hline Raw Materials & Value & Reference \\
\hline Hybrid Poplar Chips, \$/dry short ton & 35 & Phillips et al 2007 \\
\hline Ash Disposal, \$/short ton & 18 & Phillips et al 2007 \\
\hline Olivine, $\$$ short ton & 179.2 & Phillips et al 2007 \\
\hline Misc. Chemicals, \$/gal ethanol & 5 & Estimated from Phillips et al 2007 \\
\hline Tar Reformer Catalyst, \$/gal ethanol & 5 & Estimated from Phillips et al 2007 \\
\hline Mixed Alcohol Catalyst, $\$ / 1 \mathrm{~b}$ catalyst & 50 & assumption \\
\hline \multicolumn{3}{|l|}{ Utilities } \\
\hline Natural Gas, $\$ / 1000$ scf (1000 BTU/scf) & 8.47 & EIA \\
\hline Electricity, $\phi / \mathrm{kwh}$ & 6.75 & EIA \\
\hline Cooling Water, $\varnothing / 1000$ gallons & 6 & Wang 2003 \\
\hline Waste water treatment, $\$ / 100 \mathrm{ft}^{3}$ & 2.28 & (EBMUD.com, BCC 2600) \\
\hline Stream Factor & $90 \%$ & assumption \\
\hline Construction & Overnight $^{(a)}$ & assumption \\
\hline Plant life, yrs & 20 & Phillips et al 2007 \\
\hline Straight Line Depreciation, yrs & 20 & assumption \\
\hline Rate of return on capital, \% & $10 \%$ of capital investment & Phillips et al 2007 \\
\hline \multicolumn{3}{|l|}{ Labor } \\
\hline $\begin{array}{l}\text { Operating labor, } \$ / \mathrm{hr} \text { burdened \& } 10 \% \text { shift } \\
\text { overlap }\end{array}$ & 37.66 & Wang 2003 \\
\hline Maintenance labor & $0.9 \%$ of TIC & Wang 2003 \\
\hline Control Lab labor & $20 \%$ of operating labor & Wang 2003 \\
\hline Operator per shift per major unit & 1 & estimated \\
\hline \multicolumn{3}{|l|}{ Materials } \\
\hline Maintenance & $0.6 \%$ of $\mathrm{TIC}$ & Wang 2003 \\
\hline Operating Supplies & $10 \%$ of operating labor & Wang 2003 \\
\hline Overhead & $80 \%$ of total labor & Wang 2003 \\
\hline Local taxes \& insurance & $2 \%$ of total fixed capital & Wang 2003 \\
\hline General \& administrative, sales and research & $5 \%$ of product value & Wang 2003 \\
\hline
\end{tabular}




\subsection{Results and Analysis}

This chapter describes the results of modeling and cost analyses for the base and alternative scenario cases for both gasifier configurations. The selected parameters for the scenario analysis include gasification temperature, pressure, tar production, and the $\mathrm{H}_{2}: \mathrm{CO}$ ratio of the raw product gas from the gasifier. The alternative scenario analyses examine how changes to the Base Case assumptions affect processing costs, and identifies which assumptions have significant impact and where there are important gaps in the current technology.

\subsection{Indirectly Heated Gasifier Scenarios}

Seven cases are considered for the mixed alcohols synthesis plant with syngas produced by an indirectly heated gasifier:

Base Case: The gasifier syngas composition is based on correlations developed by Spath et al. (2005) for an indirectly heated gasifier. The balance-of-plant processing assumptions and unit-operation configurations are similar to those used by Spath et al. (2005) and Aden et al. (2005).

Case A1: The gasifier raw syngas composition has a $\mathrm{H}_{2}: \mathrm{CO}$ ratio that is close to 2:1 versus approximately 0.5 for the Base Case.

Case A2: $\quad$ The gasification pressure is increased to $147 \mathrm{psi}(10 \mathrm{~atm})$ compared to $23 \mathrm{psig}$ for the base case. Because the gasifier model does not include a pressure factor, the syngas composition is assumed to be the same as that predicted at atmospheric pressure.

Case A3: The steam reformer is replaced by a simple shift reactor. Methane and ethane are assumed to be inert in the synthesis step. The total syngas pressure is increased to maintain the same $\mathrm{H}_{2}$ and $\mathrm{CO}$ partial pressures as in the Base Case.

Case A4: The same assumptions as in Case A3 apply, except that the total syngas pressure is unchanged from the Base Case.

Case A5: $\quad$ The tar production rate is double that of the Base Case.

Case A6: $\quad$ The tar production rate is half that of the Base Case.

Table 3.1 summarizes the operating conditions and performance results for each case, while Table 3.2 and Table 3.3 list the associated costs.

\subsubsection{Base Case}

The indirectly heated gasifier Base Case used the process configurations shown in Figures 2.1, 2.3, 2.4, 2.5 and 2.6. The following key operating parameters for the gasifier and alcohol synthesis reactor shown in Table 3.1 are similar to those used by Aden et al. (2005):

- Gasifier Pressure - 23 psig

- Gasifier Temperature $-1598^{\circ} \mathrm{C}$

- Alcohol synthesis Reactor Temperature $-300^{\circ} \mathrm{C}$

- Alcohol Synthesis Reactor Pressure - 2000 psig

- Alcohol Synthesis Reactor Feed-Gas $\mathrm{H}_{2}$ :CO ratio - 1.2. 
Table 3.1. Performance Results for Indirectly Heated Gasifier Based System Models

\begin{tabular}{|c|c|c|c|c|c|c|c|}
\hline Case & Base & A1 & A2 & A3 & A4 & A5 & A6 \\
\hline Case Description & Base & $\begin{array}{c}1.7: 1.0 \\
\mathrm{H}_{2}: \mathrm{CO} \\
\text { Ratio }\end{array}$ & $\begin{array}{c}\text { Increased } \\
\text { Gasifier } \\
\text { Pressure }\end{array}$ & $\begin{array}{l}\text { No Steam } \\
\text { Reformer } \\
\text { Const. } \mathrm{H}_{2} \text {, } \\
\mathrm{CO} \text { partial } \\
\text { Pressures }\end{array}$ & $\begin{array}{c}\text { No Steam } \\
\text { Reformer } \\
\text { Constant } \\
\text { Total } \\
\text { Pressure }\end{array}$ & $\begin{array}{l}\text { Double } \\
\text { Tar Conc. }\end{array}$ & $\begin{array}{l}\text { One-Half } \\
\text { Tar Conc. }\end{array}$ \\
\hline Gasifier Pressure, psi & 23 & 14.7 & 147 & 23 & 23 & 23 & 23 \\
\hline Gasifier Temperature, ${ }^{\circ} \mathrm{F}$ & 1598 & 1652 & 1598 & 1598 & 1598 & 1598 & 1598 \\
\hline \multicolumn{8}{|l|}{ Raw Gas Compositions, Mol\% } \\
\hline Hydrogen & 12.9 & 19.2 & 12.7 & 12.9 & 12.9 & 12.7 & 12.9 \\
\hline Carbon monoxide & 22.8 & 11.1 & 22.5 & 22.8 & 22.8 & 22.5 & 22.9 \\
\hline Carbon dioxide & 6.9 & 11.1 & 8 & 6.9 & 6.9 & 6.8 & 6.9 \\
\hline Methane & 8.3 & 4.8 & 8.2 & 8.3 & 8.3 & 8.2 & 8.3 \\
\hline Water & 45.6 & 52.2 & 45 & 45.6 & 45.6 & 45.9 & 45.4 \\
\hline Benzene & 0.07 & 0.05 & 0.07 & 0.07 & 0.07 & 0.14 & 0.03 \\
\hline Naphthalene & 0.13 & 0.1 & 0.12 & 0.13 & 0.13 & 0.25 & 0.06 \\
\hline $\mathrm{C}_{2}+$ & 2.7 & 1 & 2.7 & 2.7 & 2.7 & 2.7 & 2.7 \\
\hline $\mathrm{H}_{2}: \mathrm{CO}$ ratio & 0.57 & 1.74 & 0.57 & 0.57 & 0.57 & 0.57 & 0.57 \\
\hline Char Production, lbmole/hr & 33970 & 42660 & 33970 & 33970 & 33970 & 33970 & 33970 \\
\hline $\begin{array}{l}\text { Scrubbed (dry) raw gas flow rate, } \\
\text { lbmol/hr }\end{array}$ & 8438 & 9068 & 8568 & 8438 & 8438 & 8699 & 8267 \\
\hline Alcohol synthesis Pressure, psi & 1995 & 1995 & 1995 & 2091 & 1995 & 1995 & 1995 \\
\hline Alcohol Synthesis Temperature, ${ }^{\circ} \mathrm{F}$ & 570 & 570 & 570 & 570 & 570 & 570 & 570 \\
\hline \multicolumn{8}{|l|}{ Clean syngas composition, mol\% } \\
\hline Nitrogen & 0.4 & 0.4 & 0.3 & 0.4 & 0.4 & 0.4 & 0.4 \\
\hline Hydrogen & 49.4 & 51.4 & 49.5 & 47.2 & 47.2 & 49.1 & 49.1 \\
\hline Carbon monoxide & 41.6 & 43.7 & 42.1 & 39.7 & 39.7 & 41.6 & 41.9 \\
\hline Carbon dioxide & 0.2 & 0.3 & 0.2 & 0.2 & 0.2 & 0.2 & 0.2 \\
\hline Methane & 8.4 & 4.2 & 7.9 & 10.4 & 10.4 & 8.7 & 8.4 \\
\hline Water & 0 & 0 & 0 & 0 & 0 & 0 & 0 \\
\hline $\mathrm{C}_{2}+$ & 0 & 0 & 0 & 2.1 & 2.1 & 0 & 0 \\
\hline $\mathrm{H}_{2}: \mathrm{CO}$ ratio & 1.19 & 1.18 & 1.18 & 1.19 & 1.19 & 1.18 & 1.17 \\
\hline Clean Syngas Flowrate, $1 \mathrm{bmol} / \mathrm{hr}$ & 8645 & 8247 & 8734 & 7656 & 7656 & 8798 & 8517 \\
\hline \multicolumn{8}{|l|}{ Final Products, $\mathrm{MM}$ gal/yr } \\
\hline Ethanol & 37.6 & 37.7 & 38.5 & 31.7 & 31.8 & 38.3 & 37.3 \\
\hline Propanol & 7.6 & 7.6 & 7.8 & 6.4 & 6.4 & 7.7 & 7.5 \\
\hline Butanol & 3.3 & 3.3 & 3.3 & 2.8 & 2.8 & 3.3 & 3.2 \\
\hline Pentanol & 1.6 & 1.6 & 1.7 & 1.4 & 1.4 & 1.7 & 1.6 \\
\hline Total & 50.1 & 50.2 & 51.3 & 42.3 & 42.3 & 51 & 49.7 \\
\hline Carbon Efficiency, \% & 25 & 25 & 25.6 & 21.1 & 21.1 & 25.5 & 24.8 \\
\hline \multicolumn{8}{|l|}{ Power Consumption, MW } \\
\hline Lock hopper gas compressor & 0 & 0 & -0.1 & 0 & 0 & 0 & 0 \\
\hline Air compressor & -4.8 & -6.1 & -16.9 & -4.7 & -4.7 & -4.7 & -4.7 \\
\hline Raw syngas compressor & -16.8 & -18.1 & -5 & -17 & -17 & -17.5 & -16.6 \\
\hline Reformer air compressor & -1 & -1.4 & -1.1 & 0 & 0 & -1.1 & -1 \\
\hline $\mathrm{CO}_{2}$ compressor & -0.5 & -2.5 & -0.5 & 0 & 0 & -0.5 & -0.5 \\
\hline Clean syngas compressor & -6.9 & -6.6 & -6.9 & -6.1 & -5.9 & -7 & -6.8 \\
\hline Recycle compressor & -0.3 & -0.2 & -0.3 & -0.4 & -0.4 & -0.3 & -0.3 \\
\hline Boiler air compressors & -0.9 & -0.1 & -0.8 & -2.2 & -2.1 & -1 & -0.9 \\
\hline miscellaneous & -8 & -8 & -8 & -8 & -8 & -8 & -8 \\
\hline \multicolumn{8}{|l|}{ Power Production, MW } \\
\hline Steam turbines & 50.8 & 47.6 & 50.8 & 60.5 & 60.5 & 52.5 & 50.3 \\
\hline Net Power Output, MW & 11.5 & 4.5 & 11.2 & 22.1 & 22.3 & 12.4 & 11.4 \\
\hline
\end{tabular}


Table 3.2. Equipment and Capital Cost Results for Indirectly Heated Gasifier Based System Models

\begin{tabular}{|c|c|c|c|c|c|c|c|}
\hline Case & Base & A1 & $\mathbf{A 2}$ & A3 & A4 & A5 & A6 \\
\hline Case Description & Base & $\begin{array}{c}1.7 / 1.0 \\
\mathrm{H}_{2} / \mathrm{CO} \\
\text { Ratio }\end{array}$ & $\begin{array}{c}\text { Increased } \\
\text { Gasifier } \\
\text { Pressure }\end{array}$ & $\begin{array}{c}\text { No Steam } \\
\text { Reformer Const. } \\
\mathrm{H}_{2} \text {, CO partial } \\
\text { Pressures }\end{array}$ & $\begin{array}{c}\text { No Steam } \\
\text { Reformer } \\
\text { Constant Total } \\
\text { Pressure }\end{array}$ & $\begin{array}{c}\text { Double } \\
\text { Tar } \\
\text { Conc. }\end{array}$ & $\begin{array}{l}\text { One- } \\
\text { Half Tar } \\
\text { Conc. }\end{array}$ \\
\hline \multicolumn{8}{|l|}{ Installed Equipment Costs,:mm\$ } \\
\hline Feed prep and drying & 24.7 & 25.6 & 35.9 & 24.7 & 24.7 & 24.7 & 24.7 \\
\hline Gasifier and cyclones & 33.0 & 39.5 & 37.2 & 33.0 & 33.0 & 33.0 & 33.0 \\
\hline Tar cracker & 4.4 & 5.3 & 4.4 & 4.4 & 4.4 & 4.4 & 4.4 \\
\hline Gasifier heat recovery & 0.5 & 0.6 & 0.5 & 0.5 & 0.5 & 0.5 & 0.5 \\
\hline Syngas compression & 23.5 & 23.9 & 4.8 & 23.6 & 23.6 & 23.9 & 23.4 \\
\hline Sulfur removal & 3.6 & 3.6 & 3.6 & 3.6 & 3.6 & 3.6 & 3.6 \\
\hline Steam reformer (SR) & 12.0 & 14.6 & 12.5 & 0.0 & 0.0 & 11.7 & 12.0 \\
\hline WGS & 0.0 & 0.0 & 0.0 & 0.9 & 0.9 & 0.0 & 0.0 \\
\hline SR or WGS heat recovery & 3.4 & 3.9 & 3.5 & 0.9 & 0.9 & 3.5 & 3.3 \\
\hline SR or WGS $\mathrm{CO}_{2}$ compressor & 0.4 & 1.0 & 0.4 & 0.0 & 0.0 & 0.4 & 0.4 \\
\hline Amine $\mathrm{CO}_{2}$ removal & 20.2 & 28.3 & 21.3 & 19.1 & 19.1 & 20.1 & 20.0 \\
\hline Clean syngas compression & 8.6 & 8.3 & 8.7 & 8.2 & 8.1 & 8.7 & 8.5 \\
\hline Mixed alcohols synthesis & 43.3 & 34.4 & 42.2 & 49.4 & 46.7 & 44.1 & 42.7 \\
\hline Mixed alcohol recycle & 17.8 & 17.6 & 18.5 & 17.6 & 16.0 & 18.0 & 17.6 \\
\hline Mixed alcohol separations & 12.8 & 12.9 & 13.1 & 11.3 & 11.3 & 12.9 & 12.7 \\
\hline Steam system and power & & & & & & & \\
\hline $\begin{array}{l}\text { generation } \\
\text { Remainder OSBL }\end{array}$ & $\begin{array}{r}19.8 \\
3.7\end{array}$ & $\begin{array}{r}18.0 \\
3.8\end{array}$ & $\begin{array}{r}19.3 \\
3.6\end{array}$ & $\begin{array}{r}26.3 \\
3.7\end{array}$ & $\begin{array}{r}26.3 \\
3.7\end{array}$ & $\begin{array}{r}20.2 \\
3.7\end{array}$ & $\begin{array}{r}19.6 \\
3.7\end{array}$ \\
\hline Total Installed, $\mathrm{mm \$}$ & 232 & 241.4 & 229 & 227 & 223 & 233 & 230 \\
\hline Total Indirect, mm\$ & 118 & 123.1 & 117 & 116 & 114 & 119 & 117 \\
\hline Total Capital Inv, mm\$ & 350 & 364.5 & 346 & 343 & 336 & 353 & 348 \\
\hline
\end{tabular}

Table 3.3. Operating Cost Results for Indirectly Heated Gasifier Based System Models

\begin{tabular}{|c|c|c|c|c|c|c|c|}
\hline Case & Base & A1 & A2 & A3 & A4 & A5 & A6 \\
\hline Case Description & Base & $\begin{array}{c}1.7 / 1.0 \\
\mathrm{H}_{2} / \mathrm{CO} \\
\text { Ratio } \\
\end{array}$ & $\begin{array}{c}\text { Increased } \\
\text { Gasifier } \\
\text { Pressure }\end{array}$ & $\begin{array}{l}\text { No Steam } \\
\text { Reformer } \\
\text { Const. } \mathrm{H}_{2} \text {, } \\
\mathrm{CO} \text { partial } \\
\text { Pressures }\end{array}$ & $\begin{array}{c}\text { No Steam } \\
\text { Reformer } \\
\text { Constant } \\
\text { Total } \\
\text { Pressure }\end{array}$ & $\begin{array}{l}\text { Double } \\
\text { Tar } \\
\text { Conc. }\end{array}$ & $\begin{array}{l}\text { One- } \\
\text { Half Tar } \\
\text { Conc. }\end{array}$ \\
\hline \multicolumn{8}{|l|}{ Variable Costs, $\$ \mathrm{~mm} / \mathrm{y}$} \\
\hline Hybrid Poplar Chips & 25.330 & 25.330 & 25.330 & 25.330 & 25.330 & 25.330 & 25.330 \\
\hline Olivine makeup & 0.307 & 0.307 & 0.307 & 0.307 & 0.307 & 0.307 & 0.307 \\
\hline Ash disposal & 0.405 & 0.405 & 0.405 & 0.405 & 0.405 & 0.405 & 0.405 \\
\hline Misc Chemicals & 1.881 & 1.885 & 1.925 & 1.587 & 1.588 & 1.915 & 1.867 \\
\hline Tar Reformer Catalyst & 0.376 & 0.377 & 0.385 & 0.317 & 0.318 & 0.383 & 0.373 \\
\hline Mixed Alcohols Catalyst & 0.223 & 0.157 & 0.210 & 0.235 & 0.235 & 0.226 & 0.210 \\
\hline Wastewater treatment & 1.463 & 1.692 & 1.296 & 1.495 & 1.493 & 1.447 & 1.460 \\
\hline Cooling water & 3.195 & 3.489 & 2.493 & 3.298 & 3.293 & 3.190 & 3.177 \\
\hline Natural gas & 0.000 & 0.000 & 0.000 & 0.000 & 0.000 & 0.000 & 0.000 \\
\hline Electricity & -6.101 & -2.413 & -5.967 & -11.779 & -11.875 & -6.595 & -6.091 \\
\hline Propanol + Credit $^{\mathrm{a}}$ & -52.282 & -52.212 & -53.425 & -44.238 & -44.247 & -53.242 & -51.888 \\
\hline Total Variable, $\$ \mathrm{~mm} / \mathrm{yr}$ & -25.202 & -20.981 & -27.042 & -23.042 & -23.154 & -26.634 & -24.849 \\
\hline Fixed Costs, $\$ \mathrm{~mm} / \mathrm{yr}$ & 16.802 & 17.289 & 16.677 & 16.581 & 16.359 & 16.893 & 16.729 \\
\hline Depreciation (5\%/yr), \$mm/yr & 17.491 & 18.226 & 17.294 & 17.157 & 16.822 & 17.629 & 17.381 \\
\hline Gen \& Admin, \$mm/yr & 5.071 & 5.431 & 4.997 & 4.697 & 4.627 & 5.073 & 5.048 \\
\hline ROI (10\%/yr), \$mm/yr & 34.982 & 36.452 & 34.589 & 34.314 & 33.644 & 35.258 & 34.762 \\
\hline EtOH Production, mmgal/yr & 37.626 & 37.708 & 38.498 & 31.744 & 31.767 & 38.305 & 37.336 \\
\hline Total Variable, \$/gal EtOH & -0.670 & -0.556 & -0.702 & -0.726 & -0.729 & -0.695 & -0.666 \\
\hline Fixed Costs, \$/gal EtOH & 0.447 & 0.458 & 0.433 & 0.522 & 0.515 & 0.441 & 0.448 \\
\hline Depreciation, \$/gal EtOH & 0.465 & 0.483 & 0.449 & 0.540 & 0.530 & 0.460 & 0.466 \\
\hline Gen \& Admin, \$/gal EtOH & 0.135 & 0.144 & 0.130 & 0.148 & 0.146 & 0.132 & 0.135 \\
\hline ROI, \$/gal & 0.930 & 0.967 & 0.898 & 1.081 & 1.059 & 0.920 & 0.931 \\
\hline Estimated Selling Price, $\$ /$ gal & 1.306 & 1.496 & 1.208 & 1.566 & 1.520 & 1.259 & 1.314 \\
\hline
\end{tabular}


The alcohol-product-distribution, CO-conversion, and product-selectivity assumptions for the alcohol synthesis reactor are similar to those used by Aden et al. (2005). Additional details on the base process flow sheet and modeling results are provided in Appendix B.

\subsubsection{Case A1: Raw Gas Composition with $\mathrm{H}_{2}$ : $\mathrm{CO}$ Ratio Close to 1.7:1}

Case Al examines the effect of producing a raw gas from the gasifier with a significantly higher $\mathrm{H}_{2}$ :CO ratio of approximately $1.7: 1$. The motivation for this case is that the product gas correlations (Section 2.1.2) are based on a gasifier that was meant to make medium BTU fuel gas to use in place of natural gas in boiler and gas turbine applications. Consequently, the research did not investigate operating parameters that might have improved the $\mathrm{H}_{2}$ :CO ratio to a value more suitable for syngas applications. It also placed a premium on the amount of methane in the raw product gas because it increased the energy density of the product gas. To investigate a case in which the $\mathrm{H}_{2}$ : $\mathrm{CO}$ ratio is higher, the raw gas composition is adjusted to be similar to the measured dry composition reported by Hofbauer et al. (2002) adjusted to a wet gas composition using the reported steam addition rate reported by Hofbauer and Rauch (2001) for their indirectly heated gasifier, which used quartz sand as the fluidizing medium. This gasifier produces a medium BTU gas with a 1.7:1 $\mathrm{H}_{2}: \mathrm{CO}$ ratio. Using Hofbauer's gas composition also requires adopting the reported operating temperature and pressure of $900^{\circ} \mathrm{C}$ and $1 \mathrm{~atm}$. As shown in Table 3.1, the methane content of the raw gas is about half that of the Base Case, while the water and $\mathrm{CO}_{2}$ concentrations are higher. The production of tar is calculated from the correlation developed by Spath et al. (2005). The char production and steam injection are adjusted to balance the C, $\mathrm{H}$, and $\mathrm{O}$ components of the outlet gas with the inlet feed.

Performance Results. As shown in Table 3.1, the $\mathrm{H}_{2}$ : $\mathrm{CO}$ ratio in the raw syngas in Case Al is not only higher than that of the Base Case, but it also is higher than the specified $\mathrm{H}_{2}$ : $\mathrm{CO}$ ratio for mixed alcohol synthesis $\left(\mathrm{H}_{2}: \mathrm{CO}=1.2\right)$. The cooled, scrubbed, raw syngas flow rate of Case $A 1$ is approximately $28 \%$ higher than that of Base Case and, thus, increases the raw gas compressor power consumption by about 1.2 MW. The higher $\mathrm{CO}_{2}$ content in raw syngas of Case Al also increases the size of amine scrubber system. Because the $\mathrm{CO}_{2}$ is removed from the raw gas in the amine scrubber, before most of the methane is reformed, the $\mathrm{H}_{2}$ : $\mathrm{CO}$ ratio must be reduced by re-injecting a large quantity of $\mathrm{CO}_{2}$ under pressure into the steam reformer, which increases the $\mathrm{CO}_{2}$ compressor power consumption.

The lower methane content in the raw gas results in a correspondingly lower concentration of methane in the syngas leaving the reformer. This, in turn, produces a lower total gas flow rate entering the alcohol synthesis reactor.

To match the higher water content of the raw gas leaving the reactor in Case A1, additional steam must be injected into the gasifier and passed through the cyclones. Therefore, the steam available for power generation decreases; thus, the total net power output also decreases. In addition, the higher water content in the raw syngas increases the wastewater treatment and cooling water loads in the gas cleanup section.

In Case A1, the char production, which is estimated by balancing the mass between the inlet and outlet streams, is higher than that of Base Case, which leads to higher air consumption in the combustor and, thus, higher air compressor power consumption. 
The change in raw syngas composition has no obvious effects on the product yield and carbon efficiency in the alcohol synthesis and recovery section, which are almost the same for the two cases.

Economic Effects. Table 3.2 summarizes the capital costs associated with the Base Case and Case A1. Increasing steam to the gasifier increases the total gasifier flow rate, resulting in a $20 \%$ increase in gasification area equipment costs, which is mainly due to the primary gasifier cyclone cost. The gasifier cost, which is based on the wood feed rate, is not affected by changes in the raw gas volume flow rate. A similar increase is noted in the tar cracker. The cost estimates for cyclones and tar crackers are based on the inlet stream volume flow rate. Because of the high $\mathrm{H}_{2}$ content in raw syngas, the volumetric flow rate is $58.6 \mathrm{Nm}^{3}$ compared to $45.8 \mathrm{Nm}^{3}$ in the Base Case. The raw syngas volume flow rate increases about $28 \%$. Equipment costs in the steam reformer section increases because of increased flow to the reformer from the additional $\mathrm{CO}_{2}$ and higher overall reforming duty. However, the lower methane level in the syngas leaving the steam reformer reduces the equipment costs in the alcohol synthesis section by about $17 \%$. The steam turbine system equipment costs are reduced by $10 \%$ because of the lower steam rate. Net power produced by the integrated process is reduced as a result of the increased air, raw syngas, and $\mathrm{CO}_{2}$ compressor power requirements and decreased steam flow available for power generation.

This case increases the selling price cost over the Base Case by $\$ 0.20 /$ gal. Approximately half of this increase is the result of lower net power generation in the steam turbines and, thus, a lower electricity credit. About another quarter of the increase can be attributed to increased capital related costs.

Model Limitations. The main cost limitation of the model is that the gasifier vessel cost is based on the dry biomass feed rate and does not capture the effect of gasifier vessel size changes needed to accommodate process changes such as increased steam injection. However, this type of effect is captured in the cyclone separators as their costs scale with the gas flow rate. The tar concentration may be lower than that calculated by the correlation (Section 2.1.1) at Case Al conditions. Finally, the results are somewhat confounded in that the syngas is not at the appropriate $\mathrm{H}_{2} / \mathrm{CO}$ ratio for the synthesis step in either Case Al or the Base Case, and there is no suitable correlation to determine the gas composition at an intermediate set of gasifier conditions.

Analysis. Regardless of the gasifier equipment sizing and costing limitations, it is clear that changing the reactor conditions to alter the $\mathrm{H}_{2}$ : $\mathrm{CO}$ ratio has a significant impact on the cost of producing ethanol, and therefore, its selling price. In Case A1, changing the $\mathrm{H}_{2}$ : $\mathrm{CO}$ ratio from 0.57 to 1.7 increased the ethanol price by about $15 \%$. However, much of cost increase is due to the requirement for higher $\mathrm{CO}_{2}$ injection to the reformer as well as increased gas flows (specifically steam and $\mathrm{CO}_{2}$ flows) to the gasifier, cyclone separators, scrubber, and cooled raw gas compressors. It may be that an intermediate set of operating conditions between the Base Case and Case A1 that produce a raw gas that more closely matches the synthesis $\mathrm{H}_{2}$ : $\mathrm{CO}$ ratio of 1.2 , might require less steam to the gasifier, resulting in lower overall processing costs. Alternatively, if the conversion, selectivity, and productivity of the alcohol synthesis reactor are found to be insensitive to the $\mathrm{H}_{2}: \mathrm{CO}$ ratio, the costs required to adjust the $\mathrm{H}_{2}: \mathrm{CO}$ ratio in the raw gas can be avoided.

\subsubsection{Case A2. Gasifier Pressure Increases to 10 Atm}

Case $A 2$ investigated the effects of increasing the gasifier pressure. This case is motivated by the absence of data for an indirectly heated gasifier operating at elevated pressure, and the apparent 
preference to operate directly heated gasifiers at elevated pressure. For Case A2, the gasifier pressure is increased to $147 \mathrm{psi}(10 \mathrm{~atm})$. The gasifier correlation in Section 2.1.1 is used in this case. Because the gasifier operates at high pressure, a lock-hopper feeder system is used to feed the dried wood into the gasifier. Pressurized $\mathrm{CO}_{2}$ recovered from the gas purification and conditioning section of the plant is used in the lock hopper as the feedstock carrier. The $\mathrm{CO}_{2}$ is fed at a flow rate of $0.03 \mathrm{lb}$ of $\mathrm{CO}_{2} / \mathrm{lb}$ of dried wood and compressed to $150 \mathrm{psi}$. The gasifier combustion zone also operates at high pressure. The air is compressed to 150 psi using a multistage intercooling compressor, and then sent to the combustion zone. Compared to the Base Case, the raw syngas is at higher pressure; thus, the downstream processes are modified to match the pressure change.

Performance Results. Compared to the Base Case, the raw syngas composition modeled in Case A2 has a higher $\mathrm{CO}_{2}$ content because extra $\mathrm{CO}_{2}$ from the gas purification process is used as the lock-hopper feed gas and is sent with the dried wood to the gasifier. The compositions for the other components and the $\mathrm{H}_{2}: \mathrm{CO}$ ratio are very close to the Base Case. Using $\mathrm{CO}_{2}$ as feed gas also leads to a higher scrubbed dry raw gas flow rate.

Case $A 2$ has the same $\mathrm{CO}_{2}$ feed rate to the steam reformer as the Base Case. The steam injection is increased to reach the required $\mathrm{H}_{2}$ : $\mathrm{CO}$ ratio. The higher $\mathrm{CO}_{2}$ content in the raw syngas and the higher steam:feed ratio results in greater methane conversion and a higher overall flow rate of clean syngas. Compared to the Base Case, Case A2 has a higher final product yield and higher carbon efficiency. These improvements are attributed to a greater fraction of the methane in the raw gas being converted to $\mathrm{CO}$ and $\mathrm{H}_{2}$ in the steam reformer.

The power consumption results show that increasing the gasification pressure leads to a very small change in net power output compared to the Base Case. In Case A2, power consumption for the char combustor air compressor is much higher than that of Base Case as is the power needed for compressing the lock-hopper $\mathrm{CO}_{2}$. However, these power increases are balanced by the lower compression power needed to boost the raw syngas pressure.

Economic Effects. Because of the increased gasifier pressure, the installed cost for the feed preparation and drying section increases by $\$ 11.2$ million. The installed cost for the gasifier and cyclone separators increases by $\$ 4.2$ million, whereas the power needed for raw syngas compression decreases by $\$ 18.7$ million. The total project investment for Case $A 2$ is lower than that for the Base Case by $\$ 4$ million, mainly because of the lower cost for sygnas compression. Overall, the ethanol selling price decreases by about 7\% from the Base Case because of the reduced capital charges and increased ethanol yield.

Model Limitations. The syngas composition correlations (Section 2.1.1) may not accurately reflect high-pressure operation. The correlations were based on experimental data for near atmospheric conditions and do not have a correction for high-pressure operation. However, the cost estimate for the gasifier vessel does reflect the effect of operating at higher pressure.

Analysis. Although pressure increases the gasifier section cost, the higher raw gas pressure reduces the cost for syngas gas compression. Overall, the estimated ethanol selling price is lower than that of Base Case and appears to have a positive effect. Gasification above $10 \mathrm{~atm}$ with this type of gasifier requires further research. 


\subsubsection{Case A3. Methane/Ethane are not Reformed and Clean Syngas Pressure Changed to Maintain $\mathrm{H}_{2} / \mathrm{CO}$ Partial Pressures}

Case $A 3$ investigates the effects of not reducing the methane and ethane content in the syngas. This case focused on determining the effect of eliminating the capital and operating costs associated with a steam reformer against the expected loss of mixed-alcohol yield. The total pressure of clean syngas to the synthesis reactor is varied to maintain the same $\mathrm{H}_{2}$ and $\mathrm{CO}$ partial pressures. The steam reformer in the Base Case is replaced by a WGS reactor, which is used to adjust the $\mathrm{H}_{2}$ :CO ratio to match the synthesis requirement of 1.2:1. Methane and ethane are considered to be inert in the WGS reaction. Mediumpressure steam in a steam:CO ratio of 3:1 is used in the WGS process. After shift, the syngas is compressed to $2096 \mathrm{psi}$ (2091 psi alcohol synthesis reactor pressure) to match the partial pressure of CO and $\mathrm{H}_{2}$ in the Base Case.

Performance Results. Case A3 has the same raw syngas composition as the Base Case. The clean syngas molar flow rate is less than that of Base Case because none of the methane and ethane in the scrubbed gas is steam reformed to $\mathrm{CO}$ and $\mathrm{H}_{2}$, resulting in a net decrease of the total moles of dry gas (see Equation 2.4). This, in turn, reduces the yield of mixed alcohol products to less than $16 \%$ of the Base Case.

While the syngas pressure must be increased to achieve the same $\mathrm{H}_{2}$ and $\mathrm{CO}$ partial pressures in the clean syngas, the lower flow rate of clean syngas compensates so that the compressor power consumption is about $12 \%$ less than that of the Base Case. Because the methane and ethane do not react in the alcoholsynthesis reactor, they build up to higher concentrations in the recycle streams in alcohol synthesis process, increasing the total flow to the synthesis reactor. While the recycle compressor duty does increase significantly, it is such a small value relative to the rest of the power needs that it does not impact the net power consumption. Elimination of the $\mathrm{CO}_{2}$ and air compressors for the steam reformer reduces the overall compression power demand. Also, more gas must be purged from the alcohol synthesis recycle loop to maintain an acceptably low concentration of hydrocarbon impurities in the alcoholsynthesis reactor. The purged gas is sent to the steam cycle for power generation. This increases the steam capacity requirements of the purge gas-fired superheater and the gas-fired boiler, resulting in an increase in the air compressor power requirements for the boiler and superheater. However, $10 \mathrm{MW}$ more power is generated, which is nearly double the power generated in the Base Case.

Economic Effects. The elimination of the steam reformer also eliminates the $\mathrm{CO}_{2}$ and air compressor costs and replaces the cost of the steam reformer with a less expensive WGS reactor. The clean syngas compressor cost is also lower than that of the Base Case because of the lower syngas flow. The installed equipment cost for mixed-alcohol synthesis is $14 \%$ higher than the Base Case because of a greater recycle syngas flow to the synthesis reactor and the higher synthesis pressure of 2096 psi. Because more steam and electricity are generated in this case, the equipment costs for this case also increase. As a result the total project investment for Case $A 3$ is almost $\$ 7 \mathrm{~mm}$ less than for the Base Case.

The yield loss causes reduced byproduct credits that are partially offset by a higher electricity credit. The net variable cost of Case A3 is about 9\% higher than that for the Base Case. Overall, the ethanol per gallon cost is $\$ 0.55 / \mathrm{gal}$ higher for Case A3. This is attributed to the $16 \%$ lower production rate of ethanol, which in turn is attributed to the lower yield of $\mathrm{H}_{2}$ and $\mathrm{CO}$ in the clean syngas because the methane was not steam reformed. 
Model limitations. No significant limitations were noted for this case.

Analysis: Although eliminating the steam reformer and associated compressors reduces the capital cost and power generation revenue is increased, the reduced yield of mixed alcohols results in a higher ethanol cost on a per gallon basis. Thus, the reduction in mixed alcohol yields more than offsets the economic benefits of eliminating the steam reformer, thus resulting in a higher unit cost of ethanol.

\subsubsection{Case A4. Methane/Ethane is Assumed to be Inert and Clean Syngas Pressure Unchanged}

Case $A 4$ also investigated the effect of the not steam reforming the syngas to remove methane and ethane. Unlike Case A3, this case does not adjust the synthesis reactor partial pressure of $\mathrm{H}_{2}$ and $\mathrm{CO}$ to match that of the Base Case. This case was conducted to differentiate between the effects of the alcoholsynthesis reactor pressure increase of Case $3 A$ and the cost savings of eliminating the steam reformer.

Performance Results. The only difference between Case $A 4$ and Case $A 3$ is the alcohol-synthesis pressure. The clean syngas in Case $A 4$ is compressed to 2000 psia, which is the same as in the Base Case, whereas the clean syngas in Case A3 is compressed to 2096 psi. The partial pressure of CO and $\mathrm{H}_{2}$ in Case $4 A$ is lower than that of the Base Case because of the large amount of methane and ethane in the syngas.

Power consumption for the clean syngas compressor and the boiler and superheater air compressor for Case A4 is slightly lower than that in Case A3 because of the slightly lower synthesis pressure in Case A4. This results in a small increase in the net power production for Case A4.

Economic Effects. Compared to Case A3, the differences in the variable costs are very small, and are caused by the modest decreases in power consumption for the syngas compressor, boiler, and superheater air compressors. The installed equipment cost for the alcohol synthesis equipment in this case is lower than that of Case $A 3$ because of the lower reactor pressure requirement. However, the equipment cost savings and the reduced variable costs are still insufficient to overcome the effects of reduced higher alcohol yields. As a result, the selling price for ethanol is well above that for the Base Case.

Model Limitations. Case $A 4$ has lower $\mathrm{CO}$ and $\mathrm{H}_{2}$ partial pressures in the alcohol-synthesis reactor than in the Base Case. The lower partial pressure would normally be expected to lower the $\mathrm{CO}$ conversion per pass resulting in lower higher alcohol yields and higher gas-recycle rates. The $\mathrm{CO}$ conversion per pass in the current model is constant and does not reflect the impact of changed $\mathrm{CO}$ and hydrogen partial pressures. Both effects would make the selling price higher than estimated for this case.

Analysis. Similar to Case $A 3$, not converting the methane and ethane to $\mathrm{H}_{2}$ and $\mathrm{CO}$ decreases the system carbon efficiency and, thus, leads to a higher production cost. In Case A4, the synthesis pressure is assumed to be unchanged, while in Case A3, the synthesis pressure is increased to match the Base Case $\mathrm{H}_{2}$ and $\mathrm{CO}$ partial pressures. Comparing these two cases, although the two cases have the same carbon efficiencies and final product yields, the cost for Case A4 is lower because of the lower synthesis pressure. Therefore, the lower process pressure would lower the system cost. 


\subsubsection{Case A5: Tar Production is Assumed to be Double that of Base Case}

Case $A 5$ examines the effects of doubling the tar content in raw syngas on the final product yield and cost. This case is motivated by uncertainty in the reported tar concentrations in the raw gas from various gasifiers because of differences in the methods used to quantify them. It is not intended to suggest increasing or decreasing the tar content intentionally.

In this case, the char production rate is assumed to remain the same. To increase tar production, the total mass flow rate of the gas components in the raw gasifier product gas are decreased, and the carbon content of the char is adjusted to maintain the overall mass balance. The molar fraction for each gas component, as estimated by correlations developed by Spath et al. (2005), remained the same with respect to each other because the temperature used in the correlations is the same as the Base Case. However, the absolute rate for each gas component is decreased to account for the increased concentration of tar in the raw gas.

Performance Results. As shown in Table 3.1, the concentration of tar in the syngas is double that of the Base Case. Because tar production increases, the hydrogen and carbon components in the tar increase. These components are provided to the tar by uniformly reducing the concentrations of the noncondensable gases, such as $\mathrm{H}_{2}, \mathrm{CO}, \mathrm{CO}_{2}$, and $\mathrm{CH}_{4}$, in the raw gas, and exchanging a portion of the carbon in the char for oxygen. This maintains a constant char mass flow rate and overall carbon, hydrogen, and nitrogen atom balances. Thus, the total mass flow rate of char stays the same as the Base Case, while the carbon component in the char decreases. The net result is that the total carbon in the raw gas associated with the gases and the tar has increased in Case A5 compared to the Base Case.

The majority of the tar is converted into $\mathrm{H}_{2}$ and $\mathrm{CO}$ in the tar cracking unit. As a result, the scrubbed syngas on a dry basis for Case $A 5$ has more $\mathrm{H}_{2}$ and $\mathrm{CO}$ than that of the Base Case. The scrubbed syngas is further sent to the steam reformer to convert part of the methane and remaining tar into $\mathrm{CO}$ and $\mathrm{H}_{2}$. The clean syngas flow rate of Case A5 is higher than that of the Base Case because more $\mathrm{H}_{2}$ and $\mathrm{CO}$ is produced from the higher tar content. The increased $\mathrm{H}_{2}$ and $\mathrm{CO}$ in the syngas leads to a $2 \%$ increase in the ethanol yield.

The power consumption of raw syngas compressor of Case A5 is greater than that of the Base Case due to higher syngas flow. Higher syngas flow in the clean syngas also leads to more off-gas sent to the steam cycle for power generation. The steam turbine power generation of Case A5 is higher than the Base Case, and the net power output of Case A5 is slightly higher than the Base Case.

Economic Effects. Table 3.2 summarizes the equipment costs for Case A5. Increasing tar production increases the cost of the gasifier and syngas cleaning and conditioning sections of the plant by less than $2 \%$. Case A5 has only a slightly higher equipment cost as the Base Case.

Because of higher yields of ethanol and the higher alcohol byproducts, plus increased power output, the variable costs for Case A5 are lower than that of Base Case. The ethanol price decreased approximately $\$ 0.05 /$ gal as compared to the Base Case, mainly because of the increased mixed alcohol yield.

Model Limitations. A key limitation in this case is the manner in which tar concentration is achieved. Here, the gaseous components are a source of a portion of the tar, with the char being a second source. Consequently, the composition of the char changes so that it contains more oxygen. This is not necessarily the correct model for this phenomenon; although under the high-temperature gasifier 
conditions, the tar that is cracked likely produces both char and gas (although cracking decreases tar, which is the opposite of this case). Whether or not the char loses oxygen in the process is subject to debate. However, considering the modest effect of doubling the tar concentration on the ethanol selling price, it is unlikely that a more accurate method for increasing the tar concentration would result in a significantly different result. Another limitation is that the gasifier vessel cost is based on the dry biomass feed rate and does not reflect the effects of tar production increase on the vessel size or other design specifications. In addition, the tar reforming cost is calculated from the inlet sygnas volume flow rate, which does not capture the equipment size increase needed to compensate for the increased residence time that may be required to reform the extra tar. These limitations, which are not expected to have major effects on the selling price, would offset some of the selling price decrease.

Analysis. Overall, the decrease in the ethanol selling price due to a doubling of the tar content in the raw gas is fairly modest. The primary reason for this is the increased ethanol yield because the carbon content is higher in the syngas and lower in the char. Two conclusions can be derived from this case. First, the fact that there is more tar in the gas is not detrimental and, in fact, may be modestly beneficial to the overall process economics as long as the tar can be efficiently reformed to gas. Second, increasing the inventory of $\mathrm{H}_{2}$ and $\mathrm{CO}$ in the clean syngas, whether by decreasing the amount of carbon in the char or by greater reforming efficiencies for the tar (or other hydrocarbons such as methane), has a very significant impact on the ethanol selling price, because of the increase mixed-alcohol yields.

\subsubsection{Case A6: Tar Production is Assumed to be Half that of the Base Case}

Case $A 6$ is a companion to Case $A 5$ in that it examines the effect of decreasing the tar content in raw syngas by a factor of two. Using the same methodology used in Case A5, the char production rate remains the same, while the total mass flow rate of the gas components in the raw gasifier product gas is increased, and the carbon content of the char is adjusted to maintain the overall mass balance. The molar fraction for each gas component, estimated by the correlations developed by Spath et al. (2005), remain the same with respect to each other because the temperature used in the correlations is unchanged in this case, when compared to the Base Case. However, the absolute concentrations increase to account for the decreased concentration of tar in the raw gas.

Performance Results. As might be expected, the effects of halving the tar production rate on the overall process were similar to those in Case $5 \mathrm{~A}$, but in the opposite direction and with approximately half the impact because the quantity of the tar decrease in this case is one-half the quantity of tar increase in Case $5 \mathrm{~A}$. With less dry clean syngas produced, the yield of mixed alcohols is similarly reduced. The power consumptions of the raw gas and clean gas compressors for Case A6 are lower than that of Base Case. Because less syngas is used for synthesis, less off-gas is sent to the steam cycle for power generation. The steam turbine power generation for Case A6 is lower than that of the Base Case; therefore, the net power output of Case A6 is almost the same as the Base Case.

Economic Effects. Case A6 requires a slightly lower capital investment than that of the Base Case. The costs for the gasifier and tar reformers are almost the same as for the Base Case. Because of the model limitation, the cost of the tar reformer may be overestimated because less tar is produced in Case A6.

Because the final product yield is slightly lower, the total variable credit for this case is lower than that of the Base Case. The production cost is close to that of the Base Case; therefore, the effect of lowering the tar production on cost is minor at best. 
Model Limitations: The limitations for this model are similar to those for Case A5.

Analysis. Lowering the tar production to half that of the Base Case results in a very slight increase in cost. The main reason is that original tar production is already very small, thus lowering it by half causes about half the magnitude of the changes that occurred when the tar concentration was doubled in Case 5 A.

\subsection{Directly Heated Gasifier Scenarios}

Seven cases are considered for the mixed-alcohol synthesis plant based on the directly heated gasifier:

Base Case: The raw gas composition is from correlations developed by Eggeman (2005) based on experimental data reported in Evans et al. (1988) using the Gas Technology Institute's 12 ton/day process research unit.

Case B1: The gasification pressure is decreased to $20 \mathrm{psig}$, compared to $330 \mathrm{psig}$ for the Base Case. The syngas is assumed to have the same composition as that predicted at higher pressure.

Case B2: The gasification pressure is changed to 20 psig. The syngas composition is adjusted by extrapolating the gasifier correlations to 20 psig.

Case B3: The steam reformer is replaced by a simple shift reactor. Methane and ethane are assumed to be inert in the synthesis step. The total syngas pressure is increased to maintain the same $\mathrm{H}_{2}$ and $\mathrm{CO}$ partial pressures as in the Base Case.

Case B4: The same assumptions as used in Case $A 3$ apply, except that the total syngas pressure is unchanged from the Base Case.

Case B5: The tar production rate is double that of the Base Case.

Case B6: The tar production rate is one-half of that in the Base Case.

Table 3.4 summarizes the operating conditions and performance results for the directly fired pressurized gasifier cases. Tables 3.5 and 3.6 summarize the associated capital and operating costs, respectively. These cases are similar to the cases examined for the indirectly heated gasifier scenarios. They are considered mainly to identify any instances where the type of gasifier has an influence on the overall economics.

\subsubsection{Base Case}

The Base Case uses the process configurations shown in Figures 2.2, 2.3, 2.4, 2.5, and 2.7. The correlation model developed from the data of Evans (1988) is used to estimate the raw syngas compositions. Selected key operating parameters for these unit operations are:

- Gasifier Pressure - 330 psia

- Gasifier Temperature $-871^{\circ} \mathrm{C}\left(1600^{\circ} \mathrm{F}\right)$

- Alcohol synthesis Reactor Temperature $-299^{\circ} \mathrm{C}\left(570^{\circ} \mathrm{F}\right)$

- Alcohol Synthesis Reactor Pressure - 1995 psia

- Alcohol Synthesis Reactor feed $\mathrm{Gas}_{2}$ :CO ratio - 1.2.

The alcohol product-distribution, CO-conversion, and product-selectivity assumptions for the alcohol synthesis reactor are similar to those used by Aden et al. (2005). Additional details on the base process flow sheet and modeling results are provided in Appendix C. 
Table 3.4. Performance Results for Directly Heated Gasifier Based System Models

\begin{tabular}{|c|c|c|c|c|c|c|c|}
\hline Case & Base & B1 & $\mathrm{B} 2$ & B3 & B4 & $\mathrm{B} 5$ & B6 \\
\hline Case Description & Base & $\begin{array}{l}\text { Decreased } \\
\text { Gasifier } \\
\text { Pressure } \\
\text { (Syngas } \\
\text { Unchanged) }\end{array}$ & $\begin{array}{c}\text { Decreased } \\
\text { Gasifier } \\
\text { Pressure } \\
\text { (Syngas } \\
\text { Changed) }\end{array}$ & $\begin{array}{l}\text { No Steam } \\
\text { Reformer } \\
\text { Const. } \mathrm{H}_{2} \text {, } \\
\mathrm{CO} \text { partial } \\
\text { Pressures }\end{array}$ & $\begin{array}{c}\text { No Steam } \\
\text { Reformer } \\
\text { Constant } \\
\text { Total } \\
\text { Pressure }\end{array}$ & $\begin{array}{l}\text { Double Tar } \\
\text { Conc. }\end{array}$ & $\begin{array}{l}\text { One-Half } \\
\text { Tar Conc. }\end{array}$ \\
\hline Gasifier Pressure, psi & 330 & 20 & 20 & 330 & 330 & 330 & 330 \\
\hline $\begin{array}{l}\text { Gasifier Temperature, }{ }^{\circ} \mathrm{F} \\
\text { Raw Gas Compositions, Mol\% }\end{array}$ & 1600 & 1600 & 1600 & 1600 & 1600 & 1600 & 1600 \\
\hline Hydrogen & 15.4 & 15.6 & 9.9 & 15.4 & 15.4 & 15.3 & 15.5 \\
\hline Carbon monoxide & 15.1 & 15.3 & 21.9 & 15.1 & 15.1 & 14.6 & 15.2 \\
\hline Carbon dioxide & 26.3 & 25.4 & 17.2 & 26.3 & 26.3 & 25.8 & 26.4 \\
\hline Methane & 11.3 & 11.5 & 8.5 & 11.3 & 11.3 & 11.1 & 11.4 \\
\hline Water & 29.7 & 30.1 & 38.5 & 29.7 & 29.7 & 30.6 & 29.9 \\
\hline Benzene & 0.93 & 0.94 & 1.3 & 0.93 & 0.93 & 1.3 & 0.47 \\
\hline Naphthalene & 0.26 & 0.27 & 0.31 & 0.26 & 0.26 & 0.38 & 0.13 \\
\hline $\mathrm{C}_{2}+$ & 0.9 & 0.9 & 2.4 & 0.9 & 0.9 & 0.8 & 0.9 \\
\hline $\mathrm{H}_{2}: \mathrm{CO}$ ratio & 1.02 & 1.02 & 0.45 & 1.02 & 1.02 & 1.04 & 1.02 \\
\hline Char Production, $\mathrm{lbm} / \mathrm{hr}$ & 7510 & 7510 & 4196 & 7510 & 7510 & 1340 & 13743 \\
\hline $\begin{array}{l}\text { Scrubbed (dry) raw gas } \\
\text { flow rate, } \mathrm{lbmol} / \mathrm{hr}\end{array}$ & 11336 & 11220 & 11200 & 11840 & 11840 & 12285 & 10394 \\
\hline $\begin{array}{l}\text { Alcohol synthesis Pressure, psi } \\
\text { Alcohol Synthesis }\end{array}$ & 1995 & 1995 & 1995 & 2159 & 1995 & 1995 & 1995 \\
\hline $\begin{array}{l}\text { Temperature, }{ }^{\circ} \mathrm{F} \\
\text { Clean Syngas Composition, } \\
\text { Mol\% }\end{array}$ & 570 & 570 & 570 & 570 & 570 & 570 & 570 \\
\hline Nitrogen & 0.3 & 0.4 & 0.3 & 0.3 & 0.3 & 0.3 & 0.3 \\
\hline Hydrogen & 50.7 & 51.3 & 50.3 & 47.4 & 47.4 & 50.4 & 51.2 \\
\hline Carbon monoxide & 43.2 & 42.5 & 42.9 & 39.3 & 39.3 & 43 & 43.3 \\
\hline Carbon dioxide & 0.2 & 0.2 & 0.2 & 0.5 & 0.5 & 0.2 & 0.2 \\
\hline Methane & 5.5 & 5.6 & 6.3 & 12.1 & 12.1 & 6.1 & 4.9 \\
\hline Water & 0 & 0 & 0 & 0 & 0 & 0 & 0 \\
\hline $\mathrm{C}_{2}+$ & 0 & 0 & 0 & 0.3 & 0.3 & 0 & 0 \\
\hline $\mathrm{H}_{2}: \mathrm{CO}$ ratio & 1.17 & 1.21 & 1.17 & 1.21 & 1.21 & 1.17 & 1.18 \\
\hline $\begin{array}{l}\text { Clean Syngas Flowrate, } \\
\text { lbmol/hr } \\
\text { Final Products }\end{array}$ & 10351 & 10264 & 10687 & 8807 & 8807 & 11176 & 9502 \\
\hline Ethanol & 45.4 & 43.7 & 46.5 & 34.5 & 34.5 & 47.4 & 42.4 \\
\hline Propanol & 9.2 & 8.8 & 9.4 & 7.0 & 7.0 & 9.6 & 8.6 \\
\hline Butanol & 3.9 & 3.8 & 4 & 3.0 & 3.0 & 4.1 & 3.7 \\
\hline Pentanol & 1.9 & 1.9 & 2 & 1.5 & 1.5 & 2 & 1.8 \\
\hline Total & 60.4 & 58.1 & 61.9 & 45.9 & 46.0 & 63.2 & 56.5 \\
\hline Carbon Efficiency, \% & 30.1 & 29 & 30.9 & 22.9 & 22.9 & 31.2 & 28.1 \\
\hline Power Consumption, MW & & & & & & & \\
\hline Air separation unit & -8.6 & -7.7 & -7.7 & -8.6 & -8.6 & -8.6 & -8.6 \\
\hline Dryer Air Fan & -0.2 & -0.2 & -0.4 & -0.2 & -0.1 & -0.2 & 0 \\
\hline Lock hopper gas & & & & & & & \\
\hline compressor & -0.2 & 0 & 0 & -0.2 & -0.2 & -0.2 & -0.2 \\
\hline Air compressor & -0.5 & -0.9 & -0.5 & -0.5 & -0.5 & -0.2 & -1.7 \\
\hline Raw syngas compressor & -1.9 & -22.4 & -23.6 & -2 & -2 & -2 & -1.7 \\
\hline Reformer air compressor & -1.3 & -1.3 & -1 & 0 & 0 & -1.3 & -1.3 \\
\hline $\mathrm{CO}_{2}$ compressor & -0.9 & -0.9 & -0.8 & -2.9 & -2.9 & -0.9 & -0.9 \\
\hline Clean syngas compressor & -8.3 & -8.2 & -8.5 & -7.7 & -7.3 & -8.9 & -7.1 \\
\hline Recycle compressor & -0.2 & -0.2 & -0.2 & -0.2 & -0.2 & -0.2 & -0.2 \\
\hline Boiler air compressors & 0 & 0 & 0 & -2.2 & -2.1 & 0 & 0 \\
\hline misc & -8 & -8 & -8 & -8 & -8 & -8 & -8 \\
\hline Power Production, MW & & & & & & & \\
\hline Steam turbines & 31.5 & 33.5 & 29.2 & 54.8 & 54.6 & 31.7 & 32.2 \\
\hline Net Power Output, MW & 1.4 & -16.3 & -21.5 & 22.4 & 22.9 & 1.3 & 2.5 \\
\hline
\end{tabular}


Table 3.5. Equipment and Capitals Costs for Directly Heated Gasifier Based System Models

\begin{tabular}{|c|c|c|c|c|c|c|c|}
\hline Case & Base & B1 & $\mathrm{B} 2$ & B3 & $\mathrm{B} 4$ & B5 & B6 \\
\hline Case Description & Base & $\begin{array}{c}\text { Decreased } \\
\text { Gasifier } \\
\text { Pressure } \\
\text { (Syngas } \\
\text { Unchanged) }\end{array}$ & $\begin{array}{c}\text { Decreased } \\
\text { Gasifier } \\
\text { Pressure } \\
\text { (Syngas } \\
\text { Changed) }\end{array}$ & $\begin{array}{c}\text { No Steam } \\
\text { Reformer } \\
\text { Const. } \mathrm{H}_{2} \text {, } \\
\mathrm{CO} \text { partial } \\
\text { Pressures }\end{array}$ & $\begin{array}{c}\text { No Steam } \\
\text { Reformer } \\
\text { Constant } \\
\text { Total } \\
\text { Pressure } \\
\end{array}$ & $\begin{array}{c}\text { Double } \\
\text { Tar } \\
\text { Conc. }\end{array}$ & $\begin{array}{l}\text { One- } \\
\text { Half Tar } \\
\text { Conc. }\end{array}$ \\
\hline \multicolumn{8}{|l|}{ Installed Equipment Costs: } \\
\hline Air Separation Unit & 22.5 & 22.5 & 22.5 & 22.5 & 22.5 & 22.5 & 22.5 \\
\hline Feed prep \& drying & 27.6 & 24.4 & 24.4 & 27.6 & 27.6 & 27.6 & 27.6 \\
\hline Gasifier \& Cyclones & 106.2 & 106.1 & 106.2 & 106.2 & 106.2 & 106.5 & 105.7 \\
\hline Tar cracker & 4.6 & 4.6 & 4.5 & 4.6 & 4.6 & 4.5 & 4.8 \\
\hline Gasifier heat recovery & 0.6 & 0.5 & 0.5 & 0.6 & 0.6 & 0.6 & 0.6 \\
\hline Syngas compression & 1.6 & 15.7 & 15.0 & 1.7 & 1.7 & 1.7 & 1.6 \\
\hline Sulfur removal & 3.8 & 3.8 & 3.7 & 3.8 & 3.8 & 3.8 & 3.7 \\
\hline Steam Reformer (SR) & 17.0 & 16.8 & 14.5 & 0.0 & 0.0 & 16.9 & 16.9 \\
\hline Water Gas Shift (WGS) & 0.0 & 0.0 & 0.0 & 4.0 & 4.0 & 0.0 & 0.0 \\
\hline SR or WGS Heat Recovery & 4.1 & 3.7 & 3.5 & 0.8 & 0.7 & 3.8 & 3.7 \\
\hline SR or WGS $\mathrm{CO}_{2}$ compressor & 0.0 & 0.0 & 0.0 & 8.0 & 8.0 & 0.0 & 0.0 \\
\hline Amine $\mathrm{CO}_{2}$ removal & 20.1 & 19.7 & 19.3 & 21.9 & 21.9 & 20.2 & 20.0 \\
\hline Clean syngas compression & 4.1 & 4.0 & 4.1 & 3.9 & 3.7 & 4.3 & 3.8 \\
\hline Mixed alcohols synthesis & 25.3 & 24.1 & 27.0 & 33.6 & 30.9 & 21.9 & 26.8 \\
\hline Mixed alcohol recycle & 15.0 & 14.9 & 15.3 & 13.0 & 13.0 & 15.0 & 14.6 \\
\hline Mixed alcohol separations & 19.8 & 19.8 & 20.5 & 16.9 & 16.9 & 20.6 & 19.7 \\
\hline Steam sys \& power gen & 18.4 & 18.4 & 18.4 & 22.3 & 22.3 & 18.4 & 18.4 \\
\hline Remainder OSBL & 5.3 & 4.5 & 4.5 & 4.5 & 4.5 & 4.5 & 4.5 \\
\hline Total Installed, mm\$ & 296.0 & 303.6 & 304.1 & 295.9 & 292.7 & 292.7 & 295.0 \\
\hline Total Indirect, mm\$ & 151.0 & 154.8 & 155.1 & 150.5 & 149.3 & 149.3 & 150.4 \\
\hline Total Capital Inv, mm\$ & 447.0 & 458.4 & 459.3 & 446.4 & 442.0 & 442.0 & 445.4 \\
\hline
\end{tabular}

Table 3.6. Operating Costs for Directly Heated Gasifier Based System Models

\begin{tabular}{|c|c|c|c|c|c|c|c|}
\hline Case & Base & B1 & B2 & B3 & B4 & B5 & B6 \\
\hline Case Description & Base & $\begin{array}{c}\text { Decreased } \\
\text { Gasifier } \\
\text { Pressure } \\
\text { (Syngas } \\
\text { Unchanged) }\end{array}$ & $\begin{array}{c}\text { Decreased } \\
\text { Gasifier } \\
\text { Pressure } \\
\text { (Syngas } \\
\text { Changed) }\end{array}$ & $\begin{array}{c}\text { No Steam } \\
\text { Reformer } \\
\text { Const. } \mathrm{H}_{2} \text {, } \\
\mathrm{CO} \text { partial } \\
\text { Pressures }\end{array}$ & $\begin{array}{c}\text { No Steam } \\
\text { Reformer } \\
\text { Constant } \\
\text { Total } \\
\text { Pressure } \\
\end{array}$ & $\begin{array}{c}\text { Double } \\
\text { Tar } \\
\text { Conc. }\end{array}$ & $\begin{array}{c}\text { One- } \\
\text { Half Tar } \\
\text { Conc. }\end{array}$ \\
\hline \multicolumn{8}{|l|}{ Variable Costs, $\$ \mathrm{~mm} / \mathrm{y}$} \\
\hline Hybrid Poplar Chips & 25.330 & 25.330 & 25.330 & 25.330 & 25.330 & 25.330 & 25.330 \\
\hline Olivine makeup & 1.767 & 1.767 & 1.767 & 1.767 & 1.767 & 1.767 & 1.767 \\
\hline Ash disposal & 1.003 & 1.003 & 1.003 & 1.003 & 1.003 & 1.003 & 1.003 \\
\hline Misc Chemicals & 2.269 & 2.184 & 2.326 & 1.724 & 1.726 & 2.372 & 2.121 \\
\hline Tar Reformer Catalyst & 0.454 & 0.437 & 0.465 & 0.345 & 0.345 & 0.474 & 0.424 \\
\hline Mixed Alcohols Catalyst & 0.142 & 0.135 & 0.151 & 0.182 & 0.182 & 0.121 & 0.150 \\
\hline Wastewater treatment & 1.134 & 1.223 & 0.991 & 0.813 & 0.814 & 1.136 & 1.214 \\
\hline Cooling water & 2.310 & 2.550 & 1.922 & 1.806 & 1.808 & 2.336 & 2.478 \\
\hline Natural gas & 0.000 & 0.000 & 0.000 & 0.000 & 0.000 & 0.237 & 0.000 \\
\hline Electricity & -0.739 & 8.659 & 11.402 & -11.911 & -12.098 & -0.679 & -1.349 \\
\hline Propanol + Credit $^{\mathrm{a}}$ & -62.786 & -60.416 & -64.406 & -47.892 & -47.922 & -65.654 & -58.698 \\
\hline Total Variable, $\$ \mathrm{~mm} / \mathrm{yr}$ & -29.116 & -17.128 & -19.047 & -26.832 & -27.044 & -31.555 & -25.559 \\
\hline Fixed Costs, \$mm/yr & 20.021 & 20.399 & 20.426 & 20.006 & 19.856 & 19.855 & 19.966 \\
\hline Depreciation (5\%/yr), \$mm/yr & 22.352 & 22.921 & 22.963 & 22.321 & 22.102 & 22.101 & 22.268 \\
\hline Gen \& Admin, \$mm/yr & 6.355 & 6.971 & 7.088 & 5.686 & 5.634 & 6.329 & 6.311 \\
\hline ROI (10\%/yr), \$mm/yr & 44.704 & 45.843 & 45.925 & 44.643 & 44.204 & 44.203 & 44.536 \\
\hline EtOH Production, mmgal/yr & 45.377 & 43.679 & 46.523 & 34.488 & 34.527 & 47.450 & 42.421 \\
\hline Total Variable, \$/gal EtOH & -0.642 & -0.392 & -0.409 & -0.778 & -0.783 & -0.665 & -0.603 \\
\hline Fixed Costs, $\$ /$ gal EtOH & 0.441 & 0.467 & 0.439 & 0.580 & 0.575 & 0.418 & 0.471 \\
\hline Depreciation, \$/gal EtOH & 0.493 & 0.525 & 0.494 & 0.647 & 0.640 & 0.466 & 0.525 \\
\hline Gen \& Admin, \$/gal EtOH & 0.140 & 0.160 & 0.152 & 0.165 & 0.163 & 0.133 & 0.149 \\
\hline ROI, \$/gal & 0.985 & 1.050 & 0.987 & 1.294 & 1.280 & 0.932 & 1.050 \\
\hline Est. Selling Price \$/gal & 1.417 & 1.809 & 1.663 & 1.909 & 1.875 & 1.284 & 1.592 \\
\hline
\end{tabular}




\subsubsection{Case B1. Gasifier Pressure Decreases and Sygnas Compositions are Unchanged}

Case B1 examines the effect of decreasing the gasifier pressure on system performance and cost. The syngas compositions are assumed to be the same as those used in the Base Case for a 330 psia operating pressure. Decreasing the gasifier pressure to 20 psia leads to several modifications to the overall process. The $\mathrm{CO}_{2}$ pressurized lock hopper used in the Base Case for sending feedstock into gasifier is no longer needed. Low-pressure steam at 35 psi replaces high-pressure steam injected into the gasifier. The oxygen compressor in the air separation unit is also no longer needed. Because low-pressure syngas is generated, the raw syngas compressor is changed from a single stage to a multiple stage unit with intercooling to compress raw syngas from 15 to 417 psi.

Performance Results. In Case B1, the raw syngas compositions are assumed to be unchanged at the lower gasifier pressure and thus this case has the same $\mathrm{H}_{2}: \mathrm{CO}$ ratio and char production as the Base Case. However, the $\mathrm{CO}_{2}$ content in the raw syngas is lower than that of Base Case since there is no lock hopper pressurized by $\mathrm{CO}_{2}$. Thus, all other syngas components are slightly higher than the Base Case. For the same reason, the flow rate of scrubbed dry raw syngas is lower than that of Base Case.

Case B1 has the same gasifier steam injection rate as the Base Case. However, because of the lower $\mathrm{CO}_{2}$ content, the WGS reaction produces a lower $\mathrm{CO}$ content and a higher $\mathrm{H}_{2}$ content in the clean syngas, resulting in a slightly higher $\mathrm{H}_{2}: \mathrm{CO}$ ratio. The clean syngas flow rate and $\mathrm{CO}$ concentration in this case is lower than that of the Base Case, thus resulting in reduced mixed alcohol yields.

The differences in power consumption stems from two processes: 1) the air separation unit and 2) the raw syngas compressor. Because the gasifier pressure is low, no $\mathrm{O}_{2}$ compressor is needed in the air separation unit, therefore, the net power consumption for the unit is less when compared to that in the Base Case. However, the raw syngas compressor power consumption is much greater than that of the Base Case because the raw syngas compressor now must increase the syngas pressure from 15 to 417 psi, while in Base Case, the pressure change differential is less (i.e., from 324 to 417 psi). The amount of power generated by the steam turbine in this case is higher than in the Base Case because low-pressure steam is used in the gasifier, while in the Base Case, high-pressure steam is used. The net power output is significantly reduced in Case $B 1$ because of the increased power requirements of the raw syngas compressor is so much greater than the increased power generation by the high-pressure steam turbine.

Economic Effects. Decreasing the gasifier pressure leads to a decrease in the gasification capital costs mainly because the lock-hopper compressor is eliminated from the process. However, the raw gas compressor cost increases nearly sevenfold. The total installed cost for Case B1 is about 3\% higher than that of the Base Case. The large amount of power needed for the raw syngas compressor results in a switch from export power to import power. The increased variable and capital costs, along with a decreased ethanol yield, results in an increased ethanol selling cost of \$0.39/gal.

Model Limitations. The cost model for the high-pressure, directly heated gasifier (based on Hamelinck and Faaij [2002]) is used in this case for estimating the low-pressure gasifier cost. Thus, the impact of the pressure decrease on the gasifier cost is not considered because of a lack of reference data. In general, lowering the gasification pressure should lower the capital cost for the gasifier. However, it is likely that a low-pressure gasifier will require a longer residence time, thus resulting in a larger size. This may eliminate the savings from reducing the reactor wall thickness required for high-pressure operation. 
Another limitation is that the air separation unit cost is a single value that includes the price of an $\mathrm{O}_{2}$ compressor. No separate cost model was developed for the $\mathrm{O}_{2}$ compressor. Therefore, the installed cost for the air separation unit is overestimated for this case. This limitation can be solved by developing a more detailed air separation unit cost model that includes the cost for each main component. However, the impact of this limitation is minor compared to other costs in the system. Lastly, this case assumes that the raw syngas composition is unaffected by the gasifier operating pressure. This limitation is addressed in Case B2.

Analysis. Assuming that the syngas composition is unchanged, decreasing the gasifier pressure leads to higher production costs. This is mainly the result of higher capital and operating costs for the raw syngas compressor and decreased revenue from export power that cannot be compensated for by cost savings in feedstock feeding and $\mathrm{O}_{2}$ compression.

\subsubsection{Case B2. Gasifier Pressure Decreases and Sygnas Compositions are Changed}

Case B2 also examined the effects of decreasing the gasifier pressure on system performance and cost, but with allowances for raw syngas composition changes with pressure. The gasifier pressure is reduced to $20 \mathrm{psi}$, while maintaining the Base Case temperature (i.e., $1600^{\circ} \mathrm{F}$ ). The syngas composition is adjusted for the lower pressure by using the correlations published by Eggeman (2005). Because the gasifier operates at low pressure, the pressurized lock hopper and the multiple-stage oxygen compressor is eliminated and low-pressure steam (35 psi) is used. The raw syngas compressor is changed to a multiplestage compressor with intercooling to meet the raw syngas compression requirements.

Performance Results. The raw syngas of Case $\mathrm{B} 2$ has less $\mathrm{H}_{2}, \mathrm{CO}_{2}$, and $\mathrm{CH}_{4}$, but more $\mathrm{CO}, \mathrm{H}_{2} \mathrm{O}$, tar, and $\mathrm{C}_{2+}$ than that of the Base Case. Case B1 also has much lower $\mathrm{H}_{2}: \mathrm{CO}$ ratio and the char production in this case is about half. The scrubbed dry raw syngas flow rate is comparable to that of the Base Case, but the total $\mathrm{CO}$ and $\mathrm{H}_{2}$ flow rates in the raw syngas is higher. Because the raw syngas in Case $B 2$ has a much lower $\mathrm{H}_{2}$ : $\mathrm{CO}$ ratio than that in the Base Case, more steam is used in the steam reformer to increase the $\mathrm{H}_{2}$ : $\mathrm{CO}$ ratio to $\sim 1.2$. The clean syngas flow rate is higher than that of the Base Case, leading to a higher mixed alcohol yield.

The electric power generation for this case is lower than that of both Case B1 and the Base Case. As in Case B1, the power consumption of the air separation unit is lower than that of Base Case because the oxygen compressor is eliminated. However, the power consumption of the raw syngas compressor is much higher than that of Base Case because of the low pressure of the inlet raw syngas. Power consumption for the raw syngas compressor also is slightly higher than that of Case Bl because the raw syngas has more water and thus a higher flow rate than in Case B1. The steam turbine power generation is lower than both the Base Case and Case B1. Although low-pressure steam is used in the gasifier, the increase in high-pressure steam consumption in the steam reformer reduces the available steam used for power generation. Reduced char production in the gasifier reduces the heat from the exhaust gas of the combustor; therefore, a greater fraction of the purge gas from the alcohol synthesis process is used in the feed stock dryer, leaving less fuel gas for the gas turbine power generation.

Economic Effects. The total capital investment for Case B2 is almost the same as for Case B1, with higher equipment costs for alcohol synthesis and purification and lower equipment costs for raw syngas compression, purification, and conditioning. The total decrease in power-generation credits for Case B2 
relative to Case $B 1$ are more than offset by a significant increase in byproduct credits attributed to the higher mixed alcohol yields. However, the increased byproduct credits do not offset the increased raw syngas compression costs for this case. The net result is a production cost that is higher than the Base Case.

Model Limitations. The cost estimation limitation for the low-pressure gasifier and the air separation unit analyzed in Case BI also applies to this case. The syngas compositions were estimated using the correlations developed by Eggeman (2005), which covered a pressure range from 84 to 345 psia. It was assumed that this correlation could be extrapolated down to 20 psi.

Analysis. Case B2 showed that while the effects of changing pressure on the composition of the gas had a beneficial effect on the ethanol selling price, the impact of having to pressurize the raw syngas from 20 to 417 psia instead of from 330 to 417 psia is the dominant factor affecting the selling price as was shown in the previous case. Thus, it appears that high-pressure operation of the gasifier is the preferred case.

\subsubsection{Case B3. Methane/Ethane are not Reformed and the Clean Syngas Pressure is Changed}

Case B3 investigated the effects of not reducing the syngas methane and ethane concentrations by steam reforming to determine the effect of eliminating the capital and operating costs of a steam reformer against the expected loss of mixed alcohols yield. The total pressure of the clean syngas was increased to maintain the same $\mathrm{H}_{2}$ and $\mathrm{CO}$ partial pressures as in the Base Case. A reverse WGS reactor is used in place of the steam reformer to adjust the $\mathrm{H}_{2}$ :CO ratio in the scrubbed gas to the desired synthesis gas ratio of 1.2:1. The methane and ethane are inert in the reverse WGS reaction. The reverse WGS reactor is assumed to be similar to a standard high-temperature shift reactor, except that compressed $\mathrm{CO}_{2}$ is substituted for steam and the reactor outlet temperature is lower than the inlet temperature. The inlet temperature is limited to $725^{\circ} \mathrm{F}$ to keep the temperature within the upper bounds of a standard WGS reactor. The clean syngas pressure is increased to $2164 \mathrm{psi}$ (2159 psig in the alcohol synthesis reactor) to maintain the same partial pressure of $\mathrm{H}_{2}$ and $\mathrm{CO}$ as the Base Case. Because methane and ethane are not reformed, the synthesis gas recycle loop purge gas contains larger amounts of light hydrocarbons that are then used for power generation. A gas-fired boiler and superheater are added into the steam cycle to combust the extra purge gas and generate high-pressure steam for power generation.

Performance Results. The raw syngas compositions for Case B3 are the same as for the Base Case because there are no modifications to the gasifier. The clean syngas from the $\mathrm{CO}_{2}$ removal unit has a much lower flow rate than that in the Base Case because no steam reforming of methane and ethane in the scrubbed syngas to $\mathrm{H}_{2}$ and $\mathrm{CO}$ occurred, which would have increased the total molar flow rate of the clean syngas. The reduced flow of $\mathrm{CO}$ and $\mathrm{H}_{2}$ resulted in a $24 \%$ reduction in the mixed alcohol yield compared to that for the Base Case.

While the clean syngas must be compressed to a higher pressure to maintain the same syngas $\mathrm{H}_{2}$ and CO partial pressures as in the Base Case, the lower syngas flow rate results in a $7 \%$ decrease in the compressor power requirements. However, the lower compression duty for the clean synthesis syngas is offset by the higher compression duty for the larger synthesis recycle gas flow. 
Replacing the steam reformer with a reverse shift reactor slightly increases the power demand. The steam reformer only needed air blowers for the burners, while the shift reactor needs $\mathrm{CO}_{2}$ compression. The $\mathrm{CO}_{2}$ feed to the reverse WGS reactors is compressed from nearly atmospheric pressure to the WGS pressure. The increased $\mathrm{CO}_{2}$ to the reverse WGS reactor also increases the $\mathrm{CO}_{2}$ removal capacity requirements for the amine scrubber. Additional compression is needed for the air fans associated with the boiler and superheater in the steam cycle. However, these increases in power demand are more than offset by the large increase in power produced because of the increased amount of methane and ethane in the off-gas.

Economic Effects. The replacement of the steam reformer with a reverse shift reactor and $\mathrm{CO}_{2}$ compressor (and added amine scrubber capacity) saves approximately $\$ 13$ million in capital investment for gas conditioning. However, the mixed alcohol synthesis reactor operates at a higher pressure, and has higher throughput, which leads to an $\$ 8$ million cost increase. This cost increase is partially offset by reduced clean syngas flow to the synthesis reactor and lower alcohol separation cost because of the lower flow rates. Although the synthesis reactor recycle rate is higher than for the Base Case, the capital cost is lower because of the high-pressure amine system in the recycle loop. Case $B 4$ has less $\mathrm{CO}_{2}$ to remove from the recycle because of the lower yields. Adding a boiler and superheater to the steam cycle also increases the investment. The total project investment of Case B3 is less that $1 \%$ lower than that for the Base Case.

Because more fuel gas is directed to the power generation unit, electric power export is increased by $15 \%$ over the Base Case; however, the byproduct yield reduces the byproduct credit by about $24 \%$. The net annual production cost for Case B3 is slightly higher than for the Base Case. When this increased production cost is coupled with lower yields, the resulting unit price of ethanol is about $35 \%$ higher than that for the Base Case.

Model Limitations. It is assumed that a conventional high-temperature shift catalyst can be made to perform a reverse shift reaction by substituting $\mathrm{CO}_{2}$ for steam and using a high inlet reactor temperature. The cost of the high-pressure amine system in the synthesis recycle loop is based on the amount of $\mathrm{CO}_{2}$ removed. Pressure effects, either in terms of cost or separation efficiency, are not taken into account. Hence, the capital cost for the amine system is probably low relative to that for the Base Case.

Analysis. Replacement of the steam reformer with a less expensive reverse shift reactor and increased power production cannot overcome the significant yield loss associated with methane and ethane as non-reactants in the synthesis step. Therefore, this scenario is not preferred because of its low carbon efficiency. The steam reformer cannot be eliminated or replaced by a shift reactor unless the gasifier can be made to produce low-methane syngas.

\subsubsection{Case B4. Methane/Ethane are not Reformed and Clean Syngas Pressure is Unchanged}

Case B4 differs from Case B3 in that the clean syngas pressure (i.e., mixed alcohol synthesis pressure) stays the same as in the Base Case. Otherwise, the same process changes are made as in the Case $B 3$. The steam reformer is replaced by a reverse shift reactor as a means of adjusting the $\mathrm{H}_{2}: \mathrm{CO}$ ratio. This variation on Case B4 isolates the synthesis pressure effect on overall costs. 
Performance Results. Case B4 has the same raw gas and clean syngas compositions as that of Case B3. Therefore, this case also has similar lower final product yields than the Base Case. In this case, the clean syngas pressure is the same as the Base Case pressure of 2000 psi. Therefore, the clean syngas compressor power consumption for Case B4 is slightly lower than that of Case B3, and is partially offset by small increases in the power requirements for the boiler air and recycle compressor. Electric power production is the same as for Case B3 because of the high concentration of methane and ethane in the off-gas.

Economic Effects. The capital cost for Case B4 is lower than those for both the Base Case and Case B3. The difference between the capital costs for Case B3 and Case B4 is the cost for the mixed alcohols synthesis step, which is about $4 \mathrm{~mm} \$$ and is accounted for by the pressure difference. Eliminating the steam reformer and having a reduced synthesis reactant partial pressure is worth about $5 \mathrm{~mm} \$$ over the Base Case. However, the changes in capital-related and operating costs do not compensate for the $24 \%$ reduction in the mixed alcohol yields for Case B4 so that the price of ethanol in Case B4 is only about 2\% lower than for Case B3 and about 32\% higher than for the Base Case.

Model Limitations. In this case, the partial pressure of $\mathrm{CO}$ and $\mathrm{H}_{2}$ in the clean syngas is lower than that for either the Base Case or Case B3. The mixed alcohol synthesis model does not consider the impact of the different $\mathrm{CO}$ partial pressures on the $\mathrm{CO}$ conversion efficiency or selectivity on different mixed alcohol products. The limitations to the high-pressure amine system noted for Case B3 also apply.

Analysis. The reduction in capital costs resulting from eliminating the steam reformer and increasing electricity sales cannot overcome the poor yields associated with the increased amounts of methane and ethane in the clean syngas. The difference in syngas partial pressure between Case B3 and Case B4 are insignificant within the bounds of the model limitations.

\subsubsection{Case B5. Tar Production is Assumed to be 1.5 Times that of the Base Case}

Case B5 investigated the impact of increasing the tar content in the syngas on the overall system performance and cost. As in Case A5, this case is motivated by the uncertainty in the reported tar concentrations in raw gas for the various gasifiers because of differences in the methods used to quantify them. It is not intended to suggest increasing or decreasing the tar content intentionally.

In this case, the tar production estimated by the Eggeman model (Eggeman 2005) is increased by 50\% of its predicted value. The syngas concentrations and rates are the same as in the Base Case. The char production decreases to balance the increased $\mathrm{C}$ and $\mathrm{H}$ components in tar. This is a different calculation method than that used in Case $A 5$ and Case $A 6$ in which the syngas decreased in response to additional tar formation, while the total char rate was held constant. The indirectly heated gasifier produces much more char than tar, and it is possible to compensate for extra tar production by adjusting the char composition. The directly fired gasifier produces much more tar and less char than the indirectly fired gasifier. It is not possible to balance the difference in tar production by changing the char composition while keeping the rate of char production the same as the Base Case.

Steam injection to the gasifier is increased to reach the heat balance for the gasification process. Because of decreased char production, natural gas is sent to the combustor to provide additional heat for feedstock preheating. In addition, a small amount of natural gas also is added to the fuel gas used for 
feedstock drying. The recycle ratio of mixed alcohol synthesis is decreased to meet the fuel gas requirement by stream reforming and other processes.

Performance Results. Compared to the Base Case, Case B5 has higher syngas moisture content resulting from increased steam injection. Char production in this case is much lower than the Base Case because of the increase in tar production. The scrubber dry raw syngas flow rate is higher than the Base Case because more tar is produced and converted into $\mathrm{H}_{2}$ and $\mathrm{CO}$ in the tar reformer. For the same reason, the clean syngas flow rate in Case B5 is more than that of the Base Case by 8\%. This results in about a 5\% increase in the mixed alcohol production rate over the Base Case. This case also has a lower synthesis gas recycle ratio; that is, $94 \%$ of the gas is recycled compared with $96 \%$ for the Base Case. The ethanol yield is $2 \mathrm{mmgal} / \mathrm{yr}$ more than that for the Base Case.

Because of the higher syngas flow rate, the power consumption for the raw syngas compressor and clean syngas compressor are higher than those for the Base Case. This is offset by slightly lower power consumption for the combustor air compressor compared to that for the Base Case because the char production is lower, and thus the required air flow for char combustion is also lower. The net power output for Case B5 is slightly lower than that for the Base Case.

Economic Effects. Compared to the Base Case, Case B5 has a slightly lower total installed equipment cost. This is mainly attributed to a $\$ 4$ million reduced cost for the synthesis reactor, which is smaller because the recycle ratio for the alcohol synthesis in Case B5 is lower than that for the Base Case. The higher production rate of mixed alcohols results in an approximately $9 \%$ reduction in the selling price of ethanol.

Model Limitations. The model results are limited by not knowing how increased tar production affects the char and syngas compositions. The product yield may be artificially inflated by the reduced char production. Another limitation is in the equipment cost estimation for the gasifier and tar cracker. The increased tar production may increase the cost of gasifier, but the current cost model is based on the inlet biomass flow rate and does not consider the impact of different tar generation. The tar cracker cost is calculated based on the volume flow of inlet syngas. The effect of increased tar flow rate on residence time and tar reformer size is not reflected in the model. It also is assumed that increased tar yields do not cause increased fouling problems in any of the downstream equipment.

Analysis. The main reason for the production cost decrease is the increase in carbon efficiency and, thus, the increase in final products.

\subsubsection{Case B6. Tar Production is Assumed to be Half that of the Base Case}

Case B6 investigates the impacts of lower tar content in the syngas. In this case, the tar production is half that predicted by the Eggeman correlation (Eggeman 2005). The char production is increased to balance the decrease in $\mathrm{C}$ and $\mathrm{H}_{2}$ components in tar. This is similar to the method used in Case B5, and differs from the method used in Case A6 for the reasons already explained. Steam injection to the gasifier is the same as that used for the Base Case.

Performance Results. Compared to the Base Case, halving the tar content almost doubles char production. Because of the lower tar production and the higher $\mathrm{C}$ and $\mathrm{H}$ content in the char, less $\mathrm{H}_{2}$ and $\mathrm{CO}$ is produced from tar reforming; thus, the raw syngas flow rate of Case B6 is lower than that of the 
Base Case. For the same reason, the clean syngas flow rate in Case B6 is lower than that of the Base Case by $8 \%$. Because no extra fuel gas is needed for biomass drying, more syngas is recycled for alcohol synthesis than in the Base Case. However, the lower clean syngas flow rate leads to lower yields. The carbon efficiency of Case B6 is lower than that of the Base Case because more $\mathrm{C}$ and $\mathrm{H}$ went to the char and was unavailable for synthesis.

The increased char in the char combustor supplies sufficient exhaust heat to dry the biomass without addition of an extra heat source. Thus, there is no blower power associated with the dryer. The power consumption for the combustor air compressor of Case B6 is slightly higher than that of Base Case because char production is higher and more air is required for combustion. The power consumption levels for the raw syngas compressor and clean syngas compressor in Case B6 are lower than those of the Base Case. The char combustor supplies sufficient heat to the dryer without addition of fuel gas. Because no fuel gas is needed for the dryer, more fuel gas from the synthesis process is available for steam generation than in the Base Case. Thus, the steam turbine power generation for Case B6 is slightly greater than that of Base Case. The net power output for Case B6 also is higher than for the Base Case.

Economic Effects. The total capital investment for Case B6 is slightly less than that for the Base Case. The mixed alcohol synthesis reactor installed-equipment cost is higher than that for the Base Case, even though the yields are lower. This is because of the increased recycle around the synthesis reactor and the resulting build up of inert materials in the recycle loop.

The lower alcohol byproduct yields resulted in significantly lower byproduct credits that were only partially offset by increased electricity generation. Similarly, the decreased ethanol yield resulted in a further increase in the per-gallon cost of ethanol. The net production cost for Case B6 is about 12\% higher than that of the Base Case.

Model Limitations. The main model limitations for Case B6 are the same as noted for Case B5.

Analysis. Although the method used to adjust the tar content was different for the direct gasifier than for the indirect gasifier, both methods showed the same trend, albeit to a different degree. Increased tar formation might lead to increased product yields and, therefore, lower production costs. Decreased tar yields produce the opposite trend. 


\subsection{Conclusions}

The conclusions drawn from analyses and simulation results derived from these investigations are presented on this chapter.

The process economics are improved for both gasifier configurations when the gasifier is operated at elevated pressures (nominally 150 to $300 \mathrm{psig}$ ). This improvement is attributed primarily to a significant reduction in the compression capital and operating costs for the raw product gas fed to the LoCAT sulfurremoval system. Specifically, the volume of the product gas is much larger than the volume of the gases that require compression before entering the gasifiers (i.e., compressed $\mathrm{CO}_{2}$ to the feedstock lock hoppers, pressurized air to the combustor [indirectly heated gasifier], and oxygen to the gasifier [directly heated gasifier]). Increases in the capital cost to pressurize the gasifier systems are much lower that the capital cost savings for the product-gas compressor.

The process economics for both gasifier systems are dominated by the efficiency of converting biomass to $\mathrm{CO}$ and $\mathrm{H}_{2}$. This was shown when examining the possible benefits of eliminating the methane reforming process and altering the amount of tar in the raw product gas. In the case of eliminating the methane reformer, both capital and annual operating costs were reduced for the integrated system using both gasifier configurations. However, this was accompanied by a reduced annual production of mixed alcohols because less syngas was produced due to unconverted methane in the clean syngas. This residual methane ultimately was burned as fuel to produce power and process heat, which are less valuable commodities than the mixed alcohols. A reduction in the mixed alcohol yield results in an increase in the unit cost of mixed alcohols.

In the case of the tar content of the product gas, it was found that the amount of tar in the gas was not itself important because the cracking process would convert the tar to syngas. A more important consideration was whether reducing (or increasing) the tar content in the raw gas was accomplished by changing the amount of char produced in the gasifier. In the current models, char produced in the gasifiers is ultimately combusted to produce process heat for the integrated systems, and possibly electrical power. More importantly, char is not converted into syngas, thereby reducing the amount of mixed alcohol produced by the integrated systems. The net effects of the increased char production that resulted from decreased tar production were minor changes in the capital and annual operating costs, accompanied by a decrease in mixed alcohol production so that the unit price of mixed alcohols would increase.

The manner in which a gasifier is operated and the resulting composition of the raw gas leaving the gasifier also can impact the economics of mixed alcohol production. This was illustrated in Case Al in which the gasifier operating conditions were altered to produce a raw product gas with a much higher $\mathrm{H}_{2}$ :CO ratio. To accomplish this, a higher volume of raw gas was produced in the gasifier containing less methane and more $\mathrm{H}_{2}, \mathrm{CO}$, and $\mathrm{CO}_{2}$, thereby increasing the subsequent compression costs. In addition, additional steam was required, thus increasing the volume of wet product gas passing through the cyclones. However, the $\mathrm{H}_{2}$ : $\mathrm{CO}$ ratio required for alcohol synthesis was much lower than that produced by the gasifier, so reverse WGS was required, accompanied by compression and addition of recycle $\mathrm{CO}_{2}$ to the WGS reactor, which significantly increased the operating costs. In this particular case, the net effect on costs was increased capital costs and lower net electric power generation, without any significant change in the mixed alcohol production rate. However, if the gasifier had been operated in a manner that 
did not require reverse WGS to adjust the $\mathrm{H}_{2}$ :CO ratio downward, it may have been possible to reduce net costs. Alternatively, the $\mathrm{H}_{2}$ : $\mathrm{CO}$ ratio requirements of the alcohol syntheses reactor are important because they establish the amount of steam and/or $\mathrm{CO}_{2}$ that needs to be added to the methane reformer to obtain the correct $\mathrm{H}_{2}$ : $\mathrm{CO}$ ratio.

In summary, the alternative cases evaluated in this study point to the potential importance of operating the gasifier at elevated pressure, and minimizing gasifier products that ultimately lead to decreased production of $\mathrm{H}_{2}$ and $\mathrm{CO}$ in the clean syngas, specifically char production in the gasifiers, the amount of unconverted tar in the tar cracker, and the amount of unconverted methane leaving the methane reformer. Consideration also should be given to operating the gasifier in a manner that best matches the $\mathrm{H}_{2}$ :CO requirements of the alcohol synthesis reactor without requiring significant forward or reverse WGS in the methane reforming/WGS reactor. 


\subsection{References}

Aden A, P Spath, and A Atherton. 2005. "The Potential of Thermochemical Ethanol via Mixed Alcohol Production.” Milestone Completion Report. FY05-684. October 2005.

Bechtel. 1998. Base Design/Economics for Advanced Fischer-Tropsch Technology. DE-AC2291PC90027-0,1, Final Report for the U.S. Department of Energy, Washington, D.C.

Chemical Engineering Magazine. 2007a. "Economic Indicators: Chemical Engineering Plant Cost Index January 2007 Final.” Chemical Week Associates, New York, 114(5):96.

Chemical Engineering Magazine. 2007b. "Economic Indicators: Chemical Engineering Plant Cost Index February 2007 Final.” Chemical Week Associates, New York, 114(6):84.

Chemical Engineering Magazine. 2007c. "Economic Indicators: Chemical Engineering Plant Cost Index March 2007 Final." Chemical Week Associates, New York, 114(7):84.

Courty P, P Chaumette, C Raimbault, and P Travers P. 1990. "Production of Methanol-Higher Alcohol Mixtures from Natural Gas via Syngas Chemistry." Revue de l'Institut Francais du Petrole 45(4):561-78.

Eggeman T. 2005. "Updated Correlations for GTI Gasifier - WDYLD8." Technical memorandum for Pam Spath, National Renewable Energy Laboratory, Golden, Colorado. June 27, 2005.

Evans RJ, RA Knight, M Onischak, and SP Babu. 1988. Development of Biomass Gasification to Produce Substitute Fuels. Institute of Gas Technology for Pacific Northwest Laboratory, PNL-6518, Richland, Washington.

Forzatti P, E. Tronconi. and I Pasquon. 1991. "Higher Alcohol Synthesis." Catalysis Reviews-Science and Engineering 33(1-2):109-168.

Hamelinck C and A Faaij. 2002. "Future Prospects for Production of Methanol and Hydrogen from Biomass." Journal of Power Sources 111(1):1-22.

Hamelinck C, A Faaij, H den Uil, and H Boerrigter. 2003. "Production of FT Transportation Fuels from Biomass; Technical Options, Process Analysis and Optimixation and Development Potential." NWS 90393-3342-4. Utrecht University, Utrecht, The Netherlands.

Herman RG. 1991. "Chapter 7 - Classical and Non-Classical Routes for Alcohol Synthesis." New Trends in CO Activation, L Guczi, ed., pp 265-349, Elsevier, New York.

Hofbauer, H and R Rauch. 2001. Hydrogen-Rich Gas from Biomass Steam Gasification. Publishable Final Report, Research Funded by the European Commission, Contract No. JOR3CT970196, Institute of Chemical Engineering Fuel and Environmental Technology, Getreidemark 9/159, A-1060 Wien, Austria.

Hofbauer, H., R. Rauch, B. Klaus, K, Reinhard, and A. Christian. 2002. "Biomass CHP Plant Gussing A Success Story." Presented at the Expert Meeting on Pyrolysis and Gasification of Biomass and Waste; October 2002, Strasbourg, France. 
Hutchings GJ, RG Copperthwaite, and NJ Coville. 1988. "Catalysis for Hydrocarbon Formation and Transformations." South African Journal of Science 84(1):12-16.

Merichem. 2008. Lo-Cat process. Available at http://www.gtp-merichem.com/products/locat/diagrams/process.php.

Naqvi S. 2000. Opportunities for Gas-to-Liquid Technologies. SRI Consulting Process Economic Program, Stanford Research Institute. Menlo Park, California.

National Energy Technology Laboratory (NETL). 1998a. Texaco IGCC Base Case. PED-IGCC-98-001, Process Engineering Division, revision dated June 2000. Available at http://www.netl.doe.gov/technologies/coalpower/turbines/refshelf/igcc-h2-sygas/texac3y.pdf.

National Energy Technology Laboratory (NETL). 1998b. Shell IGCC Base Case. PED-IGCC-98-002, Process Engineering Division, revision dated June 2000. Available at http://www.netl.doe.gov/technologies/coalpower/gasification/pubs/pdf/system/shell3x_.pdf.

National Energy Technology Laboratory (NETL). 1998c. Destec IGCC Base Case. PED-IGCC-98-003, Process Engineering Division, revision dated June 2000. Available at http://www.netl.doe.gov/technologies/coalpower/gasification/pubs/pdf/system/destx3x_.pdf.

Nexant Inc. 2006. Equipment Design and Cost Estimation for Small Modular Biomass Systems, Synthesis Gas Cleanup, and Oxygen Separation Equipment. Task 9: Mixed Alcohols From Syngas State of Technology. Subcontract Report NREL/SR-510-39947, May 2006, San Francisco, California. Available at http://www.nrel.gov/docs/fy06osti/39947.pdf.

Peters MS and KD Timmerhaus. 2003. Plant Design and Economics for Chemical Engineers. $5^{\text {th }}$ Edition, McGraw-Hill, Inc., New York.

Wang S (editor). 2003. PEP Yearbook International. Volume 1E. 2003. SRI Consulting Process Economic Program, Menlo Park, California. Available at http://www.sriconsulting.com/PEP/.

Phillips S, A Aden, J Jechura, and D Dayton. 2007. Thermochemical Ethanol Via Indirect Gasification and Mixed Alcohol Synthesis of Lignocellulosic Biomass. NREL/TP-510-41168. National Renewable Energy Laboratory, Golden, Colorado.

Quarderer GJ. 1986. "Mixed Alcohols from Synthesis Gas." Presented at the 78th National AICHE Meeting, April 1986, New Orleans, Louisiana.

Spath P, A Aden, T Eggerman, M Ringer, B Wallace, and J Jechura. 2005. "Biomass Hydrogen Production Detailed Design and Economics Utiltizing the Battelle Columbus Laboratory Indirectly Heated Gasifier.” NREL/TP-510-37408, National Renewable Energy Laboratory, Golden, Colorado. Ullmann's Encyclopedia of Industrial Chemistry. $7^{\text {th }}$ Edition. John Wiley \& Sons, Inc. 30 Aug 2007. Wong SF, MS Patel, and DA Storm. 1986. "Retrofitting Methanol Plants for Higher Alcohols." 78th American Institute of Chemical Engineers, National Meeting, New Orleans, Louisiana. 
Appendix A

\section{Equipment Cost Details}





\section{Appendix A}

\section{Equipment Cost Details}

The costing methods for non-standard and packaged equipment are described below:

1. Gasifier and Tar Cracker. The gasifier cost is a function of the dry biomass feed rate, while the tar cracker cost is a function of the syngas standard volumetric flow rate. Pressure effects and residence time effects are not included.

2. Alcohol Synthesis Reactor. The mixed alcohol reactor is assumed to be a shell-and-tube reactor, with catalyst in the tubes and steam raised in the shell. The catalyst volume is determined from the gas hourly space velocity ( $3000 \mathrm{vol}_{\mathrm{Gas}} / \mathrm{hr} / \mathrm{vol}_{\mathrm{cat}}$ for the Base Case) and the gas volume flow rate at standard conditions as determined from the heat and material balance. A $100-\mathrm{ft}$ tube length is assumed with an allowance above and below the catalyst bed. This is similar to the FT design as provided by Naqvi (2000). The tube diameter is adjusted within a range of 2 to $4 \mathrm{in}$. to achieve a reasonable length-to-diameter $(\mathrm{L} / \mathrm{D})$ ratio. The number of tubes is determined by dividing the total reactor length by the tube length. The shell diameter is found by assuming a 3-in. tube spacing and square pitch. The costs of the shell and tubes are estimated separately using ASPEN Icarus, and then added to estimate the total reactor cost.

3. Shift Reactor. The shift reactor is assumed to be an adiabatic, fixed-bed reactor with a gas hourly space velocity of $3000 \mathrm{Nm}^{3} / \mathrm{m}^{3}$ catalyst $/ \mathrm{h}$ and an $\mathrm{L} / \mathrm{D}$ ratio of 3 .

4. Air Separation Unit. Data reported in the literature for cryogenic air separation plants are shown below. The regression correlation used in this report is shown on the chart. The data used in the correlation were developed from various reports (NETL 1998; Naqvi 2000; Bechtel 1998). Data from Hammelinck (2000), shown as "a," "b," "c" are shown for comparison.

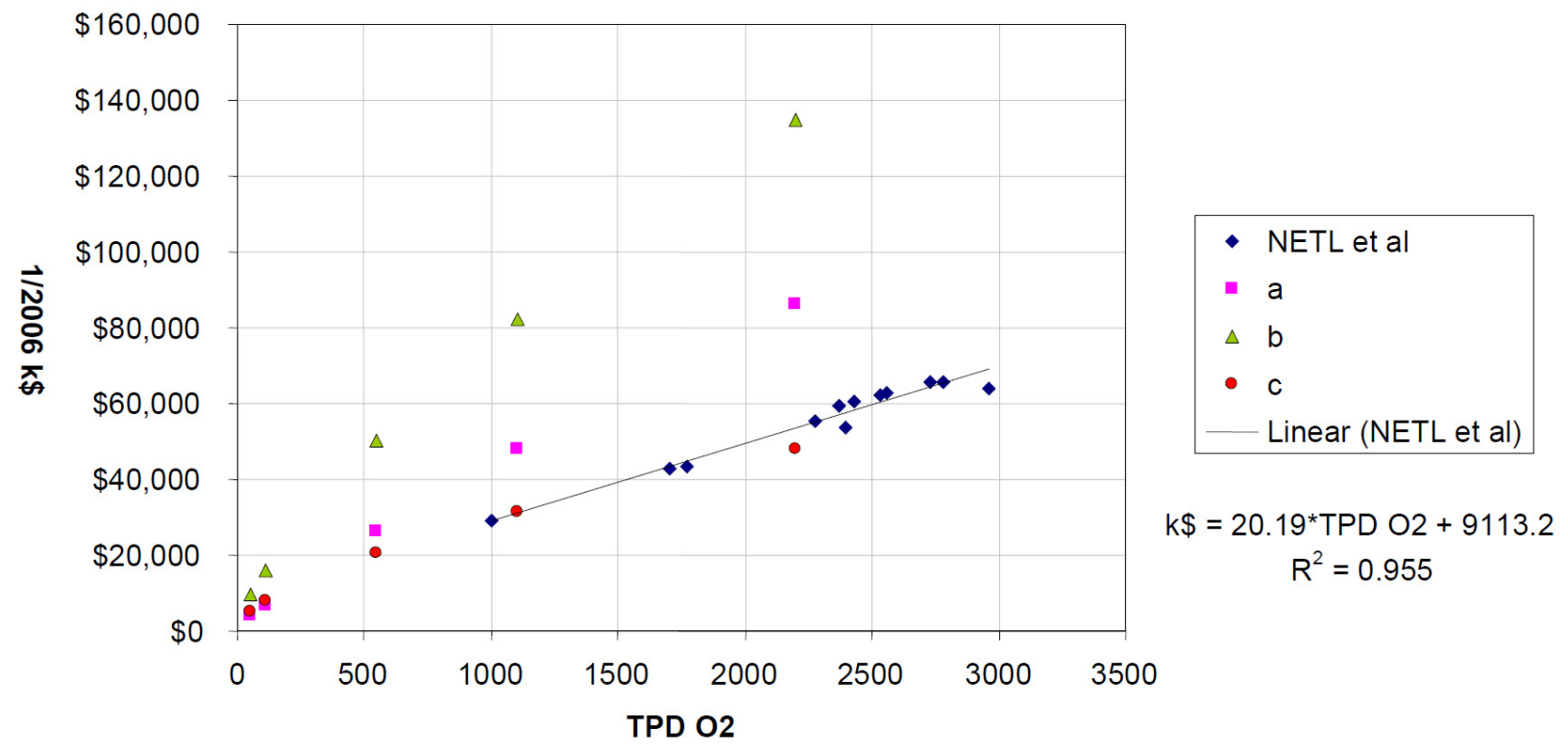

Figure A.1. Installed Costs for Cryogenic Air Separation Units (ASU) 
Tables A.1, A.2, and A.3 provide the equipment cost estimation and source details. The cost spreadsheet layout and much of the capital costs were derived from Spath et al. (2005) and Hammelink et al. (2001). The tables contain a list of specific capital costs and the date of the cost. These data are used to provide new capital costs for each case considered in this report as explained in Section 3.5. Table A.1 provides a key to the column headings for Tables A.2 (Indirectly-Heated Gasifier System Base Case) and A.3 Directly-Heated Gasifier System Base Case.

Table A.1. Description of Column Headings for Tables A.2 and A.3

\begin{tabular}{|c|c|c|}
\hline $\begin{array}{l}\text { Column } \\
\text { Number }\end{array}$ & Column Heading & Description \\
\hline 1 & & Processing area number (e.g., A200 is “feedprep") \\
\hline 2 & CC5 Equipment \# & $\begin{array}{l}\text { Equipment number from CHEMCAD flow sheet (See Appendix C). } \\
\text { Note A letter prefix to number indicates type of equipment } \\
\text { ( } \mathrm{E}=\text { heat exchanger, } \mathrm{P}=\text { pump, } \mathrm{T}=\text { tank or column, } \mathrm{V}=\text { vessel, } \\
\mathrm{R}=\text { reactor, } \mathrm{C}=\text { compressor, } \mathrm{H}=\text { hot oil system, } \mathrm{B}=\text { Boiler). NS } \\
\text { indicates equipment not shown individually on flow diagrams but } \\
\text { part of a group of equipment costed together. Multiple numbers } \\
\text { indicates a single piece of equipment shown as multiple pieces in } \\
\text { flow sheet (e.g., multiple stages of a compressor. NA means not } \\
\text { applicable. }\end{array}$ \\
\hline 3 & \# Reqd & Required number of equipment pieces \\
\hline 4 & \# Spares & Required number of spare equipment pieces \\
\hline 5 & Equipment Name & Equipment description \\
\hline 6 & Scaling or Stream Factor & $\begin{array}{l}\text { Basis for recalculating equipment costs from a base cost. Duty }= \\
\text { heat produced or required, Sxxx = refers to a stream number } \\
\text { (preceded by the S) that is labeled on the flow diagrams (e.g., S320 } \\
\text { means stream 320). See Appendix C for flow stream numbers. }\end{array}$ \\
\hline 7 & Original Stream Flow & $\begin{array}{l}\text { Original stream flow or metric (e.g., heat duty) value associated } \\
\text { with the base cost }\end{array}$ \\
\hline 8 & New Stream Flow & $\begin{array}{l}\text { New stream flow or metric value associated with the case being } \\
\text { costed }\end{array}$ \\
\hline 9 & Stream Flow Units & Units for the scaling metric value (MW, lb/hr, etc.) \\
\hline 10 & Size Ratio & Ratio of original scaling metric to new scaling metric \\
\hline 11 & Original Equipment Cost & Capital cost from the source for the specified equipment \\
\hline 12 & Base Year & Year that the capital cost in column 11 was estimated \\
\hline 13 & Installed (i) or Bare (b) & $\begin{array}{l}\text { Indicates whether the capital cost is an installed cost (i) or bare } \\
\text { equipment cost (b) }\end{array}$ \\
\hline 14 & Scaling Exp & $\begin{array}{l}\text { Exponent used to scale the capital cost from the original capacity to } \\
\text { the capacity in the case being costed }\end{array}$ \\
\hline 15 & Install Factor & $\begin{array}{l}\text { Factor that is multiplied by the bare equipment cost to get the } \\
\text { installed cost OR factor that is divided into the installed cost to get a } \\
\text { bare equipment cost }\end{array}$ \\
\hline 16 & Installed Cost $2007 \$$ & $\begin{array}{l}\text { Installed costs escalated from the original cost year (column 12) to } \\
1^{\text {st }} \mathrm{Q} 2007 \text { using the CE indices }\end{array}$ \\
\hline 17 & Bare Equipment Cost $2007 \$$ & $\begin{array}{l}\text { Bare equipment costs escalated from the original cost year } \\
\text { (column 12) to } 1^{\text {st }} \mathrm{Q} 2007 \text { using the CE indices }\end{array}$ \\
\hline 18 & Equip Cost Source & Source for equipment costs. See following discussion for keys. \\
\hline
\end{tabular}


The key to the entries in the "equip cost source" column in Table A.1 for the indirectly heated gasifier system equipment is:

1. Spath et al. 2005

2. ICARUS based on CC5 Base Case flow sheet

3. Phillips et al. 2007

4. Wang 2003

5. Hamelinck and Faaij 2002.

The key to the entries in the "equip cost source" column in Table A.2 for the directly heated gasifier system equipment is:

1. Spath et al. 2005

2. Phillips et al. 2007

3. ICARUS based on CC5 Base Case flow sheet

4. PEP 2003 Yearbook (referenced as Wang 2003)

5. Hamelinck and Faaij 2002

6. Various sources, see the references for air separation unit Figure A.1. 
Table A.2. Economic Cost Details for Indirectly-Heated Gasifier System Base Case

\begin{tabular}{|c|c|c|c|c|c|c|c|c|c|c|c|c|c|c|c|c|}
\hline Equip\# & \# Reqd & \# Spares & Equipment Name & $\begin{array}{c}\text { Scaling } \\
\text { Stream or } \\
\text { factor } \\
\end{array}$ & $\begin{array}{c}\text { Original } \\
\text { Stream Flow } \\
\end{array}$ & $\begin{array}{c}\text { New Stream } \\
\text { Flow }\end{array}$ & $\begin{array}{c}\text { stream flow } \\
\text { units }\end{array}$ & $\begin{array}{r}\text { Size } \\
\text { Ratio } \\
\end{array}$ & $\begin{array}{c}\text { Original } \\
\text { Equip Cost }\end{array}$ & Base Year & $\begin{array}{l}\text { Installed (i) } \\
\text { or bare (b) }\end{array}$ & $\begin{array}{c}\text { Scaling } \\
\text { Exp } \\
\end{array}$ & $\begin{array}{l}\text { Install } \\
\text { Factor }\end{array}$ & $\begin{array}{l}\text { Installed } \\
\text { Cost in } \\
2007 \$ \\
\end{array}$ & $\begin{array}{c}\text { Bare Equip } \\
\text { cost in } \\
2007 \$ \\
\end{array}$ & $\begin{array}{c}\text { Equip Cost } \\
\text { Source } \\
\end{array}$ \\
\hline \multicolumn{17}{|c|}{ A200 } \\
\hline E251 & 1 & 0 & Flue Gas Cooler / Steam Generator \#3 & Duty & $1,369,986$ & $7,363,000$ & $\mathrm{BTU} / \mathrm{h}$ & 5.37 & $\$ 26,143$ & 2002 & b & 0.65 & 2.47 & 249,970 & $\$ 101,202$ & 1 \\
\hline NS & NA & NA & Feed Handling and Drying System & S200 & 367,437 & 367,437 & $\mathrm{lb} / \mathrm{h}$ & 1.00 & $\$ 3,813,728$ & 2002 & $\mathrm{~b}$ & 0.65 & 2.47 & $24,445,073$ & $\$ 9,896,791$ & 1 \\
\hline 200 & 2 & 0 & Rotary Biomass Dryer & & & & & & Included in $\mathrm{f}$ & ed handling \& & drying cost & & & & & \\
\hline 203 & 1 & 0 & Heat exchanger & & & & & & Included in $\mathrm{f}$ & ed handling \& & drying cost & & & & & \\
\hline NS & 4 & 0 & Hopper Feeder & & & & & & Included in $\mathrm{f}$ & ed handling \& & drying cost & & & & & \\
\hline NS & 2 & 0 & Screener Feeder Conveyor & & & & & & Included in $\mathrm{f}$ & ed handling \& & drying cost & & & & & \\
\hline NS & 2 & 0 & Radial Stacker Conveyor & & & & & & Included in $\mathrm{f}$ & ed handling \& & $\begin{array}{l}\text { drying cost } \\
\text { drats }\end{array}$ & & & & & \\
\hline NS & 2 & 0 & Dryer Feed Screw Conveyor & & & & & & Included in $\mathrm{f}$ & ed handling \& & drying cost & & & & & \\
\hline NS & 2 & 0 & Gasifier Feed Screw Conveyor & & & & & & Included in $\mathrm{f}$ & ed handling \& & drying cost & & & & & \\
\hline NS & 2 & 0 & Flue Gas Blower & & & & & & Included in $\mathrm{f}$ & ed handling \& & drying cost & & & & & \\
\hline NS & 4 & 0 & Hydraulic Truck Dump with Scale & & & & & & Included in $\mathrm{f}$ & ed handling \& & drying cost & & & & & \\
\hline NS & 2 & 0 & Hammermill & & & & & & Included in $\mathrm{f}$ & ed handling \& & drying cost & & & & & 1 \\
\hline NS & 3 & 0 & Front End Loaders & & & & & & Included in $\mathrm{f}$ & ed handling \& & drying cost & & & & & \\
\hline NS & 2 & 0 & Magnetic Head Pulley & & & & & & Included in $\mathrm{f}$ & ed handling \& & drying cost & & & & & \\
\hline NS & 2 & 0 & Screener & & & & & & Included in $\mathrm{f}$ & ed handling \& & drying cost & & & & & \\
\hline NS & 2 & 0 & Dryer Air Cyclone & & & & & & Included in $\mathrm{f}$ & ed handling \& & drying cost & & & & & \\
\hline NS & 2 & 0 & Dryer Air Baghouse Filter & & & & & & Included in $\mathrm{f}$ & ed handling \& & drying cost & & & & & \\
\hline NS & 4 & 0 & Dump Hopper & & & & & & Included in $\mathrm{f}$ & ed handling \& & drying cost & & & & & \\
\hline NS & 1 & 0 & Hammermill Surge Bin & & & & & & Included in $\mathrm{f}$ & ed handling \& & drying cost & & & & & \\
\hline NS & 2 & 0 & Dryer Feed Bin & & & & & & Included in $\mathrm{f}$ & ed handling \& & drying cost & & & & & \\
\hline NS & 2 & 0 & Dried Biomass Hopper & & & & & & Included in $\mathrm{f}$ & ed handling \& & drying cost & & & & & \\
\hline
\end{tabular}

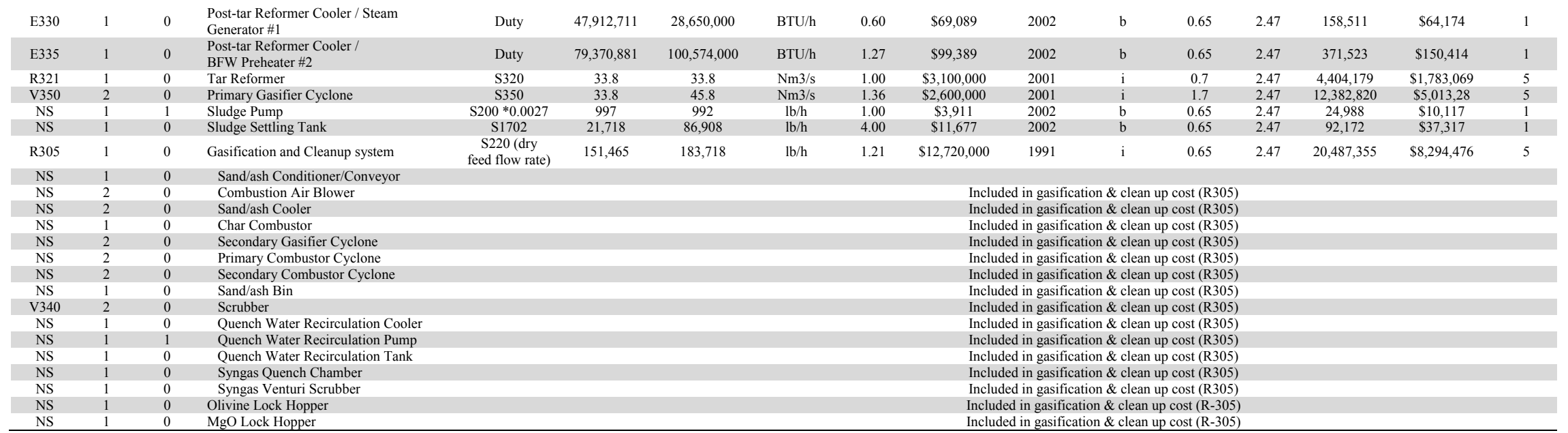


Table A.2. (contd)

\begin{tabular}{|c|c|c|c|c|c|c|c|c|c|c|c|c|c|c|c|c|}
\hline Equip \# & \# Reqd & \# Spares & Equipment Name & $\begin{array}{l}\text { Scaling } \\
\text { Stream or } \\
\text { factor } \\
\end{array}$ & $\begin{array}{c}\text { Original } \\
\text { Stream Flow } \\
\end{array}$ & $\begin{array}{l}\text { New Stream } \\
\text { Flow }\end{array}$ & $\begin{array}{c}\begin{array}{c}\text { stream flow } \\
\text { units }\end{array} \\
\end{array}$ & $\begin{array}{r}\text { Size } \\
\text { Ratio }\end{array}$ & $\begin{array}{c}\text { Original } \\
\text { Equip Cost }\end{array}$ & Base Year & $\begin{array}{l}\text { Installed (i) } \\
\text { or bare (b) }\end{array}$ & $\begin{array}{c}\text { Scaling } \\
\text { Exp }\end{array}$ & $\begin{array}{l}\text { Install } \\
\text { Factor }\end{array}$ & $\begin{array}{l}\text { Installed } \\
\text { Cost in } \\
2007 \$ \\
\end{array}$ & $\begin{array}{c}\text { Bare Equip } \\
\text { cost in } \\
2007 \$ \\
\end{array}$ & $\begin{array}{c}\text { Equip Cost } \\
\text { Source }\end{array}$ \\
\hline $\begin{array}{l}\text { C410, } \\
\text { C412, } \\
\text { C414, } \\
\text { C416, } \\
\text { C418 } \\
\text { C420 }\end{array}$ & 1 & 0 & Syngas Compressor & S345 & 236,858 & 193,345 & A400 & 0.82 & $\$ 10,030,400$ & 2002 & $\mathrm{~b}$ & 0.65 & 2.47 & $22,899,410$ & $\$ 9,271,016$ & 1 \\
\hline $\begin{array}{l}\text { E411, } \\
\text { E412, } \\
\text { E415, } \\
\text { E17, E19 }\end{array}$ & 5 & 0 & Syngas Compressor Intercoolers & Duty & & \multicolumn{11}{|c|}{ Included in the syngas compressor cost (C-410, etc.) } \\
\hline NS & 4 & 0 & $\begin{array}{l}\text { Syngas Compressor Interstage } \\
\text { Knock-outs }\end{array}$ & Duty & & \multicolumn{11}{|c|}{ Included in the syngas compressor cost (C-410, etc.) } \\
\hline NS & 1 & 0 & Pre-compressor Knock-out & S345 & 220,009 & 193,345 & $\mathrm{lb} / \mathrm{h}$ & 0.88 & $\$ 157,277$ & 2002 & & 0.65 & 2.47 & 463,455 & $\$ 187,633$ & 1 \\
\hline $\mathrm{E} 420$ & 1 & 0 & Water-cooled Aftercooler & Duty & $2,938,799$ & $2,734,000$ & $\mathrm{mmbtu} / \mathrm{h}$ & 0.93 & $\$ 20,889$ & 2002 & $\mathrm{~b}$ & 0.65 & 2.47 & 63,876 & $\$ 25,861$ & 1 \\
\hline V429 & 1 & 0 & Post-compressor Knock-out & S426 & 179,394 & 164,720 & $\mathrm{lb} / \mathrm{h}$ & 0.92 & $\$ 40,244$ & 2002 & $\mathrm{~b}$ & 0.65 & 2.47 & 122,018 & $\$ 49,400$ & 1 \\
\hline E431 & 1 & 0 & LO-CAT Preheater & Duty & 770,434 & 650,000 & BTU/h & 0.84 & $\$ 4,743$ & 2002 & $\mathrm{~b}$ & 0.65 & 2.47 & 13,611 & $\$ 5,510$ & 1 \\
\hline V430 & 1 & 0 & LO-CAT Oxidizer Vessel & $\mathrm{S} 434 * 13.5$ & 517 & 513 & $\mathrm{lb} / \mathrm{h}$ & 0.99 & $\$ 1,000,000$ & 2002 & & 0.65 & 2.47 & $3,188,742$ & $\$ 1,290,989$ & 1 \\
\hline $\begin{array}{l}\text { NS } \\
\text { NS }\end{array}$ & 1 & 0 & $\begin{array}{l}\text { LO-CAT Absorbent Solution Cooler } \\
\text { Dat }\end{array}$ & & & & & & Included in LO & CAT oxidizer & vessel cost $(\mathrm{V}$ & 430) & & & & \\
\hline NS & 1 & 0 & LO-CAT Feed Air Blower & & & & & & Included in LO & CAT oxidizer & vessel cost $(\mathrm{V}$ & 430) & & & & \\
\hline $\begin{array}{l}\text { NS } \\
\text { NS }\end{array}$ & 1 & 0 & LO-CAT Venturi Precontactor & & & & & & Included in LO & CAT oxidizer & vessel cost $(\mathrm{V}$ & 430) & & & & \\
\hline NS & 1 & 0 & LO-CAT Liquid-filled Absorber & & & & & & Included in LO & CAT oxidizer & vessel cost $(\mathrm{V}$ & & & & & \\
\hline NS & 1 & 1 & $\begin{array}{l}\text { LO-CAT Absorbent Solution Circulating } \\
\text { Pump }\end{array}$ & & & \multicolumn{11}{|c|}{ Included in LO-CAT oxidizer vessel cost (V-430) } \\
\hline E432 & 1 & 0 & ZnO Bed Preheater & Duty & $47,209,942$ & $39,740,000$ & BTU/h & 0.84 & $\$ 71,389$ & 2002 & $\mathrm{~b}$ & 0.65 & 2.47 & 204,559 & $\$ 82,818$ & 1 \\
\hline V435 & 2 & 0 & ZnO Sulfur Removal Beds & S433 & 179,237 & 157,671 & $\mathrm{lb} / \mathrm{h}$ & 0.88 & $\$ 37,003$ & 2002 & $\mathrm{~b}$ & 0.65 & 2.47 & 218,217 & $\$ 88,347$ & 1 \\
\hline C452 & 1 & 0 & $\mathrm{CO} 2$ Compressor & S454 & 100,000 & 13,203 & $\mathrm{lb} / \mathrm{h}$ & 0.13 & $1,237,700$ & 1Q 2005 & $\mathrm{i}$ & 0.65 & 2.47 & 364,610 & $\$ 147,615$ & 2 \\
\hline C497 & 1 & 0 & Reformer Flue Gas Blower & S498 & 534,677 & 181,568 & $\mathrm{lb} / \mathrm{h}$ & 0.34 & $\$ 54,250$ & 2002 & b & 0.65 & 2.47 & 86,164 & $\$ 34,884$ & 1 \\
\hline E494 & 1 & 0 & Reformer Feed Preheater & Duty & $47,628,665$ & $20,112,400$ & BTU/h & 0.42 & $\$ 277,489$ & 2002 & b & 0.65 & 2.47 & 507,802 & $\$ 205,588$ & 1 \\
\hline E444 & 1 & 0 & Reformed Syngas Cooler & Duty & $155,010,823$ & $103,972,000$ & BTU/h & 0.67 & $\$ 347,989$ & 2002 & b & 0.65 & 2.47 & 860,276 & $\$ 348,290$ & 1 \\
\hline E443 & 1 & 0 & Reformed Syngas Cooler & Duty & $13,974,577$ & $13,740,800$ & BTU/h & 0.98 & $\$ 92,889$ & 2002 & b & 0.65 & 2.47 & 294,452 & $\$ 119,211$ & 1 \\
\hline E442 & 1 & 0 & Reformed Syngas Cooler & Duty & $13,974,577$ & $50,338,700$ & BTU/h & 3.60 & $\$ 92,889$ & 2002 & b & 0.65 & 2.47 & 684,766 & $\$ 277,233$ & 1 \\
\hline E495 & 1 & 0 & $\begin{array}{l}\text { Reformer Flue Gas Cooler/Steam } \\
\text { Superheater } \# 2\end{array}$ & Duty & $94,212,763$ & $22,305,900$ & BTU/h & 0.24 & $\$ 196,589$ & 2002 & $\mathrm{~b}$ & 0.65 & 2.47 & 246,986 & $\$ 99,994$ & 1 \\
\hline NS & 1 & 0 & Air-cooled Precooler & Duty & $149,281,592$ & $22,974,500$ & BTU/h & 0.15 & $\$ 388,064$ & 2002 & $\mathrm{~b}$ & 0.65 & 2.47 & 368,486 & $\$ 149,185$ & 1 \\
\hline E449 & 1 & 0 & Water-cooled Precooler & Duty & $8,414,338$ & $5,636,740$ & $\mathrm{BTU} / \mathrm{h}$ & 0.67 & $\$ 35,689$ & 2002 & b & & 2.47 & 88,156 & $\$ 35,691$ & 1 \\
\hline C490 & 1 & 0 & Reformer Combustion Air Blower & S490 & 304,578 & 170,009 & $\mathrm{lb} / \mathrm{h}$ & 0.56 & $\$ 35,020$ & 2002 & b & 0.65 & 2.47 & 76,830 & $\$ 31,105$ & 1 \\
\hline $\mathrm{R} 440$ & 1 & 0 & Steam Reformer & DUTY & $158,705,747$ & $100,834,000$ & BTU/h & 0.64 & $\$ 4,965,833$ & 2002 & b & 0.65 & 2.47 & $11,851,228$ & $\$ 4,798,068$ & 1 \\
\hline V449 & 1 & 0 & Knock-out \#1 & S449 & 354,424 & 219,120 & $\mathrm{lb} / \mathrm{h}$ & 0.62 & $\$ 129,979$ & 2002 & $\mathrm{~b}$ & 0.65 & 2.47 & 304,746 & $\$ 123,379$ & 1 \\
\hline V450 & 1 & 0 & Amine System (ISBL installed) & S453 & 100,203 & 60,065 & $\mathrm{lb} / \mathrm{h} \mathrm{CO} 2$ & 0.60 & $\$ 23,000,000$ & 2003 & $\mathrm{i}$ & 0.73 & 2.47 & $20,212,675$ & $\$ 8,183,269$ & 4 \\
\hline $\begin{array}{l}\text { C470, } \\
\text { C471, } \\
\text { C472, } \\
\text { C473, } \\
\text { C474 }\end{array}$ & 1 & 0 & Synth. Feed Compressor w coolers \& KO's & & 161,785 & 122,595 & $\mathrm{lb} / \mathrm{h}$ & 0.76 & $\$ 3,896,834$ & 2002 & b & 0.65 & 2.47 & $8,476,493$ & $\$ 3,431,779$ & 1 \\
\hline NS & 1 & 0 & Knock-out \#2 & S451 & 242,691 & 122,595 & $\mathrm{lb} / \mathrm{h}$ & 0.51 & $\$ 55,291$ & 2002 & & 0.65 & 2.47 & 113,681 & $\$ 46,025$ & 1 \\
\hline \multicolumn{17}{|c|}{ A500 and A600 } \\
\hline R500 & 1 & 0 & Mixed Alcohol Synthesis Reactor & $\mathrm{S} 512$ & $1,151,936$ & $1,151,936$ & $\mathrm{lb} / \mathrm{h}$ & 1.00 & $\$ 12,674,694$ & 1Q 2005 & $\mathrm{~b}$ & 0.65 & 2.47 & $34,388,238$ & $\$ 13,922,363$ & 2 \\
\hline E505 & 1 & 0 & Feed/Product Exchanger & AREA & 20,548 & 20,548 & $\mathrm{ft} 2$ & 1.00 & $2,290,000$ & 1Q 2007 & $\mathrm{~b}$ & 0.65 & 2.47 & $5,656,300$ & $\$ 2,290,000$ & 2 \\
\hline E506 & 1 & 0 & Product Air Cooler & Duty & 104 & 102 & $\mathrm{mmbtu} / \mathrm{h}$ & 0.98 & 419,400 & 1Q 2005 & b & 0.65 & 2.47 & $1,120,445$ & $\$ 453,622$ & 2 \\
\hline E508 & 1 & 0 & Product Trim Cooler & AREA & 8,848 & 8,848 & $\mathrm{ft} 2$ & 1.00 & 571,300 & 1Q 2007 & b & 0.65 & 2.47 & $1,411,111$ & $\$ 571,300$ & 2 \\
\hline V511 & 1 & 0 & High Pressure V-L Separator & S521 & $1,151,934$ & $1,151,934$ & $\mathrm{lb} / \mathrm{h}$ & 1.00 & 254,800 & 1Q 2000 & b & 0.65 & 2.47 & 629,347 & $\$ 254,797$ & 2 \\
\hline V513 & 1 & 0 & Low Pressure V-L Separator & S525 & 78,114 & 63,509 & $\mathrm{lb} / \mathrm{h}$ & 0.81 & 19,300 & 1Q 2005 & b & 0.65 & 2.47 & 45,772 & $\$ 18,531$ & 2 \\
\hline A-550 & 1 & 0 & HP Amine System (ISBL installed) & S553 & 100,203 & 45,927 & $\mathrm{lb} / \mathrm{h} \mathrm{CO} 2$ & 0.46 & $\$ 23,000,000$ & 2003 & $\mathrm{i}$ & 0.73 & 2.47 & $16,616,510$ & $\$ 6,727,332$ & 4 \\
\hline $\mathrm{C}-551$ & 1 & 0 & Recycle Compresser & $\mathrm{S} 555$ & $1,020,705$ & $1,020,730$ & $\mathrm{lb} / \mathrm{h}$ & 1.00 & $1,002,900$ & 1Q 2005 & $\mathrm{i}$ & 0.65 & 2.47 & $1,101,641$ & $\$ 446,008$ & 2 \\
\hline E-560 & 1 & 0 & Recycle Methanol Vaporizer & AREA & 175 & 122 & $\mathrm{ft} 2$ & 0.70 & 19,700 & 1Q 2005 & b & 0.65 & 2.47 & 42,276 & $\$ 17,116$ & 2 \\
\hline P-612 & 1 & 0 & Recycle Methanol Pump & S612 & 12,414 & 8,608 & $\mathrm{lb} / \mathrm{h}$ & 0.69 & 0 & 1Q 2005 & b & 0.65 & 2.47 & 0 & $\$ 0$ & 2 \\
\hline MS620 & 1 & 0 & Molecular Sieve Alcohol Dryer & S621 & 45,175 & 59,844 & $\mathrm{lb} / \mathrm{h}$ & 1.32 & 904,694 & 1998 & b & 0.7 & 2.47 & $3,585,487$ & $\$ 1,451,614$ & 3 \\
\hline $\mathrm{T}-601$ & 1 & 0 & Light Ends Column & S528 & 73,801 & 60,699 & $\mathrm{lb} / \mathrm{h}$ & 0.82 & 271,800 & 1Q 2005 & b & 0.65 & 2.47 & 649,456 & $\$ 262,937$ & 2 \\
\hline T-610 & 1 & 0 & Methanol Column & S623 & 64,269 & 52,045 & $\mathrm{lb} / \mathrm{h}$ & 0.81 & $1,604,500$ & 1Q 2005 & b & 0.65 & 2.47 & $3,795,400$ & $\$ 1,536,599$ & 2 \\
\hline
\end{tabular}


Table A.2. (contd)

\begin{tabular}{|c|c|c|c|c|c|c|c|c|c|c|c|c|c|c|c|c|}
\hline Equip \# & \# Reqd & \# Spares & Equipment Name & $\begin{array}{l}\text { Scaling } \\
\text { Stream or } \\
\text { factor }\end{array}$ & $\begin{array}{c}\text { Original } \\
\text { Stream Flow }\end{array}$ & $\begin{array}{l}\text { New Stream } \\
\text { Flow }\end{array}$ & $\begin{array}{c}\text { stream flow } \\
\text { units }\end{array}$ & $\begin{array}{r}\text { Size } \\
\text { Ratio }\end{array}$ & $\begin{array}{l}\text { Original } \\
\text { Equip Cost }\end{array}$ & Base Year & $\begin{array}{l}\begin{array}{l}\text { Installed (i) } \\
\text { or bare (b) }\end{array} \\
\end{array}$ & $\begin{array}{c}\text { Scaling } \\
\text { Exp }\end{array}$ & $\begin{array}{l}\text { Install } \\
\text { Factor } \\
\end{array}$ & $\begin{array}{l}\text { Installed } \\
\text { Cost in } \\
2007 \$ \\
\end{array}$ & $\begin{array}{l}\text { Bare Equip } \\
\text { cost in } \\
2007 \$ \\
\end{array}$ & $\begin{array}{c}\text { Equip Cost } \\
\text { Source }\end{array}$ \\
\hline T- 630 & 1 & 0 & Ethanol Column & $\mathrm{S} 631$ & 37,727 & 31,717 & $\mathrm{lb} / \mathrm{h}$ & 0.84 & 410,700 & 1Q 2005 & $\mathrm{~b}$ & 0.65 & 2.47 & 995,435 & $\$ 403,010$ & 2 \\
\hline $\mathrm{T}-640$ & 1 & 0 & Propanol Column & S641 & 7,748 & 6,518 & $\mathrm{lb} / \mathrm{h}$ & 0.84 & 183,400 & 1Q 2005 & $\mathrm{~b}$ & 0.65 & 2.47 & 444,706 & $\$ 180,043$ & 2 \\
\hline $\mathrm{T}-650$ & 1 & 0 & Butanol Column & S651 & 3,329 & 2,825 & $\mathrm{lb} / \mathrm{h}$ & 0.85 & 261,000 & 1Q 2005 & b & 0.65 & 2.47 & 636,460 & $\$ 257,676$ & 2 \\
\hline E601 & 1 & 0 & Light Ends Column Condenser & DUTY & 8.46 & 8.46 & $\mathrm{mmbtu} / \mathrm{h}$ & 1.00 & $\$ 24,800$ & 1Q 2005 & b & 0.65 & 2.47 & 67,286 & $\$ 27,241$ & 2 \\
\hline E602 & 1 & 0 & Light Ends Column Reboiler & DUTY & 12.96 & 12.96 & $\mathrm{mmbtu} / \mathrm{h}$ & 1.00 & 104,900 & 1Q 2005 & b & 0.65 & 2.47 & 284,609 & $\$ 115,226$ & 2 \\
\hline E611 & 1 & 0 & Methanol Column Condenser & DUTY & 96.32 & 96.17 & $\mathrm{mmbtu} / \mathrm{h}$ & 1.00 & 54,100 & 1Q 2005 & b & 0.65 & 2.47 & 146,632 & $\$ 59,365$ & 2 \\
\hline E612 & 1 & 0 & Methanol Column Reboiler & DUTY & 96.42 & 96.27 & $\mathrm{mmbtu} / \mathrm{h}$ & 1.00 & 22,300 & 1Q2005 & b & 0.65 & 2.47 & 60,442 & $\$ 24,470$ & 2 \\
\hline E631 & 1 & 0 & Ethanol Column Condenser & DUTY & 33.04 & 33.04 & $\mathrm{mmbtu} / \mathrm{h}$ & 1.00 & 5,800 & 1Q 2005 & b & 0.65 & 2.47 & 15,736 & $\$ 6,371$ & 2 \\
\hline E632 & 1 & 0 & Ethanol Column Reboiler & DUTY & 32.82 & 32.82 & $\mathrm{mmbtu} / \mathrm{h}$ & 1.00 & 52,500 & 1Q 2005 & b & 0.65 & 2.47 & 142,440 & $\$ 57,668$ & 2 \\
\hline E641 & 1 & 0 & Propanol Column Condenser & DUTY & 5.76 & 5.76 & $\mathrm{mmbtu} / \mathrm{h}$ & 1.00 & 183,500 & 1Q 2005 & $\mathrm{~b}$ & 0.65 & 2.47 & 497,861 & $\$ 201,563$ & 2 \\
\hline $\mathrm{E} 642$ & 1 & 0 & Propanol Column Reboiler & DUTY & 5.76 & 5.76 & $\mathrm{mmbtu} / \mathrm{h}$ & 1.00 & 123,300 & 1Q 2005 & b & 0.65 & 2.47 & 334,530 & $\$ 135,437$ & 2 \\
\hline E651 & 1 & 0 & Butanol Column Condenser & DUTY & 2.11 & 2.11 & $\mathrm{mmbtu} / \mathrm{h}$ & 1.00 & 39,500 & 1Q 2005 & $\mathrm{~b}$ & 0.65 & 2.47 & 107,169 & $\$ 43,388$ & 2 \\
\hline \multirow{3}{*}{$\begin{array}{l}\mathrm{E} 652 \\
\mathrm{H}-680\end{array}$} & 1 & 0 & Butanol Column Reboiler & DUTY & 2.12 & 2.12 & $\mathrm{mmbtu} / \mathrm{h}$ & 1.00 & 29,300 & 1Q2005 & $\mathrm{b}$ & 0.65 & 2.47 & 79,495 & $\$ 32,184$ & 2 \\
\hline & 1 & 0 & Hot Oil System for T-640 \& T-650 & DUTY & 8.00 & 7.88 & $\mathrm{mmbtu} / \mathrm{h}$ & 0.99 & 214,000 & 1Q2005 & $\mathrm{b}$ & 1.65 & 2.47 & 566,312 & $\$ 229,276$ & 2 \\
\hline & & & $\begin{array}{l}\text { Misc equipment contingency (reflux } \\
\text { drums, pumps, etc) }\end{array}$ & $\begin{array}{l}\text { Estimated } \\
\text { from } \\
\text { distillation } \\
\text { costs }\end{array}$ & $5 \%$ & & & & 136,570 & 1Q 2005 & $\mathrm{~b}$ & 0.65 & 2.47 & 370,534 & $\$ 150,014$ & 2 \\
\hline
\end{tabular}

\begin{tabular}{|c|c|c|c|c|c|c|c|c|c|c|c|c|c|c|c|c|}
\hline \multirow{6}{*}{$\begin{array}{c}\mathrm{NS} \\
\mathrm{NS} \\
\text { EX730,7 } \\
40,750 \\
\mathrm{NS}\end{array}$} & 1 & 0 & $\begin{array}{l}\text { Blowdown Cooler / Deaerator Water } \\
\text { Preheater }\end{array}$ & S770 & $2,877,029$ & 89,545 & $\mathrm{lb} / \mathrm{h}$ & 0.03 & $\$ 3,043$ & 2002 & b & 0.6 & 2.47 & 1,153 & $\$ 467$ & 1 \\
\hline & 1 & 0 & Blowdown Water-cooled Cooler & $\mathrm{S} 711$ & 626,343 & 3,815 & $\mathrm{lb} / \mathrm{h}$ & 0.01 & $\$ 16,143$ & 2002 & $\mathrm{~b}$ & 0.44 & 2.47 & 5,199 & $\$ 2,105$ & 1 \\
\hline & 1 & 0 & Hot Process Water Softener System & S777-S770 & 349,266 & 218,422 & $\mathrm{lb} / \mathrm{h}$ & 0.63 & $\$ 1,031,023$ & 1999 & $\mathrm{~b}$ & 0.82 & 2.47 & $2,157,172$ & $\$ 873,349$ & 1 \\
\hline & 1 & 0 & Extraction Steam Turbine/Generator & S725 & 342,283 & 394,082 & $\mathrm{lb} / \mathrm{h}$ & 1.15 & $\$ 4,045,870$ & 2002 & $\mathrm{~b}$ & 0.71 & 2.47 & $13,588,341$ & $\$ 5,501,353$ & 1 \\
\hline & 1 & 0 & Steam Turbine Condenser & & & & & \multicolumn{9}{|c|}{ Included in the extraction steam turbine/generator cost } \\
\hline & 1 & 0 & Startup Boiler & $\begin{array}{l}\text { Calculated } \\
\text { from gasifier } \\
\text { size }\end{array}$ & 36,560 & 36,560 & $\mathrm{lb} / \mathrm{h}$ & 1.00 & $\$ 198,351$ & 2002 & $\mathrm{~b}$ & 0.6 & 2.47 & 602,749 & $\$ 244,028$ & 1 \\
\hline B715 & 1 & 0 & $\begin{array}{l}\text { Fuel Gas Steam Boiler (mult for higher } \\
\text { pressure) }\end{array}$ & $\begin{array}{c}\text { Scenario } \\
\text { dependent }\end{array}$ & 169,341 & 165,198 & $\mathrm{lb} / \mathrm{h}$ & 0.98 & $\$ 1,748,700$ & 1Q 2005 & $\mathrm{i}$ & 0.6 & 2.47 & $2,119,659$ & $\$ 858,161$ & 1 \\
\hline P782 & 1 & 1 & BFW HP pump & $\mathrm{S} 782$ & 255,292 & 397,894 & $\mathrm{lb} / \mathrm{h}$ & 1.56 & $\$ 7,015$ & 2002 & $\mathrm{~b}$ & 0.33 & 2.47 & 49,358 & $\$ 19,983$ & 1 \\
\hline P761 & 1 & 1 & Condensate Pump & S761 & 93,974 & 166,852 & $\mathrm{lb} / \mathrm{h}$ & 1.78 & $\$ 5,437$ & 2002 & b & 0.33 & 2.47 & 39,936 & $\$ 16,169$ & 1 \\
\hline NS & 1 & 1 & Deaerator Feed Pump & S777 & 349,266 & 307,967 & $\mathrm{lb} / \mathrm{h}$ & 0.88 & $\$ 8,679$ & 2002 & b & 0.33 & 2.47 & 50,602 & $\$ 20,487$ & 1 \\
\hline P780 & 1 & 1 & Boiler Feed Water Pump & S779 & 349,268 & 476,818 & $\mathrm{lb} / \mathrm{h}$ & 1.37 & $\$ 95,660$ & 2002 & b & 0.33 & 2.47 & 644,283 & $\$ 260,843$ & 1 \\
\hline NS & 1 & 0 & Condensate Collection Tank & S777 & 349,266 & 307,967 & $\mathrm{lb} / \mathrm{h}$ & 0.88 & $\$ 24,493$ & 2002 & $\mathrm{~b}$ & 0.6 & 2.47 & 69,016 & $\$ 27,942$ & 1 \\
\hline NS & 1 & 0 & Condensate Surge Drum & S777 & 349,268 & 307,967 & $\mathrm{lb} / \mathrm{h}$ & 0.88 & $\$ 28,572$ & 2002 & b & 0.6 & 2.47 & 80,510 & $\$ 32,595$ & 1 \\
\hline V705 & 1 & 0 & Deaerator & S777 & 349,266 & 307,967 & $\mathrm{lb} / \mathrm{h}$ & 0.88 & $\$ 130,721$ & 2002 & $\mathrm{~b}$ & 0.72 & 2.47 & 362,826 & $\$ 146,893$ & 1 \\
\hline V700 & 1 & 0 & Steam Drum & S704 & 349,268 & 232,690 & $\mathrm{lb} / \mathrm{h}$ & 0.67 & $\$ 9,200$ & 1997 & b & 0.72 & 2.47 & 21,332 & $\$ 8,637$ & 1 \\
\hline V703 & 1 & 0 & Blowdown Flash Drum & S711+S1974 & 6,985 & 3,815 & $\mathrm{lb} / \mathrm{h}$ & 0.55 & $\$ 14,977$ & 2002 & $\mathrm{~b}$ & 0.6 & 2.47 & 31,661 & $\$ 12,818$ & 1 \\
\hline & \multicolumn{16}{|c|}{900 (miscellaneous equipment) } \\
\hline NS & 2 & 1 & Plant Air Compressor & S200 & 367,437 & 367,437 & $\mathrm{lb} / \mathrm{h}$ & 1.00 & $\$ 32,376$ & 2002 & $\mathrm{~b}$ & 0.34 & 2.47 & 295,155 & $\$ 119,496$ & 1 \\
\hline NS & 1 & 0 & Cooling Tower System & calculated & $139,850,763$ & $40,921,343$ & $\mathrm{lb} / \mathrm{h}$ & 0.29 & $\$ 267,316$ & 2002 & $\mathrm{~b}$ & 0.78 & 2.47 & 311,479 & $\$ 126,105$ & 1 \\
\hline NS & 1 & 0 & Hydraulic Truck Dump with Scale & S200 & 367,437 & 367,437 & $\mathrm{lb} / \mathrm{h}$ & 1.00 & $\$ 80,000$ & 1998 & b & 0.6 & 2.47 & 246,595 & $\$ 99,836$ & 1 \\
\hline NS & 1 & 0 & Flue Gas Stack & $\begin{array}{l}\mathrm{S} 380+\mathrm{S} 498+\mathrm{S} \\
756\end{array}$ & $1,174,206$ & 881,559 & $\mathrm{lb} / \mathrm{h}$ & 0.75 & $\$ 51,581$ & 2002 & $\mathrm{~b}$ & 1 & 2.47 & 117,679 & $\$ 47,643$ & 1 \\
\hline NS & 1 & 1 & Cooling Water Pump & calculated & $6,088,320$ & $6,138,201$ & $\mathrm{lb} / \mathrm{h}$ & 1.01 & $\$ 158,540$ & 2002 & b & 0.33 & 2.47 & 966,140 & $\$ 391,150$ & 1 \\
\hline NS & 1 & 1 & Firewater Pump & S200 & 367,437 & 367,437 & $\mathrm{lb} / \mathrm{h}$ & 1.00 & $\$ 18,400$ & 1997 & b & 0.79 & 2.47 & 114,313 & $\$ 46,280$ & 1 \\
\hline NS & 1 & 1 & Diesel Pump & S200 & 367,437 & 367,437 & $\mathrm{lb} / \mathrm{h}$ & 1.00 & $\$ 6,100$ & 1997 & $\mathrm{~b}$ & 0.79 & 2.47 & 37,897 & $\$ 15,343$ & 1 \\
\hline NS & 1 & 1 & Ammonia Pump & S200 & 367,437 & 367,437 & $\mathrm{lb} / \mathrm{h}$ & 1.00 & $\$ 6,100$ & 1997 & b & 0.79 & 2.47 & 37,897 & $\$ 15,343$ & 1 \\
\hline NS & 1 & 0 & Hydrazine Pump & S200 & 367,437 & 367,437 & $\mathrm{lb} / \mathrm{h}$ & 1.00 & $\$ 5,500$ & 1997 & b & 0.79 & 2.47 & 17,085 & $\$ 6,917$ & 1 \\
\hline NS & 1 & 1 & Instrument Air Dryer & S200 & 367,437 & 367,437 & $\mathrm{lb} / \mathrm{h}$ & 1.00 & $\$ 8,349$ & 2002 & b & 0.6 & 2.47 & 50,742 & $\$ 20,543$ & 1 \\
\hline NS & 1 & 0 & Plant Air Receiver & S200 & 367,437 & 367,437 & $\mathrm{lb} / \mathrm{h}$ & 1.00 & $\$ 7,003$ & 2002 & b & 0.72 & 2.47 & 21,281 & $\$ 8,616$ & 1 \\
\hline NS & 1 & 0 & Firewater Storage Tank & S200 & 367,437 & 367,437 & $\mathrm{lb} / \mathrm{h}$ & 1.00 & $\$ 166,100$ & 1997 & b & 0.51 & 2.47 & 515,961 & $\$ 208,891$ & 1 \\
\hline NS & 1 & 0 & Diesel Storage Tank & S200 & 367,437 & 367,437 & $\mathrm{lb} / \mathrm{h}$ & 1.00 & $\$ 14,400$ & 1997 & $\mathrm{~b}$ & 0.51 & 2.47 & 44,731 & $\$ 18,110$ & 1 \\
\hline NS & 1 & 0 & Ammonia Storage Tank & S200 & 367,437 & 367,437 & $\mathrm{lb} / \mathrm{h}$ & 1.00 & $\$ 287,300$ & 1997 & b & 0.72 & 2.47 & 892,447 & $\$ 361,315$ & 1 \\
\hline NS & 1 & 0 & Hydrazine Storage Tank & S200 & 367,437 & 367,437 & $\mathrm{lb} / \mathrm{h}$ & 1.00 & $\$ 12,400$ & 1997 & $\mathrm{~b}$ & 0.93 & 2.47 & 38,518 & $\$ 15,595$ & 1 \\
\hline
\end{tabular}


Table A.3. Economic Cost Details for Directly-Heated Gasifier System Base Case

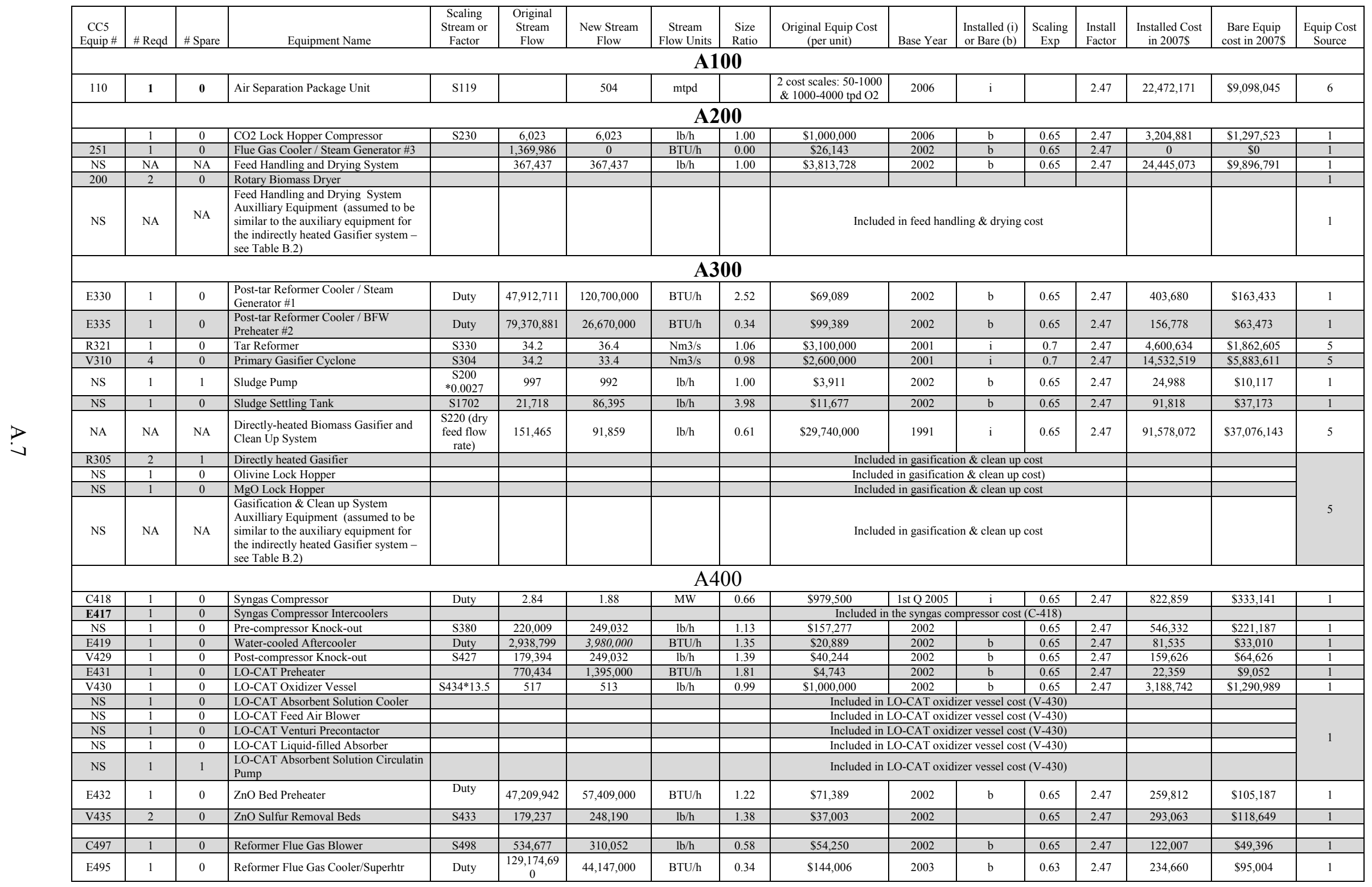


Table A.3. (contd)

\begin{tabular}{|c|c|c|c|c|c|c|c|c|c|c|c|c|c|c|c|c|}
\hline $\begin{array}{c}\text { CC5 } \\
\text { Equip\# }\end{array}$ & \# Reqd & \# Spare & Equipment Name & $\begin{array}{c}\text { Scaling } \\
\text { Stream or } \\
\text { Factor } \\
\end{array}$ & $\begin{array}{c}\text { Original } \\
\text { Stream } \\
\text { Flow } \\
4628\end{array}$ & $\begin{array}{c}\text { New Stream } \\
\text { Flow }\end{array}$ & $\begin{array}{c}\text { Stream } \\
\text { Flow Units }\end{array}$ & $\begin{array}{r}\text { Size } \\
\text { Ratio } \\
078\end{array}$ & $\begin{array}{c}\text { Original Equip Cost } \\
\text { (per unit) }\end{array}$ & Base Year & $\begin{array}{c}\begin{array}{c}\text { Installed (i) } \\
\text { or Bare (b) }\end{array} \\
\mathrm{b}\end{array}$ & \begin{tabular}{|l}
$\begin{array}{c}\text { Scaling } \\
\text { Exp }\end{array}$ \\
0.65
\end{tabular} & $\begin{array}{l}\text { Install } \\
\text { Factor } \\
2.47\end{array}$ & $\begin{array}{c}\begin{array}{c}\text { Installed Cost } \\
\text { in } 2007 \$\end{array} \\
759.187 \\
\end{array}$ & $\begin{array}{l}\begin{array}{c}\text { Bare Equip } \\
\text { cost in } 2007 \$\end{array} \\
\$ 307,363\end{array}$ & \begin{tabular}{|c} 
Equip Cost \\
Source
\end{tabular} \\
\hline E494 & 1 & 0 & Reformer Feed Preheater & Duty & $47,628,665$ & $37,339,000$ & BTU/h & 0.78 & $\$ 277,489$ & 2002 & $\mathrm{~b}$ & 0.65 & 2.47 & & & \\
\hline E444 & 1 & 0 & Reformed Syngas Cooler & Duty & $\begin{array}{l}155,010,82 \\
3\end{array}$ & $248,547,000$ & $\mathrm{BTU} / \mathrm{h}$ & 1.60 & $\$ 347,989$ & 2002 & $\mathrm{~b}$ & 0.65 & 2.47 & $1,515,855$ & $\$ 613,707$ & 1 \\
\hline E443 & 1 & 0 & Reformed Syngas Cooler & Duty & $13,974,577$ & $23,774,000$ & $\mathrm{BTU} / \mathrm{h}$ & 1.70 & $\$ 92,889$ & 2002 & $\mathrm{~b}$ & 0.65 & 2.47 & 420,506 & $\$ 170,245$ & 1 \\
\hline E442 & 1 & 0 & Reformed Syngas Cooler & Duty & $94,212,763$ & $45,839,000$ & BTU/h & 0.49 & $\$ 196,589$ & 2002 & $\mathrm{~b}$ & 0.65 & 2.47 & 394,460 & $\$ 159,700$ & 1 \\
\hline E446 & 1 & 0 & Air-cooled Precooler & Duty & $\begin{array}{l}149,281,59 \\
2\end{array}$ & $61,827,000$ & BTU/h & 0.41 & $\$ 388,064$ & 2002 & $\mathrm{~b}$ & 0.65 & 2.47 & 701,257 & $\$ 283,910$ & 1 \\
\hline E445 & 1 & 0 & Water-cooled Precooler & Duty & $\begin{aligned} 2 \\
8,414,338 \\
\end{aligned}$ & $7,743,000$ & BTU/h & 0.92 & $\$ 35,689$ & 2002 & $\mathrm{~b}$ & 0.65 & 2.47 & 108,361 & $\$ 43,871$ & 1 \\
\hline $\mathrm{C} 490$ & 1 & 0 & Reformer Combustion Air Blower & S490 & 304,578 & 286,107 & $\mathrm{lb} / \mathrm{h}$ & 0.94 & $\$ 35,020$ & 2002 & $\mathrm{~b}$ & 0.65 & 2.47 & 107,762 & $\$ 43,629$ & 1 \\
\hline R440 & 1 & 0 & Steam Reformer & Duty & $\begin{array}{l}158,705,74 \\
7\end{array}$ & $172,000,000$ & $\mathrm{BTU} / \mathrm{h}$ & 1.08 & $\$ 4,965,833$ & 2002 & $\mathrm{~b}$ & 0.65 & 2.47 & $16,769,199$ & $\$ 6,789,149$ & 1 \\
\hline $\mathrm{V} 450$ & 1 & 0 & Amine System (ISBL installed) & 5453 & 100,203 & 100,452 & $\mathrm{lb} / \mathrm{h} \mathrm{CO} 2$ & 1.00 & $\$ 15,400,000$ & 2003 & $\mathrm{i}$ & 0.65 & 2.47 & $19,695,479$ & $\$ 7,973,878$ & 4 \\
\hline $\begin{array}{l}\text { C470 } \\
\text { C471, } \\
\text { C472, } \\
\text { C473, } \\
\text { C474 }\end{array}$ & 1 & 0 & $\begin{array}{l}\text { Synthesis Feed Compressor with } \\
\text { interstage coolers included }\end{array}$ & & 8.40 & 8.26 & MW & 0.98 & $\$ 3,774,000$ & 2002 & $\mathrm{i}$ & 0.65 & 2.47 & $3,937,017$ & $\$ 1,593,934$ & 1 \\
\hline V449 & 1 & 0 & \begin{tabular}{|l|} 
Knock-out \#1 \\
\end{tabular} & S449 & 354,424 & 308,155 & $1 \mathrm{~b} / \mathrm{h}$ & 0.87 & $\$ 129,979$ & 2002 & $\mathrm{~b}$ & 0.65 & 2.47 & 380,360 & $\$ 153,992$ & 1 \\
\hline NS & 1 & 0 & Knock-out \#2 & S451 & 242,691 & 147,033 & $1 \mathrm{~b} / \mathrm{h}$ & 0.61 & $\$ 55,291$ & 2002 & & 0.65 & 2.47 & 127,938 & $\$ 51,797$ & 1 \\
\hline \multicolumn{17}{|c|}{$A 500 \& 600$} \\
\hline R500 & 1 & 0 & Mixed Alcohol Synthesis Reactor & 512 & 729,095 & 729,095 & $\mathrm{lb} / \mathrm{h}$ & 1.00 & $7,715,966$ & 1st Q 2005 & $\mathrm{b}$ & 0.65 & 2.47 & $20,934,508$ & $\$ 8,475,509$ & 2 \\
\hline E505 & 1 & 0 & Feed/Product Exchanger & AREA & 5,829 & 6,783 & $\mathrm{ft} 2$ & 1.16 & 158,400 & 1st Q 2005 & $\mathrm{b}$ & 0.65 & 2.47 & 474,259 & $\$ 192,008$ & 2 \\
\hline E506 & 1 & 0 & Product Air Cooler & $\mathrm{mmbtu} / \mathrm{h}$ & 104 & 114 & $\begin{array}{c}\text { MMBTU/ } \\
\mathrm{H}\end{array}$ & 1.10 & 419,400 & 1st Q 2005 & $\mathrm{b}$ & 0.65 & 2.47 & $1,207,862$ & $\$ 489,013$ & 2 \\
\hline E508 & 1 & 0 & \begin{tabular}{|l|} 
Product Trim Cooler \\
\end{tabular} & AREA & 2,706 & 3,105 & $\mathrm{ft} 2$ & 1.15 & 216,200 & 1st Q 2005 & $\mathrm{b}$ & 0.65 & 2.47 & 641,439 & $\$ 259,692$ & 2 \\
\hline V511 & 1 & 0 & High Pressure V-L Separator & 521 & 644,469 & $\frac{7,109}{729,107}$ & $\mathrm{lb} / \mathrm{h}$ & 1.13 & 99,100 & 1 st Q 2005 & $\mathrm{~b}$ & 0.05 & 2.47 & 291,326 & $\$ 117,946$ & $\frac{2}{2}$ \\
\hline V513 & 1 & 0 & Low Pressure V-L Separator & 525 & 78,114 & 78,542 & $\mathrm{lb} / \mathrm{h}$ & 1.01 & 19,300 & 1st Q 2005 & $\mathrm{b}$ & 0.65 & 2.47 & 52,550 & $\$ 21,275$ & 2 \\
\hline A-550 & 1 & 0 & High Pressure Amine Unit & 553 & 53,123 & 54,754 & $\mathrm{lb} / \mathrm{h} \mathrm{CO} 2$ & 1.03 & $\$ 10,900,000$ & 2003 & $\mathrm{i}$ & 0.65 & 2.47 & $14,194,115$ & $\$ 5,746,605$ & 4 \\
\hline C-551 & 1 & 0 & Recycle Compresser & S555 & $1,020,705$ & 569,788 & $\mathrm{lb} / \mathrm{h}$ & 0.56 & $1,002,900$ & $1 \mathrm{Q} 2005$ & $\mathrm{i}$ & 0.65 & 2.47 & 754,157 & $\$ 305,327$ & 2 \\
\hline E-560 & 1 & 0 & Recycle Methanol Vaporizer & area & 175 & 174 & $\mathrm{ft} 2$ & 0.99 & 19,700 & 1st Q 2005 & $\mathrm{b}$ & 0.65 & 2.47 & 53,250 & $\$ 21,559$ & 2 \\
\hline $\mathrm{P}-612$ & 1 & 0 & $\begin{array}{l}\text { Recycle Methanol Pump } \\
\end{array}$ & 612 & 12,414 & 12,274 & $1 \mathrm{lb} / \mathrm{h}$ & 0.99 & 0 & 1 st Q 2005 & $\mathrm{b}$ & 0.05 & 2.47 & 0 & \$o & $\frac{2}{2}$ \\
\hline MS620 & 1 & 0 & Molecular Sieve Alcohol Drier & 621 & 73,214 & 72,526 & $\mathrm{lb} / \mathrm{h}$ & 0.99 & $2,700,000$ & 1998 & $\mathrm{~b}$ & 0.65 & 2.47 & $8,734,926$ & $\$ 3,536,407$ & 3 \\
\hline T-601 & 1 & 0 & Light Ends Column & S528 & 73,801 & 74,279 & $\mathrm{lb} / \mathrm{h}$ & 1.01 & 271,800 & 1Q 2005 & $\mathrm{b}$ & 0.65 & 2.47 & 740,533 & $\$ 299,811$ & 2 \\
\hline $\mathrm{T}-610$ & 1 & 0 & Methanol Column & S624 & 64,269 & 64,813 & $1 \mathrm{lb} / \mathrm{h}$ & 1.01 & $1,604,500$ & 1Q 2005 & $\mathrm{b}$ & 0.65 & 2.47 & $4,377,151$ & $\$ 1,772,126$ & 2 \\
\hline $\mathrm{T}-630$ & 1 & 0 & Ethanol Column & S631 & 37,727 & 51,177 & $\mathrm{lb} / \mathrm{h}$ & 1.36 & 410,700 & 1Q 2005 & $\mathrm{b}$ & 0.65 & 2.47 & $1,358,538$ & $\$ 550,015$ & 2 \\
\hline $\mathrm{T}-640$ & 1 & 0 & Propanol Column & S641 & 7,748 & 12,927 & $\mathrm{lb} / \mathrm{h}$ & 1.67 & 183,400 & 1Q 2005 & $\mathrm{b}$ & 0.05 & 2.47 & 694,020 & $\$ 280,980$ & $\frac{2}{2}$ \\
\hline $\mathrm{T}-650$ & 1 & 0 & Butanol Column & S651 & 3,329 & 5,074 & $\mathrm{lb} / \mathrm{h}$ & 1.52 & 261,000 & 1Q 2005 & $\mathrm{~b}$ & 0.65 & 2.47 & 931,294 & $\$ 377,042$ & 2 \\
\hline E601 & 1 & 0 & Light Ends Column Condenser & DUTY & 8.46 & 11.78 & $\mathrm{mmbtu} / \mathrm{h}$ & 1.39 & $\$ 24,800$ & $1 \mathrm{Q} 2005$ & $\mathrm{~b}$ & 0.65 & 2.47 & 83,441 & $\$ 33,782$ & 2 \\
\hline $\mathrm{E} 602$ & 1 & 0 & Light Ends Column Reboiler & DUTY & 12.96 & 17.31 & $\mathrm{mmbtu} / \mathrm{h}$ & 1.34 & 104,900 & 1Q 2005 & $\mathrm{b}$ & 0.65 & 2.47 & 343,517 & $\$ 139,076$ & 2 \\
\hline E611 & 1 & 0 & Methanol Column Condenser & DUTY & 96.32 & 135.18 & $\mathrm{mmbtu} / \mathrm{h}$ & 1.40 & 54,100 & 1Q 2005 & $\mathrm{b}$ & 0.65 & 2.47 & 182,956 & $\$ 74,071$ & 2 \\
\hline E612 & 1 & 0 & Methanol Column Reboiler & DUTY & 96.42 & 135.36 & $\mathrm{mmbtu} / \mathrm{h}$ & 1.40 & 22,300 & 1Q2005 & $\mathrm{b}$ & 0.05 & 2.47 & 75,429 & $\$ 30,538$ & $\frac{2}{2}$ \\
\hline E631 & 1 & 0 & Ethanol Column Condenser & DUTY & 33.04 & 39.80 & $\mathrm{mmbtu} / \mathrm{h}$ & 1.20 & 5,800 & 1Q 2005 & $\mathrm{b}$ & 0.65 & 2.47 & 17,760 & $\$ 7,190$ & 2 \\
\hline E632 & 1 & 0 & Ethanol Column Reboiler & DUTY & 32.82 & 39.50 & $\mathrm{mmbtu} / \mathrm{h}$ & 1.20 & 52,500 & 1Q2005 & $\mathrm{b}$ & 0.65 & 2.47 & 160,668 & $\$ 65,048$ & 2 \\
\hline E641 & 1 & 0 & Propanol Column Condenser & DUTY & 5.76 & 6.87 & $\mathrm{mmbtu} / \mathrm{h}$ & 1.19 & 183,500 & 1Q 2005 & $\mathrm{b}$ & 0.65 & 2.47 & 558,285 & $\$ 226,026$ & 2 \\
\hline E642 & 1 & 0 & Propanol Column Reboiler & DUTY & 5.76 & 6.84 & $\mathrm{mmbtu} / \mathrm{h}$ & 1.19 & 123,300 & 1Q 2005 & $\mathrm{b}$ & 0.65 & 2.47 & 374,065 & $\$ 151,443$ & 2 \\
\hline E651 & 1 & 0 & \begin{tabular}{|l|} 
Butanol Column Condenser \\
\end{tabular} & DUTY & 2.11 & 2.52 & $\mathrm{mmbtu} / \mathrm{h}$ & 1.19 & 39,500 & 1Q 2005 & $\mathrm{b}$ & 0.65 & 2.47 & 120,281 & $\$ 48,697$ & 2 \\
\hline \multicolumn{17}{|c|}{$\mathrm{A} 700$} \\
\hline E740 & 1 & 0 & Extraction Steam Turbine/Generator & S725 & 342,283 & 285,364 & $\mathrm{lb} / \mathrm{h}$ & 0.83 & $\$ 4,045,870$ & 2002 & $\mathrm{~b}$ & 0.71 & 2.47 & $12,966,534$ & $\$ 5,249,609$ & 1 \\
\hline NS & 1 & 0 & Steam Turbine Condenser & & & & & & \multicolumn{5}{|c|}{$\begin{array}{l}\text { Included in the extraction steam turbine/generator cost } \\
\text { Int }\end{array}$} & & & 1 \\
\hline E770 & 1 & 0 & \begin{tabular}{|l} 
Blowdown Cooler / Deaerator Water \\
Preheater
\end{tabular} & & $2,877,029$ & $1,203,320$ & $\mathrm{mmbtu} / \mathrm{h}$ & 0.42 & $\$ 3,043$ & 2002 & $\mathrm{~b}$ & 0.6 & 2.47 & 9,752 & $\$ 3,948$ & 1 \\
\hline NS & 1 & 0 & Hot Process Water Softener System & S778 & 349,266 & 425,406 & $\mathrm{lb} / \mathrm{h}$ & 1.22 & $\$ 1,031,023$ & 1999 & $\mathrm{~b}$ & 0.82 & 2.47 & $3,346,604$ & $\$ 1,354,900$ & 1 \\
\hline NS & 1 & 0 & Startup Boiler & calculated & 36,560 & 36,560 & $\mathrm{lb} / \mathrm{h}$ & 1.00 & $\$ 198,351$ & 2002 & $\mathrm{~b}$ & 0.6 & 2.47 & 635,691 & $\$ 257,365$ & 1 \\
\hline & $\mathbf{0}$ & 0 & $\begin{array}{l}\text { Fuel Gas Steam Boiler (mult for higher } \\
\text { pressure) }\end{array}$ & $\begin{array}{l}\text { Scenario } \\
\text { dependent }\end{array}$ & & & $\mathrm{lb} / \mathrm{h}$ & 0.00 & $\$ 1,748,700$ & 1Q 2005 & $\mathrm{i}$ & 0.6 & 2.47 & 0 & $\$ 0$ & 2 \\
\hline NS & 1 & 1 & Collection Pump & S776 & 255,292 & 244,523 & $\mathrm{lb} / \mathrm{h}$ & 1.44 & $\$ 7,015$ & 2002 & $\mathrm{~b}$ & 0.33 & 2.47 & 44,964 & $\$ 18,204$ & 1 \\
\hline
\end{tabular}


Table A.3. (contd)

\begin{tabular}{|c|c|c|c|c|c|c|c|c|c|c|c|c|c|c|c|c|}
\hline $\begin{array}{l}\text { CC5 } \\
\text { Equip\# }\end{array}$ & \# Reqd & \# Spare & Equipment Name & $\begin{array}{c}\text { Scaling } \\
\text { Stream or } \\
\text { Factor }\end{array}$ & $\begin{array}{c}\text { Original } \\
\text { Stream } \\
\text { Flow } \\
\end{array}$ & $\begin{array}{l}\text { New Stream } \\
\text { Flow }\end{array}$ & $\begin{array}{c}\text { Stream } \\
\text { Flow Units } \\
\end{array}$ & $\begin{array}{r}\text { Size } \\
\text { Ratio }\end{array}$ & $\begin{array}{c}\text { Original Equip Cost } \\
\text { (per unit) }\end{array}$ & Base Year & $\begin{array}{l}\text { Installed (i) } \\
\text { or Bare (b) } \\
\end{array}$ & $\begin{array}{l}\text { Scaling } \\
\text { Exp }\end{array}$ & $\begin{array}{l}\text { Install } \\
\text { Factor } \\
\end{array}$ & $\begin{array}{c}\text { Installed Cost } \\
\text { in 2007\$ }\end{array}$ & $\begin{array}{c}\text { Bare Equip } \\
\text { cost in 2007\$ }\end{array}$ & $\begin{array}{l}\text { Equip Cost } \\
\text { Source }\end{array}$ \\
\hline NS & 1 & 1 & Condensate Pump & S761 & 93,974 & 64,246 & $\mathrm{lb} / \mathrm{h}$ & 0.25 & $\$ 5,437$ & 2002 & $\mathrm{~b}$ & 0.33 & 2.47 & 34,850 & $\$ 14,109$ & \\
\hline NS & 1 & 1 & Deaerator Feed Pump & $\begin{array}{llll}\text { S778 } & \end{array}$ & 349,266 & 425,406 & $\overline{l \mathrm{lb} / \mathrm{h}}$ & 4.53 & $\$ 8,679$ & 2002 & $\mathrm{~b}$ & 0.33 & 2.47 & 55,630 & $\$ 22,522$ & 1 \\
\hline P780 & 1 & 1 & Boiler Feed Water Pump & S778 & 349,268 & 425,406 & $\mathrm{lb} / \mathrm{h}$ & 1.22 & $\$ 95,660$ & 2002 & $\mathrm{~b}$ & 0.33 & 2.47 & 613,158 & $\$ 248,242$ & 1 \\
\hline NS & 1 & 0 & Condensate Collection Tank & S778 & 349,266 & 425,406 & $\mathrm{lb} / \mathrm{h}$ & 1.22 & $\$ 24,493$ & 2002 & $\mathrm{~b}$ & 0.6 & 2.47 & 78,497 & $\$ 31,780$ & 1 \\
\hline NS & 1 & 0 & Condensate Surge Drum & S778 & 349,268 & 425,406 & $\mathrm{lb} / \mathrm{h}$ & 1.22 & $\$ 28,572$ & 2002 & $\mathrm{~b}$ & 0.6 & 2.47 & 91,570 & $\$ 37,073$ & 1 \\
\hline V706 & 1 & 0 & Deaerator & S778 & 349,266 & 425,406 & $\mathrm{lb} / \mathrm{h}$ & 1.22 & $\$ 130,721$ & 2002 & $\mathrm{~b}$ & 0.72 & 2.47 & 418,945 & $\$ 169,613$ & 1 \\
\hline V700 & 1 & 0 & Steam Drum & S778 & 349,268 & 425,406 & $\mathrm{lb} / \mathrm{h}$ & 1.22 & $\$ 9,200$ & 1997 & $\mathrm{~b}$ & 0.72 & 2.47 & 30,179 & $\$ 12,218$ & 1 \\
\hline V703 & 1 & 0 & Blowdown Flash Drum & 5710 & 6,985 & 2,882 & $\mathrm{lb} / \mathrm{h}$ & 0.01 & $\$ 14,977$ & 2002 & $\mathrm{~b}$ & 0.6 & 2.47 & 48,001 & $\$ 19,434$ & 1 \\
\hline \multicolumn{17}{|c|}{ A900 } \\
\hline NS & 2 & 1 & Plant Air Compressor & S200 & 367,437 & 367,437 & $\mathrm{lb} / \mathrm{h}$ & 1.00 & $\$ 32,376$ & 2002 & $\mathrm{~b}$ & 0.34 & 2.47 & 311,286 & $\$ 126,027$ & 1 \\
\hline NS & 1 & 0 & Cooling Tower System & calculated & $\begin{array}{c}139,850,76 \\
3\end{array}$ & $81,483,762$ & $\mathrm{lb} / \mathrm{h}$ & 0.58 & $\$ 267,316$ & 2002 & $\mathrm{~b}$ & 0.78 & 2.47 & 856,716 & $\$ 346,849$ & 1 \\
\hline NS & 1 & 0 & Hydraulic Truck Dump with Scale & S200 & 367,437 & 367,437 & $\mathrm{lb} / \mathrm{h}$ & 1.00 & $\$ 80,000$ & 1998 & $\mathrm{~b}$ & 0.6 & 2.47 & 260,406 & $\$ 105,427$ & 1 \\
\hline NS & 1 & 0 & Flue Gas Stack & S380+S498 & $1,174,206$ & 693,431 & $1 \mathrm{~b} / \mathrm{h}$ & 0.59 & $\$ 51,581$ & 2002 & $\mathrm{~b}$ & 1 & 2.47 & 165,311 & $\$ 66,928$ & 1 \\
\hline NS & 1 & 1 & Cooling Water Pump & calculated & $6,088,320$ & $3,547,347$ & $1 \mathrm{~b} / \mathrm{h}$ & 0.58 & $\$ 158,540$ & 2002 & $\mathrm{~b}$ & 0.33 & 2.47 & $1,017,598$ & $\$ 411,983$ & 1 \\
\hline NS & 1 & 1 & Firewater Pump & S200 & 367,437 & 367,437 & $\mathrm{lb} / \mathrm{h}$ & 1.00 & $\$ 18,400$ & 1997 & $\mathrm{~b}$ & 0.79 & 2.47 & 120,716 & $\$ 48,873$ & 1 \\
\hline NS & 1 & 1 & Diesel Pump & S200 & 367,437 & 367,437 & $\mathrm{lb} / \mathrm{h}$ & 1.00 & $\$ 6,100$ & 1997 & $\mathrm{~b}$ & 0.79 & 2.47 & 40,020 & $\$ 16,202$ & 1 \\
\hline NS & 1 & 1 & Ammonia Pump & S200 & 367,437 & 367,437 & $\mathrm{lb} / \mathrm{h}$ & 1.00 & $\$ 6,100$ & 1997 & $\mathrm{~b}$ & 0.79 & 2.47 & 32,803 & $\$ 13,281$ & 1 \\
\hline NS & 1 & 0 & Hydrazine Pump & S200 & 367,437 & 367,437 & $\mathrm{lb} / \mathrm{h}$ & 1.00 & $\$ 5,500$ & 1997 & $\mathrm{~b}$ & 0.79 & 2.47 & 18,042 & $\$ 7,304$ & 1 \\
\hline NS & 1 & 1 & Instrument Air Dryer & S200 & 367,437 & 367,437 & $1 \mathrm{~b} / \mathrm{h}$ & 1.00 & $\$ 8,349$ & 2002 & $\mathrm{~b}$ & 0.6 & 2.47 & 53,515 & $\$ 21,666$ & 1 \\
\hline NS & 1 & 0 & Plant Air Receiver & S200 & 367,437 & 367,437 & $\mathrm{lb} / \mathrm{h}$ & 1.00 & $\$ 7,003$ & 2002 & $\mathrm{~b}$ & 0.72 & 2.47 & 22,444 & $\$ 99,087$ & 1 \\
\hline NS & 1 & 0 & Firewater Storage Tank & S200 & 367,437 & 367,437 & $\mathrm{lb} / \mathrm{h}$ & 1.00 & $\$ 166,100$ & 1997 & $\mathrm{~b}$ & 0.51 & 2.47 & 544,864 & $\$ 220,593$ & 1 \\
\hline NS & 1 & 0 & Diesel Storage Tank & S200 & 367,437 & $\begin{array}{l}367,437 \\
\end{array}$ & $1 \mathrm{~b} / \mathrm{h}$ & 1.00 & $\$ 14,400$ & 1997 & $\mathrm{~b}$ & 0.51 & 2.47 & 47,237 & $\$ 19,124$ & 1 \\
\hline NS & 1 & 0 & Ammonia Storage Tank & S200 & 367,437 & 367,437 & $1 \mathrm{~b} / \mathrm{h}$ & 1.00 & $\$ 287,300$ & 1997 & $\mathrm{~b}$ & 0.72 & 2.47 & 942,441 & $\$ 381,555$ & 1 \\
\hline NS & 1 & 0 & Hydrazine Storage Tank & $\begin{array}{lll}\text { S200 } & \end{array}$ & 367,437 & 367,437 & $\mathrm{lb} / \mathrm{h}$ & 1.00 & $\$ 12,400$ & 1997 & & 0.93 & 2.47 & 892,447 & $\$ 361,315$ & 1 \\
\hline
\end{tabular}





\section{Appendix B}

\section{Base Case Flow Sheets and Model Results}





\section{Appendix B}

\section{Base Case Flow Sheets and Model Results}

The Base Case flow diagrams and symbols generated in CHEMCAD are depicted in the following diagrams. An individual diagram is provided for each section. The equipment numbers are the same as those in Tables A.2 and A.3.

\section{B.1 Indirectly Heated Gasifier Model}

Figure B.1 shows the process flow diagram for the Base Case indirectly heated gasifier-based system. The flow sheet for each main area in the system is shown in Figures B.2 to B.7. The material and energy information for each unit operation and stream are summarized in Table B.1 


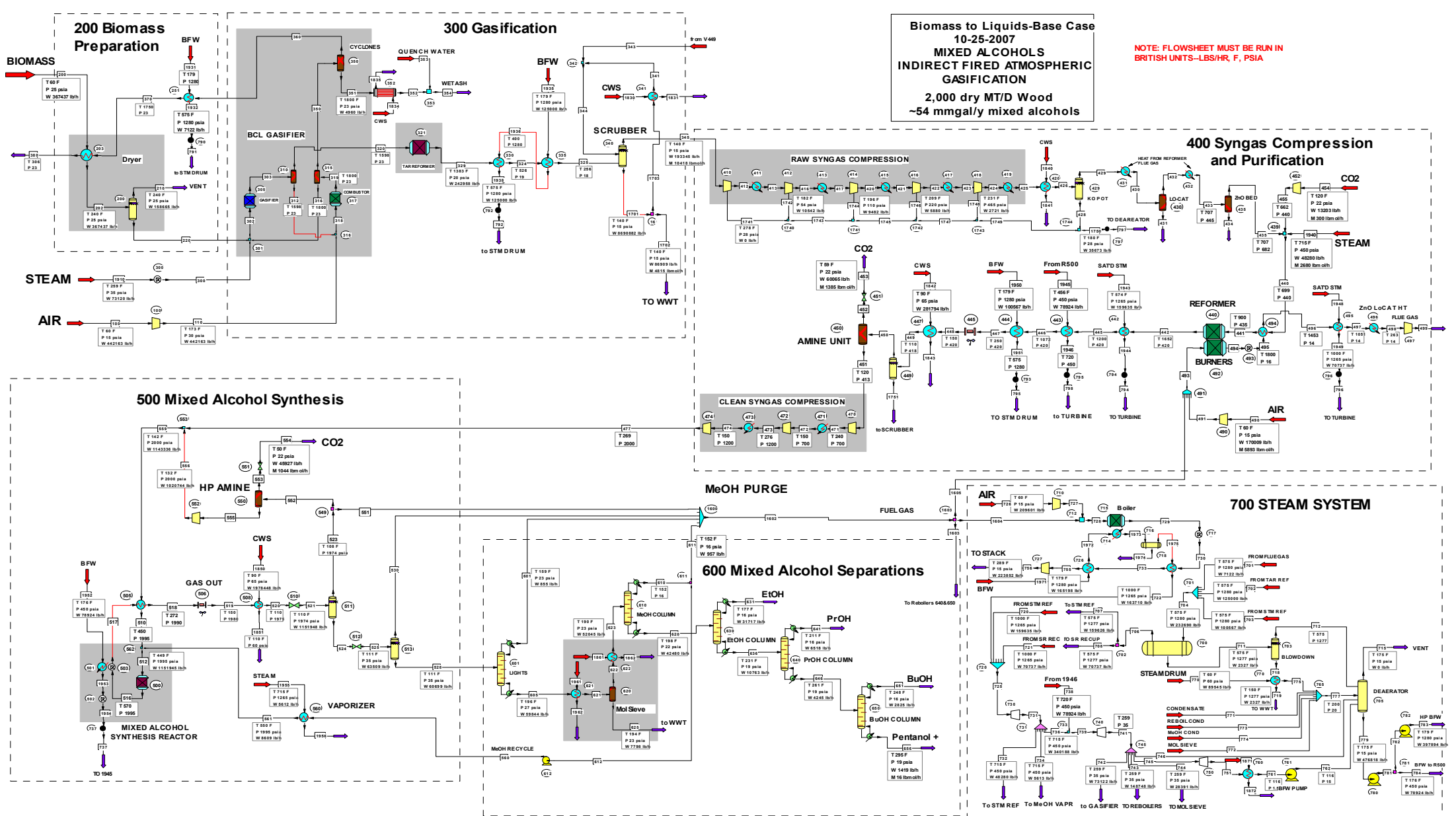

Figure B.1. Flow Sheet for Overall Mixed Alcohols Production System - Indirectly Heated Gasifier Base Case 


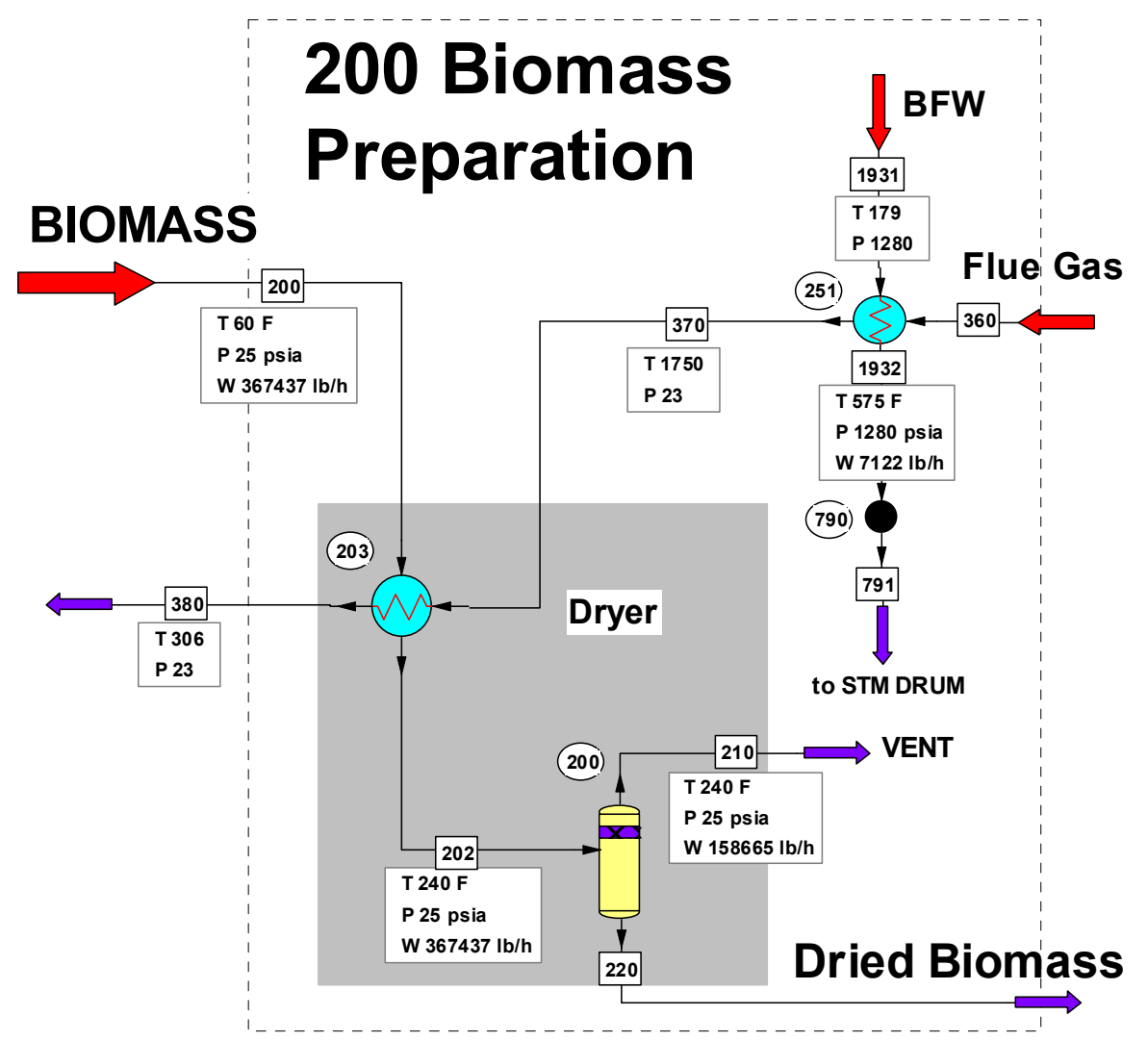

Figure B.2. Flow Sheet for Area 200 Biomass Preparation - Indirectly Heated Gasifier Base Case

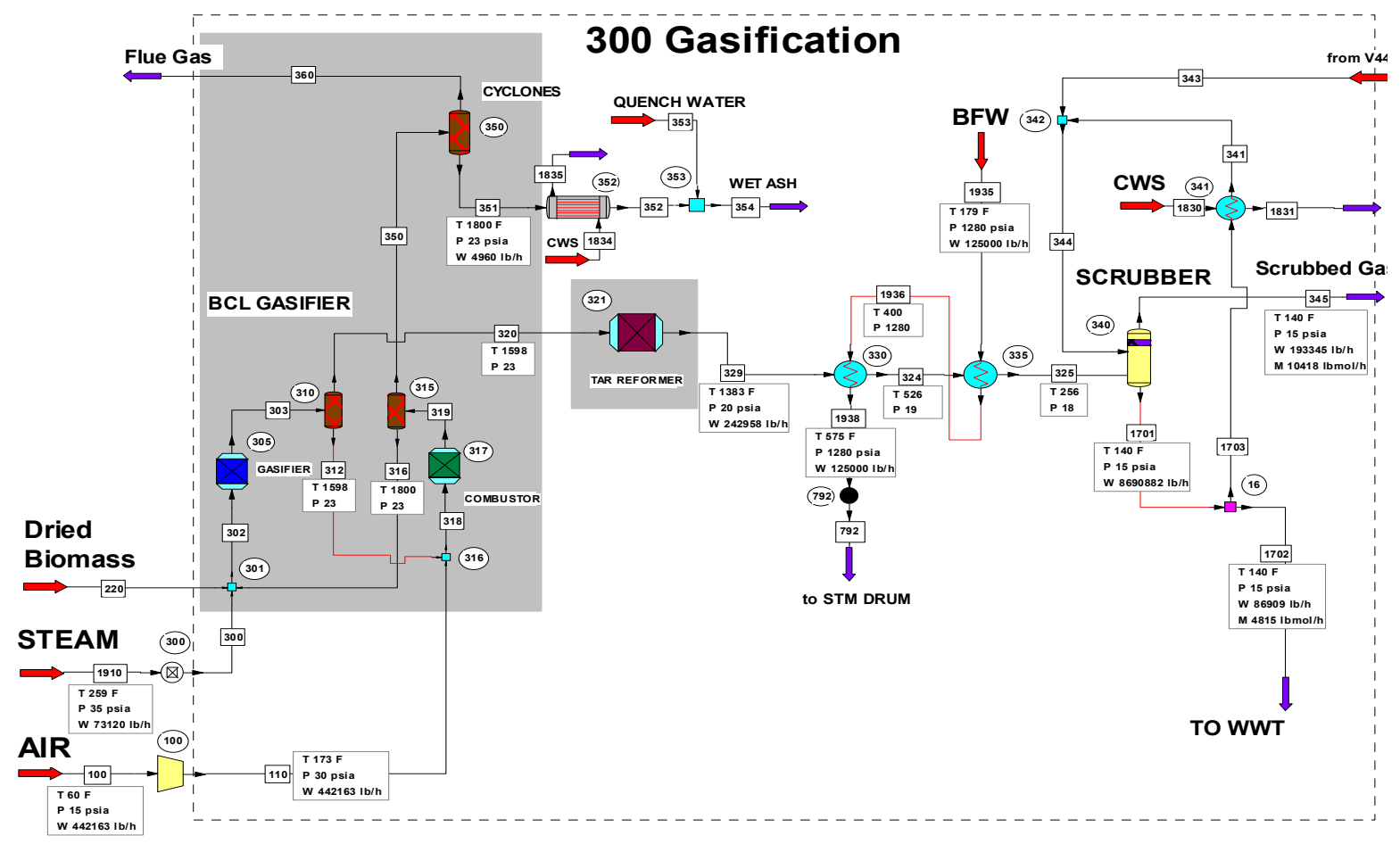

Figure B.3. Flow Sheet for Area 300 Gasification - Indirectly Heated Gasifier Base Case 


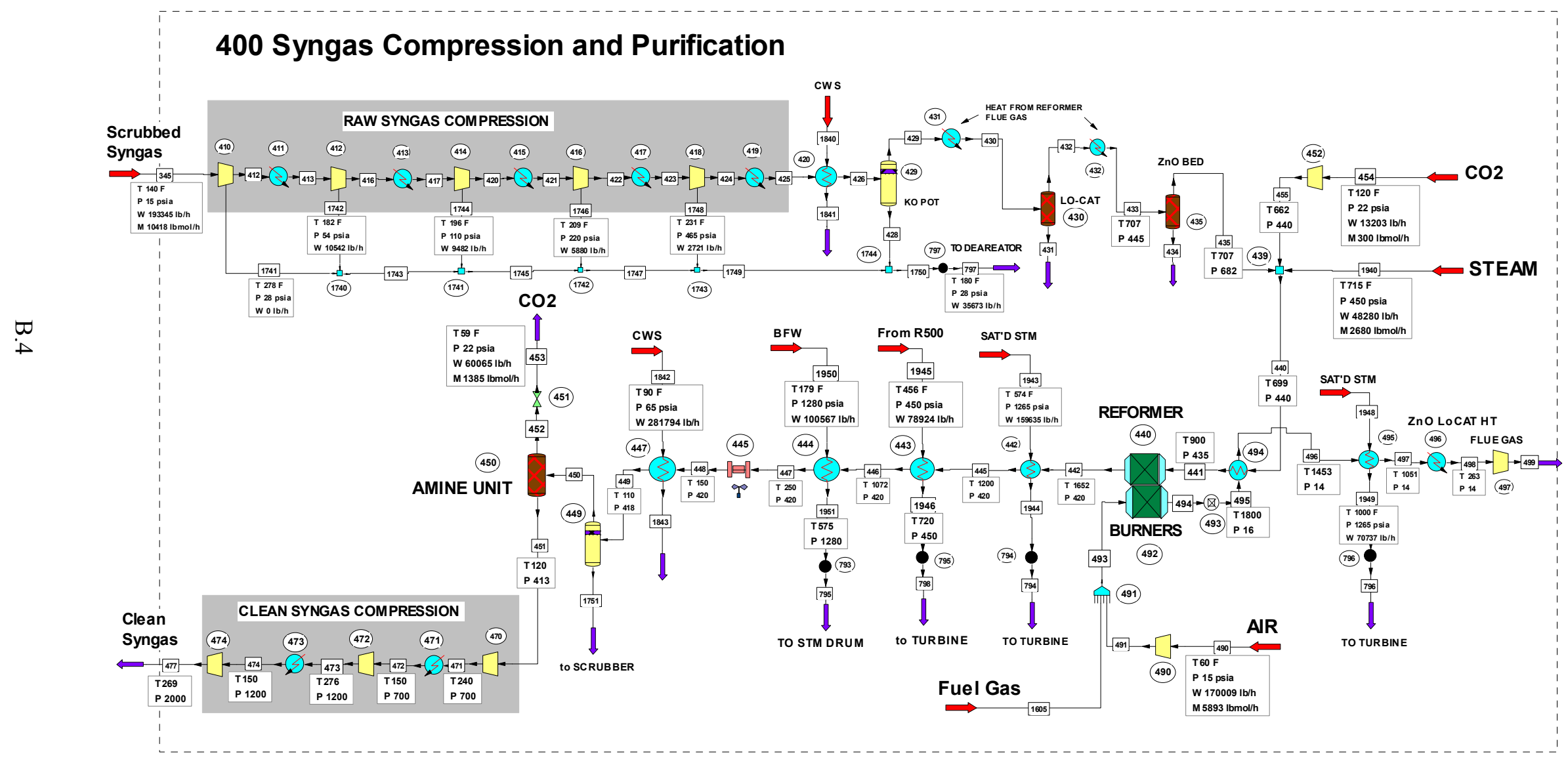

Figure B.4. Flow Sheet for Area 400 Syngas Compression and Purification - Indirectly Heated Gasifier Base Case 


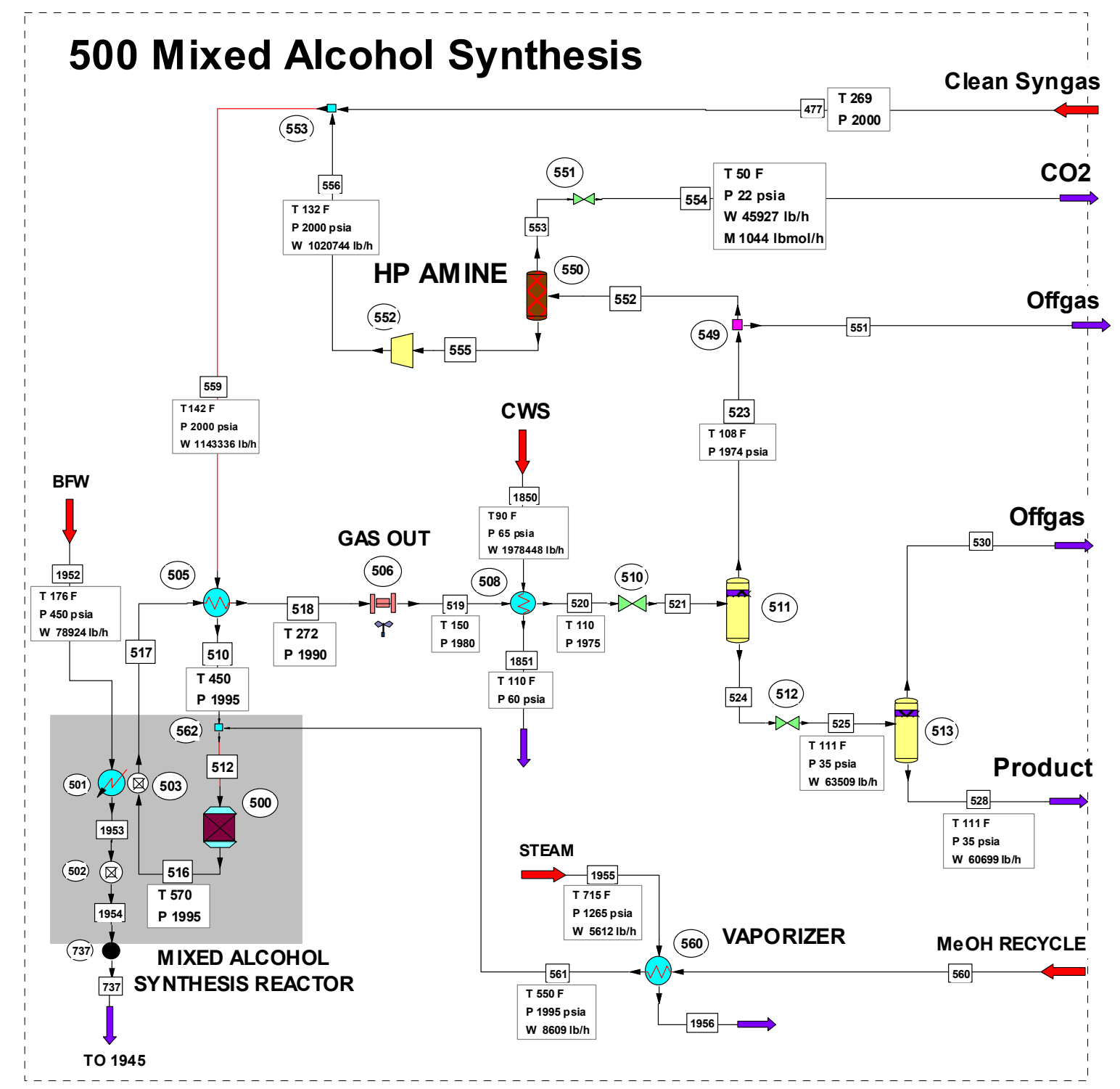

Figure B.5. Flow Sheet for Area 500 Mixed Alcohol Synthesis - Indirectly Heated Gasifier Base Case 


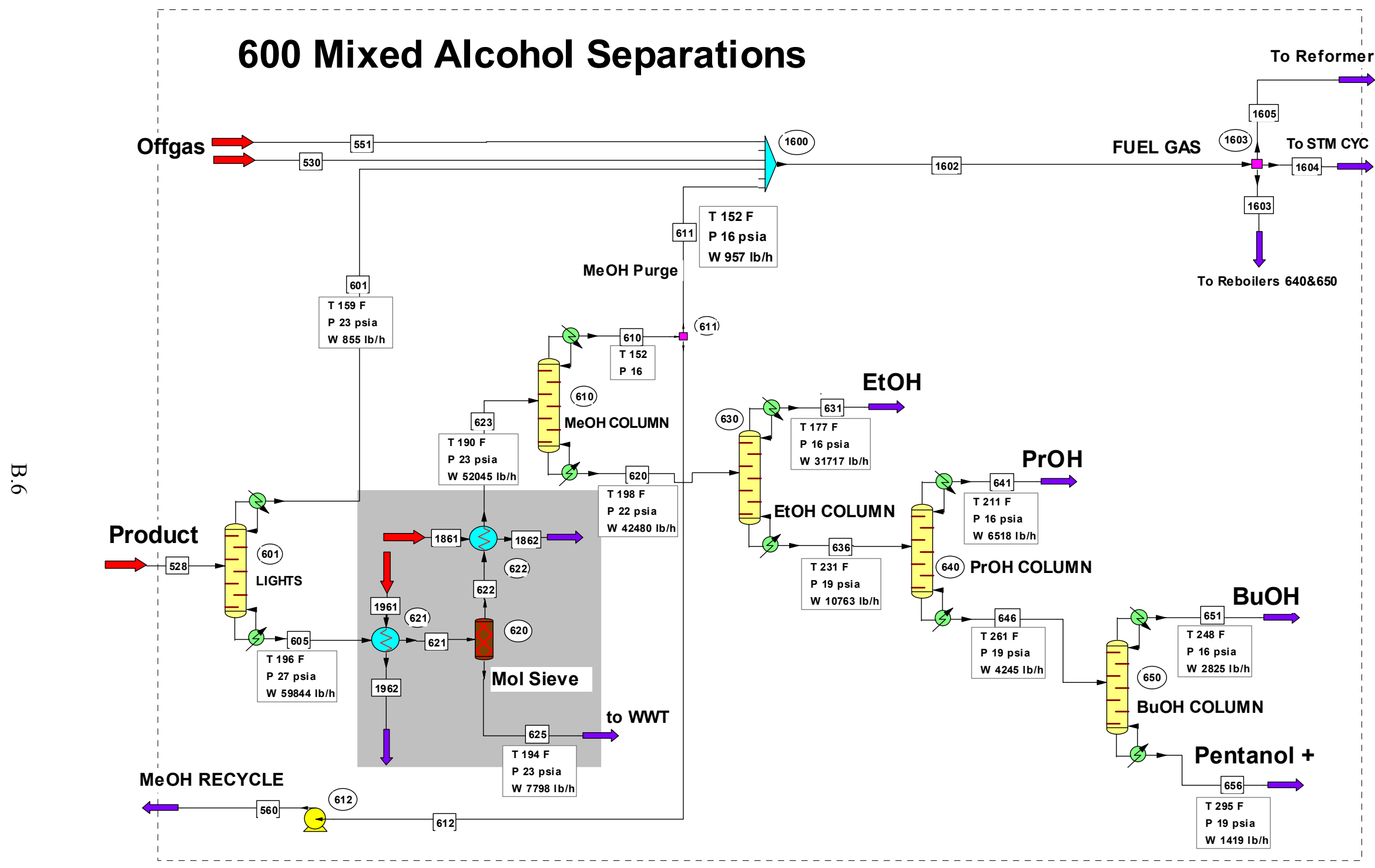

Figure B.6. Flow Sheet for Area 600 Mixed Alcohol Separation - Indirectly Heated Gasifier Base Case 


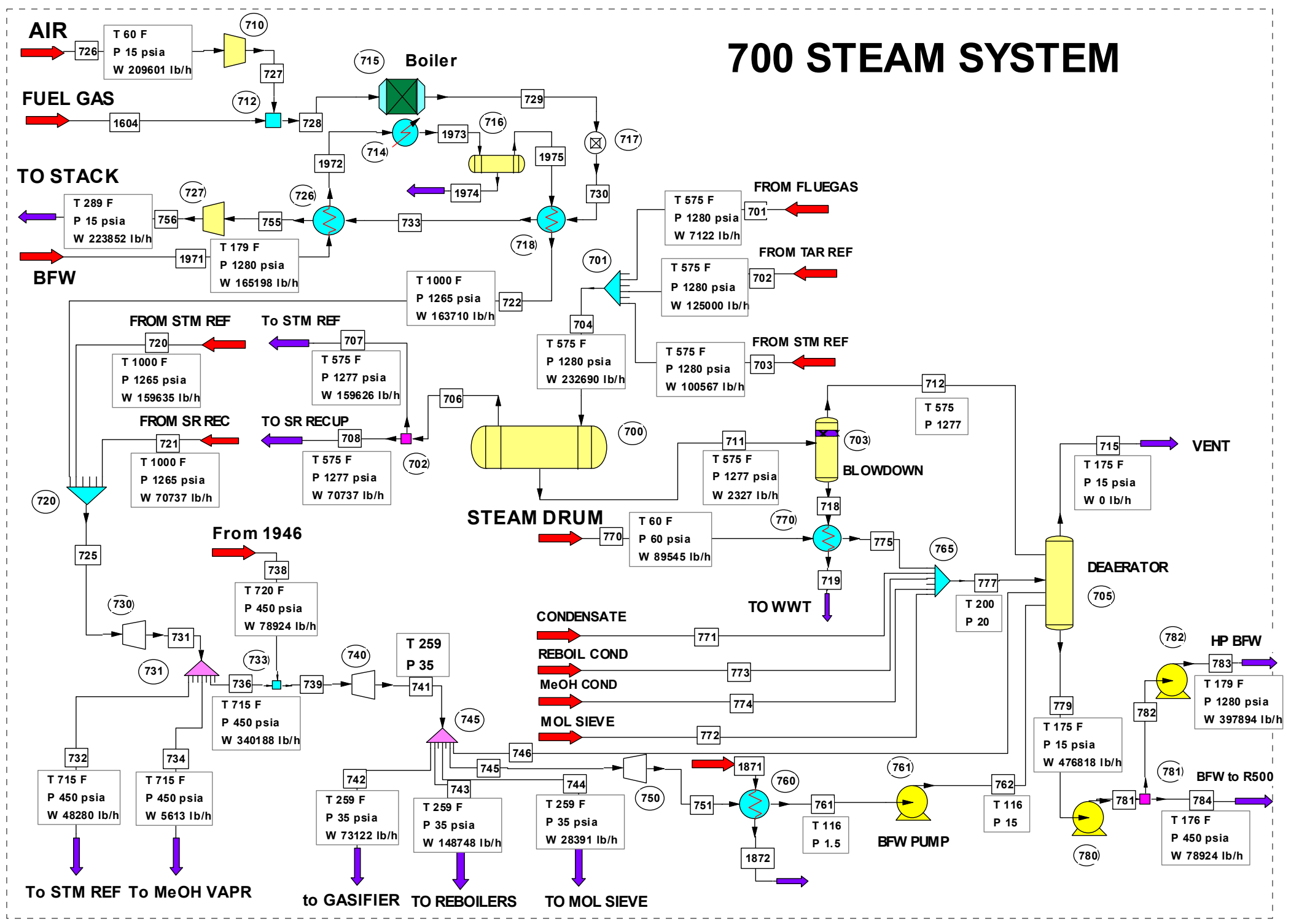

Figure B.7. Flow Sheet for Area 700 Steam System - Indirectly Heated Gasifier Base Case 
Table B.1. Heat and Material Balances for the Indirectly Heated Gasifier Base Case

\begin{tabular}{|c|c|c|c|c|c|c|c|c|c|c|c|c|c|c|}
\hline Stream No. & 100 & 110 & 200 & 202 & 210 & 220 & 300 & 302 & 303 & 312 & 316 & 318 & 319 & 320 \\
\hline Temp F & 60 & 172.5236 & 60 & 240.1082 & 240.1082 & 240.1082 & 259.3482 & 1675.4797 & 1598 & 1598 & 1800 & 1521.241 & 1800 & 1598 \\
\hline Pres psia & 14.696 & 30 & 25 & 25 & 25 & 25 & 35 & 23 & 23 & 23 & 23 & 23 & 23 & 23 \\
\hline Enth MMBtu/h & -56.586 & -40.388 & -1744.9 & -1549.6 & -906.07 & -643.52 & -417.08 & -9352.8 & -9437 & -8747.1 & -8292.2 & -8787.5 & -8653.4 & -689.85 \\
\hline Vapor mass fraction & 0.99137 & 1 & 0 & 0.86363 & 1 & 0 & 1 & 1 & 1 & 1 & 0 & 1 & 1 & 1 \\
\hline Total lb/h & 442163 & 442163 & 367437.406 & 367437.406 & 158664.734 & 208772.672 & 73120.0938 & 5268840.5 & 5268841 & 5025882.5 & 4986948 & 5468045.5 & 5468047.5 & 242958.406 \\
\hline \multicolumn{15}{|l|}{ Flowrates in $\mathrm{lb} / \mathrm{h}$} \\
\hline Oxygen & 100320.008 & 100320.008 & 0 & 0 & 0 & 0 & 0 & 0 & 3427.3118 & 3427.3118 & 0 & 103747.32 & 9939.2363 & 0 \\
\hline Nitrogen & 327414 & 327414 & 0 & 0 & 0 & 0 & 0 & 0 & 0 & 0 & 0 & 327414 & 327393 & 0 \\
\hline Argon & 5584 & 5584 & 0 & 0 & 0 & 0 & 0 & 0 & 0 & 0 & 0 & 5584 & 5584 & 0 \\
\hline Carbon & 0 & 0 & 0 & 0 & 0 & 0 & 0 & 0 & \begin{tabular}{|l|}
28194.9473 \\
\end{tabular} & 28194.9473 & 0 & 28194.9473 & 0.0012 & 0 \\
\hline Hydrogen & 0 & 0 & 0 & 0 & 0 & 0 & 0 & 0 & \begin{tabular}{|l|}
5458.3101 \\
\end{tabular} & 2351.679 & 0 & 2351.679 & 0.0007 & 3106.6311 \\
\hline Carbon Monoxide & 0 & 0 & 0 & 0 & 0 & 0 & 0 & 0 & \begin{tabular}{|l|}
76303.3672 \\
\end{tabular} & 0 & 0 & 0 & 0 & 76303.3672 \\
\hline Carbon Dioxide & 218 & 218 & 0 & 0 & 0 & 0 & 0 & 0 & 36358.2422 & 0 & 0 & 218 & 103532.289 & 36358.2422 \\
\hline Methane & 0 & 0 & 0 & 0 & 0 & 0 & 0 & 0 & 15913.6416 & 0 & 0 & 0 & 0 & 15913.6416 \\
\hline Acetylene & 0 & 0 & 0 & 0 & 0 & 0 & 0 & 0 & 685.7475 & 0 & 0 & 0 & 0 & 685.7475 \\
\hline Ethylene & 0 & 0 & 0 & 0 & 0 & 0 & 0 & 0 & 7877.7642 & 0 & 0 & 0 & 0 & 7877.7642 \\
\hline Ethane & 0 & 0 & 0 & 0 & 0 & 0 & 0 & 0 & 566.7108 & 0 & 0 & 0 & 0 & 566.7108 \\
\hline Propane & 0 & 0 & 0 & 0 & 0 & 0 & 0 & 0 & 0 & 0 & 0 & 0 & 0 & 0 \\
\hline Water & 8627 & 8627 & 183718.703 & 183718.703 & 158664.734 & 25053.9629 & 73120.0938 & 98174.0625 & 98174.0625 & 0 & 0 & 8627 & 29644.9277 & 98174.0625 \\
\hline Sulphur & 0 & 0 & 0 & 0 & 0 & 0 & 0 & 0 & 0 & 0 & 0 & 0 & 0 & 0 \\
\hline Carbonyl Sulfide & 0 & 0 & 0 & 0 & 0 & 0 & 0 & 0 & 0 & 0 & 0 & 0 & 0 & 0 \\
\hline Hydrogen Sulfide & 0 & 0 & 0 & 0 & 0 & 0 & 0 & 0 & 38.3004 & 0 & 0 & 0 & 0 & 38.3004 \\
\hline Ammonia & 0 & 0 & 0 & 0 & 0 & 0 & 0 & 0 & 1358.2247 & 0 & 0 & 0 & 0 & 1358.2247 \\
\hline HydrogenChloride & 0 & 0 & 0 & 0 & 0 & 0 & 0 & 0 & 18.5296 & 0 & 0 & 0 & 0 & 18.5296 \\
\hline Silicon Dioxide & 0 & 0 & 0 & 0 & 0 & 0 & 0 & 4986948 & 4986948 & 4986948 & 4986948 & 4986948 & 4986948 & 0 \\
\hline Calcium Oxide & 0 & 0 & 0 & 0 & 0 & 0 & 0 & 0 & 4960.4048 & 4960.4048 & 0 & 4960.4048 & 4960.4512 & 0 \\
\hline Benzene & 0 & 0 & 0 & 0 & 0 & 0 & 0 & 0 & 639.3005 & 0 & 0 & 0 & 0 & 639.3005 \\
\hline Naphthalene & 0 & 0 & 0 & 0 & 0 & 0 & 0 & 0 & 1917.9016 & 0 & 0 & 0 & 0 & 1917.9016 \\
\hline Hybrid Poplar Ch & 0 & 0 & 183718.703 & 183718.703 & 0 & 183718.703 & 0 & 183718.703 & 0.0041 & 0.0041 & 0 & 0.0041 & 0 & 0 \\
\hline \begin{tabular}{|l} 
Sulfur Dioxide \\
\end{tabular} & 0 & 0 & $\begin{array}{r}0 \\
\end{array}$ & 0 & 0 & $\begin{array}{r}0 \\
\end{array}$ & 0 & 0 & 0 & 0 & 0 & 0 & 0 & 0 \\
\hline Hydrogen Cyanide & 0 & 0 & 0 & 0 & 0 & 0 & 0 & 0 & 0 & 0 & 0 & 0 & 0 & 0 \\
\hline Nitric Oxide & 0 & 0 & 0 & 0 & 0 & 0 & 0 & 0 & 0 & 0 & 0 & 0 & 45.3622 & 0 \\
\hline Methanol & 0 & 0 & 0 & 0 & 0 & 0 & 0 & 0 & 0 & 0 & 0 & 0 & 0 & 0 \\
\hline Ethanol & 0 & 0 & 0 & 0 & 0 & 0 & 0 & 0 & 0 & 0 & 0 & 0 & 0 & 0 \\
\hline Isopropanol & 0 & 0 & 0 & 0 & 0 & 0 & 0 & 0 & 0 & 0 & 0 & 0 & 0 & 0 \\
\hline N-Propanol & 0 & 0 & 0 & 0 & 0 & 0 & 0 & 0 & 0 & 0 & 0 & 0 & 0 & 0 \\
\hline Isobutanol & 0 & 0 & 0 & 0 & 0 & 0 & 0 & 0 & 0 & 0 & 0 & 0 & 0 & 0 \\
\hline N-Butanol & 0 & 0 & 0 & 0 & 0 & 0 & 0 & 0 & 0 & 0 & 0 & 0 & 0 & 0 \\
\hline 1-Pentanol & 0 & 0 & 0 & 0 & 0 & 0 & 0 & 0 & 0 & 0 & 0 & 0 & 0 & 0 \\
\hline
\end{tabular}


Table B.1. (contd)

\begin{tabular}{|c|c|c|c|c|c|c|c|c|c|c|c|c|c|c|}
\hline Stream No. & 100 & 110 & 200 & 202 & 210 & 220 & 300 & 302 & 303 & 312 & 316 & 318 & 319 & 320 \\
\hline Temp F & 60 & 172.5236 & 60 & 240.1082 & 240.1082 & 240.1082 & 259.3482 & 1675.4797 & 1598 & 1598 & 1800 & 1521.241 & 1800 & 1598 \\
\hline Pres psia & 14.696 & 30 & 25 & 25 & 25 & 25 & 35 & 23 & 23 & 23 & 23 & 23 & 23 & 23 \\
\hline Enth MMBtu/h & -56.586 & -40.388 & -1744.9 & -1549.6 & -906.07 & -643.52 & -417.08 & -9352.8 & \begin{tabular}{|c|}
-9437 \\
\end{tabular} & $\mid-8747.1$ & -8292.2 & -8787.5 & -8653.4 & -689.85 \\
\hline Vapor mass fraction & 0.99137 & 1 & 0 & 0.86363 & 1 & 0 & 1 & 1 & 1 & 1 & 0 & 1 & 1 & 1 \\
\hline Total $\mathrm{lb} / \mathrm{h}$ & 442163 & 442163 & 367437.406 & 367437.406 & 158664.734 & 208772.672 & 73120.0938 & 5268840.5 & 5268841 & 5025882.5 & 4986948 & 5468045.5 & 5468047.5 & 242958.406 \\
\hline Flowrates in $\mathrm{lb} / \mathrm{h}$ & & & & & & & & & & & & & & \\
\hline Oxygen & 100320.008 & 100320.008 & 0 & 0 & 0 & 0 & 0 & 0 & 3427.3118 & 3427.3118 & 0 & 103747.32 & 9939.2363 & 0 \\
\hline Nitrogen & 327414 & 327414 & 0 & 0 & 0 & 0 & 0 & 0 & 0 & 0 & 0 & 327414 & 327393 & 0 \\
\hline Argon & 5584 & 5584 & 0 & 0 & $\overline{0}$ & 0 & 0 & 0 & 0 & 0 & 0 & 5584 & 5584 & $\overline{0}$ \\
\hline Carbon & 0 & 0 & 0 & 0 & $\overline{0}$ & 0 & 0 & 0 & 28194.9473 & 28194.9473 & 0 & 28194.9473 & 0.0012 & 0 \\
\hline Hydrogen & 0 & 0 & 0 & 0 & 0 & 0 & 0 & 0 & \begin{tabular}{|l|}
5458.3101 \\
\end{tabular} & 2351.679 & 0 & 2351.679 & 0.0007 & 3106.6311 \\
\hline Carbon Monoxide & 0 & 0 & 0 & 0 & 0 & 0 & 0 & 0 & 76303.3672 & 0 & 0 & 0 & 0 & 76303.3672 \\
\hline Carbon Dioxide & 218 & 218 & 0 & 0 & 0 & 0 & 0 & 0 & 36358.2422 & 0 & 0 & 218 & 103532.289 & 36358.2422 \\
\hline \begin{tabular}{|l} 
Methane \\
\end{tabular} & 0 & 0 & 0 & 0 & 0 & 0 & 0 & 0 & 15913.6416 & 0 & 0 & 0 & 0 & 15913.6416 \\
\hline Acetylene & 0 & 0 & 0 & 0 & 0 & 0 & 0 & 0 & 685.7475 & 0 & 0 & 0 & 0 & 685.7475 \\
\hline \begin{tabular}{|l|} 
Ethylene \\
\end{tabular} & 0 & 0 & 0 & 0 & 0 & 0 & 0 & 0 & 7877.7642 & 0 & 0 & 0 & 0 & 7877.7642 \\
\hline Ethane & 0 & 0 & 0 & 0 & 0 & 0 & 0 & 0 & 566.7108 & 0 & 0 & 0 & 0 & 566.7108 \\
\hline Propane & 0 & 0 & 0 & 0 & 0 & 0 & 0 & 0 & 0 & 0 & 0 & 0 & 0 & 0 \\
\hline \begin{tabular}{|l|} 
Water \\
\end{tabular} & 8627 & 8627 & 183718.703 & 183718.703 & 158664.734 & 25053.9629 & 73120.0938 & 98174.0625 & 98174.0625 & 0 & 0 & 8627 & 29644.9277 & 98174.0625 \\
\hline Sulphur & 0 & 0 & 0 & $\begin{array}{r}0 \\
\end{array}$ & 0 & 0 & 0 & $\begin{array}{r}0 \\
\end{array}$ & $\begin{array}{r}0 \\
\end{array}$ & 0 & 0 & 0 & 0 & 0 \\
\hline Carbonyl Sulfide & 0 & 0 & 0 & 0 & $\overline{0}$ & $\overline{0}$ & 0 & 0 & 0 & 0 & 0 & 0 & 0 & 0 \\
\hline Hydrogen Sulfide & 0 & 0 & 0 & 0 & 0 & 0 & 0 & 0 & 38.3004 & 0 & 0 & 0 & 0 & 38.3004 \\
\hline Ammonia & 0 & 0 & 0 & 0 & 0 & 0 & 0 & 0 & 1358.2247 & 0 & 0 & 0 & 0 & 1358.2247 \\
\hline HydrogenChloride & 0 & 0 & 0 & 0 & 0 & 0 & 0 & 0 & 18.5296 & 0 & 0 & 0 & 0 & 18.5296 \\
\hline Silicon Dioxide & 0 & 0 & 0 & 0 & 0 & 0 & 0 & 4986948 & 4986948 & 4986948 & 4986948 & 4986948 & 4986948 & 0 \\
\hline \begin{tabular}{|l|} 
Calcium Oxide \\
\end{tabular} & 0 & 0 & 0 & 0 & 0 & 0 & 0 & 0 & 4960.4048 & 4960.4048 & 0 & 4960.4048 & 4960.4512 & 0 \\
\hline Benzene & 0 & 0 & 0 & 0 & $\overline{0}$ & 0 & 0 & 0 & 639.3005 & 0 & 0 & 0 & 0 & 639.3005 \\
\hline Naphthalene & 0 & 0 & 0 & 0 & $\overline{0}$ & 0 & 0 & 0 & 1917.9016 & 0 & 0 & 0 & 0 & 1917.9016 \\
\hline Hybrid Poplar Ch & 0 & 0 & 183718.703 & \begin{tabular}{|l|}
183718.703 \\
\end{tabular} & 0 & 183718.703 & 0 & 183718.703 & o.0041 & 0.0041 & 0 & 0.0041 & 0 & 0 \\
\hline \begin{tabular}{|l} 
Sulfur Dioxide \\
\end{tabular} & 0 & 0 & $\begin{array}{r}0 \\
\end{array}$ & $\begin{array}{r}0 \\
\end{array}$ & 0 & 0 & 0 & 0 & 0 & 0 & 0 & 0 & 0 & 0 \\
\hline Hydrogen Cyanide & 0 & 0 & 0 & 0 & 0 & 0 & 0 & 0 & 0 & 0 & 0 & 0 & 0 & 0 \\
\hline Nitric Oxide & 0 & 0 & 0 & 0 & 0 & 0 & 0 & 0 & 0 & 0 & 0 & 0 & 45.3622 & 0 \\
\hline Methanol & 0 & 0 & 0 & 0 & 0 & 0 & 0 & 0 & 0 & 0 & 0 & 0 & 0 & 0 \\
\hline Ethanol & 0 & 0 & 0 & 0 & 0 & 0 & 0 & 0 & 0 & 0 & 0 & 0 & 0 & 0 \\
\hline Isopropanol & 0 & 0 & 0 & 0 & 0 & 0 & 0 & 0 & 0 & 0 & 0 & 0 & 0 & 0 \\
\hline N-Propanol & 0 & 0 & 0 & 0 & 0 & 0 & 0 & 0 & 0 & 0 & 0 & 0 & 0 & 0 \\
\hline Isobutanol & 0 & 0 & 0 & 0 & 0 & 0 & 0 & 0 & 0 & 0 & 0 & 0 & 0 & 0 \\
\hline \begin{tabular}{|l|} 
N-Butanol \\
\end{tabular} & 0 & 0 & 0 & 0 & 0 & 0 & 0 & 0 & 0 & 0 & 0 & 0 & 0 & 0 \\
\hline 1-Pentanol & 0 & 0 & 0 & 0 & $\overline{0}$ & 0 & 0 & 0 & 0 & 0 & 0 & 0 & 0 & 0 \\
\hline
\end{tabular}


Table B.1. (contd)

\begin{tabular}{|c|c|c|c|c|c|c|c|c|c|c|c|c|c|c|}
\hline Stream No. & 100 & 110 & 200 & 202 & 210 & 220 & 300 & 302 & 303 & 312 & 316 & 318 & 319 & 320 \\
\hline Temp F & 60 & 172.5236 & 60 & 240.1082 & 240.1082 & 240.1082 & 259.3482 & 1675.4797 & 1598 & 1598 & 1800 & 1521.241 & 1800 & 1598 \\
\hline Pres psia & 14.696 & 30 & 25 & 25 & 25 & 25 & 35 & 23 & 23 & 23 & 23 & 23 & 23 & 23 \\
\hline Enth MMBtu/h & -56.586 & -40.388 & -1744.9 & -1549.6 & -906.07 & -643.52 & -417.08 & -9352.8 & \begin{tabular}{|c|}
-9437 \\
\end{tabular} & $\mid-8747.1$ & -8292.2 & -8787.5 & -8653.4 & -689.85 \\
\hline Vapor mass fraction & 0.99137 & 1 & 0 & 0.86363 & 1 & 0 & 1 & 1 & 1 & 1 & 0 & 1 & 1 & 1 \\
\hline Total $\mathrm{lb} / \mathrm{h}$ & 442163 & 442163 & 367437.406 & 367437.406 & 158664.734 & 208772.672 & 73120.0938 & 5268840.5 & 5268841 & 5025882.5 & 4986948 & 5468045.5 & 5468047.5 & 242958.406 \\
\hline Flowrates in $\mathrm{lb} / \mathrm{h}$ & & & & & & & & & & & & & & \\
\hline Oxygen & 100320.008 & 100320.008 & 0 & 0 & 0 & 0 & 0 & 0 & 3427.3118 & 3427.3118 & 0 & 103747.32 & 9939.2363 & 0 \\
\hline Nitrogen & 327414 & 327414 & 0 & 0 & 0 & 0 & 0 & 0 & 0 & 0 & 0 & 327414 & 327393 & 0 \\
\hline Argon & 5584 & 5584 & 0 & 0 & $\overline{0}$ & 0 & 0 & 0 & 0 & 0 & 0 & 5584 & 5584 & $\overline{0}$ \\
\hline Carbon & 0 & 0 & 0 & 0 & 0 & 0 & 0 & 0 & 28194.9473 & 28194.9473 & 0 & 28194.9473 & 0.0012 & 0 \\
\hline Hydrogen & 0 & 0 & 0 & 0 & 0 & 0 & 0 & 0 & 5458.3101 & \begin{tabular}{|l|}
2351.679 \\
\end{tabular} & 0 & 2351.679 & 0.0007 & 3106.6311 \\
\hline Carbon Monoxide & 0 & 0 & 0 & 0 & 0 & 0 & 0 & 0 & 76303.3672 & 0 & 0 & 0 & 0 & 76303.3672 \\
\hline Carbon Dioxide & 218 & 218 & 0 & 0 & 0 & 0 & 0 & 0 & 36358.2422 & 0 & 0 & 218 & 103532.289 & 36358.2422 \\
\hline Methane & 0 & 0 & 0 & 0 & 0 & 0 & 0 & 0 & 15913.6416 & 0 & 0 & 0 & 0 & 15913.6416 \\
\hline Acetylene & 0 & 0 & 0 & 0 & 0 & 0 & 0 & 0 & 685.7475 & 0 & 0 & 0 & 0 & 685.7475 \\
\hline \begin{tabular}{|l|} 
Ethylene \\
\end{tabular} & 0 & 0 & 0 & 0 & 0 & 0 & 0 & 0 & 7877.7642 & 0 & 0 & 0 & 0 & 7877.7642 \\
\hline Ethane & 0 & 0 & 0 & 0 & 0 & 0 & 0 & 0 & 566.7108 & 0 & 0 & 0 & 0 & 566.7108 \\
\hline Propane & 0 & 0 & 0 & 0 & 0 & 0 & 0 & 0 & 0 & 0 & 0 & 0 & 0 & 0 \\
\hline Water & 8627 & 8627 & 183718.703 & 183718.703 & 158664.734 & 25053.9629 & 73120.0938 & 98174.0625 & 98174.0625 & 0 & 0 & 8627 & 29644.9277 & 98174.0625 \\
\hline Sulphur & 0 & 0 & 0 & 0 & 0 & 0 & 0 & $\begin{array}{r}0 \\
\end{array}$ & $\begin{array}{r}0 \\
\end{array}$ & 0 & 0 & 0 & 0 & 0 \\
\hline Carbonyl Sulfide & 0 & 0 & 0 & $\overline{0}$ & $\overline{0}$ & $\overline{0}$ & 0 & 0 & 0 & 0 & 0 & 0 & 0 & 0 \\
\hline Hydrogen Sulfide & 0 & 0 & 0 & 0 & 0 & 0 & 0 & 0 & 38.3004 & 0 & 0 & 0 & 0 & 38.3004 \\
\hline Ammonia & 0 & 0 & 0 & 0 & 0 & 0 & 0 & 0 & 1358.2247 & 0 & 0 & 0 & 0 & 1358.2247 \\
\hline HydrogenChloride & 0 & 0 & 0 & 0 & 0 & 0 & 0 & 0 & 18.5296 & 0 & 0 & 0 & 0 & 18.5296 \\
\hline Silicon Dioxide & 0 & 0 & 0 & 0 & 0 & 0 & 0 & 4986948 & 4986948 & 4986948 & 4986948 & 4986948 & 4986948 & 0 \\
\hline \begin{tabular}{|l|} 
Calcium Oxide \\
\end{tabular} & 0 & 0 & 0 & 0 & 0 & 0 & 0 & 0 & 4960.4048 & 4960.4048 & 0 & 4960.4048 & 4960.4512 & 0 \\
\hline Benzene & 0 & 0 & 0 & 0 & $\overline{0}$ & 0 & 0 & 0 & 639.3005 & 0 & 0 & 0 & 0 & 639.3005 \\
\hline Naphthalene & 0 & 0 & 0 & 0 & $\overline{0}$ & 0 & 0 & 0 & 1917.9016 & 0 & 0 & 0 & 0 & 1917.9016 \\
\hline Hybrid Poplar Ch & 0 & 0 & 183718.703 & 183718.703 & 0 & 183718.703 & 0 & 183718.703 & o.0041 & 0.0041 & 0 & 0.0041 & 0 & 0 \\
\hline \begin{tabular}{|l} 
Sulfur Dioxide \\
\end{tabular} & 0 & 0 & $\begin{array}{r}0 \\
\end{array}$ & 0 & 0 & 0 & 0 & 0 & 0 & 0 & 0 & 0 & 0 & 0 \\
\hline Hydrogen Cyanide & 0 & 0 & 0 & 0 & 0 & 0 & 0 & 0 & 0 & 0 & 0 & 0 & 0 & 0 \\
\hline Nitric Oxide & 0 & 0 & 0 & 0 & 0 & 0 & 0 & 0 & 0 & 0 & 0 & 0 & 45.3622 & 0 \\
\hline Methanol & 0 & 0 & 0 & 0 & 0 & 0 & 0 & 0 & 0 & 0 & 0 & 0 & 0 & 0 \\
\hline Ethanol & 0 & 0 & 0 & 0 & 0 & 0 & 0 & 0 & 0 & 0 & 0 & 0 & 0 & 0 \\
\hline Isopropanol & 0 & 0 & 0 & 0 & 0 & 0 & 0 & 0 & 0 & 0 & 0 & 0 & 0 & 0 \\
\hline N-Propanol & 0 & 0 & 0 & 0 & 0 & 0 & 0 & 0 & 0 & 0 & 0 & 0 & 0 & 0 \\
\hline Isobutanol & 0 & 0 & 0 & 0 & 0 & 0 & 0 & 0 & 0 & 0 & 0 & 0 & 0 & 0 \\
\hline \begin{tabular}{|l|} 
N-Butanol \\
\end{tabular} & 0 & 0 & 0 & 0 & 0 & 0 & 0 & 0 & 0 & 0 & 0 & 0 & 0 & 0 \\
\hline 1-Pentanol & 0 & 0 & 0 & $\overline{0}$ & $\overline{0}$ & 0 & 0 & 0 & 0 & 0 & 0 & 0 & 0 & 0 \\
\hline
\end{tabular}


Table B.1. (contd)

\begin{tabular}{|c|c|c|c|c|c|c|c|c|c|c|c|c|c|c|}
\hline Stream No. & 430 & 431 & 432 & 433 & 434 & 435 & 440 & 441 & 442 & 445 & 446 & 447 & 448 & 449 \\
\hline Temp F & 120 & 120 & 120 & 707 & 707 & 707 & 699.2361 & 900 & 1652 & 1199.951 & 1071.6383 & 250 & 150 & 110 \\
\hline Pres psia & 465 & 445 & 445 & 445 & 682 & 682 & 440 & 435 & 420 & 420 & 420 & 420 & 420 & 417.5 \\
\hline Enth MMBtu/h & -323.82 & 0 & -323.8 & -284.05 & -0.0039727 & -283.97 & -598.63 & -578.52 & -477.68 & -528.02 & -541.77 & -645.73 & -668.71 & -674.35 \\
\hline Vapor mass fraction & 1 & 0 & 1 & 1 & 1 & 1 & 1 & 1 & 1 & 1 & 1 & 0.89505 & 0.83868 & 0.83361 \\
\hline Total lb/h & 157674.781 & 0 & 157674.781 & \begin{tabular}{|l|l|}
157674.781 \\
\end{tabular} & 37.8475 & 157637 & 219120.125 & 219120.125 & 219120.469 & \begin{tabular}{|l|}
219120.469 \\
\end{tabular} & \begin{tabular}{|l|}
219120.469 \\
\end{tabular} & 219120.469 & 219120.469 & 219120.469 \\
\hline Flowrates in $\mathrm{lb} / \mathrm{h}$ & & & & & & & & & & & & & & \\
\hline Oxygen & 0 & 0 & 0 & 0 & 0 & 0 & 0 & 0 & 0 & 0 & 0 & 0 & 0 & 0 \\
\hline Nitrogen & 781.9396 & 0 & 781.9396 & 781.9396 & 0 & 781.9396 & 781.9396 & 781.9396 & 976.8055 & 976.8055 & 976.8055 & 976.8055 & 976.8055 & 976.8055 \\
\hline Argon & 0 & 0 & 0 & 0 & 0 & 0 & 0 & 0 & 0 & 0 & 0 & 0 & 0 & 0 \\
\hline Carbon & 0 & 0 & $\begin{array}{r}0 \\
\end{array}$ & 0 & 0 & 0 & 0 & 0 & 0 & 0 & 0 & 0 & 0 & 0 \\
\hline Hydrogen & 6362.9224 & 0 & \begin{tabular}{|l|}
6362.9224 \\
\end{tabular} & \begin{tabular}{|l|}
6362.9224 \\
\end{tabular} & 0 & 6362.9224 & 6362.9224 & 6362.9224 & 8615.5762 & 8615.5762 & 8615.5762 & 8615.5762 & 8615.5762 & 8615.5762 \\
\hline Carbon Monoxide & \begin{tabular}{|l|l}
96357.4766 \\
\end{tabular} & 0 & \begin{tabular}{|l|}
96357.4766 \\
\end{tabular} & \begin{tabular}{|l|l}
96357.4766 \\
\end{tabular} & 0 & \begin{tabular}{|l|}
96357.4766 \\
\end{tabular} & \begin{tabular}{|l|}
96357.4766 \\
\end{tabular} & \begin{tabular}{|l|}
96357.4766 \\
\end{tabular} & \begin{tabular}{|l|}
100748.828 \\
\end{tabular} & \begin{tabular}{|l|}
100748.828 \\
\end{tabular} & \begin{tabular}{|l|}
100748.828 \\
\end{tabular} & 100748.828 & 100748.828 & 100748.828 \\
\hline Carbon Dioxide & \begin{tabular}{|l|}
36047.4688 \\
\end{tabular} & 0 & \begin{tabular}{|l|}
36047.4688 \\
\end{tabular} & \begin{tabular}{|l|}
36047.4688 \\
\end{tabular} & 0 & \begin{tabular}{|l|}
36047.4688 \\
\end{tabular} & 49250.4648 & \begin{tabular}{|l|}
49250.4648 \\
\end{tabular} & \begin{tabular}{|l|}
60059.4336 \\
\end{tabular} & \begin{tabular}{|l|}
60059.4336 \\
\end{tabular} & \begin{tabular}{|l|l|}
60059.4336 \\
\end{tabular} & 60059.4336 & 60059.4336 & 60059.4336 \\
\hline Methane & \begin{tabular}{|l|}
12730.8164 \\
\end{tabular} & 0 & 12730.8164 & \begin{tabular}{|l|}
12730.8164 \\
\end{tabular} & 0 & \begin{tabular}{|l|}
12730.8164 \\
\end{tabular} & 12730.8164 & \begin{tabular}{|l|}
12730.8164 \\
\end{tabular} & 11616.4678 & \begin{tabular}{|l|}
11616.4678 \\
\end{tabular} & \begin{tabular}{|l|}
11616.4678 \\
\end{tabular} & 11616.4678 & 11616.4678 & \begin{tabular}{|l|}
11616.4678 \\
\end{tabular} \\
\hline Acetylene & \begin{tabular}{|l|}
342.8701 \\
\end{tabular} & 0 & 342.8701 & \begin{tabular}{|l|}
342.8701 \\
\end{tabular} & 0 & \begin{tabular}{|l|}
342.8701 \\
\end{tabular} & 342.8701 & 342.8701 & \begin{tabular}{|l|}
0.0034 \\
\end{tabular} & \begin{tabular}{|l|}
0.0034 \\
\end{tabular} & $\begin{array}{l}0.0034 \\
\end{array}$ & 0.0034 & 0.0034 & 0.0034 \\
\hline Ethylene & 3938.7883 & 0 & 3938.7883 & \begin{tabular}{|c|}
3938.7883 \\
\end{tabular} & 0 & 3938.7883 & 3938.7883 & 3938.7883 & 0.8319 & 0.8319 & 0.8319 & 0.8319 & 0.8319 & 0.8319 \\
\hline Ethane & $\begin{array}{r}56.6707 \\
\end{array}$ & 0 & 56.6707 & \begin{tabular}{|l|}
56.6707 \\
\end{tabular} & 0 & 56.6707 & 56.6707 & 56.6707 & 2.0757 & 2.0757 & 2.0757 & 2.0757 & 2.0757 & 2.0757 \\
\hline Propane & 0 & 0 & 0 & 0 & 0 & 0 & 0 & 0 & 0 & 0 & 0 & 0 & 0 & 0 \\
\hline Water & 458.8869 & 0 & 458.8869 & 458.8869 & 0 & 458.8869 & 48739.082 & 48739.082 & \begin{tabular}{|l|}
37065.7852 \\
\end{tabular} & 37065.7852 & \begin{tabular}{|l|}
37065.7852 \\
\end{tabular} & 37065.7852 & 37065.7852 & 37065.7852 \\
\hline Sulphur & 0 & 0 & 0 & 0 & 0 & 0 & 0 & 0 & 0 & \begin{tabular}{r|}
0 \\
\end{tabular} & $\begin{array}{r}0 \\
\end{array}$ & 0 & 0 & 0 \\
\hline Carbonyl Sulfide & 0 & 0 & 0 & 0 & 0 & 0 & 0 & 0 & 0 & 0 & 0 & 0 & 0 & 0 \\
\hline Hydrogen Sulfide & 37.8475 & 0 & 37.8475 & 37.8475 & 37.8475 & 0 & 0 & 0 & 0 & 0 & 0 & 0 & 0 & 0 \\
\hline Ammonia & 252.8876 & 0 & 252.8876 & 252.8876 & 0 & 252.8876 & 252.8876 & 252.8876 & 15.7244 & 15.7244 & 15.7244 & 15.7244 & 15.7244 & 15.7244 \\
\hline HydrogenChloride & 18.5275 & 0 & 18.5275 & 18.5275 & 0 & 18.5275 & 18.5275 & 18.5275 & 18.5275 & 18.5275 & 18.5275 & 18.5275 & 18.5275 & 18.5275 \\
\hline Silicon Dioxide & $\begin{array}{l}0 \\
\end{array}$ & 0 & $\begin{array}{l}0 \\
\end{array}$ & 0 & 0 & 0 & 0 & 0 & 0 & 0 & 0 & 0 & 0 & 0 \\
\hline Calcium Oxide & 0 & 0 & 0 & 0 & 0 & 0 & 0 & 0 & 0 & 0 & 0 & 0 & 0 & 0 \\
\hline Benzene & 191.7865 & 0 & 191.7865 & 191.7865 & 0 & 191.7865 & 191.7865 & 191.7865 & 0 & 0 & 0 & 0 & 0 & 0 \\
\hline Naphthalene & 95.8937 & 0 & 95.8937 & 95.8937 & 0 & 95.8937 & 95.8937 & 95.8937 & 0 & 0 & 0 & 0 & 0 & 0 \\
\hline Hybrid Poplar Ch & 0 & 0 & 0 & 0 & 0 & 0 & 0 & 0 & 0 & 0 & 0 & 0 & 0 & 0 \\
\hline Sulfur Dioxide & 0 & 0 & 0 & 0 & 0 & 0 & 0 & 0 & 0 & 0 & 0 & 0 & 0 & 0 \\
\hline Hydrogen Cyanide & 0 & 0 & 0 & 0 & 0 & 0 & 0 & 0 & 0.3646 & 0.3646 & 0.3646 & 0.3646 & 0.3646 & 0.3646 \\
\hline Nitric Oxide & 0 & 0 & \begin{tabular}{l|l}
0 \\
\end{tabular} & \begin{tabular}{l|l}
0 \\
\end{tabular} & 0 & 0 & 0 & 0 & 0 & 0 & 0 & 0 & 0 & 0 \\
\hline Methanol & 0 & 0 & 0 & 0 & 0 & 0 & 0 & 0 & 0.0624 & 0.0624 & 0.0624 & 0.0624 & 0.0624 & 0.0624 \\
\hline Ethanol & 0 & 0 & 0 & 0 & 0 & 0 & 0 & 0 & 0 & 0 & 0 & 0 & 0 & 0 \\
\hline Isopropanol & 0 & 0 & 0 & 0 & 0 & 0 & 0 & 0 & 0 & 0 & 0 & 0 & 0 & 0 \\
\hline N-Propanol & 0 & 0 & 0 & 0 & 0 & 0 & 0 & 0 & 0 & 0 & 0 & 0 & 0 & 0 \\
\hline Isobutanol & 0 & 0 & 0 & 0 & 0 & 0 & 0 & 0 & 0 & 0 & 0 & 0 & 0 & 0 \\
\hline N-Butanol & 0 & 0 & 0 & 0 & 0 & 0 & 0 & 0 & 0 & 0 & 0 & 0 & 0 & 0 \\
\hline 1-Pentanol & 0 & 0 & 0 & $0 \mid$ & 0 & 0 & 0 & 0 & 0 & 0 & 0 & 0 & 0 & 0 \\
\hline
\end{tabular}


Table B.1. (contd)

\begin{tabular}{|c|c|c|c|c|c|c|c|c|c|c|c|c|c|c|}
\hline Stream No. & 450 & 451 & 452 & 453 & 454 & 455 & 471 & 472 & 473 & 474 & 477 & 490 & 491 & 493 \\
\hline Temp F & 110 & 120 & 120 & 58.8714 & 120 & 661.8597 & 240.1355 & 150 & 276.2284 & 150 & 269.3795 & 60 & 124.5558 & 111.1681 \\
\hline Pres psia & 417.5 & 412.5 & 412.5 & 22 & 22 & 440 & 700 & 700 & 1200 & 1200 & 2000 & 14.696 & 20 & 16 \\
\hline Enth MMBtu/h & -426.69 & -194.07 & -232.69 & -232.69 & -50.645 & -48.97 & -186.51 & -192.23 & -184.14 & -192.29 & -184.45 & -0.71369 & 1.939 & -22.189 \\
\hline Vapor mass fraction & 1 & 1 & 0.99164 & 0.9945 & 1 & 1 & 1 & 1 & 1 & 1 & 1 & 1 & 1 & \\
\hline Total lb/h & 182661.719 & \begin{tabular}{|l|}
122595.859 \\
\end{tabular} & 60065.8789 & \begin{tabular}{|l|l|}
60065.8789 \\
\end{tabular} & 13203 & 13203 & 122595.859 & \begin{tabular}{|l|}
122595.859 \\
\end{tabular} & 122595.859 & 122595.859 & 122596 & 170009.438 & \begin{tabular}{|l|}
170009.438 \\
\end{tabular} & 181568.484 \\
\hline Flowrates in $\mathrm{lb} / \mathrm{h}$ & & & & & & & & & & & & & & \\
\hline Oxygen & 0 & 0 & 0 & 0 & 0 & 0 & 0 & 0 & 0 & 0 & 0 & 39597.6523 & 39597.6523 & 39597.6523 \\
\hline Nitrogen & 976.8055 & 976.8055 & 0 & 0 & 0 & 0 & 976.8055 & 976.8055 & 976.8055 & 976.8055 & 976.8058 & 130411.789 & \begin{tabular}{|l|}
130411.789 \\
\end{tabular} & 130839.563 \\
\hline Argon & 0 & 0 & 0 & 0 & 0 & 0 & 0 & 0 & 0 & 0 & 0 & $\begin{array}{r}0 \\
\end{array}$ & 0 & 0 \\
\hline Carbon & 0 & 0 & 0 & 0 & 0 & 0 & 0 & 0 & 0 & 0 & 0 & 0 & 0 & 0 \\
\hline Hydrogen & 8615.5762 & 8615.5762 & 0 & 0 & 0 & 0 & 8615.5762 & 8615.5762 & 8615.5762 & 8615.5762 & 8615.5791 & 0 & 0 & 83.7534 \\
\hline Carbon Monoxide & 100748.828 & \begin{tabular}{|l|}
100748.828 \\
\end{tabular} & 0 & 0 & 0 & 0 & 100748.828 & \begin{tabular}{|l|}
100748.828 \\
\end{tabular} & 100748.828 & 100748.828 & 100748.852 & 0 & 0 & 1189.1895 \\
\hline Carbon Dioxide & 60059.4336 & \begin{tabular}{|l|}
600.5925 \\
\end{tabular} & \begin{tabular}{|l|}
59458.8398 \\
\end{tabular} & 59458.8398 & 13203 & 13203 & 600.5925 & \begin{tabular}{|l|}
600.5925 \\
\end{tabular} & 600.5925 & \begin{tabular}{|r|}
600.5925 \\
\end{tabular} & \begin{tabular}{|l|}
600.5927 \\
\end{tabular} & 0 & 0 & 787.2261 \\
\hline Methane & 11616.4668 & 11616.4668 & 0 & $\begin{array}{r}0 \\
\end{array}$ & 0 & 0 & 11616.4668 & 11616.4668 & 11616.4668 & 11616.4668 & 11616.4717 & 0 & 0 & 7692.0977 \\
\hline Acetylene & 0.0034 & 0.0034 & 0 & 0 & 0 & 0 & 0.0034 & 0.0034 & 0.0034 & 0.0034 & 0.0034 & 0 & 0 & 0.0015 \\
\hline Ethylene & 0.8319 & 0.8319 & 0 & 0 & 0 & 0 & 0.8319 & 0.8319 & 0.8319 & 0.8319 & 0.8319 & 0 & 0 & 0.3643 \\
\hline Ethane & 2.0757 & 2.0757 & 0 & 0 & 0 & 0 & 2.0757 & 2.0757 & 2.0757 & 2.0757 & 2.0757 & 0 & 0 & 272.0825 \\
\hline Propane & 0 & 0 & 0 & 0 & 0 & 0 & 0 & 0 & 0 & 0 & 0 & 0 & 0 & 0 \\
\hline Water & 607.0382 & 0 & 607.0382 & 607.0391 & 0 & 0 & 0 & 0 & 0 & 0 & 0 & 0 & 0 & 56.815 \\
\hline Sulphur & 0 & 0 & 0 & 0 & 0 & 0 & 0 & 0 & 0 & 0 & 0 & 0 & 0 & 0 \\
\hline Carbonyl Sulfide & 0 & 0 & 0 & 0 & 0 & 0 & 0 & 0 & 0 & 0 & 0 & 0 & 0 & 0 \\
\hline Hydrogen Sulfide & 0 & 0 & 0 & 0 & 0 & 0 & 0 & 0 & 0 & 0 & 0 & 0 & 0 & 0 \\
\hline Ammonia & 15.7244 & 15.7244 & 0 & 0 & 0 & 0 & 15.7244 & 15.7244 & 15.7244 & 15.7244 & 15.7244 & 0 & 0 & 6.8868 \\
\hline HydrogenChloride & 18.5275 & 18.5275 & 0 & 0 & 0 & 0 & 18.5275 & 18.5275 & 18.5275 & 18.5275 & 18.5275 & 0 & 0 & 8.1143 \\
\hline Silicon Dioxide & 0 & 0 & 0 & 0 & 0 & 0 & 0 & 0 & 0 & 0 & 0 & 0 & 0 & 0 \\
\hline Calcium Oxide & 0 & 0 & 0 & 0 & 0 & 0 & 0 & 0 & 0 & 0 & 0 & 0 & 0 & 0 \\
\hline Benzene & 0 & 0 & 0 & 0 & 0 & 0 & 0 & 0 & 0 & 0 & 0 & 0 & 0 & 0 \\
\hline Naphthalene & 0 & 0 & 0 & 0 & 0 & 0 & 0 & 0 & 0 & 0 & 0 & 0 & 0 & 0 \\
\hline Hybrid Poplar Ch & 0 & 0 & 0 & 0 & 0 & 0 & 0 & 0 & 0 & 0 & 0 & 0 & 0 & 0 \\
\hline Sulfur Dioxide & 0 & 0 & 0 & 0 & 0 & 0 & 0 & 0 & 0 & 0 & 0 & 0 & 0 & 0 \\
\hline Hydrogen Cyanide & 0.3646 & 0.3646 & 0 & 0 & 0 & 0 & 0.3646 & 0.3646 & 0.3646 & 0.3646 & 0.3646 & 0 & 0 & 0.1597 \\
\hline Nitric Oxide & 0 & 0 & 0 & 0 & 0 & 0 & 0 & 0 & 0 & 0 & 0 & 0 & 0 & 0 \\
\hline Methanol & 0.0624 & 0.0624 & 0 & 0 & 0 & 0 & 0.0624 & 0.0624 & 0.0624 & 0.0624 & 0.0624 & 0 & 0 & 725.4853 \\
\hline Ethanol & 0 & 0 & 0 & 0 & 0 & 0 & 0 & 0 & 0 & 0 & 0 & 0 & 0 & 277.3153 \\
\hline Isopropanol & 0 & 0 & 0 & 0 & 0 & 0 & 0 & 0 & 0 & 0 & 0 & 0 & 0 & 0 \\
\hline N-Propanol & 0 & 0 & 0 & 0 & 0 & 0 & 0 & 0 & 0 & 0 & 0 & 0 & 0 & 23.918 \\
\hline Isobutanol & 0 & 0 & 0 & 0 & 0 & 0 & 0 & 0 & 0 & 0 & 0 & 0 & 0 & 0 \\
\hline N-Butanol & 0 & 0 & 0 & 0 & 0 & 0 & 0 & 0 & 0 & 0 & 0 & 0 & 0 & 5.3214 \\
\hline 1-Pentanol & 0 & 0 & 0 & 0 & 0 & 0 & 0 & 0 & 0 & 0 & 0 & 0 & 0 & 2.5555 \\
\hline
\end{tabular}


Table B.1. (contd)

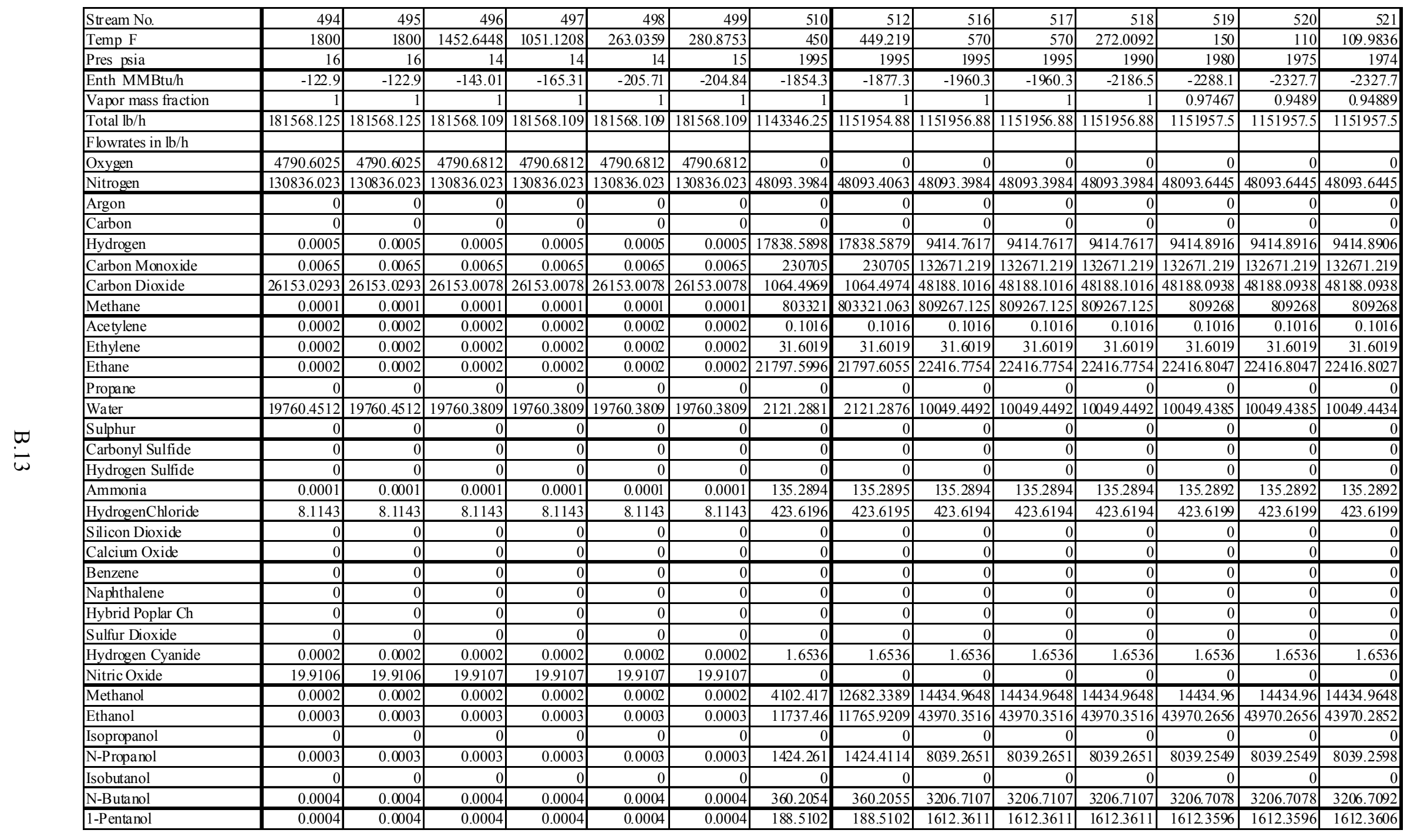


Table B.1 . (contd)

\begin{tabular}{|c|c|c|c|c|c|c|c|c|c|c|c|c|c|c|}
\hline Stream No. & 523 & 524 & 525 & 528 & 530 & 551 & 552 & 553 & 554 & 555 & 556 & 559 & 560 & 561 \\
\hline Temp F & 107.9549 & 107.9549 & 110.8222 & 110.8216 & 110.8216 & 107.9549 & 107.9549 & 230 & 49.7944 & 130 & 132.2388 & 141.7071 & 189.1983 & 550 \\
\hline \begin{tabular}{|l|} 
Pres psia \\
\end{tabular} & 1974 & 1974 & 35 & 35 & 35 & 1974 & 1974 & 1974 & 22 & 1974 & 2000 & 2000 & 2000 & 1995 \\
\hline Enth MMBtuh & -2130.7 & -197.02 & -197.02 & -189.94 & -7.0817 & -42.613 & -2088 & -176.83 & -176.83 & -1897.2 & -1896.1 & -2080.5 & -27.085 & -22.971 \\
\hline Vapor mass fraction & & 0 & 0.044242 & & & & & & & & & & 0 & \\
\hline Total lb/h & 1088448.88 & \begin{tabular}{|l|}
63508.6484 \\
\end{tabular} & 63508.6484 & 60698.9102 & 2809.7424 & 21768.9746 & 1066679.88 & 45926.8711 & 45926.8711 & 1020752.75 & 1020753 & 1143346.25 & 8608.5234 & 8608.5234 \\
\hline Flowrates in $\mathrm{lb} / \mathrm{h}$ & & & & & & & & & & & & & & \\
\hline Oxygen & 0 & 0 & 0 & 0 & 0 & & 0 & 0 & $\underline{0}$ & 0 & 0 & 0 & 0 & 0 \\
\hline Nitrogen & 48078.5508 & 15.0906 & 15.0906 & 0.0344 & 15.0562 & 961.571 & 47117 & 0 & 0 & 47117 & 47117 & 48093.3984 & 0 & 0 \\
\hline Argon & 0 & $\begin{array}{r}0 \\
0\end{array}$ & 0 & 0 & 0 & 0 & 0 & 0 & 0 & 0 & 0 & 0 & 0 & 0 \\
\hline \begin{tabular}{|l|} 
Carbon \\
\end{tabular} & & 0 & 0 & 0 & 0 & 0 & 0 & 0 & 0 & 0 & 0 & 0 & 0 & 0 \\
\hline Hydrogen & 9411.9102 & 2.9797 & 2.9797 & 0.0063 & 2.9734 & 188.2382 & 9223.6719 & 0 & 0 & 9223.6699 & 9223.6719 & 17838.5898 & 0 & 0 \\
\hline Carbon Monoxide & 132608.375 & \begin{tabular}{|l|}
62.8775 \\
\end{tabular} & 62.8775 & 0.2336 & 62.6439 & 2652.1672 & 129956.195 & 0 & 0 & \begin{tabular}{|l|}
129956.117 \\
\end{tabular} & \begin{tabular}{|l|}
129956.211 \\
\end{tabular} & 230705 & 0 & $\underline{0}$ \\
\hline Carbon Dioxide & 47337.5273 & \begin{tabular}{|l|}
850.5696 \\
\end{tabular} & 850.5696 & 169.2234 & 681.3462 & 994.7506 & 46390.7773 & 45926.8711 & 45926.8711 & \begin{tabular}{|l|}
463.9044 \\
\end{tabular} & \begin{tabular}{|l|l|}
463.9045 \\
\end{tabular} & $\begin{array}{l}1064.4969 \\
\end{array}$ & 0 & 0 \\
\hline Methane & 807863 & 1404.6102 & 1404.6102 & 23.9136 & 1380.6965 & 16157.2578 & 791706 & 0 & 0 & 791706 & 791706 & 803321 & 0 & 0 \\
\hline Acetylene & 0.1002 & 0.0014 & 0.0014 & 0.0002 & 0.0011 & 0.002 & 0.0982 & 0 & $\overline{0}$ & 0.0982 & 0.0982 & 0.1016 & 0 & 0 \\
\hline Ethylene & 31.3981 & $\begin{array}{r}0.2039 \\
\end{array}$ & 0.2039 & 0.017 & 0.1869 & 0.628 & 30.7701 & 0 & 0 & 30.7701 & \begin{tabular}{|l|}
30.7701 \\
\end{tabular} & 31.6019 & 0 & 0 \\
\hline \begin{tabular}{|l|} 
Ethane \\
\end{tabular} & 22240.418 & 176.3845 & 176.3845 & 19.2415 & 157.1431 & 444.8083 & 21795.6113 & 0 & 0 & \begin{tabular}{|l|}
21795.6016 \\
\end{tabular} & 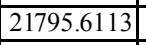 & 21797.5996 & 0 & 0 \\
\hline Propane & & & 0 & 0 & 0 & 0 & & 0 & 0 & \begin{tabular}{|r|}
0 \\
\end{tabular} & $\begin{array}{r}0 \\
\end{array}$ & 0 & 0 & 0 \\
\hline Water & 2164.5823 & 7884.8535 & 7884.853 & 7804.6665 & 80.1865 & 43.2916 & 2121.2908 & 0 & 0 & 2121.2913 & 2121.2915 & 2121.2881 & 0 & 0 \\
\hline \begin{tabular}{|l|} 
Sulphur \\
\end{tabular} & & & 0 & & 0 & 0 & & 0 & 0 & 0 & 0 & 0 & 0 & 0 \\
\hline Carbonyl Sulfide & 0 & 0 & $\overline{0}$ & 0 & 0 & 0 & $\overline{0}$ & 0 & $\overline{0}$ & 0 & 0 & 0 & 0 & \\
\hline Hydrogen Sulfide & & 0 & 0 & 0 & 0 & 0 & & 0 & 0 & 0 & 0 & 0 & 0 & 0 \\
\hline \begin{tabular}{|l|} 
Ammonia \\
\end{tabular} & 122.006 & 13.2833 & 13.2833 & 8.6993 & $\begin{array}{l}4.584 \\
\end{array}$ & 2.4401 & 119.5659 & 0 & 0 & 119.5659 & 119.5659 & 135.2894 & 0 & 0 \\
\hline HydrogenChloride & 413.3613 & 10.2586 & 10.2586 & 2.7101 & 7.5485 & 8.2672 & 405.0941 & 0 & $\underline{0}$ & $\begin{array}{l}405.094 \\
\end{array}$ & 405.0941 & 423.6196 & 0 & \\
\hline Silicon Dioxide & & & 0 & 0 & 0 & 0 & & 0 & 0 & 0 & & 0 & 0 & 0 \\
\hline \begin{tabular}{|l} 
Calcium Oxide \\
\end{tabular} & 0 & 0 & 0 & 0 & 0 & & 0 & 0 & 0 & 0 & & 0 & 0 & 0 \\
\hline Benzene & 0 & 0 & 0 & 0 & 0 & 0 & 0 & 0 & 0 & 0 & 0 & 0 & 0 & \\
\hline Naphthalene & 0 & 0 & 0 & 0 & 0 & 0 & 0 & 0 & 0 & 0 & 0 & 0 & 0 & \\
\hline Hybrid Poplar Ch & 0 & 0 & 0 & 0 & 0 & 0 & 0 & 0 & $\underline{0}$ & 0 & 0 & 0 & 0 & 0 \\
\hline Sulfur Dioxide & & 0 & 0 & & 0 & & 0 & 0 & $\underline{0}$ & & 0 & 0 & 0 & 0 \\
\hline Hydrogen Cyanide & 1.3153 & 0.3383 & 0.3383 & 0.3012 & 0.0371 & 0.0263 & 1.289 & 0 & 0 & 1.289 & 1.289 & 1.6536 & 0 & 0 \\
\hline Nitric Oxide & & & 0 & & 0 & & & 0 & 0 & 0 & 0 & 0 & 0 & \\
\hline Methanol & 44186.0835 & \begin{tabular}{|l|}
10248.8721 \\
\end{tabular} & 10248.8721 & 10136.3818 & 112.4901 & \begin{tabular}{|l|l|}
83.7217 \\
\end{tabular} & 4102.3623 & 0 & $\overline{0}$ & \begin{tabular}{|l|l|}
4102.3608 \\
\end{tabular} & 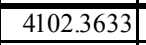 & 4102.417 & 8579.918 & 8579.918 \\
\hline Ethanol & 11977.0039 & \begin{tabular}{|l|}
31993.25 \\
\end{tabular} & 31993.25 & 31720.709 & 272.5431 & 239.5401 & 11737.4639 & 0 & $\underline{0}$ & \begin{tabular}{|l|l|}
11737.4512 \\
\end{tabular} & \begin{tabular}{|l|l|l|l|l|l|}
117378 \\
\end{tabular} & 11737.46 & 28.455 & 28.455 \\
\hline Isopropanol & 0 & 0 & 0 & & 0 & 0 & & 0 & 0 & $\begin{array}{r}0 \\
\end{array}$ & 0 & 0 & 0 & 0 \\
\hline N-Propanol & 1453.3259 & 6585.9272 & 6585.9268 & 6560.4063 & 25.5206 & 29.0665 & 1424.2594 & 0 & 0 & 1424.2593 & 1424.2595 & 1424.261 & 0.1499 & 0.1499 \\
\hline Isobutanol & & & 0 & & 0 & & & 0 & $\underline{0}$ & 0 & 0 & & 0 & 0 \\
\hline N-Butanol & 367.5562 & \begin{tabular}{|l|}
2839.1504 \\
\end{tabular} & 2839.1501 & 2834.3521 & 4.7981 & 7.3511 & 360.2051 & 0 & 0 & 360.205 & 360.2051 & 360.2054 & 0 & 0 \\
\hline 1-Pentanol & 192.3572 & \begin{tabular}{|l|}
1420.002 \\
\end{tabular} & 1420.0017 & 1418.0146 & 1.9873 & \begin{tabular}{|l|l|}
3.8471 \\
\end{tabular} & 188.5101 & 0 & $\overline{0}$ & 188.51 & 188.5101 & 188.5102 & 0 & $\overline{0}$ \\
\hline
\end{tabular}


Table B.1. (contd)

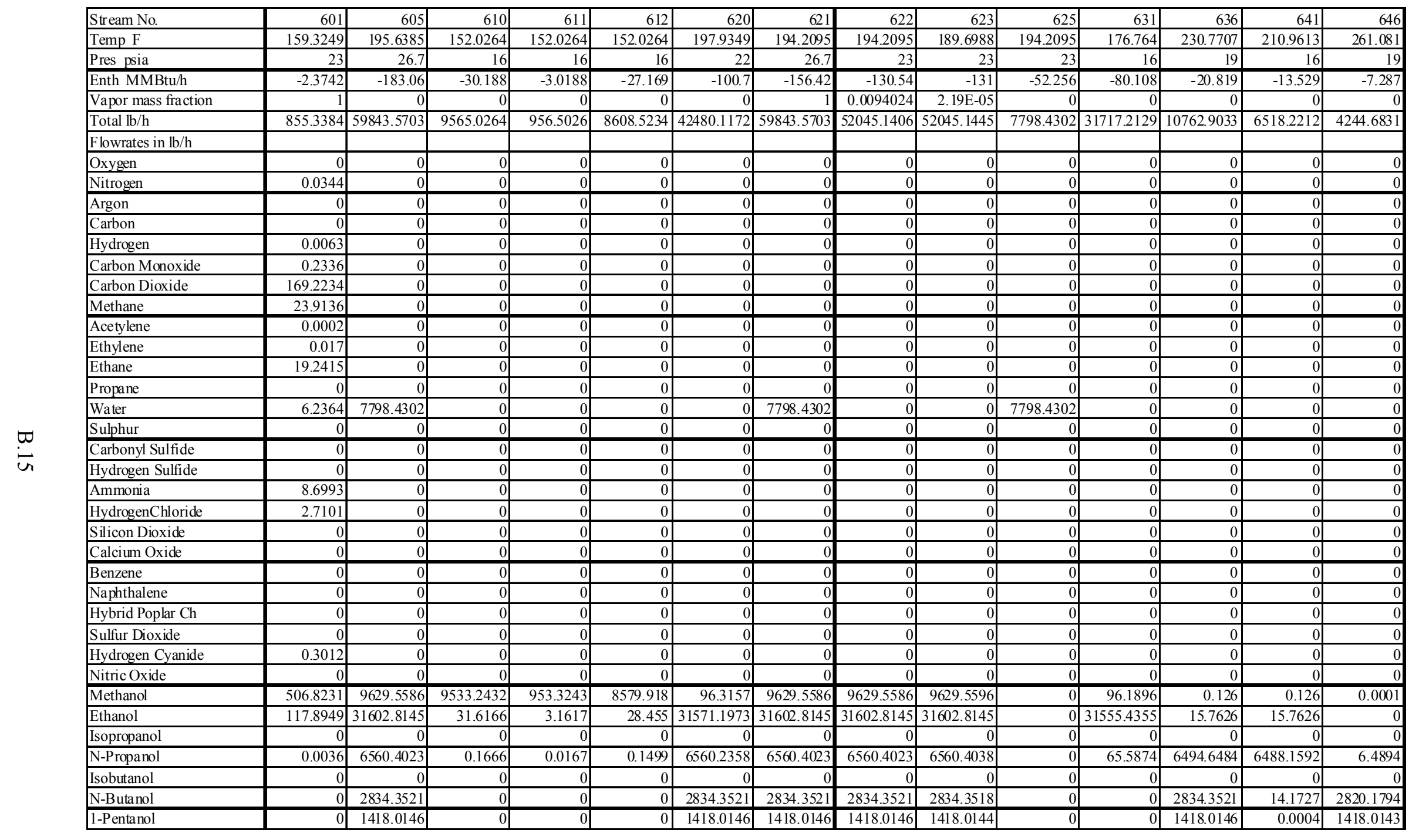


Table B.1. (contd)

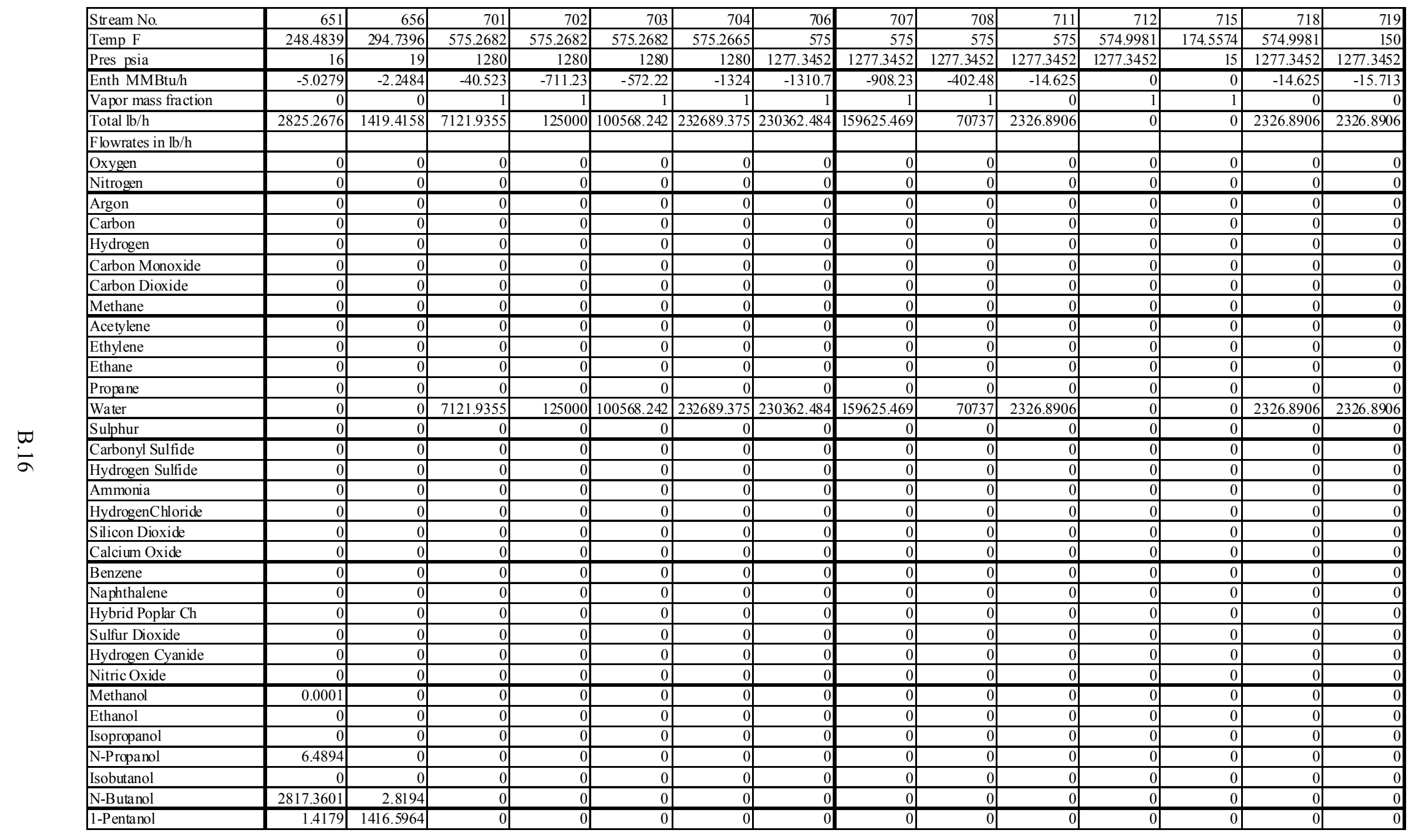


Table B.1. (contd)

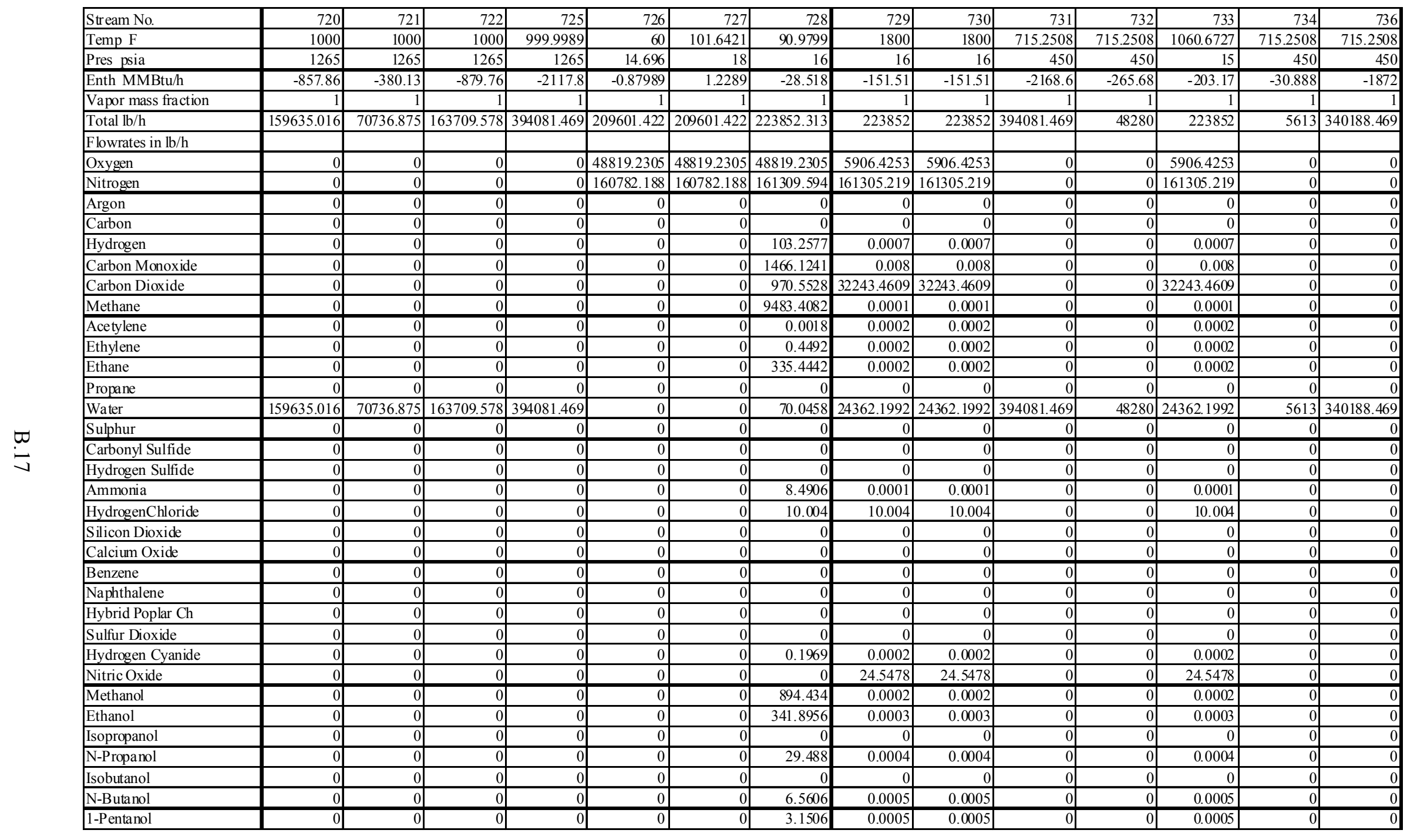


Table B.1. (contd)

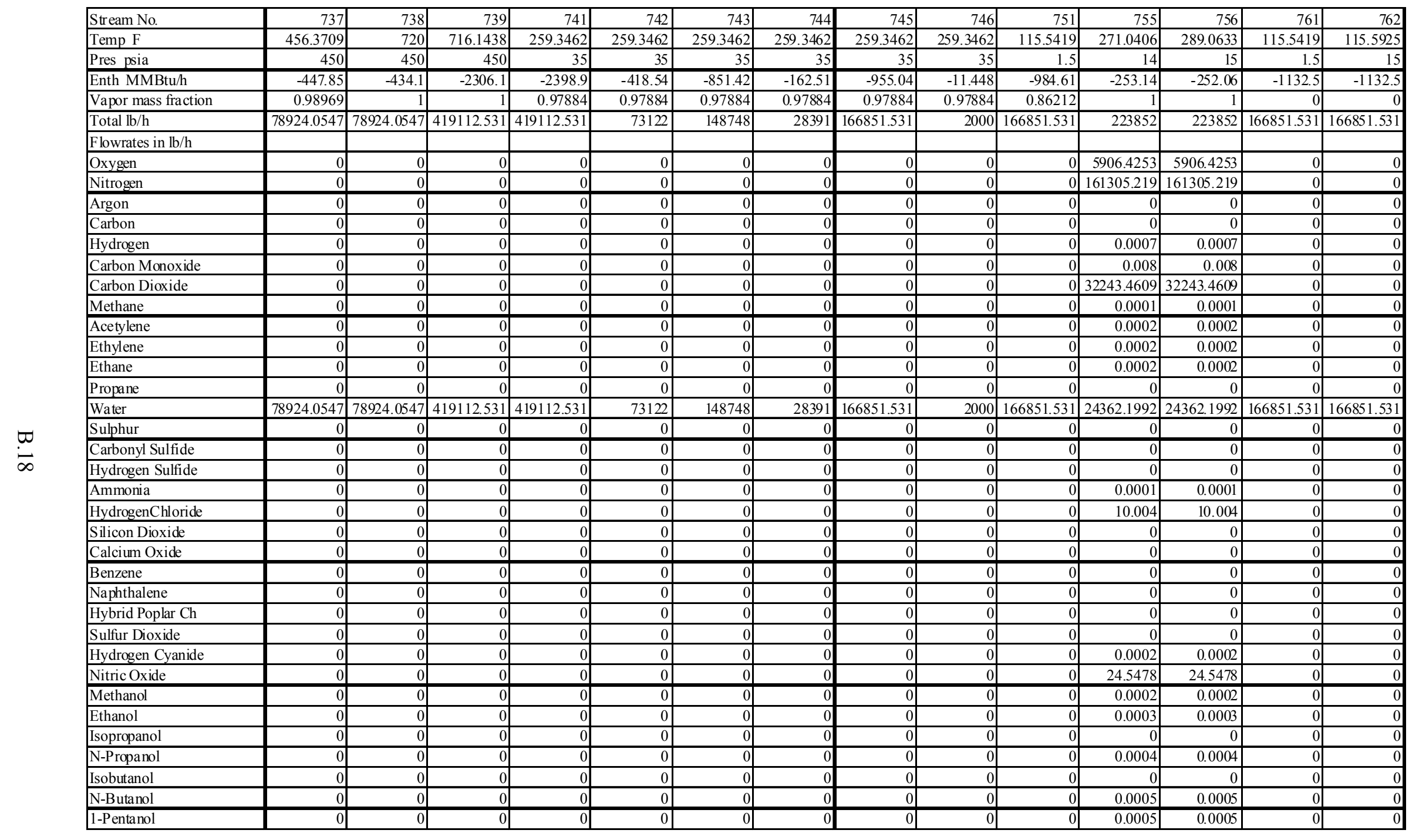


Table B.1. (contd)

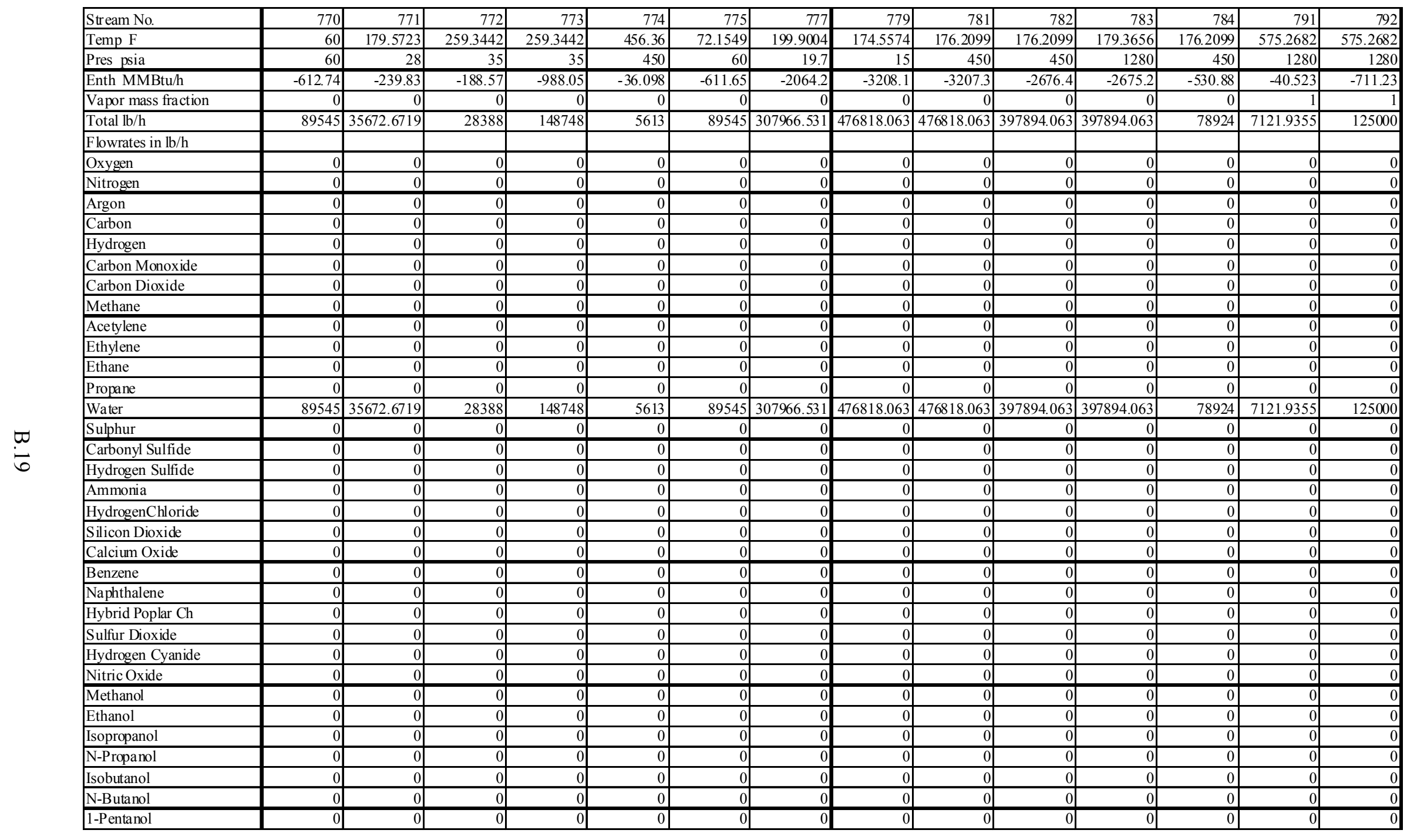


Table B.1. (contd)

\begin{tabular}{|c|c|c|c|c|c|c|c|c|c|c|c|c|c|c|}
\hline Stream No. & 794 & 795 & 796 & 797 & 798 & 1602 & 1603 & 1604 & 1605 & 1701 & 1702 & 1703 & 1741 & 1742 \\
\hline Temp F & 1000 & 575.2682 & 1000 & 179.5723 & 720 & 41.2403 & 41.2403 & 41.2403 & 41.2403 & 140 & 140 & 140 & 277.9421 & 181.6632 \\
\hline Pres psia & 1265 & 1280 & 1265 & 28 & 450 & 16 & 16 & 16 & 16 & 15 & 15 & 15 & 28 & 54 \\
\hline Enth MMBtu/h & -857.86 & -572.22 & -380.13 & -239.83 & -434.1 & -55.088 & -1.2119 & -29.747 & -24.128 & -58607 & -586.06 & -58020 & 0 & -70.851 \\
\hline Vapor mass fraction & 1 & 1 & 1 & 0 & 1 & 0.97147 & 0.97147 & 0.97147 & 0.97147 & 0 & 0 & 0 & 0 & 0 \\
\hline Total lb/h & 159635.016 & \begin{tabular}{|l|}
100568.242 \\
\end{tabular} & 70736.875 & \begin{tabular}{|l|}
35672.6719 \\
\end{tabular} & 78924.0547 & 26390.5586 & 580.5922 & \begin{tabular}{|l|}
14250.9014 \\
\end{tabular} & 11559.0654 & 8690904 & \begin{tabular}{|l|}
86908.8203 \\
\end{tabular} & 8603973 & 0 & 10541.7666 \\
\hline Flowrates in $\mathrm{lb} / \mathrm{h}$ & & & & & & & & & & & & & & \\
\hline Oxygen & 0 & 0 & 0 & 0 & 0 & 0 & 0 & 0 & 0 & 0 & 0 & 0 & 0 & 0 \\
\hline Nitrogen & 0 & 0 & 0 & 0 & 0 & 976.6617 & 21.4866 & 527.3973 & 427.7778 & 0.2494 & 0.0025 & 0.2469 & 0 & 0 \\
\hline Argon & 0 & 0 & 0 & 0 & 0 & 0 & 0 & 0 & 0 & 0 & 0 & 0 & 0 & 0 \\
\hline Carbon & 0 & 0 & 0 & 0 & 0 & 0 & 0 & 0 & 0 & 0 & 0 & 0 & 0 & 0 \\
\hline Hydrogen & 0 & 0 & 0 & 0 & 0 & 191.2179 & 4.2068 & 103.2577 & 83.7534 & 3.0927 & 0.0309 & 3.0617 & 0 & 0 \\
\hline Carbon Monoxide & 0 & 0 & 0 & 0 & 0 & 2715.0447 & 59.731 & 1466.1241 & 1189.1895 & 45.3898 & 0.4539 & 44.936 & 0 & 0 \\
\hline Carbon Dioxide & 0 & 0 & 0 & 0 & 0 & 1797.3199 & 39.541 & 970.5528 & 787.2261 & 30858.6641 & 308.5646 & 30547.8984 & 0 & 0 \\
\hline Methane & 0 & 0 & 0 & 0 & 0 & 17561.8672 & 386.3611 & 9483.4082 & 7692.0977 & 9.7011 & 0.097 & 9.6041 & 0 & 0 \\
\hline Acetylene & 0 & 0 & 0 & 0 & 0 & 0.0034 & 0.0001 & 0.0018 & 0.0015 & 0.3578 & 0.0036 & 0.3542 & 0 & 0 \\
\hline Ethylene & 0 & 0 & 0 & 0 & 0 & 0.8318 & 0.0183 & 0.4492 & 0.3643 & 9.3461 & 0.0935 & 9.2526 & 0 & 0 \\
\hline Ethane & 0 & 0 & 0 & 0 & 0 & 621.1929 & 13.6662 & 335.4442 & 272.0825 & 0.0417 & 0.0004 & 0.0413 & 0 & 0 \\
\hline Propane & 0 & 0 & 0 & 0 & 0 & 0 & 0 & 0 & 0 & 0 & 0 & 0 & 0 & 0 \\
\hline Water & 159635.016 & 100568.242 & 70736.875 & \begin{tabular}{|l|}
35672.6719 \\
\end{tabular} & 78924.0547 & 129.7145 & 2.8537 & 70.0458 & 56.815 & 8644681 & 86446.6406 & 8558217 & 0 & 10541.7666 \\
\hline Sulphur & 0 & $\begin{array}{r}0 \\
\end{array}$ & 0 & 0 & 0 & 0 & 0 & 0 & 0 & 0 & 0 & 0 & 0 & 0 \\
\hline Carbonyl Sulfide & 0 & 0 & 0 & 0 & 0 & 0 & 0 & 0 & 0 & 0 & 0 & 0 & 0 & 0 \\
\hline Hydrogen Sulfide & 0 & 0 & 0 & 0 & 0 & 0 & 0 & 0 & 0 & 45.1209 & 0.4512 & 44.668 & 0 & 0 \\
\hline Ammonia & 0 & 0 & 0 & 0 & 0 & 15.7234 & 0.3459 & 8.4906 & 6.8868 & 15250.8525 & 152.4876 & 15096.2705 & 0 & 0 \\
\hline HydrogenChloride & 0 & 0 & 0 & 0 & 0 & 18.5259 & 0.4076 & 10.004 & 8.1143 & 0.2041 & 0.002 & 0.2021 & 0 & 0 \\
\hline Silicon Dioxide & 0 & 0 & 0 & 0 & 0 & 0 & 0 & 0 & 0 & 0 & 0 & 0 & 0 & 0 \\
\hline Calcium Oxide & 0 & 0 & 0 & 0 & 0 & 0 & 0 & 0 & 0 & 0 & 0 & 0 & 0 & 0 \\
\hline Benzene & 0 & 0 & 0 & 0 & 0 & 0 & 0 & 0 & 0 & 0.3661 & 0.0037 & 0.3624 & 0 & 0 \\
\hline Naphthalene & 0 & 0 & 0 & 0 & 0 & 0 & 0 & 0 & 0 & 0.1413 & 0.0014 & 0.1399 & 0 & 0 \\
\hline Hybrid Poplar Ch & 0 & 0 & 0 & 0 & 0 & 0 & 0 & 0 & 0 & 0 & 0 & 0 & 0 & 0 \\
\hline Sulfur Dioxide & 0 & 0 & 0 & 0 & 0 & 0 & 0 & 0 & 0 & 0 & 0 & 0 & 0 & 0 \\
\hline Hydrogen Cyanide & 0 & 0 & 0 & 0 & 0 & 0.3646 & 0.008 & 0.1969 & 0.1597 & 0 & 0 & 0 & 0 & 0 \\
\hline Nitric Oxide & 0 & 0 & 0 & 0 & 0 & 0 & 0 & 0 & 0 & 0 & 0 & 0 & 0 & 0 \\
\hline Methanol & 0 & 0 & 0 & 0 & 0 & 1656.3593 & 36.4399 & 894.434 & 725.4853 & 0 & 0 & 0 & 0 & 0 \\
\hline Ethanol & 0 & 0 & 0 & 0 & 0 & 633.14 & 13.9291 & 341.8956 & 277.3153 & 0 & 0 & 0 & 0 & 0 \\
\hline Isopropanol & 0 & 0 & 0 & 0 & 0 & 0 & 0 & 0 & 0 & 0 & 0 & 0 & 0 & 0 \\
\hline N-Propanol & 0 & 0 & 0 & 0 & 0 & 54.6074 & 1.2014 & 29.488 & 23.918 & 0 & 0 & 0 & 0 & 0 \\
\hline Isobutanol & 0 & 0 & 0 & 0 & 0 & 0 & 0 & 0 & 0 & 0 & 0 & 0 & 0 & 0 \\
\hline N-Butanol & 0 & 0 & 0 & 0 & 0 & 12.1492 & 0.2673 & 6.5606 & 5.3214 & 0 & 0 & 0 & 0 & 0 \\
\hline 1-Pentanol & 0 & 0 & 0 & 0 & 0 & 5.8345 & 0.1284 & 3.1506 & 2.5555 & 0 & 0 & 0 & 0 & 0 \\
\hline
\end{tabular}


Table B.1. (contd)

\begin{tabular}{|c|c|c|c|c|c|c|c|c|c|c|c|c|c|c|}
\hline Stream No. & 1743 & 1744 & 1745 & 1746 & 1747 & 1748 & 1749 & 1750 & 1751 & 1830 & 1831 & 1834 & 1835 & 1840 \\
\hline Temp F & 181.6632 & 195.5736 & 188.2532 & 209.1053 & 192.9911 & 231.225 & 196.6364 & 179.5723 & 110 & 90 & 110 & 90 & 110 & 90 \\
\hline Pres psia & 28 & 109.5 & 28 & 220 & 28 & 465 & 28 & 28 & 417.5 & 60 & 60 & 60 & 60 & 65 \\
\hline Enth MMBtu/h & -70.851 & -63.596 & -134.45 & -39.358 & -173.8 & -18.155 & -191.96 & -239.83 & -247.66 & -83888 & -83641 & -569.06 & -567.4 & -931.27 \\
\hline Vapor mass fraction & 0 & 0 & 0 & 0 & 0 & 0 & 0 & 0 & 0 & 0 & 0 & 0 & 0 & 0 \\
\hline Total lb/h & 10541.7666 & 9482.0117 & 20023.7773 & 5880.0854 & 25903.8633 & 2721.4614 & 28625.3242 & 35672.6719 & 36458.7539 & 12313236 & 12313236 & 83529.2891 & \begin{tabular}{|l|}
83529.2891 \\
\end{tabular} & 136694 \\
\hline \multicolumn{15}{|l|}{ Flowrates in $\mathrm{lb} / \mathrm{h}$} \\
\hline Oxygen & 0 & 0 & 0 & 0 & 0 & 0 & 0 & 0 & 0 & 0 & 0 & 0 & 0 & 0 \\
\hline Nitrogen & 0 & 0 & 0 & 0 & 0 & 0 & 0 & 0 & 0 & 0 & 0 & 0 & 0 & 0 \\
\hline Argon & 0 & 0 & 0 & 0 & 0 & 0 & 0 & 0 & 0 & 0 & 0 & 0 & 0 & 0 \\
\hline Carbon & 0 & $\overline{0}$ & 0 & 0 & 0 & 0 & 0 & 0 & 0 & 0 & 0 & 0 & 0 & 0 \\
\hline Hydrogen & 0 & 0 & 0 & 0 & 0 & 0 & 0 & 0 & 0 & 0 & 0 & 0 & 0 & 0 \\
\hline Carbon Monoxide & 0 & 0 & 0 & 0 & 0 & 0 & 0 & 0 & 0 & 0 & 0 & 0 & 0 & 0 \\
\hline Carbon Dioxide & 0 & 0 & 0 & 0 & 0 & 0 & 0 & 0 & 0 & 0 & 0 & 0 & 0 & 0 \\
\hline Methane & 0 & 0 & 0 & 0 & 0 & 0 & 0 & 0 & 0 & 0 & 0 & 0 & 0 & 0 \\
\hline Acetylene & 0 & 0 & 0 & 0 & 0 & 0 & 0 & 0 & 0 & 0 & 0 & 0 & 0 & 0 \\
\hline Ethylene & 0 & 0 & 0 & 0 & 0 & 0 & 0 & 0 & 0 & 0 & 0 & 0 & 0 & 0 \\
\hline Ethane & 0 & 0 & 0 & 0 & 0 & 0 & 0 & 0 & 0 & 0 & 0 & 0 & 0 & 0 \\
\hline Propane & 0 & 0 & 0 & 0 & 0 & 0 & 0 & 0 & 0 & 0 & 0 & 0 & 0 & 0 \\
\hline Water & 10541.7666 & 9482.0117 & 20023.7773 & 5880.0854 & 25903.8633 & 2721.4614 & 28625.3242 & 35672.6719 & 36458.7539 & 12313236 & 12313236 & 83529.2891 & \begin{tabular}{|l|}
83529.2891 \\
\end{tabular} & 136694 \\
\hline Sulphur & 0 & 0 & 0 & 0 & 0 & 0 & 0 & 0 & 0 & 0 & 0 & 0 & $\begin{array}{r}0 \\
\end{array}$ & 0 \\
\hline Carbonyl Sulfide & 0 & 0 & 0 & 0 & 0 & 0 & 0 & 0 & 0 & 0 & 0 & 0 & 0 & 0 \\
\hline Hydrogen Sulfide & 0 & 0 & 0 & 0 & 0 & 0 & 0 & 0 & 0 & 0 & 0 & 0 & 0 & 0 \\
\hline Ammonia & 0 & 0 & 0 & 0 & 0 & 0 & 0 & 0 & 0 & 0 & 0 & 0 & 0 & 0 \\
\hline HydrogenChloride & 0 & 0 & 0 & 0 & 0 & 0 & 0 & 0 & 0 & 0 & 0 & 0 & 0 & 0 \\
\hline Silicon Dioxide & 0 & 0 & 0 & 0 & 0 & 0 & 0 & 0 & 0 & 0 & 0 & 0 & 0 & 0 \\
\hline Calcium Oxide & 0 & 0 & 0 & 0 & 0 & 0 & 0 & 0 & 0 & 0 & 0 & 0 & 0 & 0 \\
\hline Benzene & 0 & 0 & 0 & 0 & 0 & 0 & 0 & 0 & 0 & 0 & 0 & 0 & 0 & 0 \\
\hline Naphthalene & 0 & 0 & 0 & 0 & 0 & 0 & 0 & 0 & 0 & 0 & 0 & 0 & 0 & 0 \\
\hline Hybrid Poplar Ch & 0 & 0 & 0 & 0 & 0 & 0 & 0 & 0 & 0 & 0 & 0 & 0 & 0 & 0 \\
\hline Sulfur Dioxide & 0 & 0 & 0 & 0 & 0 & 0 & 0 & 0 & 0 & 0 & 0 & 0 & 0 & 0 \\
\hline Hydrogen Cyanide & 0 & 0 & 0 & 0 & 0 & 0 & 0 & 0 & 0 & 0 & 0 & 0 & 0 & 0 \\
\hline Nitric Oxide & 0 & 0 & 0 & 0 & 0 & 0 & 0 & 0 & 0 & 0 & 0 & 0 & 0 & 0 \\
\hline Methanol & 0 & 0 & 0 & 0 & 0 & 0 & 0 & 0 & 0 & 0 & 0 & 0 & 0 & 0 \\
\hline Ethanol & 0 & 0 & 0 & 0 & 0 & 0 & 0 & 0 & 0 & 0 & 0 & 0 & 0 & 0 \\
\hline Isopropanol & 0 & 0 & 0 & 0 & 0 & 0 & 0 & 0 & 0 & 0 & 0 & 0 & 0 & 0 \\
\hline N-Propanol & 0 & 0 & 0 & 0 & 0 & 0 & 0 & 0 & 0 & 0 & 0 & 0 & 0 & 0 \\
\hline Isobutanol & 0 & 0 & 0 & 0 & 0 & 0 & 0 & 0 & 0 & 0 & 0 & 0 & 0 & 0 \\
\hline N-Butanol & 0 & 0 & 0 & 0 & 0 & 0 & 0 & 0 & 0 & 0 & 0 & 0 & 0 & 0 \\
\hline 1-Pentanol & 0 & 0 & 0 & 0 & 0 & 0 & 0 & 0 & 0 & 0 & 0 & 0 & 0 & 0 \\
\hline
\end{tabular}


Table B.1. (contd)

\begin{tabular}{|c|c|c|c|c|c|c|c|c|c|c|c|c|c|c|}
\hline Stream No. & 1841 & 1842 & 1843 & 1850 & 1851 & 1861 & 1862 & 1871 & 1872 & 1910 & 1931 & 1932 & 1935 & 1936 \\
\hline Temp F & 110 & 90 & 110 & 90 & 110 & 90 & 110 & 90 & 110 & 259.3482 & 179 & 575.2682 & 179 & 400 \\
\hline Pres psia & 65 & 65 & 65 & 65 & 60 & 60 & 60 & 65 & 65 & 35 & 1280 & 1280 & 1280 & 1280 \\
\hline Enth MMBtu/h & -928.54 & -1919.8 & -1914.2 & -13479 & -13439 & -155.23 & -154.77 & -50368 & -50220 & -417.08 & -47.886 & -40.523 & -840.46 & -811.81 \\
\hline Vapor mass fraction & 0 & 0 & 0 & 0 & 0 & 0 & 0 & 0 & 0 & 1 & 0 & 1 & 0 & 0 \\
\hline Total lb/h & 136694 & 281794 & 281794 & \begin{tabular}{|l|}
1978409.88 \\
\end{tabular} & 1978409.88 & \begin{tabular}{|l|}
22784.5566 \\
\end{tabular} & 22784.5566 & 7393089.5 & 7393089.5 & 73120.0938 & 7121.9355 & 7121.9355 & 125000 & 125000 \\
\hline \multicolumn{15}{|l|}{ Flowrates in $\mathrm{lb} / \mathrm{h}$} \\
\hline Oxygen & 0 & 0 & 0 & 0 & 0 & 0 & 0 & 0 & 0 & 0 & 0 & 0 & 0 & 0 \\
\hline Nitrogen & 0 & 0 & 0 & 0 & 0 & 0 & 0 & 0 & 0 & 0 & 0 & 0 & 0 & 0 \\
\hline Argon & 0 & 0 & 0 & 0 & 0 & 0 & 0 & 0 & 0 & 0 & 0 & 0 & 0 & 0 \\
\hline Carbon & 0 & 0 & 0 & 0 & 0 & 0 & 0 & 0 & 0 & 0 & 0 & 0 & 0 & 0 \\
\hline Hydrogen & 0 & 0 & 0 & 0 & 0 & 0 & 0 & 0 & 0 & 0 & 0 & 0 & 0 & 0 \\
\hline Carbon Monoxide & 0 & 0 & 0 & 0 & 0 & 0 & 0 & 0 & 0 & 0 & 0 & 0 & 0 & 0 \\
\hline Carbon Dioxide & 0 & 0 & 0 & 0 & 0 & 0 & 0 & 0 & 0 & 0 & 0 & 0 & 0 & 0 \\
\hline Methane & 0 & 0 & 0 & 0 & 0 & 0 & 0 & 0 & 0 & 0 & 0 & 0 & 0 & 0 \\
\hline Acetylene & 0 & 0 & 0 & 0 & 0 & 0 & 0 & 0 & 0 & 0 & 0 & 0 & 0 & 0 \\
\hline Ethylene & 0 & 0 & 0 & 0 & 0 & 0 & 0 & 0 & 0 & 0 & 0 & 0 & 0 & 0 \\
\hline Ethane & 0 & 0 & 0 & 0 & 0 & 0 & 0 & 0 & 0 & 0 & 0 & 0 & 0 & 0 \\
\hline Propane & 0 & 0 & 0 & 0 & 0 & 0 & 0 & 0 & 0 & 0 & 0 & 0 & 0 & 0 \\
\hline Water & 136694 & 281794 & 281794 & \begin{tabular}{|l|}
1978409.88 \\
\end{tabular} & 1978409.88 & 22784.5566 & 22784.5566 & 7393089.5 & 7393089.5 & 73120.0938 & 7121.9355 & 7121.9355 & 125000 & 125000 \\
\hline Sulphur & 0 & 0 & 0 & $\begin{array}{r}0 \\
\end{array}$ & 0 & 0 & $\begin{array}{r}0 \\
\end{array}$ & 0 & 0 & 0 & 0 & 0 & 0 & 0 \\
\hline Carbonyl Sulfide & 0 & 0 & 0 & 0 & 0 & 0 & 0 & 0 & 0 & 0 & 0 & 0 & 0 & 0 \\
\hline Hydrogen Sulfide & 0 & 0 & 0 & 0 & 0 & 0 & 0 & 0 & 0 & 0 & 0 & 0 & 0 & 0 \\
\hline Ammonia & 0 & 0 & 0 & 0 & 0 & 0 & 0 & 0 & 0 & 0 & 0 & 0 & 0 & 0 \\
\hline HydrogenChloride & 0 & 0 & 0 & 0 & 0 & 0 & 0 & 0 & 0 & 0 & 0 & 0 & 0 & 0 \\
\hline Silicon Dioxide & 0 & 0 & 0 & 0 & 0 & 0 & 0 & 0 & 0 & 0 & 0 & 0 & 0 & 0 \\
\hline Calcium Oxide & 0 & 0 & 0 & 0 & 0 & 0 & 0 & 0 & 0 & 0 & 0 & 0 & 0 & 0 \\
\hline Benzene & 0 & 0 & 0 & 0 & 0 & 0 & 0 & 0 & 0 & 0 & 0 & 0 & 0 & 0 \\
\hline Naphthalene & 0 & 0 & 0 & 0 & 0 & 0 & 0 & 0 & 0 & 0 & 0 & 0 & 0 & 0 \\
\hline Hybrid Poplar Ch & 0 & 0 & 0 & 0 & 0 & 0 & 0 & 0 & 0 & 0 & 0 & 0 & 0 & 0 \\
\hline Sulfur Dioxide & 0 & 0 & 0 & 0 & 0 & 0 & 0 & 0 & 0 & 0 & 0 & 0 & 0 & 0 \\
\hline Hydrogen Cyanide & 0 & 0 & 0 & 0 & 0 & 0 & 0 & 0 & 0 & 0 & 0 & 0 & 0 & 0 \\
\hline Nitric Oxide & 0 & 0 & 0 & 0 & 0 & 0 & 0 & 0 & 0 & 0 & 0 & 0 & 0 & 0 \\
\hline Methanol & 0 & 0 & 0 & 0 & 0 & 0 & 0 & 0 & 0 & 0 & 0 & 0 & 0 & 0 \\
\hline Ethanol & 0 & 0 & 0 & 0 & 0 & 0 & 0 & 0 & 0 & 0 & 0 & 0 & 0 & 0 \\
\hline Isopropanol & 0 & 0 & 0 & 0 & 0 & 0 & 0 & 0 & 0 & 0 & 0 & 0 & 0 & 0 \\
\hline N-Propanol & 0 & 0 & 0 & 0 & 0 & 0 & 0 & 0 & 0 & 0 & 0 & 0 & 0 & 0 \\
\hline Isobutanol & 0 & 0 & 0 & 0 & 0 & 0 & 0 & 0 & 0 & 0 & 0 & 0 & 0 & 0 \\
\hline N-Butanol & 0 & 0 & 0 & 0 & 0 & 0 & 0 & 0 & 0 & 0 & 0 & 0 & 0 & 0 \\
\hline 1-Pentanol & 0 & 0 & 0 & 0 & 0 & 0 & 0 & 0 & 0 & 0 & 0 & 0 & 0 & 0 \\
\hline
\end{tabular}


Table B.1. (contd)

\begin{tabular}{|c|c|c|c|c|c|c|c|c|c|c|c|c|c|c|}
\hline Stream No. & 1938 & 1940 & 1943 & 1944 & 1945 & 1946 & 1948 & 1949 & 1950 & 1951 & 1952 & 1953 & 1954 & 1955 \\
\hline Temp F & 575.2682 & 715.0002 & 573.7587 & 1000 & 456.3709 & 720 & 573.7587 & 1000 & 179 & 575.2682 & 176 & 456.3709 & 456.3709 & 715.0002 \\
\hline Pres psia & 1280 & 450 & 1265 & 1265 & 450 & 450 & 1265 & 1265 & 1280 & 1280 & 450 & 450 & 450 & 1265 \\
\hline Enth MMBtu/h & -711.23 & -265.69 & -908.2 & -857.86 & -447.85 & -434.1 & -402.44 & -380.13 & -676.19 & -572.22 & -530.9 & -447.85 & -447.85 & -31.172 \\
\hline Vapor mass fraction & 1 & 1 & 1 & 1 & 0.98969 & 1 & 1 & 1 & 0 & 1 & 0 & 0.98969 & 0.98969 & 1 \\
\hline Total lb/h & 125000 & 48280.1992 & 159635.016 & \begin{tabular}{|l|}
159635.016 \\
\end{tabular} & \begin{tabular}{|l|}
78924.0547 \\
\end{tabular} & \begin{tabular}{|l|}
78924.0547 \\
\end{tabular} & 70736.875 & 70736.875 & 100568.242 & \begin{tabular}{|l|}
100568.242 \\
\end{tabular} & \begin{tabular}{|l|}
78924.0547 \\
\end{tabular} & 78924.0547 & \begin{tabular}{|l|}
78924.0547 \\
\end{tabular} & 5612.6958 \\
\hline \multicolumn{15}{|l|}{ Flowrates in $\mathrm{lb} / \mathrm{h}$} \\
\hline Oxygen & 0 & 0 & 0 & 0 & 0 & 0 & 0 & 0 & 0 & 0 & 0 & 0 & 0 & 0 \\
\hline Nitrogen & 0 & 0 & 0 & 0 & 0 & 0 & 0 & 0 & 0 & 0 & 0 & 0 & 0 & 0 \\
\hline Argon & 0 & 0 & 0 & 0 & 0 & 0 & 0 & 0 & 0 & 0 & 0 & 0 & 0 & 0 \\
\hline Carbon & 0 & 0 & 0 & 0 & 0 & 0 & 0 & 0 & 0 & 0 & 0 & 0 & 0 & 0 \\
\hline Hydrogen & 0 & 0 & 0 & 0 & 0 & 0 & 0 & 0 & 0 & 0 & 0 & 0 & 0 & 0 \\
\hline Carbon Monoxide & 0 & 0 & 0 & 0 & 0 & 0 & 0 & 0 & 0 & 0 & 0 & 0 & 0 & 0 \\
\hline Carbon Dioxide & 0 & 0 & 0 & 0 & 0 & 0 & 0 & 0 & 0 & 0 & 0 & 0 & 0 & 0 \\
\hline Methane & 0 & 0 & 0 & 0 & 0 & 0 & 0 & 0 & 0 & 0 & 0 & 0 & 0 & 0 \\
\hline Acetylene & 0 & 0 & 0 & 0 & 0 & 0 & 0 & 0 & 0 & 0 & 0 & 0 & 0 & 0 \\
\hline Ethylene & 0 & 0 & 0 & 0 & 0 & 0 & 0 & 0 & 0 & 0 & 0 & 0 & 0 & 0 \\
\hline Ethane & 0 & 0 & 0 & 0 & 0 & 0 & 0 & 0 & 0 & 0 & 0 & 0 & 0 & 0 \\
\hline Propane & 0 & 0 & 0 & 0 & 0 & 0 & 0 & 0 & 0 & 0 & 0 & 0 & 0 & 0 \\
\hline Water & 125000 & 48280.1992 & 159635.016 & 159635.016 & \begin{tabular}{|l|}
78924.0547 \\
\end{tabular} & \begin{tabular}{|l|}
78924.0547 \\
\end{tabular} & 70736.875 & 70736.875 & 100568.242 & 100568.242 & \begin{tabular}{|l|l|}
78924.0547 \\
\end{tabular} & \begin{tabular}{|l|}
78924.0547 \\
\end{tabular} & \begin{tabular}{|l|}
78924.0547 \\
\end{tabular} & 5612.6958 \\
\hline Sulphur & 0 & $\begin{array}{r}0 \\
\end{array}$ & 0 & 0 & 0 & 0 & 0 & 0 & 0 & 0 & 0 & 0 & 0 & 0 \\
\hline Carbonyl Sulfide & 0 & 0 & 0 & 0 & 0 & 0 & 0 & 0 & 0 & 0 & 0 & 0 & 0 & 0 \\
\hline Hydrogen Sulfide & 0 & 0 & 0 & 0 & 0 & 0 & 0 & 0 & 0 & 0 & 0 & 0 & 0 & 0 \\
\hline Ammonia & 0 & 0 & 0 & 0 & 0 & 0 & 0 & 0 & 0 & 0 & 0 & 0 & 0 & 0 \\
\hline HydrogenChloride & 0 & 0 & 0 & 0 & 0 & 0 & 0 & 0 & 0 & 0 & 0 & 0 & 0 & 0 \\
\hline Silicon Dioxide & 0 & 0 & 0 & 0 & 0 & 0 & 0 & 0 & 0 & 0 & 0 & 0 & 0 & 0 \\
\hline Calcium Oxide & 0 & 0 & 0 & 0 & 0 & 0 & 0 & 0 & 0 & 0 & 0 & 0 & 0 & 0 \\
\hline Benzene & 0 & 0 & 0 & 0 & 0 & 0 & 0 & 0 & 0 & 0 & 0 & 0 & 0 & 0 \\
\hline Naphthalene & 0 & 0 & 0 & 0 & 0 & 0 & 0 & 0 & 0 & 0 & 0 & 0 & 0 & 0 \\
\hline Hybrid Poplar Ch & 0 & 0 & 0 & 0 & 0 & 0 & 0 & 0 & 0 & 0 & 0 & 0 & 0 & 0 \\
\hline Sulfur Dioxide & 0 & 0 & 0 & 0 & 0 & 0 & 0 & 0 & 0 & 0 & 0 & 0 & 0 & 0 \\
\hline Hydrogen Cyanide & 0 & 0 & 0 & 0 & 0 & 0 & 0 & 0 & 0 & 0 & 0 & 0 & 0 & 0 \\
\hline Nitric Oxide & 0 & 0 & 0 & 0 & 0 & 0 & 0 & 0 & 0 & 0 & 0 & 0 & 0 & 0 \\
\hline Methanol & 0 & 0 & 0 & 0 & 0 & 0 & 0 & 0 & 0 & 0 & 0 & 0 & 0 & 0 \\
\hline Ethanol & 0 & 0 & 0 & 0 & 0 & 0 & 0 & 0 & 0 & 0 & 0 & 0 & 0 & 0 \\
\hline Isopropanol & 0 & 0 & 0 & 0 & 0 & 0 & 0 & 0 & 0 & 0 & 0 & 0 & 0 & 0 \\
\hline N-Propanol & 0 & 0 & 0 & 0 & 0 & 0 & 0 & 0 & 0 & 0 & 0 & 0 & 0 & 0 \\
\hline Isobutanol & 0 & 0 & 0 & 0 & 0 & 0 & 0 & 0 & 0 & 0 & 0 & 0 & 0 & 0 \\
\hline N-Butanol & 0 & 0 & 0 & 0 & 0 & 0 & 0 & 0 & 0 & 0 & 0 & 0 & 0 & 0 \\
\hline 1-Pentanol & 0 & 0 & 0 & 0 & 0 & 0 & 0 & 0 & 0 & 0 & 0 & 0 & 0 & 0 \\
\hline
\end{tabular}


Table B.1. (contd)

\begin{tabular}{|c|c|c|c|c|c|c|c|c|}
\hline Stream No. & 1956 & 1961 & 1962 & 1971 & 1972 & 1973 & 1974 & 1975 \\
\hline Temp F & 573.7568 & 259.3482 & 259.3462 & 179 & 465 & 574.2614 & 574.2614 & 574.2614 \\
\hline Pres psia & 1265 & 35 & 35 & 1280 & 1275 & 1270 & 1270 & 1270 \\
\hline Enth MMBtu/h & -35.286 & -161.95 & -188.59 & -1110.7 & -1060.8 & -940.77 & -9.3534 & -931.42 \\
\hline Vapor mass fraction & $1.00 \mathrm{E}-08$ & 1 & 0 & 0 & 0 & 0.99099 & 0 & 1 \\
\hline Total $\mathrm{lb} / \mathrm{h}$ & 5612.6958 & 28392.0762 & 28392.0762 & 165197.547 & 165197.547 & 165197.547 & 1487.9614 & 163709.578 \\
\hline Flowrates in $\mathrm{lb} / \mathrm{h}$ & & & & & & & & \\
\hline Oxygen & 0 & 0 & 0 & 0 & 0 & 0 & 0 & 0 \\
\hline Nitrogen & 0 & 0 & 0 & 0 & 0 & 0 & 0 & 0 \\
\hline Argon & 0 & 0 & 0 & 0 & 0 & 0 & 0 & 0 \\
\hline Carbon & 0 & 0 & 0 & 0 & 0 & 0 & 0 & 0 \\
\hline Hydrogen & 0 & 0 & 0 & 0 & 0 & 0 & 0 & 0 \\
\hline Carbon Monoxide & 0 & 0 & 0 & 0 & 0 & 0 & 0 & 0 \\
\hline Carbon Dioxide & 0 & 0 & 0 & 0 & 0 & 0 & 0 & 0 \\
\hline Methane & 0 & 0 & 0 & 0 & 0 & 0 & 0 & 0 \\
\hline Acetylene & 0 & 0 & 0 & 0 & 0 & 0 & 0 & 0 \\
\hline Ethylene & 0 & 0 & 0 & 0 & 0 & 0 & 0 & 0 \\
\hline Ethane & 0 & 0 & 0 & 0 & 0 & 0 & 0 & 0 \\
\hline Propane & 0 & 0 & 0 & 0 & 0 & 0 & 0 & 0 \\
\hline \begin{tabular}{|l} 
Water \\
\end{tabular} & 5612.6958 & 28392.0762 & 28392.0762 & 165197.547 & 165197.547 & 165197.547 & 1487.9614 & 163709.578 \\
\hline \begin{tabular}{|l} 
Sulphur \\
\end{tabular} & 0 & 0 & $\begin{array}{r}0 \\
\end{array}$ & 0 & $\begin{array}{r}0 \\
\end{array}$ & $\begin{array}{r}0 \\
\end{array}$ & 0 & 0 \\
\hline Carbonyl Sulfide & 0 & 0 & 0 & 0 & 0 & 0 & 0 & 0 \\
\hline Hydrogen Sulfide & 0 & 0 & 0 & 0 & 0 & 0 & 0 & 0 \\
\hline Ammonia & 0 & 0 & 0 & 0 & 0 & 0 & 0 & 0 \\
\hline HydrogenChloride & 0 & 0 & 0 & 0 & 0 & 0 & 0 & 0 \\
\hline Silicon Dioxide & 0 & 0 & 0 & 0 & 0 & 0 & 0 & 0 \\
\hline Calcium Oxide & 0 & 0 & 0 & 0 & 0 & 0 & 0 & 0 \\
\hline Benzene & 0 & 0 & 0 & 0 & 0 & 0 & 0 & 0 \\
\hline Naphthalene & 0 & 0 & 0 & 0 & 0 & 0 & 0 & 0 \\
\hline Hybrid Poplar Ch & 0 & 0 & 0 & 0 & 0 & 0 & 0 & 0 \\
\hline Sulfur Dioxide & 0 & 0 & 0 & 0 & 0 & 0 & 0 & 0 \\
\hline Hydrogen Cyanide & 0 & 0 & 0 & 0 & 0 & 0 & 0 & 0 \\
\hline Nitric Oxide & 0 & 0 & 0 & 0 & 0 & 0 & 0 & 0 \\
\hline Methanol & 0 & 0 & 0 & 0 & 0 & 0 & 0 & 0 \\
\hline Ethanol & 0 & 0 & 0 & 0 & 0 & 0 & 0 & 0 \\
\hline Isopropanol & 0 & 0 & 0 & 0 & 0 & 0 & 0 & 0 \\
\hline N-Propanol & 0 & 0 & 0 & 0 & 0 & 0 & 0 & 0 \\
\hline Isobutanol & 0 & 0 & 0 & 0 & 0 & 0 & 0 & 0 \\
\hline N-Butanol & 0 & 0 & 0 & 0 & 0 & 0 & 0 & 0 \\
\hline 1-Pentanol & 0 & 0 & 0 & 0 & 0 & 0 & 0 & 0 \\
\hline
\end{tabular}




\section{B.2 Oxygen Blown Directly Heated Gasifier Model}

Figure B.8 shows the process flow diagram for the Base Case directly-heated gasifier system. Figures B.9 to B.15 show the flow sheets for each main area in the system. Table B.2 lists corresponding heat and material balances. 


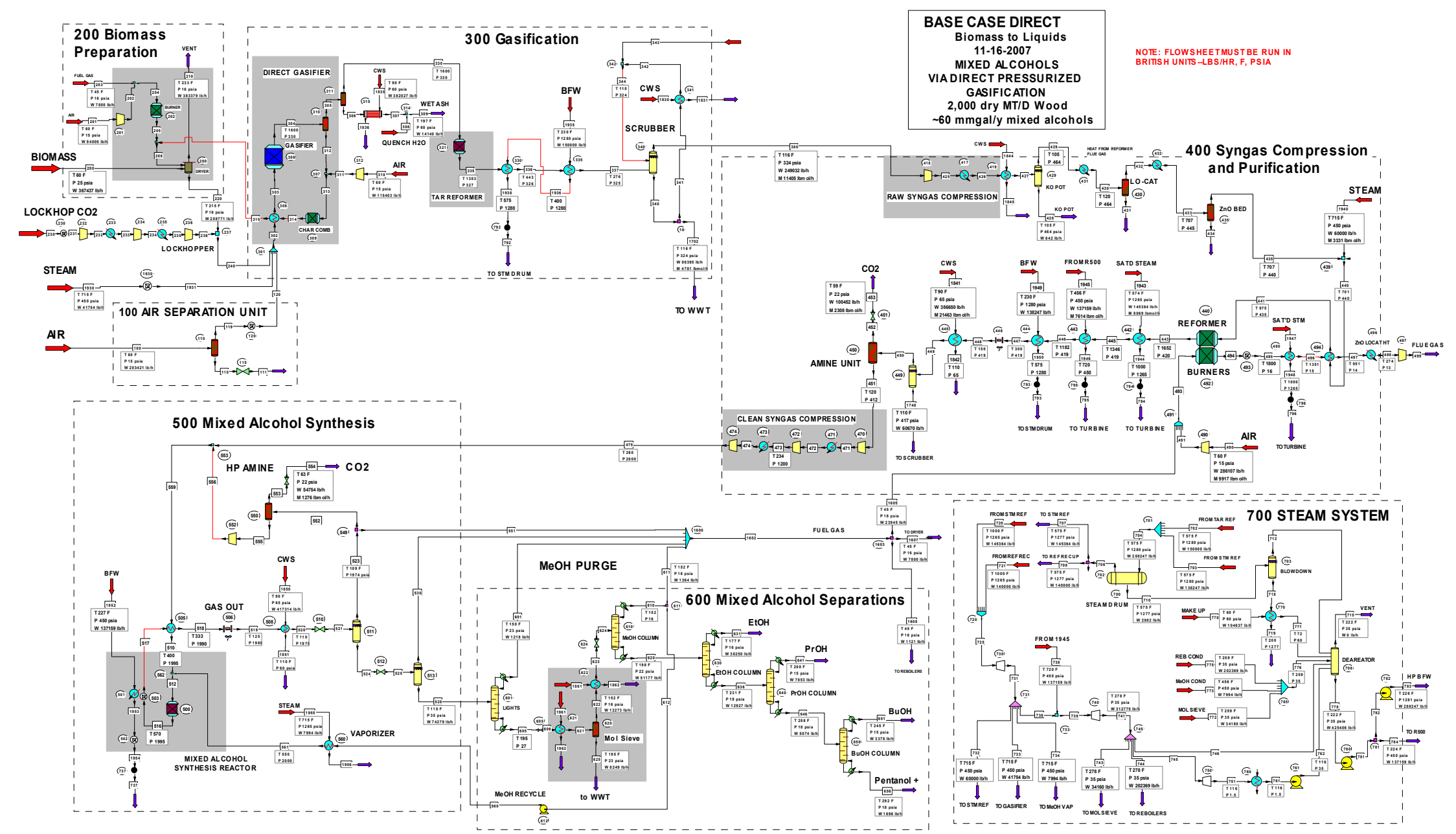

Figure B.8. Flow Sheet for Mixed Alcohol Production - Directly Heated Gasifier Base Case 


\section{AIR SEPARATION UNIT}

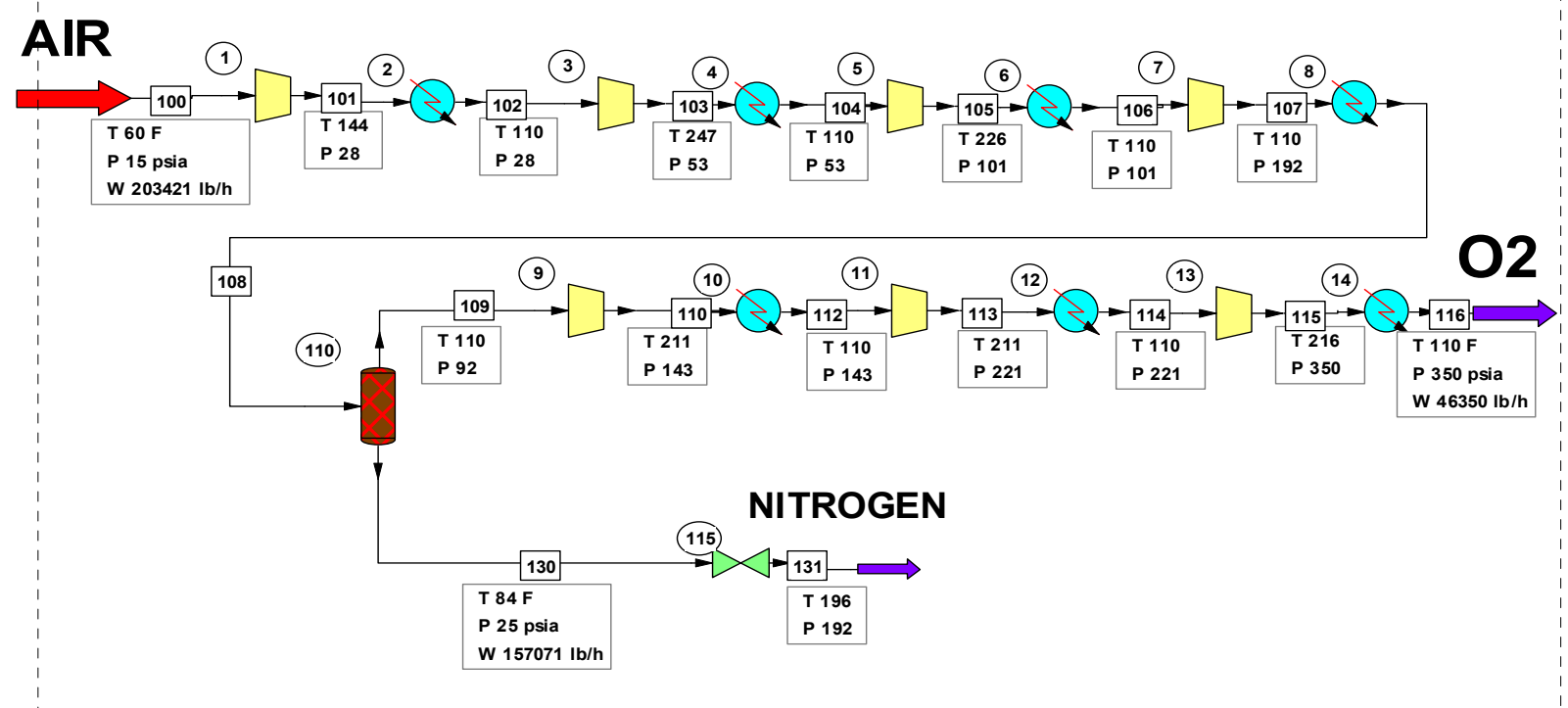

Figure B.9. Flow Sheet for Area 100 Air Separation Unit - Directly Heated Gasifier Base Case

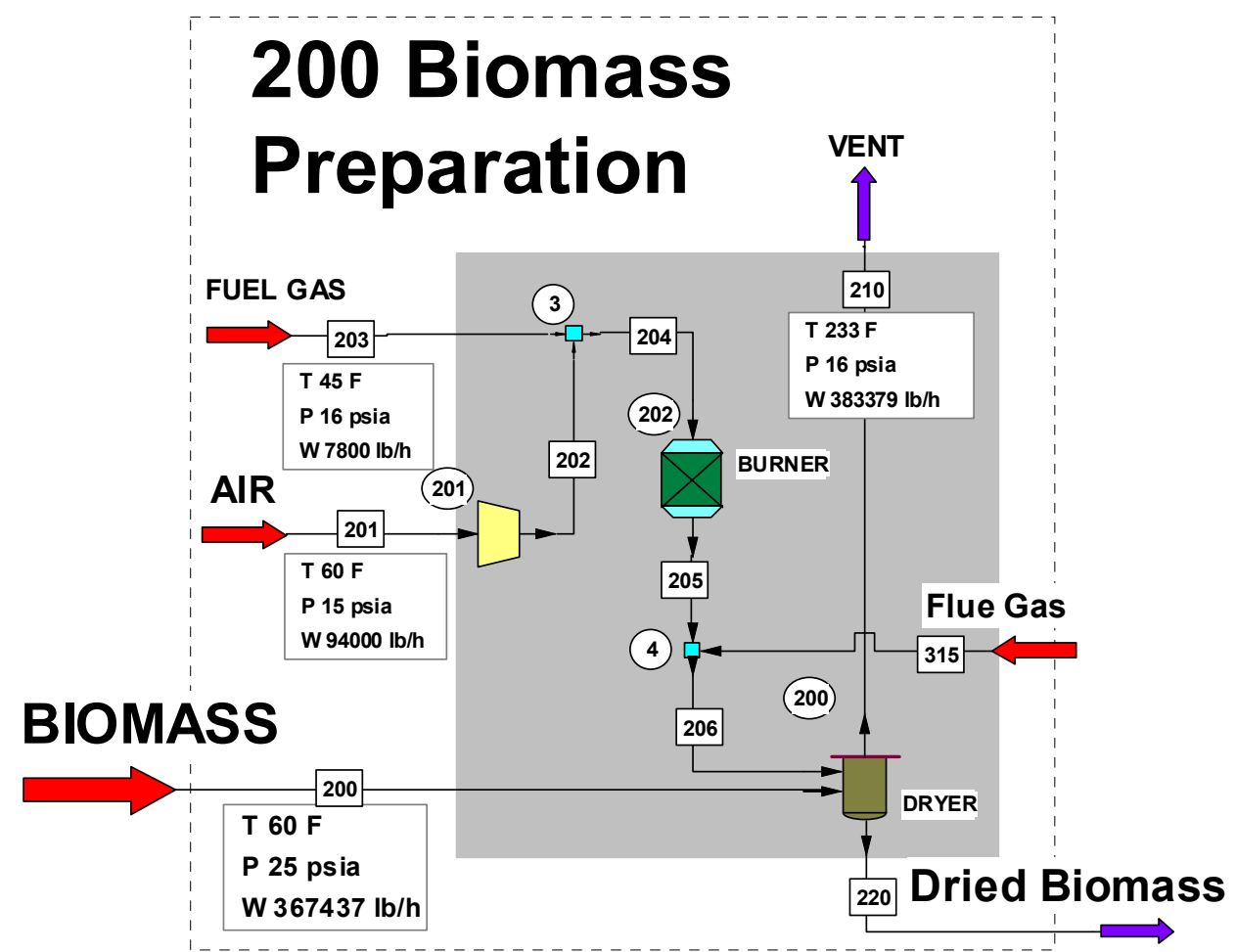

Figure B.10. Flow Sheet for Area 200 Biomass Preparation - Directly Heated Gasifier Base Case 


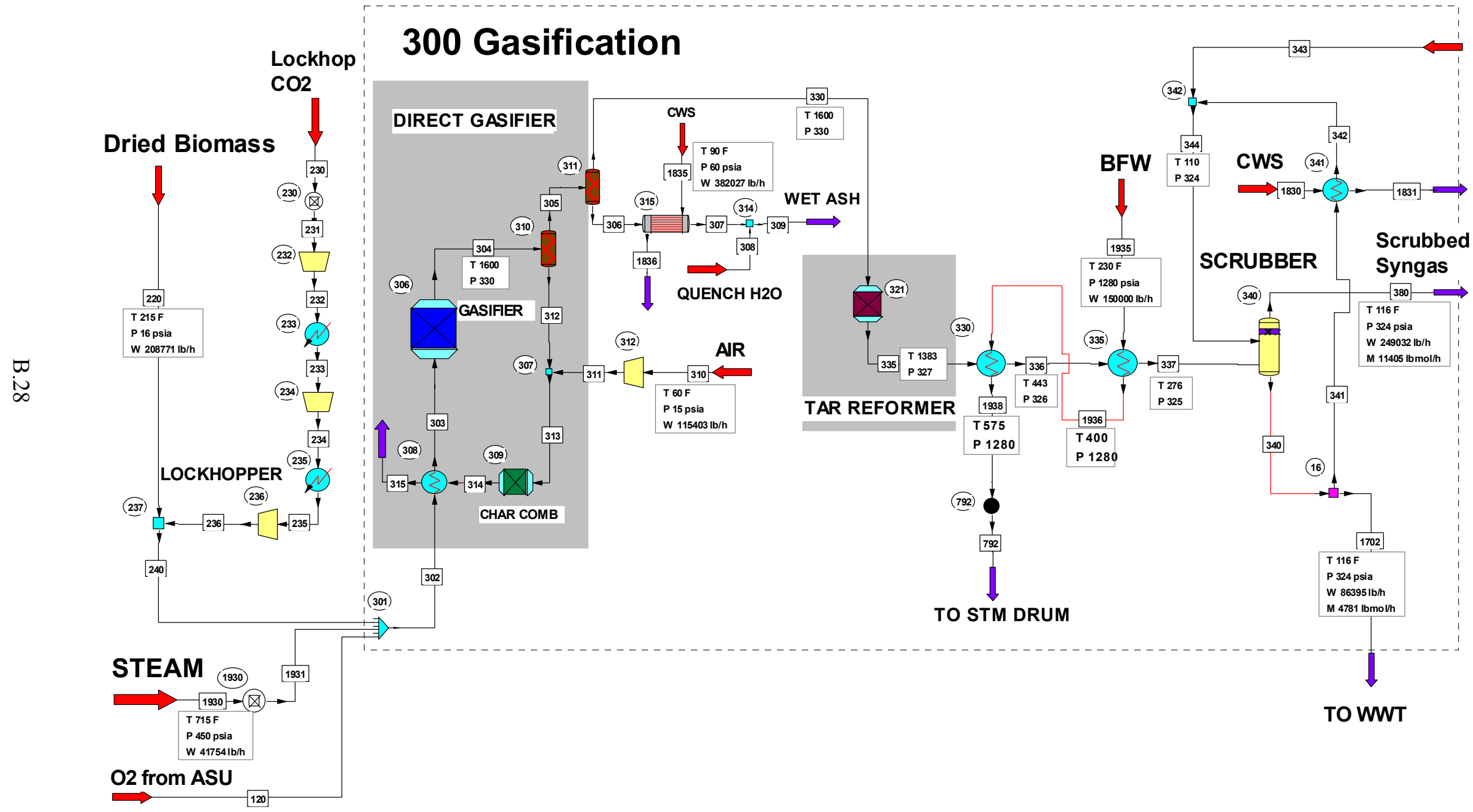

Figure B.11. Flow Sheet for Area 300 Gasification - Directly Heated Gasifier Base Case 


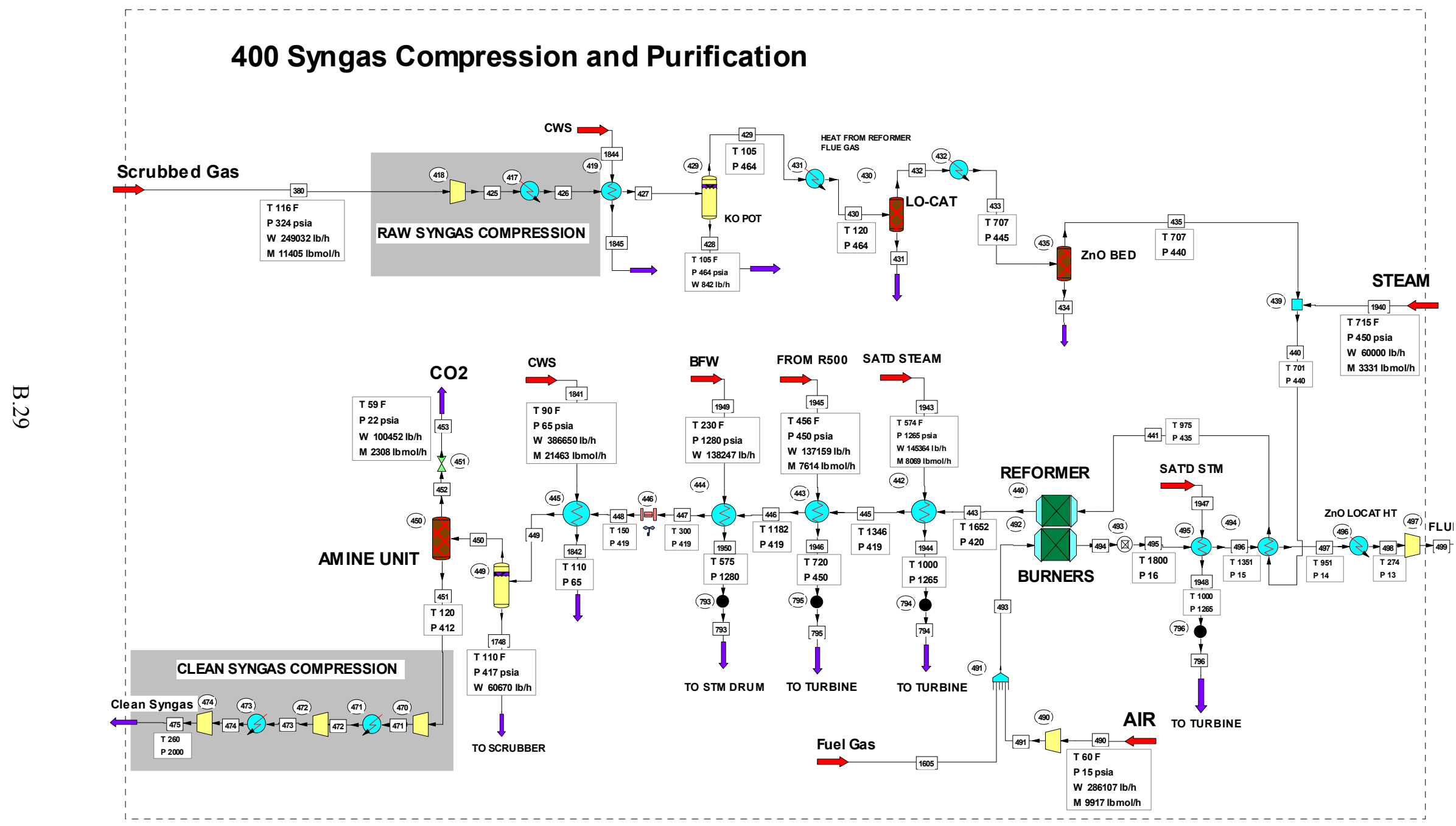

Figure B.12. Flow Sheet for Area 400 Syngas Compression and Purification - Directly Heated Gasifier Base Case 


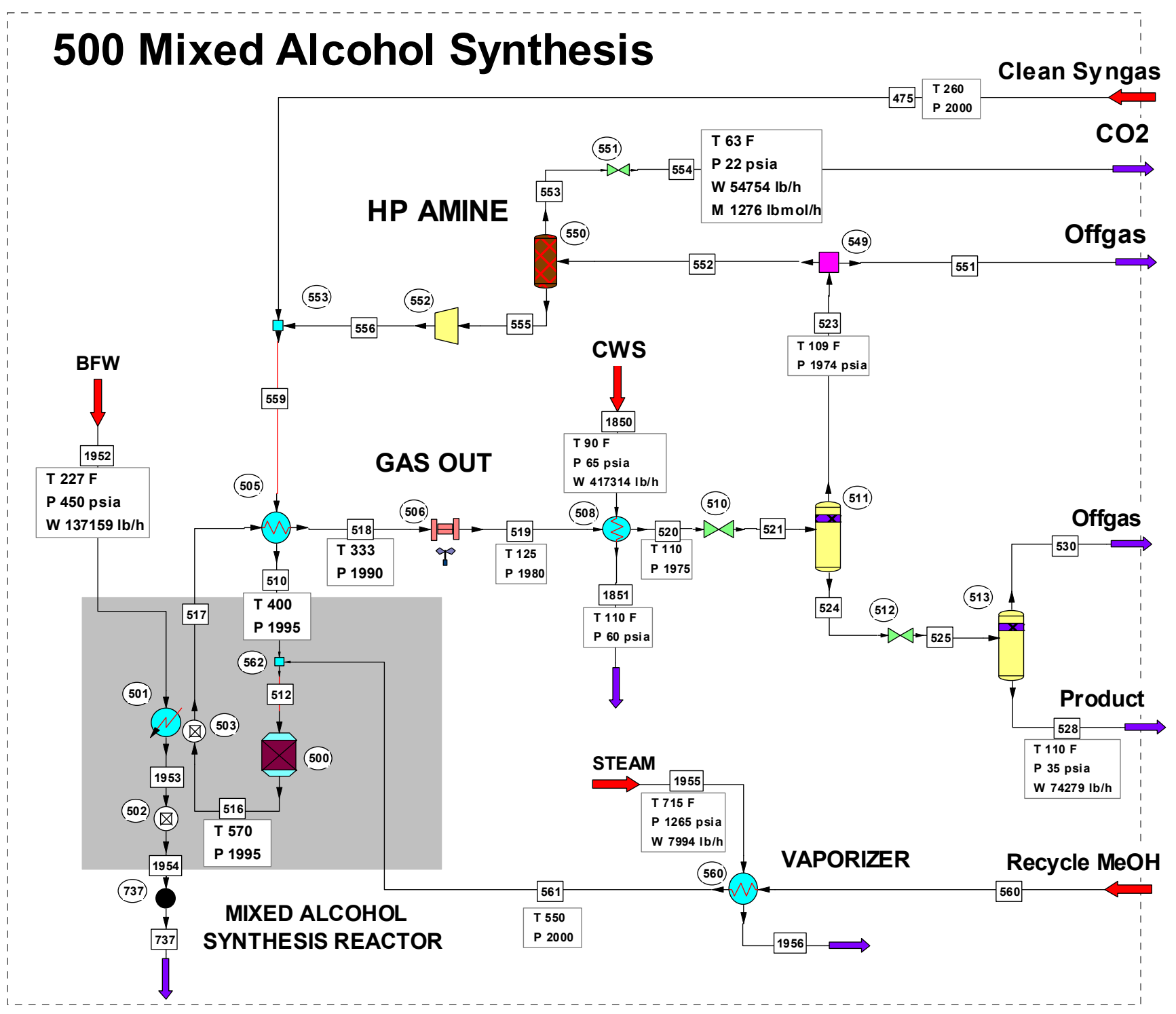

Figure B.13. Flow Sheet for Area 500 Mixed Alcohol Synthesis - Directly Heated Gasifier Base Case 


\section{Mixed Alcohol Separations}

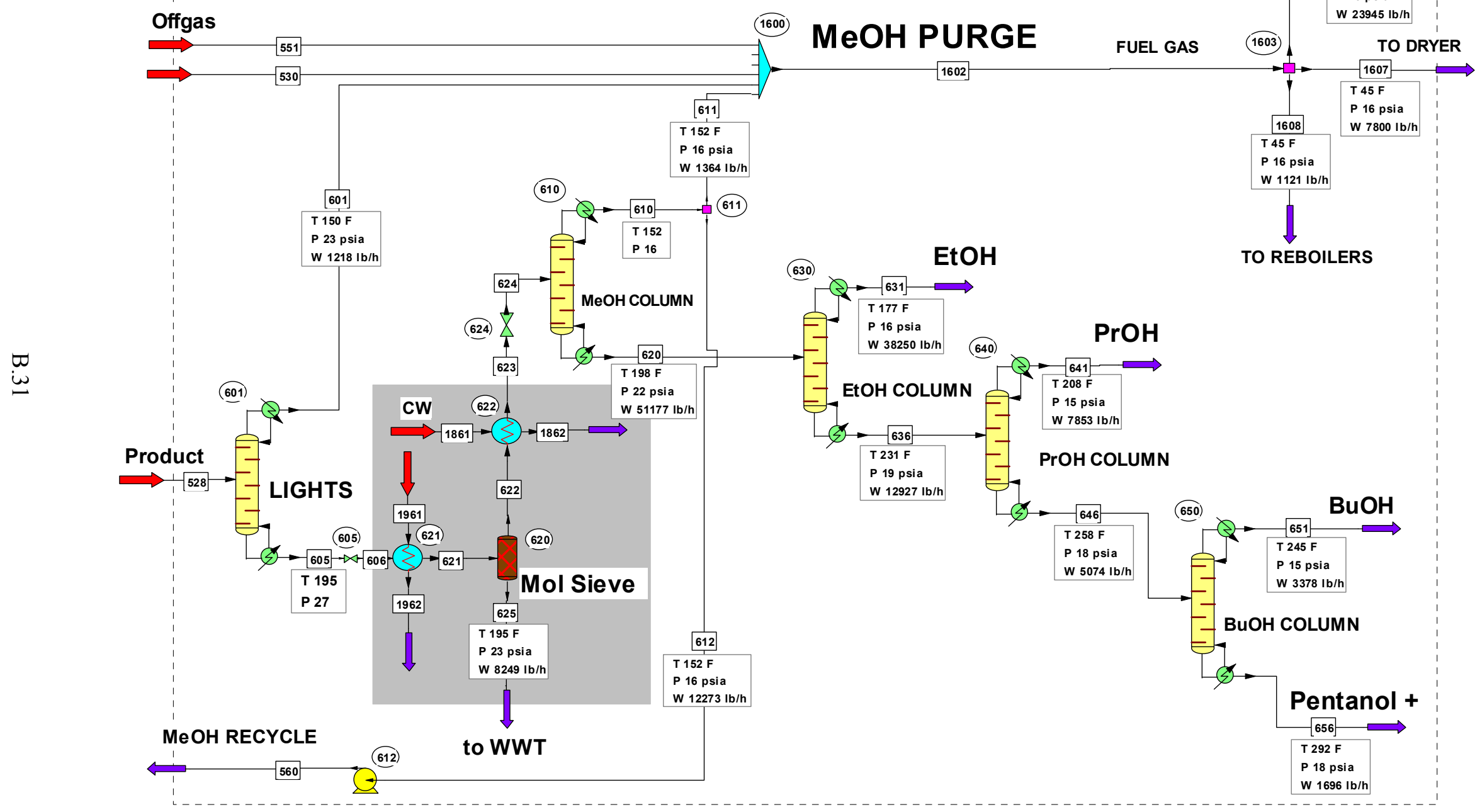

Figure B.14. Flow Sheet for Area 600 Mixed Alcohol Separation - Directly Heated Gasifier Base Case 


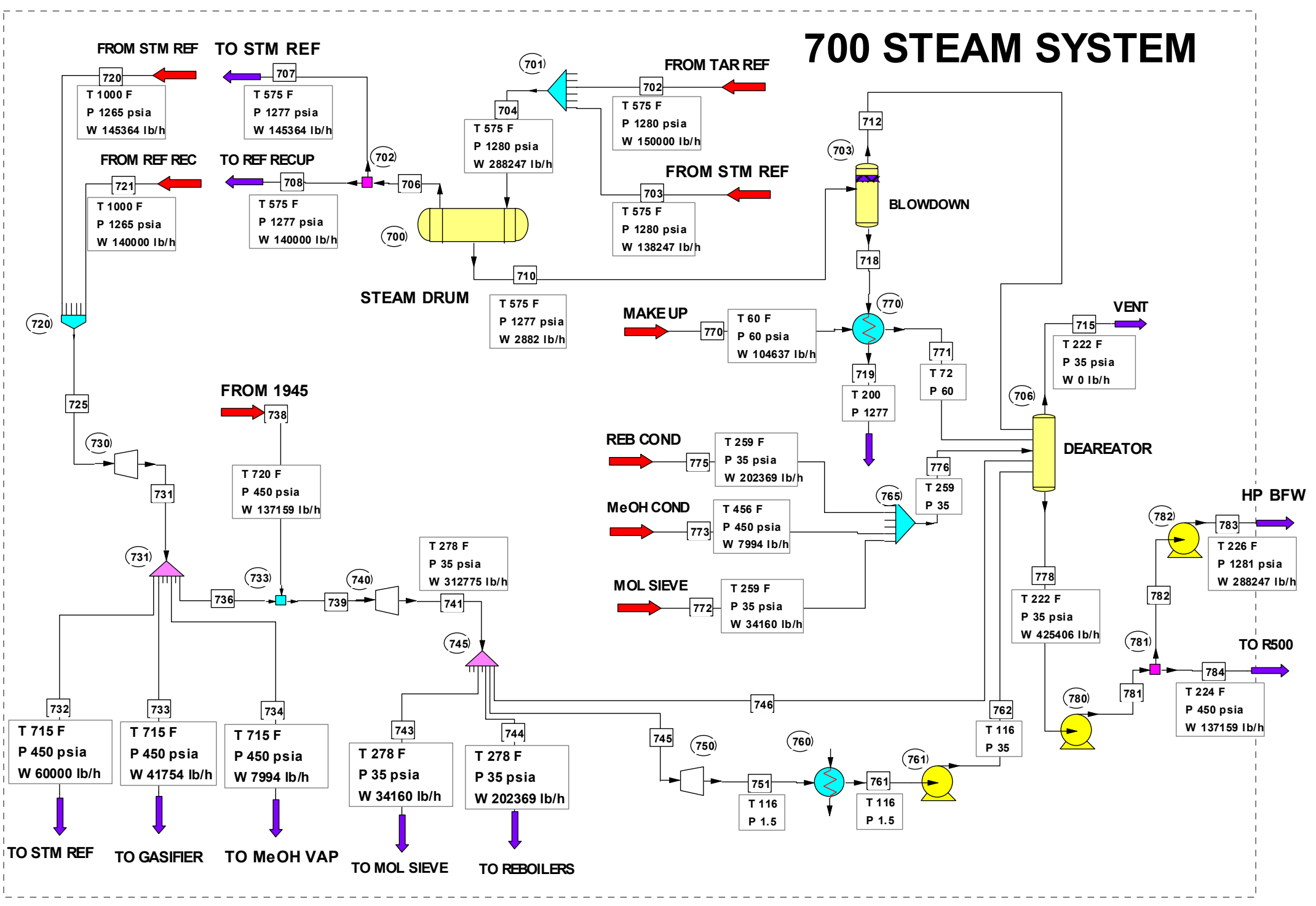

Figure B.15. Flow Sheet for Area 700 Steam System - Directly Heated Gasifier Base Case 
Table B.2. Heat and Material Balances for the Base Case Indirectly Heated Gasifier

\begin{tabular}{|c|c|c|c|c|c|c|c|c|c|c|c|c|c|c|}
\hline Stream No. & 100 & 110 & 111 & 119 & 120 & 200 & 201 & 202 & 203 & 204 & 205 & 206 & 210 & 220 \\
\hline Temp F & 60 & 60 & 41.973 & 60 & 60 & 60 & 60 & 91.4583 & 44.7055 & 81.4333 & 3343.777 & 3024.4728 & 232.8891 & 215 \\
\hline Pres psia & 14.696 & 350 & 25 & 350 & 350 & 25 & 14.696 & 17 & 16 & 16 & 16 & 16 & 16 & 16 \\
\hline Enth MMBtu/h & -26.033 & -28.406 & -28.406 & -0.29269 & -0.29269 & \begin{tabular}{|l|}
-1744.9 \\
\end{tabular} & -0.39461 & 0.31979 & -16.996 & -16.676 & -16.676 & -48.51 & -1147.6 & -645.89 \\
\hline Vapor mass fraction & 0.99137 & 0.97527 & 0.97805 & 1 & 1 & 0 & 1 & 1 & 0.97455 & 1 & 1 & & 1 & 0 \\
\hline Total lb/h & 203421 & 157070.594 & 157070.594 & \begin{tabular}{|l|}
46350.4297 \\
\end{tabular} & 46350.418 & \begin{tabular}{|l|}
367437.406 \\
\end{tabular} & 94000.0078 & \begin{tabular}{|l|}
94000.0078 \\
\end{tabular} & 7800.002 & 101800.023 & 101799.828 & 224713.297 & 383379.438 & 208771.25 \\
\hline Flowrates in $\mathrm{lb} / \mathrm{h}$ & & & & & & & & & & & & & & \\
\hline Oxygen & 46153.1094 & 39.6902 & 39.6902 & 46113.4453 & 46113.4336 & 0 & 21894.0449 & \begin{tabular}{|l|}
21894.0449 \\
\end{tabular} & 0 & 21894.0449 & 2775.2058 & 6316.5342 & 6316.5342 & 0 \\
\hline Nitrogen & 150629.688 & 150547 & 150547 & 82.8464 & \begin{tabular}{|l|}
82.8463 \\
\end{tabular} & 0 & 72106 & 72106 & 210.98 & 72317 & 72147.5469 & 160343.359 & 160343.359 & 0 \\
\hline Argon & 2568.9688 & 2414.8308 & 2414.8308 & 154.1382 & 154.1381 & 0 & 0 & 0 & 36.6478 & 36.6478 & 36.6478 & 36.6478 & 36.6478 & 0 \\
\hline Carbon & 0 & 0 & 0 & 0 & 0 & 0 & 0 & 0 & 0 & 0 & 0 & 0.0002 & 0.0002 & 0 \\
\hline Hydrogen & 0 & 0 & 0 & 0 & 0 & 0 & 0 & 0 & 98.5847 & 98.5847 & 4.3963 & 14.864 & 14.864 & 0 \\
\hline Carbon Monoxide & 0 & 0 & 0 & 0 & 0 & 0 & 0 & 0 & 1570.4126 & 1570.4126 & 187.3857 & 1167.8114 & 1167.8114 & 0 \\
\hline Carbon Dioxide & 100.2928 & 100.2928 & 100.2928 & 0 & 0 & 0 & 0 & 0 & 1052.9977 & 1052.9977 & 15515.5254 & 36894.2344 & 36894.2344 & 0 \\
\hline Methane & 0 & 0 & 0 & 0 & 0 & 0 & 0 & 0 & 3891.4175 & 3891.4175 & $\begin{array}{l}0.0001 \\
\end{array}$ & 0.0001 & $\begin{array}{l}0.0001 \\
\end{array}$ & 0 \\
\hline Acetylene & 0 & 0 & 0 & 0 & 0 & 0 & 0 & 0 & 0 & 0 & 0 & 0 & 0 & 0 \\
\hline Ethylene & 0 & 0 & 0 & 0 & 0 & 0 & 0 & 0 & 0.1079 & 0.1079 & 0.0001 & 0.0001 & 0.0001 & 0 \\
\hline Ethane & 0 & 0 & 0 & 0 & 0 & 0 & 0 & 0 & 178.7961 & 178.7961 & 0.0001 & 0.0001 & 0.0001 & 0 \\
\hline Propane & 0 & 0 & 0 & 0 & 0 & 0 & 0 & 0 & 0 & 0 & 0 & 0 & 0 & 0 \\
\hline Water & 3968.927 & 3968.928 & 3968.9272 & 0 & 0 & 183718.703 & 0 & 0 & 31.0094 & 31.0094 & 10763.7422 & 18780.541 & 177446.688 & 25052.5488 \\
\hline Sulphur & 0 & 0 & 0 & 0 & 0 & $\begin{array}{r}0 \\
\end{array}$ & 0 & 0 & 0 & 0 & $\begin{array}{r}0 \\
\end{array}$ & 0.0002 & $\begin{array}{l}0.0002 \\
\end{array}$ & 0 \\
\hline Carbonyl Sulfide & 0 & 0 & 0 & 0 & 0 & 0 & 0 & 0 & 0 & 0 & 0 & 0 & 0 & 0 \\
\hline Hydrogen Sulfide & 0 & 0 & 0 & 0 & 0 & 0 & 0 & 0 & 0 & 0 & 0 & 0 & 0 & 0 \\
\hline Ammonia & 0 & 0 & 0 & 0 & 0 & 0 & 0 & 0 & 3.639 & 3.639 & 0.0001 & 0.0001 & 0.0001 & 0 \\
\hline HydrogenChloride & 0 & 0 & 0 & 0 & 0 & 0 & 0 & 0 & 0 & 0 & 0 & 0 & 0 & 0 \\
\hline Calcium Oxide & 0 & 0 & 0 & 0 & 0 & 0 & 0 & 0 & 0 & 0 & 0 & 0 & 0 & 0 \\
\hline Benzene & 0 & 0 & 0 & 0 & 0 & 0 & 0 & 0 & 0 & 0 & 0 & 0 & 0 & 0 \\
\hline Naphthalene & 0 & 0 & 0 & 0 & 0 & 0 & 0 & 0 & 0 & 0 & 0 & 0 & 0 & 0 \\
\hline Hybrid Poplar Ch & 0 & 0 & 0 & 0 & 0 & \begin{tabular}{|l|}
183718.703 \\
\end{tabular} & 0 & 0 & 0 & 0 & 0 & 0 & 0 & 183718.703 \\
\hline Sulfur Dioxide & 0 & 0 & 0 & 0 & 0 & \begin{tabular}{|r}
0 \\
\end{tabular} & 0 & 0 & 0 & 0 & 0 & 6.0849 & 6.0849 & 0 \\
\hline Hydrogen Cyanide & 0 & 0 & 0 & 0 & 0 & 0 & 0 & 0 & 0.0633 & 0.0633 & 0.0001 & 0.0001 & 0.0001 & 0 \\
\hline Nitric Oxide & 0 & 0 & 0 & 0 & 0 & 0 & 0 & 0 & 0 & 0 & 369.3846 & 1153.2338 & 1153.2338 & 0 \\
\hline Methanol & 0 & 0 & 0 & 0 & 0 & 0 & 0 & 0 & 561.6821 & 561.6821 & 0.0001 & 0.0001 & 0.0001 & 0 \\
\hline Ethanol & 0 & 0 & 0 & 0 & 0 & 0 & 0 & 0 & 145.2101 & 145.2101 & 0.0002 & 0.0002 & 0.0002 & 0 \\
\hline Isopropanol & 0 & 0 & 0 & 0 & 0 & 0 & 0 & 0 & $\begin{array}{r}0 \\
\end{array}$ & 0 & 0 & 0 & 0 & 0 \\
\hline N-Propanol & 0 & 0 & 0 & 0 & 0 & 0 & 0 & 0 & 14.1388 & 14.1388 & 0.0002 & 0.0002 & 0.0002 & 0 \\
\hline Isobutanol & 0 & 0 & 0 & 0 & 0 & 0 & 0 & 0 & 0 & 0 & 0 & 0 & 0 & 0 \\
\hline N-Butanol & 0 & 0 & 0 & 0 & 0 & 0 & 0 & 0 & 2.965 & 2.965 & 0.0002 & 0.0002 & 0.0002 & 0 \\
\hline 1-Pentanol & 0 & 0 & 0 & 0 & 0 & 0 & 0 & 0 & 1.3495 & 1.3495 & 0.0002 & 0.0002 & 0.0002 & 0 \\
\hline
\end{tabular}


Table B.2. (contd)

\begin{tabular}{|c|c|c|c|c|c|c|c|c|c|c|c|c|c|c|}
\hline Stream No. & 230 & 231 & 232 & 233 & 234 & 235 & 236 & 240 & 302 & 303 & 304 & 305 & 306 & 307 \\
\hline Temp F & 70 & 70 & 276.024 & 140 & 263.2057 & 140 & 282.0417 & 214.7715 & 365.9011 & 433 & 1600 & 1600 & 1600 & 300 \\
\hline Pres psia & 22 & 22 & 75 & 75 & 150 & 150 & 330 & 330 & 330 & 330 & 330 & 330 & 330 & 330 \\
\hline Enth MMBtu/h & -23.166 & -23.166 & -22.902 & -23.085 & -22.927 & \begin{tabular}{l|}
-23.096 \\
\end{tabular} & -22.916 & -668.8 & -898.87 & -857.4 & \begin{tabular}{|l|}
-857.53 \\
\end{tabular} & -865.88 & -41.84 & -49.483 \\
\hline Vapor mass fraction & 1 & 1 & 1 & 1 & 1 & 1 & 1 & 0.19779 & 0.67758 & 1 & 0.98309 & 0.98301 & 0.0003125 & 0.0003125 \\
\hline Total lb/h & 6023.0806 & 6023.0806 & 6023.0806 & 6023.0806 & 6023.0806 & 6023.0806 & 6023.0806 & 214794.344 & 302898.5 & 302898.5 & 302898.313 & 295388.375 & 4960.4048 & 4960.4048 \\
\hline Flowrates in $\mathrm{lb} / \mathrm{h}$ & & & & & & & & & & & & & 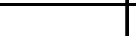 & \\
\hline Oxygen & 0 & 0 & 0 & 0 & 0 & 0 & 0 & 0 & 46113.4336 & 46113.4336 & 307.1113 & 0 & 0 & 0 \\
\hline Nitrogen & 0 & 0 & 0 & 0 & 0 & 0 & 0 & 0 & 82.8463 & 82.8463 & 120.38 & 82.8463 & 0 & 0 \\
\hline Argon & 0 & 0 & 0 & 0 & 0 & 0 & 0 & 0 & 154.1381 & 154.1381 & 154.1381 & 154.1381 & 0 & 0 \\
\hline Carbon & 0 & 0 & 0 & 0 & 0 & 0 & 0 & 0 & 0 & 0 & 6254.937 & 0 & 0 & 0 \\
\hline Hydrogen & 0 & 0 & 0 & 0 & 0 & 0 & 0 & 0 & 0 & 0 & 4562.5776 & 3655.0735 & 0 & 0 \\
\hline Carbon Monoxide & 0 & 0 & 0 & 0 & 0 & 0 & 0 & 0 & 0 & 0 & 49736.6641 & 49736.7148 & 0 & 0 \\
\hline Carbon Dioxide & 6023.0806 & 6023.0806 & 6023.0806 & 6023.0806 & 6023.0806 & 6023.0806 & 6023.0806 & 6023.0806 & 6023.0806 & 6023.0806 & 135752.594 & 135752.672 & 0 & 0 \\
\hline Methane & 0 & 0 & 0 & 0 & 0 & 0 & 0 & 0 & 0 & 0 & 21336.9355 & 21336.9434 & 0 & 0 \\
\hline Acetylene & 0 & 0 & 0 & 0 & 0 & 0 & 0 & 0 & 0 & 0 & 0 & 0 & 0 & 0 \\
\hline Ethylene & 0 & 0 & 0 & 0 & 0 & 0 & 0 & 0 & 0 & 0 & 1041.2955 & 1041.2961 & 0 & 0 \\
\hline Ethane & 0 & 0 & 0 & 0 & 0 & 0 & 0 & 0 & 0 & 0 & 1948.759 & 1948.76 & 0 & 0 \\
\hline Propane & 0 & 0 & 0 & 0 & 0 & 0 & 0 & 0 & 0 & 0 & 0 & 0 & 0 & 0 \\
\hline Water & 0 & 0 & 0 & 0 & 0 & 0 & 0 & 25052.5488 & 66806.3047 & 66806.3047 & 62887.375 & 62887.4023 & 0 & 0 \\
\hline Sulphur & 0 & 0 & 0 & 0 & 0 & 0 & 0 & 0 & 0 & $\begin{array}{r}0 \\
\end{array}$ & 3.0449 & 0 & 0 & 0 \\
\hline Carbonyl Sulfide & 0 & 0 & 0 & 0 & 0 & 0 & 0 & 0 & 0 & 0 & 0 & 0 & 0 & 0 \\
\hline Hydrogen Sulfide & 0 & 0 & 0 & 0 & 0 & 0 & 0 & 0 & 0 & 0 & 35.064 & 35.064 & 0 & 0 \\
\hline Ammonia & 0 & 0 & 0 & 0 & 0 & 0 & 0 & 0 & 0 & 0 & 1312.588 & 1312.5884 & 0 & 0 \\
\hline HydrogenChloride & 0 & 0 & 0 & 0 & 0 & 0 & 0 & 0 & 0 & 0 & 18.5296 & 18.5296 & 0 & 0 \\
\hline Calcium Oxide & 0 & 0 & 0 & 0 & 0 & 0 & 0 & 0 & 0 & 0 & 4960.4033 & 4960.4048 & 4960.4048 & 4960.4048 \\
\hline Benzene & 0 & 0 & 0 & 0 & 0 & 0 & 0 & 0 & 0 & 0 & 8488.3242 & 8488.3301 & 0 & 0 \\
\hline Naphthalene & 0 & 0 & 0 & 0 & 0 & 0 & 0 & 0 & 0 & 0 & 3977.6028 & 3977.6035 & 0 & 0 \\
\hline Hybrid Poplar Ch & 0 & 0 & 0 & 0 & 0 & 0 & 0 & 183718.703 & 183718.703 & 183718.703 & 0 & 0 & 0 & 0 \\
\hline Sulfur Dioxide & 0 & 0 & 0 & 0 & 0 & 0 & 0 & 0 & 0 & 0 & 0 & 0 & 0 & 0 \\
\hline Hydrogen Cyanide & 0 & 0 & 0 & 0 & 0 & 0 & 0 & 0 & 0 & 0 & 0 & 0 & 0 & 0 \\
\hline Nitric Oxide & 0 & 0 & 0 & 0 & 0 & $\begin{array}{l}0 \\
\end{array}$ & 0 & 0 & 0 & 0 & 0 & 0 & 0 & 0 \\
\hline Methanol & 0 & 0 & 0 & 0 & 0 & \begin{tabular}{l|l}
0 \\
\end{tabular} & 0 & 0 & 0 & 0 & 0 & 0 & 0 & 0 \\
\hline Ethanol & 0 & 0 & 0 & 0 & 0 & 0 & 0 & 0 & 0 & 0 & 0 & 0 & 0 & 0 \\
\hline Isopropanol & 0 & 0 & 0 & 0 & 0 & 0 & 0 & 0 & 0 & 0 & 0 & 0 & 0 & 0 \\
\hline N-Propanol & 0 & 0 & 0 & 0 & 0 & 0 & 0 & 0 & 0 & 0 & 0 & 0 & 0 & 0 \\
\hline Isobutanol & 0 & 0 & 0 & 0 & 0 & 0 & 0 & 0 & 0 & 0 & 0 & 0 & 0 & 0 \\
\hline N-Butanol & 0 & 0 & 0 & 0 & 0 & 0 & 0 & 0 & 0 & 0 & 0 & 0 & 0 & 0 \\
\hline 1-Pentanol & 0 & 0 & 0 & 0 & 0 & 0 & 0 & 0 & 0 & 0 & 0 & 0 & 0 & 0 \\
\hline
\end{tabular}


Table B.2. (contd)

\begin{tabular}{|c|c|c|c|c|c|c|c|c|c|c|c|c|c|c|}
\hline Stream No. & 308 & 309 & 310 & 311 & 312 & 313 & 314 & 315 & 330 & 335 & 336 & 337 & 340 & 341 \\
\hline Temp F & 90 & 196.9097 & 60 & 123.5755 & 1600 & 371.8523 & 3741.1391 & 2743.6979 & 1600 & 1383 & 443.4863 & 276.2184 & 116.4856 & 116.4856 \\
\hline Pres psia & 60 & 60 & 14.696 & 20 & 330 & 25 & 25 & 25 & 330 & 327 & 326 & 325 & 324 & 324 \\
\hline Enth MMBtu/h & -62.541 & -112.02 & -0.48446 & 1.2888 & 8.3447 & 9.6334 & 9.634 & -31.834 & -824.05 & -775.49 & -896.18 & -922.85 & -58296 & -57713 \\
\hline Vapor mass fraction & 0 & 0 & 1 & 1 & 1 & 1 & 1 & 1 & 1 & & 1 & 0.97371 & 0 & 0 \\
\hline Total lb/h & 9179.9326 & 14140.3379 & 115403.398 & 115403.398 & 7510.1357 & \begin{tabular}{|l|}
122913.539 \\
\end{tabular} & 122913.477 & 122913.5 & 290428 & 290427.5 & 290427.5 & 290427.5 & 8639493 & 8553097 \\
\hline \multicolumn{15}{|l|}{ Flowrates in $\mathrm{lb} / \mathrm{h}$} \\
\hline Oxygen & 0 & 0 & 26879.2227 & 26879.2227 & 307.1115 & 27186.334 & 3541.3291 & 3541.3301 & 0 & 0 & 0 & 0 & 0 & 0 \\
\hline Nitrogen & 0 & 0 & 88524.1797 & 88524.1797 & 37.5337 & 88561.7109 & 88195.7969 & 88195.8203 & 82.8463 & 838.5153 & 838.5153 & 838.5153 & 5.4233 & 5.369 \\
\hline Argon & 0 & 0 & 0 & 0 & 0 & 0 & 0 & $\begin{array}{r}0 \\
\end{array}$ & 154.138 & 154.1381 & 154.1381 & 154.1381 & 2.8519 & 2.8234 \\
\hline Carbon & 0 & 0 & 0 & 0 & 6254.9395 & 6254.9395 & 0.0002 & 0.0002 & 0 & 0 & 0 & 0 & 0 & 0 \\
\hline Hydrogen & 0 & 0 & 0 & 0 & 907.5061 & 907.5061 & 10.4677 & 10.4677 & 3655.0701 & 8376.3105 & 8376.3105 & 8376.3105 & 104.795 & 103.747 \\
\hline Carbon Monoxide & 0 & 0 & 0 & 0 & 0 & 0 & 980.4257 & 980.4258 & 49736.6719 & 82535.7734 & \begin{tabular}{|l|}
82535.7734 \\
\end{tabular} & 82535.7734 & 1129.4772 & 1118.1825 \\
\hline Carbon Dioxide & 0 & 0 & 0 & 0 & 0 & 0 & 21378.709 & 21378.7129 & 135752.594 & 135752.672 & 135752.672 & 135752.672 & 39684.6523 & 39287.8047 \\
\hline Methane & 0 & 0 & 0 & 0 & 0 & 0 & 0 & 0 & 21336.9297 & 17069.5547 & 17069.5547 & 17069.5547 & 280.8862 & 278.0774 \\
\hline Acetylene & 0 & 0 & 0 & 0 & 0 & 0 & 0 & 0 & 0 & 0 & $\begin{array}{r}0 \\
\end{array}$ & 0 & 0 & 0 \\
\hline \begin{tabular}{|l|} 
Ethylene \\
\end{tabular} & 0 & 0 & 0 & 0 & 0 & 0 & 0 & 0 & 1041.295 & 520.6481 & 520.6481 & 520.6481 & 117.1997 & 116.0277 \\
\hline Ethane & 0 & 0 & 0 & 0 & 0 & 0 & 0 & 0 & 1948.7582 & 194.8761 & 194.8761 & 194.8761 & 37.2409 & 36.8685 \\
\hline Propane & 0 & 0 & 0 & 0 & 0 & 0 & 0 & 0 & 0 & 0 & 0 & 0 & 0 & 0 \\
\hline Water & 9179.9326 & 9179.9326 & 0 & 0 & 0 & 0 & 8016.8018 & 8016.8037 & 62887.3594 & 41792.2578 & \begin{tabular}{|l|}
41792.2578 \\
\end{tabular} & 41792.2578 & 8559217 & 8473625 \\
\hline Sulphur & 0 & 0 & 0 & 0 & 3.0449 & 3.0449 & 0.0002 & 0.0002 & $\begin{array}{r}0 \\
\end{array}$ & 0 & \begin{tabular}{|r|}
0 \\
\end{tabular} & 0 & 0 & 0 \\
\hline Carbonyl Sulfide & 0 & 0 & 0 & 0 & 0 & 0 & 0 & 0 & 0 & 0 & 0 & 0 & 0 & 0 \\
\hline Hydrogen Sulfide & 0 & 0 & 0 & 0 & 0 & 0 & 0 & 0 & 35.064 & 35.064 & 35.064 & 35.064 & 24.5355 & 24.2902 \\
\hline Ammonia & 0 & 0 & 0 & 0 & 0 & 0 & 0 & 0 & 1312.5869 & 393.7765 & 393.7765 & 393.7765 & 31956.9629 & 31637.3926 \\
\hline HydrogenChloride & 0 & 0 & 0 & 0 & 0 & 0 & 0 & 0 & 18.5295 & 18.5296 & 18.5296 & 18.5296 & 1852.9353 & 1834.4059 \\
\hline Calcium Oxide & $\overline{0}$ & 4960.4048 & 0 & 0 & 0 & 0 & 0 & $\overline{0}$ & 0 & 0 & 0 & 0 & 0 & 0 \\
\hline Benzene & 0 & 0 & 0 & 0 & 0 & 0 & 0 & 0 & 8488.3174 & 2546.499 & 2546.499 & 2546.499 & 3839.2632 & 3800.8706 \\
\hline Naphthalene & 0 & 0 & 0 & 0 & 0 & 0 & 0 & 0 & 3977.6001 & 198.8803 & 198.8803 & 198.8803 & 1239.5193 & 1227.1241 \\
\hline Hybrid Poplar Ch & 0 & 0 & 0 & 0 & 0 & 0 & 0 & 0 & 0 & 0 & 0 & 0 & 0 & 0 \\
\hline \begin{tabular}{|l|} 
Sulfur Dioxide \\
\end{tabular} & 0 & 0 & 0 & 0 & 0 & 0 & 6.0849 & 6.0849 & 0 & 0 & 0 & 0 & 0 & 0 \\
\hline Hydrogen Cyanide & 0 & 0 & 0 & 0 & 0 & 0 & 0 & 0 & 0 & 0 & 0 & 0 & 0 & 0 \\
\hline Nitric Oxide & 0 & 0 & 0 & 0 & 0 & 0 & 783.8491 & 783.8492 & 0 & 0 & 0 & 0 & 0 & 0 \\
\hline Methanol & 0 & 0 & 0 & 0 & 0 & 0 & 0 & 0 & 0 & 0 & 0 & 0 & 0 & 0 \\
\hline Ethanol & 0 & 0 & 0 & 0 & 0 & 0 & 0 & 0 & 0 & 0 & 0 & 0 & 0 & 0 \\
\hline Isopropanol & 0 & 0 & 0 & 0 & 0 & 0 & 0 & 0 & 0 & 0 & 0 & 0 & 0 & 0 \\
\hline N-Propanol & 0 & 0 & 0 & 0 & 0 & 0 & 0 & 0 & 0 & 0 & 0 & 0 & 0 & 0 \\
\hline Isobutanol & 0 & 0 & 0 & 0 & 0 & 0 & 0 & 0 & 0 & 0 & 0 & 0 & 0 & 0 \\
\hline N-Butanol & 0 & 0 & 0 & 0 & 0 & 0 & 0 & 0 & 0 & 0 & 0 & 0 & 0 & 0 \\
\hline 1-Pentanol & 0 & 0 & 0 & 0 & 0 & 0 & 0 & 0 & 0 & 0 & 0 & 0 & 0 & $\overline{0}$ \\
\hline
\end{tabular}


Table B.2. (contd)

\begin{tabular}{|c|c|c|c|c|c|c|c|c|c|c|c|c|c|c|}
\hline Stream No. & 342 & 343 & 344 & 380 & 425 & 426 & 427 & 428 & 429 & 430 & 431 & 432 & 433 & 434 \\
\hline Temp F & 110 & 110 & 110.0031 & 116.4856 & 188.2762 & 140 & 105 & 105 & 105 & 120 & 120 & 120 & 707.0002 & 707.0002 \\
\hline Pres psia & 324 & 440 & 324 & 324 & 465 & 464 & 464 & 464 & 464 & 464 & 445 & 445 & 445 & 440 \\
\hline Enth MMBtu/h & -57765 & -305.68 & -58070 & -697.49 & -691.09 & $\begin{array}{l}-695.62 \\
\end{array}$ & -699.61 & -4.4756 & -695.13 & \begin{tabular}{|l|}
-693.74 \\
\end{tabular} & 0 & -693.69 & -636.28 & -0.0035631 \\
\hline Vapor mass fraction & 0.0031985 & 0 & 0.0031665 & 1 & 1 & 1 & 0.99662 & 0 & 1 & 1 & 0 & 1 & 1 & 1 \\
\hline Total lb/h & 8553097 & 45000 & 8598097 & 249032.25 & 249032.266 & 249032.266 & \begin{tabular}{|l|}
249032.266 \\
\end{tabular} & 841.976 & \begin{tabular}{|l|}
248190.281 \\
\end{tabular} & 248190.281 & 0 & 248190.281 & \begin{tabular}{|l|}
248190.297 \\
\end{tabular} & 34.8118 \\
\hline Flowrates in $1 \mathrm{~b} / \mathrm{h}$ & & & & & & & & & & & & & & \\
\hline Oxygen & 0 & 0 & 0 & 0 & 0 & 0 & 0 & 0 & 0 & 0 & 0 & 0 & 0 & 0 \\
\hline Nitrogen & 5.369 & 0 & 5.369 & 838.4609 & 838.4611 & 838.4611 & 838.4611 & 0.0022 & 838.4589 & 838.4589 & 0 & 838.4589 & 838.4589 & 0 \\
\hline Argon & 2.8234 & 0 & 2.8234 & 154.1096 & 154.1096 & 154.1096 & 154.1096 & 0.001 & 154.1086 & 154.1086 & 0 & 154.1086 & 154.1086 & 0 \\
\hline Carbon & 0 & 0 & 0 & 0 & 0 & 0 & 0 & 0 & 0 & 0 & 0 & 0 & 0 & 0 \\
\hline Hydrogen & 103.747 & 0 & 103.747 & 8375.2607 & 8375.2617 & 8375.2617 & 8375.2617 & 0.0098 & 8375.252 & 8375.252 & 0 & 8375.252 & 8375.252 & 0 \\
\hline Carbon Monoxide & 1118.1825 & 0 & 1118.1825 & 82524.4297 & 82524.4766 & 82524.4766 & \begin{tabular}{|l|}
82524.4766 \\
\end{tabular} & 0.2315 & \begin{tabular}{|l|}
82524.2344 \\
\end{tabular} & \begin{tabular}{|l|}
82524.2344 \\
\end{tabular} & 0 & 82524.2344 & 82524.2266 & 0 \\
\hline Carbon Dioxide & 39287.8047 & 0 & 39287.8086 & 135356 & \begin{tabular}{|l|}
135356 \\
\end{tabular} & 135356 & \begin{tabular}{|l|}
135356 \\
\end{tabular} & 8.6833 & \begin{tabular}{|l|}
135347.188 \\
\end{tabular} & \begin{tabular}{|l|}
135347.188 \\
\end{tabular} & 0 & 135347.188 & 135347.203 & 0 \\
\hline Methane & 278.0774 & 0 & 278.0774 & \begin{tabular}{|l|}
17066.7441 \\
\end{tabular} & 17066.748 & 17066.748 & 17066.748 & 0.1913 & 17066.5527 & 17066.5527 & 0 & 17066.5527 & 17066.5508 & $\overline{0}$ \\
\hline Acetylene & 0 & 0 & 0 & \begin{tabular}{|l|}
0 \\
\end{tabular} & 0 & 0 & 0 & 0 & \begin{tabular}{|l|}
0 \\
\end{tabular} & $\begin{array}{ll}0 \\
\end{array}$ & 0 & 0 & \begin{tabular}{|l|}
0 \\
\end{tabular} & 0 \\
\hline Ethylene & 116.0277 & 0 & 116.0277 & 519.4758 & 519.4761 & 519.4761 & 519.4761 & 0.0251 & 519.451 & 519.451 & 0 & 519.451 & 519.451 & 0 \\
\hline Ethane & 36.8685 & 0 & 36.8685 & 194.5036 & 194.5037 & 194.5037 & 194.5037 & 0.0135 & 194.4902 & 194.4902 & 0 & 194.4902 & 194.4902 & 0 \\
\hline Propane & 0 & 0 & 0 & 0 & $\begin{array}{r}0 \\
\end{array}$ & 0 & 0 & 0 & 0 & 0 & 0 & 0 & 0 & 0 \\
\hline Water & 8473625 & 45000 & 8518625 & 1199.7528 & 1199.7526 & 1199.7526 & 1199.7526 & 661.3782 & 538.381 & 538.381 & 0 & 538.381 & 538.381 & 0 \\
\hline Sulphur & $\begin{array}{r}0 \\
\end{array}$ & 0 & 0 & 0 & 0 & 0 & 0 & 0 & 0 & 0 & 0 & 0 & 0 & 0 \\
\hline Carbonyl Sulfide & 0 & 0 & 0 & 0 & 0 & 0 & 0 & 0 & 0 & 0 & 0 & 0 & 0 & 0 \\
\hline Hydrogen Sulfide & 24.2902 & 0 & 24.2902 & 34.8187 & 34.8187 & 34.8187 & 34.8187 & 0.0069 & 34.8118 & 34.8118 & 0 & 34.8118 & 34.8118 & 34.8118 \\
\hline Ammonia & 31637.3926 & 0 & 31637.3945 & 74.2077 & 74.2077 & 74.2077 & 74.2077 & 0.0236 & 74.1841 & 74.1841 & 0 & 74.1841 & 74.1841 & 0 \\
\hline HydrogenChloride & 1834.4059 & 0 & 1834.4059 & 0 & 0 & 0 & 0 & 0 & 0 & 0 & 0 & 0 & 0 & 0 \\
\hline Calcium Oxide & 0 & 0 & 0 & 0 & 0 & 0 & 0 & 0 & 0 & 0 & 0 & 0 & 0 & $\overline{0}$ \\
\hline Benzene & 3800.8706 & 0 & 3800.8706 & 2508.1113 & 2508.1118 & 2508.1118 & 2508.1118 & 34.8027 & 2473.3093 & 2473.3093 & 0 & 2473.3093 & 2473.3091 & 0 \\
\hline Naphthalene & 1227.1241 & 0 & 1227.1241 & 186.4863 & 186.4864 & 186.4864 & 186.4864 & 136.6067 & 49.881 & 49.881 & 0 & 49.881 & 49.8811 & 0 \\
\hline Hybrid Poplar Ch & $\begin{array}{r}0 \\
\end{array}$ & 0 & 0 & 0 & $\begin{array}{r}0 \\
\end{array}$ & 0 & $\begin{array}{r}0 \\
\end{array}$ & 0 & 0 & 0 & 0 & 0 & 0 & 0 \\
\hline Sulfur Dioxide & 0 & 0 & 0 & 0 & 0 & 0 & 0 & 0 & 0 & 0 & 0 & 0 & 0 & 0 \\
\hline Hydrogen Cyanide & 0 & 0 & 0 & 0 & 0 & 0 & 0 & 0 & 0 & 0 & 0 & 0 & 0 & 0 \\
\hline Nitric Oxide & 0 & 0 & 0 & 0 & 0 & 0 & 0 & 0 & 0 & 0 & 0 & 0 & 0 & 0 \\
\hline Methanol & 0 & 0 & 0 & 0 & 0 & 0 & 0 & 0 & 0 & 0 & 0 & 0 & 0 & 0 \\
\hline Ethanol & 0 & 0 & 0 & 0 & 0 & 0 & 0 & 0 & 0 & 0 & 0 & 0 & 0 & 0 \\
\hline Isopropanol & 0 & 0 & 0 & 0 & 0 & 0 & 0 & 0 & 0 & 0 & 0 & 0 & 0 & 0 \\
\hline N-Propanol & 0 & 0 & 0 & 0 & 0 & 0 & 0 & 0 & 0 & 0 & 0 & 0 & 0 & 0 \\
\hline Isobutanol & 0 & 0 & 0 & 0 & 0 & 0 & 0 & 0 & 0 & 0 & 0 & 0 & 0 & 0 \\
\hline N-Butanol & 0 & 0 & 0 & 0 & 0 & 0 & 0 & 0 & 0 & 0 & 0 & 0 & 0 & 0 \\
\hline 1-Pentanol & 0 & 0 & 0 & 0 & 0 & 0 & 0 & 0 & 0 & 0 & 0 & 0 & 0 & 0 \\
\hline
\end{tabular}


Table B.2. ( contd)

\begin{tabular}{|c|c|c|c|c|c|c|c|c|c|c|c|c|c|c|}
\hline Stream No. & 435 & 440 & 441 & 443 & 445 & 446 & 447 & 448 & 449 & 450 & 451 & 452 & 453 & 471 \\
\hline Temp F & 707.0002 & 700.6349 & 975 & 1652 & 1345.5765 & 1181.9598 & 300.0202 & 150 & 110 & 110 & 120 & 120 & 58.5657 & 275.956 \\
\hline Pres psia & 440 & 440 & 435 & 420 & 419 & 419 & 419 & 419 & 416.5 & 416.5 & 411.5 & 411.5 & 22 & 800 \\
\hline Enth MMBtu/h & -636.28 & -966.46 & -929.12 & -757.04 & -802.88 & -826.65 & -962.47 & $\mid-1024.3$ & -1032.1 & $\begin{array}{l}-619.96 \\
\end{array}$ & -231.7 & -388.41 & $\mid-388.41$ & -220 \\
\hline Vapor mass fraction & 1 & 1 & 1 & 1 & 1 & 1 & 0.94339 & 0.80767 & 0.80312 & 1 & 1 & 0.99413 & 0.99693 & 1 \\
\hline Total lb/h & 248155.406 & \begin{tabular}{|l|}
308155.469 \\
\end{tabular} & 308155.469 & 308155 & 308155 & 308155 & 308155 & 308155 & 308155 & 247485 & \begin{tabular}{|l|}
147032.703 \\
\end{tabular} & 100452.055 & \begin{tabular}{|l|}
100452.039 \\
\end{tabular} & 147032.734 \\
\hline \multicolumn{15}{|l|}{ Flowrates in $\mathrm{lb} / \mathrm{h}$} \\
\hline Oxygen & 0 & 0 & 0 & 0 & 0 & 0 & 0 & 0 & 0 & 0 & 0 & 0 & 0 & 0 \\
\hline Nitrogen & 838.4583 & 838.4589 & 838.4589 & 886.7114 & 886.7114 & 886.7114 & 886.7114 & 886.7114 & 886.7114 & 886.7114 & 886.7114 & 0 & 0 & 886.7114 \\
\hline Argon & 154.1085 & 154.1086 & 154.1086 & 154.1086 & 154.1086 & 154.1086 & 154.1086 & 154.1086 & 154.1086 & 154.1086 & 154.1086 & 0 & 0 & 154.1086 \\
\hline Carbon & 0 & 0 & 0 & 0 & 0 & 0 & 0 & 0 & 0 & 0 & 0 & 0 & 0 & 0 \\
\hline Hydrogen & 8375.249 & 8375.252 & 8375.252 & 10583.9385 & 10583.9375 & 10583.9375 & 10583.9375 & 10583.9375 & 10583.9404 & 10583.9365 & 10583.9404 & 0 & 0 & 10583.9365 \\
\hline Carbon Monoxide & 82524.1953 & 82524.2344 & \begin{tabular}{|l|}
82524.2344 \\
\end{tabular} & 125239.344 & 125239.344 & \begin{tabular}{|l|}
125239.344 \\
\end{tabular} & 125239.344 & 125239.344 & 125239.305 & 125239.344 & 125239.305 & 0 & 0 & 125239.344 \\
\hline Carbon Dioxide & 135347.156 & 135347.188 & 135347.188 & 100691.008 & 100691 & 100691 & 100691 & 100691 & 100691 & 100691 & \begin{tabular}{|l|}
1006.911 \\
\end{tabular} & 99684.0781 & 99684.0625 & 1006.9114 \\
\hline Methane & 17066.5488 & 17066.5527 & 17066.5527 & 9144.5645 & 9144.5645 & 9144.5645 & 9144.5645 & 9144.5645 & 9144.5645 & 9144.5645 & 9144.5645 & 0 & 0 & 9144.5645 \\
\hline Acetylene & 0 & $\begin{array}{r}0 \\
\end{array}$ & $\begin{array}{r}0 \\
\end{array}$ & 0 & 0 & 0 & 0 & 0 & 0 & 0 & 0 & 0 & 0 & 0 \\
\hline \begin{tabular}{|l|} 
Ethylene \\
\end{tabular} & 519.4506 & 519.451 & 519.451 & 0.4541 & 0.4541 & 0.4541 & 0.4541 & 0.4541 & 0.4541 & 0.4541 & 0.4541 & 0 & 0 & 0.4541 \\
\hline Ethane & 194.4901 & 194.4902 & 194.4902 & 1.0472 & 1.0472 & 1.0472 & 1.0472 & 1.0472 & 1.0472 & 1.0472 & 1.0472 & 0 & 0 & 1.0472 \\
\hline Propane & 0 & 0 & 0 & 0 & 0 & 0 & 0 & 0 & 0 & 0 & 0 & 0 & 0 & 0 \\
\hline Water & 538.3807 & 60538.3789 & 60538.3789 & 61438 & 61438 & 61438 & 61438 & 61438 & 61438 & 767.9789 & 0 & 767.9789 & 767.9795 & 0 \\
\hline Sulphur & 0 & \begin{tabular}{|r|}
0 \\
\end{tabular} & \begin{tabular}{|l}
0 \\
\end{tabular} & 0 & 0 & 0 & 0 & 0 & 0 & 0 & 0 & 0 & 0 & $\overline{0}$ \\
\hline Carbonyl Sulfide & 0 & 0 & 0 & 0 & 0 & 0 & 0 & 0 & 0 & 0 & 0 & 0 & 0 & 0 \\
\hline Hydrogen Sulfide & 0 & 0 & 0 & 0 & 0 & 0 & 0 & 0 & 0 & 0 & 0 & 0 & 0 & 0 \\
\hline Ammonia & 74.184 & 74.1841 & 74.1841 & 15.3483 & 15.3483 & 15.3483 & 15.3483 & 15.3483 & 15.3483 & 15.3483 & 15.3483 & 0 & 0 & 15.3483 \\
\hline HydrogenChloride & 0 & 0 & 0 & 0 & 0 & 0 & 0 & 0 & 0 & 0 & 0 & 0 & 0 & 0 \\
\hline Calcium Oxide & 0 & 0 & 0 & 0 & 0 & 0 & 0 & $\overline{0}$ & 0 & 0 & $\overline{0}$ & 0 & 0 & $\overline{0}$ \\
\hline Benzene & 2473.3081 & 2473.3093 & 2473.3093 & 0 & 0 & 0 & 0 & 0 & 0 & 0 & 0 & 0 & 0 & $\overline{0}$ \\
\hline Naphthalene & 49.881 & 49.881 & 49.881 & 0 & 0 & 0 & 0 & 0 & 0 & 0 & 0 & 0 & 0 & 0 \\
\hline Hybrid Poplar Ch & 0 & 0 & 0 & 0 & 0 & 0 & 0 & 0 & 0 & 0 & 0 & 0 & 0 & 0 \\
\hline Sulfur Dioxide & 0 & 0 & 0 & 0 & 0 & 0 & 0 & 0 & 0 & 0 & 0 & 0 & 0 & 0 \\
\hline Hydrogen Cyanide & 0 & 0 & 0 & 0.2669 & 0.2669 & 0.2669 & 0.2669 & 0.2669 & 0.2669 & 0.2669 & 0.2669 & 0 & 0 & 0.2669 \\
\hline Nitric Oxide & 0 & 0 & 0 & 0 & 0 & 0 & 0 & 0 & 0 & 0 & 0 & 0 & 0 & 0 \\
\hline Methanol & 0 & 0 & 0 & 0.0662 & 0.0662 & 0.0662 & 0.0662 & 0.0662 & 0.0662 & 0.0662 & 0.0662 & 0 & 0 & 0.0662 \\
\hline Ethanol & 0 & 0 & 0 & 0 & 0 & 0 & 0 & 0 & 0 & 0 & 0 & 0 & 0 & 0 \\
\hline Isopropanol & 0 & 0 & 0 & 0 & 0 & 0 & 0 & 0 & 0 & 0 & 0 & 0 & 0 & 0 \\
\hline N-Propanol & 0 & 0 & 0 & 0 & 0 & 0 & 0 & 0 & 0 & 0 & 0 & 0 & 0 & 0 \\
\hline Isobutanol & 0 & 0 & 0 & 0 & 0 & 0 & 0 & 0 & 0 & 0 & 0 & 0 & 0 & 0 \\
\hline N-Butanol & 0 & 0 & 0 & 0 & 0 & 0 & 0 & 0 & 0 & 0 & 0 & 0 & 0 & 0 \\
\hline 1-Pentanol & 0 & 0 & 0 & 0 & 0 & 0 & 0 & 0 & 0 & 0 & 0 & 0 & 0 & 0 \\
\hline
\end{tabular}


Table B.2. (contd)

\begin{tabular}{|c|c|c|c|c|c|c|c|c|c|c|c|c|c|c|}
\hline Stream No. & 472 & 473 & 474 & 475 & 490 & 491 & 493 & 494 & 495 & 496 & 497 & 498 & 499 & 510 \\
\hline Temp F & 140 & 233.8242 & 140 & 259.9529 & 60 & 124.5558 & 110.0473 & 1800 & 1800 & 1350.5909 & 951.462 & 274.1718 & 311.9207 & 400 \\
\hline Pres psia & 800 & 1200 & 1200 & 2000 & 14.696 & 20 & 16 & 16 & 16 & 15 & 14 & 13 & 15 & 1995 \\
\hline Enth MMBtu/h & -230.27 & -223.14 & -230.31 & -220.98 & -1.2011 & 3.2632 & -48.925 & -221.42 & -221.42 & -265.57 & -302.91 & -361.71 & -358.57 & -1135.8 \\
\hline Vapor mass fraction & 1 & 1 & 1 & 1 & 1 & 1 & 1 & 1 & 1 & 1 & 1 & 1 & 1 & 1 \\
\hline Total lb/h & 147032.734 & 147032.734 & 147032.734 & \begin{tabular}{|l|}
147032.703 \\
\end{tabular} & 286107.344 & 286107.344 & 310052.375 & 310052 & 310052 & 310052 & 310052 & 310052 & 310052 & 716823 \\
\hline Flowrates in $\mathrm{lb} / \mathrm{h}$ & & & & & & & & & & & & & & \\
\hline \begin{tabular}{|l|} 
Oxygen \\
\end{tabular} & 0 & 0 & 0 & 0 & \begin{tabular}{|l|}
66638.8594 \\
\end{tabular} & 66638.8594 & 66638.8594 & 8146.0688 & 8146.0688 & 8146.0688 & 8145.9722 & 8145.9722 & 8145.9731 & 0 \\
\hline Nitrogen & 886.7114 & 886.7114 & 886.7114 & 886.7112 & 219468.469 & 219468.469 & 220115 & 220108.563 & 220108.563 & 220108.563 & 220108.563 & 220108.594 & 220108.594 & 21820.1797 \\
\hline Argon & 154.1086 & 154.1086 & 154.1086 & 154.1086 & $\begin{array}{r}0 \\
\end{array}$ & \begin{tabular}{|l|}
0 \\
\end{tabular} & 112.3462 & 112.3462 & 112.3462 & 112.3462 & 112.3462 & \begin{tabular}{|l|}
112.3462 \\
\end{tabular} & 112.3462 & \begin{tabular}{|l|}
3592.5518 \\
\end{tabular} \\
\hline Carbon & 0 & 0 & 0 & 0 & 0 & 0 & 0 & 0 & 0 & 0 & 0 & 0 & 0 & 0 \\
\hline Hydrogen & 10583.9365 & 10583.9365 & 10583.9365 & 10583.9336 & 0 & 0 & 303.6196 & 0.0009 & 0.0009 & 0.0009 & 0.0009 & 0.0009 & 0.0009 & 20416.5176 \\
\hline Carbon Monoxide & 125239.344 & 125239.344 & 125239.344 & 125239.32 & 0 & 0 & 4827.6704 & 0.0121 & 0.0121 & 0.0121 & 0.0121 & 0.0121 & 0.0121 & 280155.375 \\
\hline Carbon Dioxide & 1006.9114 & 1006.9114 & 1006.9114 & 1006.9109 & 0 & 0 & 3239.5835 & 48511.5234 & 48511.5234 & 48511.5234 & 48511.5391 & 48511.5391 & 48511.5586 & 1550.192 \\
\hline Methane & 9144.5645 & 9144.5645 & 9144.5645 & 9144.5635 & 0 & 0 & 11930.1758 & 0.0002 & 0.0002 & 0.0002 & 0.0002 & 0.0002 & 0.0002 & 367524.344 \\
\hline Acetylene & 0 & 0 & 0 & 0 & 0 & 0 & 0 & 0 & 0 & 0 & 0 & 0 & 0 & 0 \\
\hline Ethylene & 0.4541 & 0.4541 & 0.4541 & 0.4541 & 0 & 0 & 0.331 & 0.0003 & 0.0003 & 0.0003 & 0.0003 & 0.0003 & 0.0003 & 8.4128 \\
\hline Ethane & 1.0472 & 1.0472 & 1.0472 & 1.0472 & 0 & 0 & 548.7436 & 0.0003 & 0.0003 & 0.0003 & 0.0003 & 0.0003 & 0.0003 & 12438.6396 \\
\hline Propane & 0 & 0 & 0 & 0 & 0 & 0 & 0 & 0 & 0 & 0 & 0 & 0 & 0 & $\begin{array}{r}0 \\
\end{array}$ \\
\hline Water & 0 & 0 & 0 & 0 & 0 & 0 & 95.2335 & 33139.5938 & 33139.5938 & 33139.5938 & 33139.6797 & 33139.6797 & 33139.6719 & 0 \\
\hline Sulphur & 0 & 0 & 0 & 0 & 0 & 0 & 0 & 0 & 0 & 0 & 0 & 0 & 0 & 0 \\
\hline Carbonyl Sulfide & 0 & 0 & 0 & 0 & 0 & 0 & 0 & 0 & 0 & 0 & 0 & 0 & 0 & 0 \\
\hline Hydrogen Sulfide & 0 & 0 & 0 & 0 & 0 & 0 & 0 & 0 & 0 & 0 & 0 & 0 & 0 & 0 \\
\hline Ammonia & 15.3483 & 15.3483 & 15.3483 & 15.3482 & 0 & 0 & 11.1828 & 0.0002 & 0.0002 & 0.0002 & 0.0002 & 0.0002 & 0.0002 & 67.9379 \\
\hline HydrogenChloride & 0 & 0 & 0 & 0 & 0 & 0 & 0 & 0 & 0 & 0 & 0 & 0 & 0 & 0 \\
\hline Calcium Oxide & 0 & 0 & 0 & 0 & $\overline{0}$ & 0 & 0 & 0 & 0 & 0 & 0 & 0 & 0 & 0 \\
\hline Benzene & 0 & 0 & 0 & 0 & 0 & 0 & 0 & 0 & 0 & 0 & 0 & 0 & 0 & 0 \\
\hline Naphthalene & 0 & 0 & 0 & 0 & 0 & 0 & 0 & 0 & 0 & 0 & 0 & 0 & 0 & $\overline{0}$ \\
\hline Hybrid Poplar Ch & 0 & 0 & 0 & 0 & 0 & 0 & 0 & 0 & 0 & 0 & 0 & 0 & 0 & 0 \\
\hline \begin{tabular}{|l|} 
Sulfur Dioxide \\
\end{tabular} & 0 & 0 & 0 & 0 & 0 & 0 & 0 & 0 & 0 & 0 & 0 & 0 & 0 & 0 \\
\hline Hydrogen Cyanide & 0.2669 & 0.2669 & 0.2669 & 0.2669 & 0 & 0 & 0.1945 & 0.0003 & 0.0003 & 0.0003 & 0.0003 & 0.0003 & 0.0003 & 0.6524 \\
\hline Nitric Oxide & 0 & 0 & 0 & 0 & 0 & 0 & 0 & 33.6758 & 33.6758 & 33.6758 & 33.6756 & 33.6756 & 33.6755 & 0 \\
\hline Methanol & 0.0662 & 0.0662 & 0.0662 & 0.0662 & 0 & 0 & 1726.9731 & 0.0003 & 0.0003 & 0.0003 & 0.0003 & 0.0003 & 0.0003 & 2631.7458 \\
\hline \begin{tabular}{|l|} 
Ethanol \\
\end{tabular} & 0 & 0 & 0 & 0 & 0 & 0 & 445.799 & 0.0005 & 0.0005 & 0.0005 & 0.0005 & 0.0005 & 0.0005 & 5707.2822 \\
\hline Isopropanol & 0 & 0 & 0 & 0 & 0 & 0 & 0 & 0 & 0 & 0 & 0 & 0 & 0 & 0 \\
\hline N-Propanol & 0 & 0 & 0 & 0 & 0 & 0 & 43.4006 & 0.0006 & 0.0006 & 0.0006 & 0.0006 & 0.0006 & 0.0006 & 668.366 \\
\hline Isobutanol & 0 & 0 & 0 & 0 & 0 & 0 & 0 & 0 & 0 & 0 & 0 & 0 & 0 & 0 \\
\hline N-Butanol & 0 & 0 & 0 & 0 & 0 & 0 & 9.0992 & 0.0007 & 0.0007 & 0.0007 & 0.0007 & 0.0007 & 0.0007 & 160.3787 \\
\hline 1-Pentanol & 0 & 0 & 0 & 0 & 0 & 0 & 4.1408 & 0.0007 & 0.0007 & 0.0007 & 0.0007 & 0.0007 & 0.0007 & 79.7522 \\
\hline
\end{tabular}


Table B.2. (contd)

\begin{tabular}{|c|c|c|c|c|c|c|c|c|c|c|c|c|c|c|}
\hline Stream No. & 512 & 516 & 517 & 518 & 519 & 520 & 521 & 523 & 524 & 525 & 528 & 530 & 551 & 552 \\
\hline Temp F & 398.5988 & 570 & 570.0002 & 332.9341 & 125 & 110 & 109.987 & 108.9517 & 108.9517 & 110.0237 & 110.0237 & 110.0237 & 108.9517 & 108.9517 \\
\hline Pres psia & 1995 & 1995 & 1995 & 1990 & 1980 & 1975 & 1974 & 1974 & 1974 & 35 & 35 & 35 & 1974 & 1974 \\
\hline Enth MMBtu/h & -1168.6 & -1306 & -1306 & -1410.6 & -1524.6 & -1533 & -1533 & -1292.3 & -240.72 & -240.72 & -228.73 & -11.991 & -51.692 & -1240.6 \\
\hline Vapor mass fraction & 1 & 1 & & 1 & 0.90085 & 0.89408 & 0.89407 & 1 & 0 & 0.054273 & 0 & 1 & 1 & 1 \\
\hline Total lb/h & 729095 & 729097.25 & 729097.125 & 729107 & 729107 & 729107 & 729107 & 650565 & 78542 & 78542 & \begin{tabular}{|l|}
74279.2891 \\
\end{tabular} & 4262.6914 & 26022.5918 & 624542.188 \\
\hline Flowrates in $1 \mathrm{~b} / \mathrm{h}$ & & & & & & & & & & & & & & \\
\hline Oxygen & 0 & 0 & 0 & 0 & 0 & 0 & 0 & 0 & 0 & 0 & 0 & 0 & 0 & 0 \\
\hline Nitrogen & 21820.1738 & 21820.1797 & 21820.1777 & 21820.8398 & 21820.8398 & 21820.8398 & 21820.8398 & 21805.6895 & 15.1514 & 15.1515 & 0.0347 & 15.1167 & 872.2275 & 20933.4609 \\
\hline Argon & 3592.5518 & 3592.5518 & 3592.5505 & 3592.6443 & 3592.6443 & 3592.6443 & 3592.6438 & 3581.7087 & 10.9357 & 10.9358 & 0.1288 & 10.807 & 143.2683 & 3438.4404 \\
\hline Carbon & 0 & 0 & 0 & 0 & 0 & 0 & 0 & 0 & 0 & 0 & 0 & 0 & 0 & 0 \\
\hline Hydrogen & 20416.5176 & 10249.5361 & 10249.5352 & 10249.0889 & 10249.0889 & 10249.0889 & 10249.0898 & 10242.0273 & 7.0609 & 7.0609 & 0.0147 & 7.0462 & 409.6811 & 9832.3457 \\
\hline Carbon Monoxide & 280155.313 & 161542.484 & 161542.406 & 161542.328 & 161542.328 & 161542.328 & 161542.297 & \begin{tabular}{|l|}
161370.813 \\
\end{tabular} & 171.5301 & 171.5301 & 0.6415 & 170.8886 & 6454.832 & 154916 \\
\hline Carbon Dioxide & 1550.1919 & \begin{tabular}{|l|}
58774.5 \\
\end{tabular} & 58774.4844 & 58774.4492 & 58774.4492 & \begin{tabular}{|l|}
58774.4492 \\
\end{tabular} & 58774.4492 & 56591.5234 & 2182.9258 & 2182.926 & 408.497 & 1774.4286 & 2263.6609 & 54327.8594 \\
\hline Methane & 367524.313 & 374745.125 & 374745.094 & 374754.25 & 374754.25 & 374754.25 & 374754.313 & 373311.625 & 1442.6525 & 1442.652 & 24.0583 & 1418.594 & 14932.4648 & 358379.156 \\
\hline Acetylene & 0 & \begin{tabular}{r|}
0 \\
\end{tabular} & 0 & 0 & 0 & 0 & \begin{tabular}{|l|}
0 \\
\end{tabular} & \begin{tabular}{|l|}
0 \\
\end{tabular} & 0 & 0 & 0 & 0 & \begin{tabular}{|l|}
0 \\
\end{tabular} & 0 \\
\hline \begin{tabular}{|l|} 
Ethylene \\
\end{tabular} & 8.4128 & 8.4128 & 8.4128 & 8.4129 & 8.4129 & 8.4129 & 8.4129 & 8.2902 & 0.1227 & 0.1227 & 0.01 & 0.1127 & 0.3316 & 7.9586 \\
\hline Ethane & 12438.6387 & 13190.5381 & 13190.542 & 13190.7422 & 13190.7422 & 13190.7422 & 13190.7402 & 12955.7793 & 234.9632 & 234.9632 & 24.8815 & 210.0817 & 518.2311 & 12437.5488 \\
\hline Propane & 0 & 0 & 0 & 0 & 0 & 0 & 0 & 0 & 0 & 0 & 0 & 0 & 0 & 0 \\
\hline Water & 0 & 9348.4795 & 9348.4805 & 9348.4941 & 9348.4941 & 9348.4941 & 9348.4932 & 1009.5903 & 8338.8994 & 8338.8994 & 8248.7803 & 90.1194 & 40.3836 & 969.2066 \\
\hline Sulphur & 0 & 0 & 0 & 0 & 0 & 0 & 0 & 0 & 0 & 0 & 0 & 0 & 0 & 0 \\
\hline Carbonyl Sulfide & 0 & 0 & 0 & 0 & 0 & 0 & 0 & 0 & 0 & 0 & 0 & 0 & 0 & 0 \\
\hline Hydrogen Sulfide & 0 & 0 & 0 & 0 & 0 & 0 & 0 & 0 & 0 & 0 & 0 & 0 & 0 & 0 \\
\hline Ammonia & 67.9379 & 67.9379 & 67.9379 & 67.9386 & 67.9386 & 67.9386 & 67.9386 & 54.7806 & 13.158 & 13.158 & 8.4246 & 4.7334 & 2.1912 & 52.5894 \\
\hline HydrogenChloride & 0 & 0 & 0 & 0 & 0 & 0 & 0 & 0 & 0 & 0 & 0 & 0 & 0 & 0 \\
\hline Calcium Oxide & 0 & 0 & 0 & 0 & 0 & 0 & 0 & 0 & 0 & 0 & 0 & 0 & 0 & 0 \\
\hline Benzene & 0 & 0 & 0 & 0 & 0 & 0 & 0 & 0 & 0 & 0 & 0 & 0 & 0 & 0 \\
\hline Naphthalene & 0 & 0 & 0 & 0 & 0 & 0 & 0 & 0 & 0 & 0 & 0 & 0 & 0 & 0 \\
\hline Hybrid Poplar Ch & 0 & 0 & 0 & 0 & 0 & 0 & 0 & 0 & 0 & 0 & 0 & 0 & 0 & 0 \\
\hline Sulfur Dioxide & 0 & 0 & 0 & 0 & 0 & 0 & 0 & 0 & 0 & 0 & 0 & 0 & 0 & 0 \\
\hline Hydrogen Cyanide & 0.6524 & 0.6524 & 0.6524 & 0.6524 & 0.6524 & 0.6524 & 0.6524 & 0.4015 & 0.2509 & 0.2509 & 0.2227 & 0.0282 & 0.0161 & 0.3855 \\
\hline Nitric Oxide & 0 & 0 & 0 & 0 & 0 & 0 & 0 & 0 & 0 & 0 & 0 & 0 & 0 & 0 \\
\hline Methanol & 14869.9063 & 17377.7422 & 17377.7344 & 17377.7383 & 17377.7383 & \begin{tabular}{|l|}
17377.7383 \\
\end{tabular} & 17377.7402 & 2741.3027 & 14636.4287 & 14636.4297 & 14458.3926 & 178.0387 & 109.6521 & 2631.6504 \\
\hline Ethanol & 5741.4941 & 44406.1289 & 44406.1211 & 44406.2461 & 44406.2461 & 44406.2461 & 44406.25 & 5945.0063 & 38461.2227 & 38461.2188 & 38118.3906 & 342.8346 & 237.8003 & 5707.2061 \\
\hline Isopropanol & 0 & 0 & 0 & 0 & 0 & 0 & 0 & 0 & 0 & 0 & 0 & 0 & 0 & 0 \\
\hline N-Propanol & 668.6248 & 8631.6484 & 8631.6475 & 8631.6592 & 8631.6592 & 8631.6592 & 8631.6582 & 696.2037 & 7935.4526 & 7935.4531 & 7903.7603 & 31.6934 & 27.8481 & 668.3555 \\
\hline Isobutanol & 0 & 0 & 0 & 0 & 0 & 0 & 0 & 0 & 0 & 0 & 0 & 0 & 0 & 0 \\
\hline N-Butanol & 160.3787 & 3561.7605 & 3561.7603 & 3561.7659 & 3561.7659 & 3561.7659 & 3561.7661 & 167.0592 & 3394.7053 & 3394.7051 & 3388.8984 & 5.807 & 6.6824 & 160.3768 \\
\hline 1-Pentanol & 79.7522 & 1779.5919 & 1779.5916 & 1779.5946 & 1779.5946 & 1779.5946 & 1779.5941 & 83.0744 & 1696.5195 & 1696.52 & 1694.1589 & 2.3606 & 3.323 & 79.7514 \\
\hline
\end{tabular}


Table B.2. (contd)

\begin{tabular}{|c|c|c|c|c|c|c|c|c|c|c|c|c|c|c|}
\hline Stream No. & 553 & 554 & 555 & 556 & 559 & 560 & 561 & 601 & 605 & 606 & 610 & 611 & 612 & 620 \\
\hline Temp F & 230 & 63.3966 & 130 & 132.3299 & 152.5568 & 189.1794 & 550 & 149.5734 & 195.2473 & 194.8802 & 152.0194 & 152.0194 & 152.0194 & 197.9073 \\
\hline Pres psia & 1974 & 22 & 1974 & 2000 & 2000 & 2000 & 2000 & 23 & 26.7 & 26.6999 & 16 & 16 & 16 & 22 \\
\hline Enth MMBtu/h & -213.26 & -213.26 & -1020.1 & -1019.4 & -1240.4 & -38.617 & -32.758 & -3.6449 & -219.55 & -219.55 & -43.042 & -4.3042 & -38.738 & -121.36 \\
\hline Vapor mass fraction & 0.98797 & 0.98768 & & 1 & 1 & 0.0003125 & 1 & 1 & 0 & 0 & 0 & 0 & 0 & 0 \\
\hline Total lb/h & 54753.7891 & 54753.7891 & 569788.375 & 569789 & 716823 & \begin{tabular}{|l|}
12272.6377 \\
\end{tabular} & 12272.6377 & 1217.5072 & 73061.7813 & 73061.7813 & 13636.2656 & 1363.6266 & 12272.6416 & \begin{tabular}{|l|l|}
51176.9258 \\
\end{tabular} \\
\hline Flowrates in $\mathrm{lb} / \mathrm{h}$ & & & & & & & & & & & . & & . & \\
\hline Oxygen & 0 & 0 & 0 & 0 & 0 & 0 & 0 & 0 & 0 & 0 & 0 & 0 & 0 & 0 \\
\hline Nitrogen & 0 & 0 & 20933.4609 & 20933.4668 & 21820.1797 & 0 & 0 & 0.0347 & 0 & 0 & 0 & 0 & 0 & 0 \\
\hline Argon & 0 & 0 & 3438.4399 & \begin{tabular}{|l|}
3438.4412 \\
\end{tabular} & 3592.5518 & 0 & 0 & 0.1288 & 0 & 0 & 0 & 0 & 0 & 0 \\
\hline Carbon & 0 & 0 & 0 & 0 & 0 & 0 & 0 & 0 & 0 & 0 & 0 & 0 & 0 & 0 \\
\hline Hydrogen & 0 & 0 & 9832.3467 & 9832.3486 & 20416.5176 & 0 & 0 & 0.0147 & 0 & 0 & 0 & 0 & 0 & 0 \\
\hline Carbon Monoxide & 0 & 0 & 154916 & \begin{tabular}{|l|}
154916.016 \\
\end{tabular} & 280155.375 & 0 & 0 & 0.6415 & 0 & 0 & 0 & 0 & 0 & 0 \\
\hline Carbon Dioxide & 53784.582 & 53784.582 & 543.2805 & 543.2808 & 1550.192 & 0 & 0 & 408.497 & 0 & 0 & 0 & 0 & 0 & 0 \\
\hline Methane & 0 & 0 & 358379.094 & 358379.25 & 367524.344 & 0 & 0 & 24.0583 & 0 & 0 & 0 & 0 & 0 & 0 \\
\hline Acetylene & 0 & 0 & 0 & 0 & 0 & 0 & 0 & 0 & 0 & 0 & 0 & 0 & 0 & 0 \\
\hline Ethylene & 0 & 0 & 7.9586 & 7.9586 & 8.4128 & 0 & 0 & 0.01 & 0 & 0 & 0 & 0 & 0 & 0 \\
\hline Ethane & 0 & 0 & 12437.5498 & 12437.5518 & 12438.6396 & 0 & 0 & 24.8815 & 0 & 0 & 0 & 0 & 0 & 0 \\
\hline Propane & 0 & 0 & 0 & 0 & 0 & 0 & 0 & 0 & 0 & 0 & 0 & 0 & 0 & 0 \\
\hline Water & 969.2066 & 969.2065 & 0 & 0 & 0 & 0 & 0 & 0.2125 & 8248.5674 & 8248.5674 & 0 & 0 & 0 & 0 \\
\hline \begin{tabular}{|l|} 
Sulphur \\
\end{tabular} & 0 & 0 & 0 & 0 & 0 & 0 & 0 & 0 & 0 & 0 & 0 & 0 & 0 & $\overline{0}$ \\
\hline Carbonyl Sulfide & 0 & 0 & 0 & 0 & 0 & 0 & 0 & 0 & 0 & 0 & 0 & 0 & 0 & $\overline{0}$ \\
\hline Hydrogen Sulfide & 0 & 0 & 0 & 0 & 0 & 0 & 0 & 0 & 0 & 0 & 0 & 0 & 0 & 0 \\
\hline Ammonia & 0 & 0 & 52.5894 & 52.5894 & 67.9379 & 0 & 0 & 8.4246 & 0 & 0 & 0 & 0 & 0 & 0 \\
\hline HydrogenChloride & 0 & 0 & 0 & 0 & 0 & 0 & 0 & 0 & 0 & 0 & 0 & 0 & 0 & 0 \\
\hline Calcium Oxide & 0 & 0 & 0 & 0 & 0 & 0 & 0 & 0 & 0 & 0 & 0 & 0 & 0 & 0 \\
\hline Benzene & 0 & 0 & 0 & 0 & 0 & 0 & 0 & 0 & 0 & 0 & 0 & 0 & 0 & 0 \\
\hline Naphthalene & 0 & 0 & 0 & 0 & 0 & 0 & 0 & 0 & 0 & 0 & 0 & 0 & 0 & 0 \\
\hline Hybrid Poplar Ch & 0 & 0 & 0 & 0 & 0 & 0 & 0 & 0 & 0 & 0 & 0 & 0 & 0 & 0 \\
\hline Sulfur Dioxide & 0 & 0 & 0 & 0 & 0 & 0 & 0 & 0 & 0 & 0 & 0 & 0 & 0 & 0 \\
\hline Hydrogen Cyanide & 0 & 0 & 0.3855 & 0.3855 & 0.6524 & 0 & 0 & 0.2227 & 0 & 0 & 0 & 0 & 0 & 0 \\
\hline Nitric Oxide & 0 & 0 & 0 & 0 & 0 & 0 & 0 & 0 & 0 & 0 & 0 & 0 & 0 & 0 \\
\hline Methanol & 0 & 0 & 2631.6499 & 2631.6511 & 2631.7458 & 12238.166 & 12238.166 & 722.9219 & 13735.4697 & 13735.4697 & 13597.9639 & 1359.7964 & 12238.1699 & 137.5055 \\
\hline Ethanol & 0 & 0 & \begin{tabular}{|l|}
5707.208 \\
\end{tabular} & 5707.208 & 5707.2822 & 34.2131 & 34.2131 & 27.4586 & 38090.9297 & 38090.9297 & 38.0146 & 3.8015 & 34.2131 & 38052.8984 \\
\hline Isopropanol & 0 & 0 & 0 & 0 & 0 & 0 & 0 & 0 & 0 & 0 & 0 & 0 & 0 & 0 \\
\hline \begin{tabular}{|l|} 
N-Propanol \\
\end{tabular} & 0 & 0 & 668.3553 & 668.3557 & 668.366 & 0.2587 & 0.2587 & 0.0005 & 7903.7593 & 7903.7593 & 0.2874 & 0.0287 & 0.2587 & 7903.4678 \\
\hline Isobutanol & 0 & 0 & 0 & 0 & 0 & 0 & 0 & 0 & 0 & 0 & 0 & 0 & 0 & 0 \\
\hline N-Butanol & 0 & 0 & 160.3767 & 160.3768 & 160.3787 & 0 & 0 & 0 & 3388.8984 & 3388.8984 & 0 & 0 & 0 & 3388.897 \\
\hline 1-Pentanol & 0 & 0 & (79.7514 & 79.7514 & 79.7522 & 0 & 0 & 0 & 1694.1589 & 1694.1589 & 0 & 0 & 0 & 1694.1578 \\
\hline
\end{tabular}


Table B.2. ( contd)

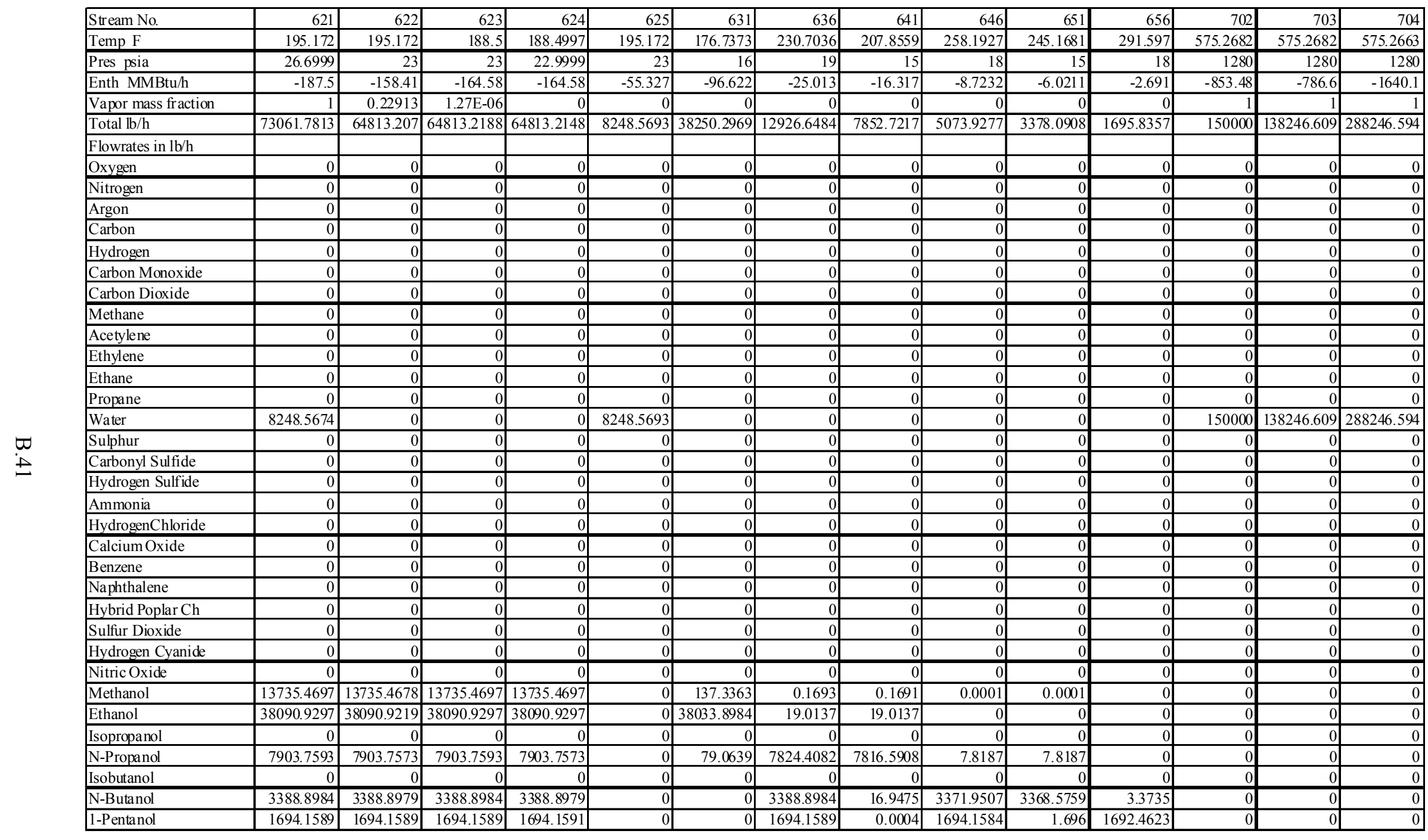


Table B.2. (contd)

\begin{tabular}{|c|c|c|c|c|c|c|c|c|c|c|c|c|c|c|}
\hline Stream No. & 706 & 707 & 708 & 710 & 712 & 715 & 718 & 719 & 720 & 721 & 725 & 731 & 732 & 733 \\
\hline Temp F & 575 & 575 & 575 & 575 & 574.9981 & 222.1747 & 574.9981 & 200 & 1000 & 1000 & 1000 & 715.252 & 715.252 & 715.252 \\
\hline Pres psia & 1277.3452 & 1277.3452 & 1277.3452 & 1277.3452 & 1277.3452 & 35 & 1277.345 & 1277.345 & 1265 & 1265 & 1265 & 450 & 450 & 450 \\
\hline Enth MMBtu/h & -1623.7 & -827.09 & $\begin{array}{r}-796.57 \\
\end{array}$ & -18.117 & 0 & 0 & \begin{tabular}{|l|}
-18.117 \\
\end{tabular} & -19.32 & $\mid-781.17$ & -752.34 & -1533.5 & -1570.3 & -330.17 & -229.77 \\
\hline Vapor mass fraction & 1 & 1 & 1 & 0 & 1 & 1 & 0 & 0 & 1 & 1 & 1 & 1 & 1 & 1 \\
\hline Total lb/h & 285364.125 & 145364.141 & 140000 & 2882.4702 & 0 & 0 & 2882.47 & 2882.4702 & 145364 & 140000 & 285364 & 285364 & 60000 & 41754 \\
\hline Flowrates in $\mathrm{lb} / \mathrm{h}$ & & & & & & 1 & & & & & & & & \\
\hline Oxygen & 0 & 0 & 0 & 0 & 0 & 0 & 0 & 0 & 0 & 0 & 0 & 0 & 0 & 0 \\
\hline Nitrogen & 0 & 0 & 0 & 0 & 0 & 0 & 0 & 0 & 0 & 0 & 0 & 0 & 0 & $\overline{0}$ \\
\hline Argon & 0 & 0 & 0 & 0 & 0 & 0 & 0 & 0 & 0 & 0 & 0 & 0 & 0 & 0 \\
\hline Carbon & 0 & 0 & 0 & 0 & 0 & 0 & 0 & 0 & 0 & 0 & 0 & 0 & 0 & 0 \\
\hline Hydrogen & 0 & 0 & 0 & 0 & 0 & 0 & 0 & 0 & 0 & 0 & 0 & 0 & 0 & 0 \\
\hline Carbon Monoxide & 0 & 0 & 0 & 0 & 0 & 0 & 0 & 0 & 0 & 0 & 0 & 0 & 0 & 0 \\
\hline \begin{tabular}{|l|} 
Carbon Dioxide \\
\end{tabular} & 0 & 0 & 0 & 0 & 0 & 0 & 0 & 0 & 0 & 0 & 0 & 0 & 0 & 0 \\
\hline Methane & 0 & 0 & 0 & 0 & 0 & 0 & 0 & 0 & 0 & 0 & 0 & 0 & 0 & $\overline{0}$ \\
\hline \begin{tabular}{|l|} 
Acetylene \\
\end{tabular} & 0 & 0 & 0 & 0 & 0 & 0 & 0 & 0 & 0 & 0 & 0 & 0 & 0 & 0 \\
\hline \begin{tabular}{|l|} 
Ethylene \\
\end{tabular} & 0 & 0 & 0 & 0 & 0 & 0 & 0 & 0 & 0 & 0 & 0 & 0 & 0 & 0 \\
\hline Ethane & 0 & 0 & 0 & 0 & 0 & 0 & 0 & 0 & 0 & 0 & 0 & 0 & 0 & 0 \\
\hline Propane & 0 & 0 & 0 & 0 & 0 & 0 & 0 & 0 & 0 & 0 & 0 & 0 & 0 & 0 \\
\hline Water & 285364.125 & 145364.141 & 140000 & 2882.4702 & 0 & 0 & 2882.47 & 2882.4702 & 145364 & 140000 & 285364 & 285364 & 60000 & 41754 \\
\hline Sulphur & 0 & $\begin{array}{r}0 \\
\end{array}$ & 0 & 0 & 0 & 0 & $\begin{array}{r}0 \\
\end{array}$ & 0 & 0 & 0 & 0 & 0 & 0 & 0 \\
\hline Carbonyl Sulfide & 0 & 0 & 0 & 0 & 0 & 0 & 0 & 0 & 0 & 0 & 0 & 0 & 0 & 0 \\
\hline Hydrogen Sulfide & 0 & 0 & 0 & 0 & 0 & 0 & 0 & 0 & 0 & 0 & 0 & 0 & 0 & 0 \\
\hline Ammonia & 0 & 0 & 0 & 0 & 0 & 0 & 0 & 0 & 0 & 0 & 0 & 0 & 0 & 0 \\
\hline HydrogenChloride & 0 & 0 & 0 & 0 & 0 & 0 & 0 & 0 & 0 & 0 & 0 & 0 & 0 & 0 \\
\hline Calcium Oxide & 0 & 0 & 0 & 0 & 0 & 0 & 0 & 0 & 0 & 0 & 0 & 0 & 0 & 0 \\
\hline Benzene & 0 & 0 & 0 & 0 & 0 & 0 & 0 & 0 & 0 & 0 & 0 & 0 & 0 & 0 \\
\hline Naphthalene & 0 & 0 & 0 & 0 & 0 & 0 & 0 & 0 & 0 & 0 & 0 & 0 & 0 & 0 \\
\hline Hybrid Poplar Ch & 0 & 0 & 0 & 0 & 0 & 0 & 0 & 0 & 0 & 0 & 0 & 0 & 0 & 0 \\
\hline \begin{tabular}{|l} 
Sulfur Dioxide \\
\end{tabular} & 0 & 0 & 0 & 0 & 0 & 0 & 0 & 0 & 0 & 0 & 0 & 0 & 0 & 0 \\
\hline Hydrogen Cyanide & 0 & 0 & 0 & 0 & 0 & 0 & 0 & 0 & 0 & 0 & 0 & 0 & 0 & 0 \\
\hline Nitric Oxide & 0 & 0 & 0 & 0 & 0 & 0 & 0 & 0 & 0 & 0 & 0 & 0 & 0 & 0 \\
\hline \begin{tabular}{|l|} 
Methanol \\
\end{tabular} & 0 & 0 & 0 & 0 & 0 & 0 & 0 & 0 & 0 & 0 & 0 & 0 & 0 & 0 \\
\hline Ethanol & 0 & 0 & 0 & 0 & 0 & 0 & 0 & 0 & 0 & 0 & 0 & 0 & 0 & 0 \\
\hline Isopropanol & 0 & 0 & 0 & 0 & 0 & 0 & 0 & 0 & 0 & 0 & 0 & 0 & 0 & 0 \\
\hline N-Propanol & 0 & 0 & 0 & 0 & 0 & 0 & 0 & 0 & 0 & 0 & 0 & 0 & 0 & 0 \\
\hline Isobutanol & 0 & 0 & 0 & 0 & 0 & 0 & 0 & 0 & 0 & 0 & 0 & 0 & 0 & 0 \\
\hline N-Butanol & 0 & 0 & 0 & 0 & 0 & 0 & 0 & 0 & 0 & 0 & 0 & 0 & 0 & 0 \\
\hline 1-Pentanol & 0 & 0 & 0 & 0 & 0 & 0 & 0 & 0 & 0 & 0 & 0 & 0 & 0 & 0 \\
\hline
\end{tabular}


Table B.2. (contd)

\begin{tabular}{|c|c|c|c|c|c|c|c|c|c|c|c|c|c|c|}
\hline Stream No. & 734 & 736 & 737 & 738 & 739 & 741 & 743 & 744 & 745 & 746 & 751 & 761 & 762 & 770 \\
\hline Temp F & 715.252 & 715.252 & 456.3709 & 720 & 717.3339 & 277.5191 & 277.5191 & 277.5191 & 277.5191 & 277.5191 & 115.5419 & 115.5419 & 115.6689 & 60 \\
\hline Pres psia & 450 & 450 & 450 & 450 & 450 & 35 & 35 & 35 & 35 & 35 & 1.5 & 1.5 & 35 & 60 \\
\hline Enth MMBtu/h & -43.99 & -966.39 & -778.18 & $\mid-754.41$ & -1720.8 & $\mid-1781.1$ & \begin{tabular}{|l|}
-194.53 \\
\end{tabular} & -1152.4 & -365.85 & $\begin{array}{l}-68.334 \\
\end{array}$ & -376.13 & -436.06 & -436.05 & -716.01 \\
\hline Vapor mass fraction & 1 & 1 & 0.99074 & 1 & 1 & 1 & 1 & 1 & 1 & 1 & 0.90745 & 0 & 0 & 0 \\
\hline Total lb/h & 7994 & 175616 & 137159.141 & 137159.141 & 312775.156 & 312775.156 & 34160 & 202369 & \begin{tabular}{|l|}
64246.1602 \\
\end{tabular} & 12000 & 64246.1602 & 64246.1602 & 64246.1602 & 104637 \\
\hline Flowrates in $\mathrm{lb} / \mathrm{h}$ & & & & & & & & & & & & & & \\
\hline Oxygen & 0 & 0 & 0 & 0 & 0 & 0 & 0 & 0 & 0 & 0 & 0 & 0 & 0 & 0 \\
\hline Nitrogen & 0 & 0 & 0 & 0 & 0 & 0 & 0 & 0 & 0 & 0 & 0 & 0 & 0 & 0 \\
\hline Argon & 0 & 0 & 0 & 0 & 0 & 0 & 0 & 0 & 0 & 0 & 0 & 0 & 0 & 0 \\
\hline Carbon & 0 & 0 & 0 & 0 & 0 & 0 & 0 & 0 & 0 & 0 & 0 & 0 & 0 & 0 \\
\hline Hydrogen & 0 & 0 & 0 & 0 & 0 & 0 & 0 & 0 & 0 & 0 & 0 & 0 & 0 & 0 \\
\hline Carbon Monoxide & 0 & 0 & 0 & 0 & 0 & 0 & 0 & 0 & 0 & 0 & 0 & 0 & 0 & 0 \\
\hline Carbon Dioxide & 0 & 0 & 0 & 0 & 0 & 0 & 0 & 0 & 0 & 0 & 0 & 0 & 0 & 0 \\
\hline Methane & 0 & 0 & 0 & 0 & 0 & 0 & 0 & 0 & 0 & 0 & 0 & 0 & 0 & 0 \\
\hline Acetylene & 0 & 0 & 0 & 0 & 0 & 0 & 0 & 0 & 0 & 0 & 0 & 0 & 0 & 0 \\
\hline Ethylene & 0 & 0 & 0 & 0 & 0 & 0 & 0 & 0 & 0 & 0 & 0 & 0 & 0 & 0 \\
\hline Ethane & 0 & 0 & 0 & 0 & 0 & 0 & 0 & 0 & 0 & 0 & 0 & 0 & 0 & 0 \\
\hline Propane & 0 & 0 & 0 & 0 & 0 & 0 & 0 & 0 & 0 & 0 & 0 & 0 & \begin{tabular}{r|}
0 \\
\end{tabular} & 0 \\
\hline Water & 7994 & 175616 & 137159.141 & 137159.141 & 312775.156 & 312775.156 & 34160 & 202369 & 64246.1602 & 12000 & 64246.1602 & 64246.1602 & 64246.1602 & 104637 \\
\hline Sulphur & 0 & 0 & 0 & 0 & \begin{tabular}{r|}
0 \\
0
\end{tabular} & \begin{tabular}{r|}
0 \\
\end{tabular} & 0 & 0 & \begin{tabular}{r|}
0 \\
\end{tabular} & 0 & \begin{tabular}{r|}
0 \\
\end{tabular} & 0 & \begin{tabular}{r|}
0 \\
\end{tabular} & 0 \\
\hline Carbonyl Sulfide & 0 & 0 & 0 & 0 & 0 & 0 & 0 & 0 & 0 & 0 & 0 & 0 & 0 & 0 \\
\hline Hydrogen Sulfide & 0 & 0 & 0 & 0 & 0 & 0 & 0 & 0 & 0 & 0 & 0 & 0 & 0 & 0 \\
\hline Ammonia & 0 & 0 & 0 & 0 & 0 & 0 & 0 & 0 & 0 & 0 & 0 & 0 & 0 & 0 \\
\hline HydrogenChloride & 0 & 0 & 0 & 0 & 0 & 0 & 0 & 0 & 0 & 0 & 0 & 0 & 0 & 0 \\
\hline Calcium Oxide & 0 & 0 & 0 & 0 & 0 & 0 & 0 & 0 & 0 & 0 & 0 & 0 & 0 & 0 \\
\hline Benzene & 0 & 0 & 0 & 0 & 0 & 0 & 0 & 0 & 0 & 0 & 0 & 0 & 0 & 0 \\
\hline Naphthalene & 0 & 0 & 0 & 0 & 0 & 0 & 0 & 0 & 0 & 0 & 0 & 0 & 0 & 0 \\
\hline Hybrid Poplar Ch & 0 & 0 & 0 & 0 & 0 & 0 & 0 & 0 & 0 & 0 & 0 & 0 & 0 & 0 \\
\hline Sulfur Dioxide & 0 & 0 & 0 & 0 & 0 & 0 & 0 & 0 & 0 & 0 & 0 & 0 & 0 & 0 \\
\hline Hydrogen Cyanide & 0 & 0 & 0 & 0 & 0 & 0 & 0 & 0 & 0 & 0 & 0 & 0 & 0 & 0 \\
\hline Nitric Oxide & 0 & 0 & 0 & 0 & 0 & 0 & 0 & 0 & 0 & 0 & 0 & 0 & 0 & 0 \\
\hline Methanol & 0 & 0 & 0 & 0 & 0 & 0 & 0 & 0 & 0 & 0 & 0 & 0 & 0 & 0 \\
\hline Ethanol & 0 & 0 & 0 & 0 & 0 & 0 & 0 & 0 & 0 & 0 & 0 & 0 & 0 & 0 \\
\hline Isopropanol & 0 & 0 & 0 & 0 & 0 & 0 & 0 & 0 & 0 & 0 & 0 & 0 & 0 & 0 \\
\hline N-Propanol & 0 & 0 & 0 & 0 & 0 & 0 & 0 & 0 & 0 & 0 & 0 & 0 & 0 & 0 \\
\hline Isobutanol & 0 & 0 & 0 & 0 & 0 & 0 & 0 & 0 & 0 & 0 & 0 & 0 & 0 & 0 \\
\hline N-Butanol & 0 & 0 & 0 & 0 & 0 & 0 & 0 & 0 & 0 & 0 & 0 & 0 & 0 & 0 \\
\hline 1-Pentanol & 0 & 0 & 0 & 0 & 0 & 0 & 0 & 0 & 0 & 0 & 0 & 0 & 0 & 0 \\
\hline
\end{tabular}


Table B.2. (contd)

\begin{tabular}{|c|c|c|c|c|c|c|c|c|c|c|c|c|c|c|}
\hline \begin{tabular}{|l} 
Stream No. \\
\end{tabular} & 771 & 772 & 773 & 775 & 776 & 778 & 781 & 782 & 783 & 784 & 792 & 793 & 794 & 795 \\
\hline Temp F & 71.5014 & 259.3462 & 456 & 259 & 259.3462 & 222.1747 & 223.7356 & 223.7356 & 226.2917 & 223.7356 & 575.2682 & 575.2682 & 1000 & 720 \\
\hline Pres psia & 60 & 35 & 450 & 35 & 35 & 35 & 450 & 450 & 1280.8 & 450 & 1280 & 1280 & 1265 & 450 \\
\hline Enth MMBtu/h & -714.81 & -226.91 & -51.414 & -1344.3 & -1624.2 & -2841.8 & $\mid-2841.1$ & -1925.1 & $\mid-1924.3$ & -916.03 & -853.48 & -786.6 & $\mid-781.17$ & -754.41 \\
\hline Vapor mass fraction & 0 & 0 & 0 & 0 & 0 & 0 & 0 & 0 & 0 & 0 & 1 & 1 & 1 & 1 \\
\hline Total lb/h & 104637 & 34160 & 7994 & 202369 & 244523 & 425406.156 & 425406.156 & 288247.156 & 288247.156 & 137159 & 150000 & 138246.609 & 145364 & 137159.141 \\
\hline Flowrates in $\mathrm{lb} / \mathrm{h}$ & & & & & & & 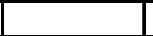 & 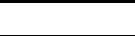 & 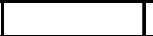 & & 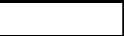 & & 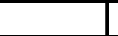 & \\
\hline Oxygen & 0 & 0 & 0 & 0 & 0 & 0 & 0 & 0 & 0 & 0 & 0 & 0 & 0 & 0 \\
\hline Nitrogen & 0 & 0 & 0 & 0 & 0 & 0 & 0 & $\overline{0}$ & 0 & $\overline{0}$ & 0 & 0 & 0 & $\overline{0}$ \\
\hline \begin{tabular}{|l|} 
Argon \\
\end{tabular} & 0 & 0 & 0 & 0 & 0 & 0 & 0 & 0 & 0 & 0 & 0 & 0 & 0 & $\overline{0}$ \\
\hline Carbon & 0 & 0 & 0 & 0 & 0 & 0 & 0 & 0 & 0 & 0 & 0 & 0 & 0 & 0 \\
\hline Hydrogen & 0 & 0 & 0 & 0 & 0 & 0 & 0 & 0 & 0 & 0 & 0 & 0 & 0 & 0 \\
\hline Carbon Monoxide & 0 & 0 & 0 & 0 & 0 & 0 & 0 & 0 & 0 & 0 & 0 & 0 & 0 & 0 \\
\hline Carbon Dioxide & 0 & 0 & 0 & 0 & 0 & 0 & 0 & 0 & 0 & 0 & 0 & 0 & 0 & 0 \\
\hline Methane & 0 & 0 & 0 & 0 & 0 & 0 & 0 & 0 & 0 & 0 & 0 & 0 & 0 & 0 \\
\hline Acetylene & 0 & 0 & 0 & 0 & 0 & 0 & 0 & 0 & 0 & 0 & 0 & 0 & 0 & 0 \\
\hline Ethylene & 0 & 0 & 0 & 0 & 0 & 0 & 0 & 0 & 0 & 0 & 0 & 0 & 0 & 0 \\
\hline Ethane & 0 & 0 & 0 & 0 & 0 & 0 & 0 & 0 & 0 & 0 & 0 & 0 & 0 & 0 \\
\hline Propane & 0 & 0 & 0 & 0 & 0 & 0 & 0 & 0 & 0 & 0 & 0 & 0 & 0 & 0 \\
\hline Water & 104637 & 34160 & 7994 & 202369 & 244523 & 425406.156 & 425406.156 & 288247.156 & 288247.156 & 137159 & 150000 & 138246.609 & 145364 & 137159.141 \\
\hline Sulphur & 0 & 0 & 0 & 0 & 0 & 0 & \begin{tabular}{|l|}
0 \\
\end{tabular} & 0 & 0 & 0 & 0 & 0 & 0 & 0 \\
\hline Carbonyl Sulfide & 0 & 0 & 0 & 0 & 0 & 0 & 0 & 0 & 0 & 0 & 0 & 0 & 0 & $\overline{0}$ \\
\hline Hydrogen Sulfide & 0 & 0 & 0 & 0 & 0 & 0 & 0 & 0 & 0 & 0 & 0 & 0 & 0 & 0 \\
\hline \begin{tabular}{|l|} 
Ammonia \\
\end{tabular} & 0 & 0 & 0 & 0 & 0 & 0 & 0 & 0 & 0 & 0 & 0 & 0 & 0 & 0 \\
\hline HydrogenChloride & 0 & 0 & 0 & 0 & 0 & 0 & 0 & 0 & 0 & 0 & 0 & 0 & 0 & 0 \\
\hline Calcium Oxide & 0 & 0 & 0 & 0 & 0 & 0 & 0 & 0 & 0 & 0 & 0 & $\overline{0}$ & 0 & $\overline{0}$ \\
\hline Benzene & 0 & 0 & 0 & 0 & 0 & 0 & 0 & 0 & 0 & 0 & 0 & 0 & 0 & 0 \\
\hline Naphthalene & 0 & 0 & 0 & 0 & 0 & 0 & 0 & 0 & 0 & 0 & 0 & 0 & 0 & 0 \\
\hline Hybrid Poplar Ch & 0 & 0 & 0 & 0 & 0 & 0 & 0 & 0 & 0 & 0 & 0 & 0 & 0 & 0 \\
\hline \begin{tabular}{|l|} 
Sulfur Dioxide \\
\end{tabular} & 0 & 0 & 0 & 0 & 0 & 0 & 0 & 0 & 0 & 0 & 0 & 0 & 0 & 0 \\
\hline Hydrogen Cyanide & 0 & 0 & 0 & 0 & 0 & 0 & 0 & 0 & 0 & 0 & 0 & 0 & 0 & 0 \\
\hline Nitric Oxide & 0 & 0 & 0 & 0 & 0 & 0 & 0 & 0 & 0 & 0 & 0 & 0 & 0 & 0 \\
\hline Methanol & 0 & 0 & 0 & 0 & 0 & 0 & 0 & 0 & 0 & 0 & 0 & 0 & 0 & 0 \\
\hline Ethanol & 0 & 0 & 0 & 0 & 0 & 0 & 0 & 0 & 0 & 0 & 0 & 0 & 0 & 0 \\
\hline Isopropanol & 0 & 0 & 0 & 0 & 0 & 0 & 0 & 0 & 0 & 0 & 0 & 0 & 0 & 0 \\
\hline N-Propanol & 0 & 0 & 0 & 0 & 0 & 0 & 0 & 0 & 0 & 0 & 0 & 0 & 0 & 0 \\
\hline Isobutanol & 0 & 0 & 0 & 0 & 0 & 0 & 0 & 0 & 0 & 0 & 0 & 0 & 0 & 0 \\
\hline N-Butanol & 0 & 0 & 0 & 0 & 0 & 0 & 0 & 0 & 0 & 0 & 0 & 0 & 0 & 0 \\
\hline 1-Pentanol & 0 & 0 & 0 & 0 & 0 & 0 & 0 & 0 & 0 & 0 & 0 & 0 & 0 & 0 \\
\hline
\end{tabular}


Table B.2. (contd)

\begin{tabular}{|c|c|c|c|c|c|c|c|c|c|c|c|c|c|c|}
\hline Stream No. & 796 & 1602 & 1605 & 1607 & 1608 & 1702 & 1748 & 1830 & 1831 & 1835 & 1836 & 1841 & 1842 & 1844 \\
\hline Temp F & 1000 & 44.7393 & 44.7393 & 44.7393 & 44.7393 & 116.4856 & 110 & 90 & 110 & 90 & 110 & 90 & 110 & 90 \\
\hline Pres psia & 1265 & 16 & 16 & 16 & 16 & 324 & 416.5 & 60 & 60 & 60 & 60 & 65 & 65 & 65 \\
\hline Enth MMBtu/h & -752.34 & \begin{tabular}{|l|}
-71.632 \\
\end{tabular} & -52.188 & \begin{tabular}{|c|}
-17 \\
\end{tabular} & -2.4441 & -582.96 & $\mid-412.12$ & -17690 & -17638 & -2602.7 & -2595 & -2634.2 & -2626.4 & -1810.3 \\
\hline Vapor mass fraction & 1 & 0.97452 & 0.97452 & 0.97452 & 0.97452 & 0 & 0 & 0 & 0 & 0 & 0 & 0 & 0 & 0 \\
\hline Total lb/h & 140000 & 32866.4063 & 23945 & 7800 & 1121.4208 & 86395 & 60670 & 2596518.75 & 2596518.5 & 382027 & 382027 & 386649.563 & 386649.531 & 265720.313 \\
\hline Flowrates in $\mathrm{lb} / \mathrm{h}$ & & & & & & & & & & & & & & \\
\hline Oxygen & 0 & 0 & 0 & 0 & 0 & 0 & 0 & 0 & 0 & 0 & 0 & 0 & 0 & 0 \\
\hline Nitrogen & 0 & 887.3789 & 646.5046 & 210.5966 & 30.2779 & 0.0542 & 0 & 0 & 0 & 0 & 0 & 0 & 0 & 0 \\
\hline Argon & 0 & 154.2041 & 112.3462 & 36.5964 & 5.2615 & 0.0285 & 0 & 0 & 0 & 0 & 0 & 0 & 0 & 0 \\
\hline Carbon & 0 & 0 & 0 & 0 & 0 & 0 & 0 & 0 & 0 & 0 & 0 & 0 & 0 & 0 \\
\hline Hydrogen & 0 & 416.742 & 303.6196 & 98.903 & 14.2195 & 1.048 & 0 & 0 & 0 & 0 & 0 & 0 & 0 & 0 \\
\hline Carbon Monoxide & 0 & 6626.3604 & 4827.6704 & 1572.5968 & 226.0952 & 11.2948 & 0 & 0 & 0 & 0 & 0 & 0 & 0 & 0 \\
\hline Carbon Dioxide & 0 & 4446.584 & 3239.5835 & 1055.283 & $\begin{array}{l}151.72 \\
\end{array}$ & 396.8466 & 0 & 0 & 0 & 0 & 0 & 0 & 0 & 0 \\
\hline Methane & 0 & 16375.1113 & 11930.1758 & 3886.2134 & 558.7283 & 2.8089 & 0 & 0 & 0 & 0 & 0 & 0 & 0 & 0 \\
\hline Acetylene & 0 & 0 & 0 & 0 & 0 & 0 & 0 & 0 & 0 & 0 & 0 & 0 & 0 & 0 \\
\hline Ethylene & 0 & 0.4543 & 0.331 & 0.1078 & 0.0155 & 1.172 & 0 & 0 & 0 & 0 & 0 & 0 & 0 & 0 \\
\hline Ethane & 0 & 753.1939 & 548.7436 & 178.7513 & 25.6994 & 0.3724 & 0 & 0 & 0 & 0 & 0 & 0 & 0 & 0 \\
\hline Propane & 0 & 0 & $\begin{array}{r}0 \\
\end{array}$ & $\begin{array}{r}0 \\
\end{array}$ & 0 & 0 & 0 & 0 & 0 & 0 & 0 & 0 & $\begin{array}{r}0 \\
\end{array}$ & 0 \\
\hline Water & 140000 & 130.7155 & 95.2335 & 31.022 & 4.4601 & 85592.1797 & 60670 & 2596518.75 & 2596518.5 & 382027 & 382027 & 386649.563 & 386649.531 & 265720.313 \\
\hline Sulphur & 0 & 0 & 0 & 0 & 0 & 0 & 0 & 0 & 0 & 0 & 0 & 0 & $\begin{array}{r}0 \\
\end{array}$ & 0 \\
\hline Carbonyl Sulfide & 0 & 0 & 0 & 0 & 0 & 0 & 0 & 0 & 0 & 0 & 0 & 0 & 0 & 0 \\
\hline Hydrogen Sulfide & 0 & 0 & 0 & 0 & 0 & 0.2454 & 0 & 0 & 0 & 0 & 0 & 0 & 0 & 0 \\
\hline Ammonia & 0 & 15.3492 & 11.1828 & 3.6428 & 0.5237 & 319.5696 & 0 & 0 & 0 & 0 & 0 & 0 & 0 & 0 \\
\hline HydrogenChloride & 0 & 0 & 0 & 0 & 0 & 18.5294 & 0 & 0 & 0 & 0 & 0 & 0 & 0 & 0 \\
\hline Calcium Oxide & 0 & 0 & 0 & 0 & 0 & 0 & 0 & 0 & 0 & 0 & 0 & 0 & 0 & 0 \\
\hline Benzene & 0 & 0 & 0 & 0 & 0 & 38.3926 & 0 & 0 & 0 & 0 & 0 & 0 & 0 & 0 \\
\hline Naphthalene & 0 & 0 & 0 & 0 & 0 & 12.3952 & 0 & 0 & 0 & 0 & 0 & 0 & 0 & 0 \\
\hline Hybrid Poplar Ch & 0 & 0 & 0 & 0 & 0 & 0 & 0 & 0 & 0 & 0 & 0 & 0 & 0 & 0 \\
\hline Sulfur Dioxide & 0 & 0 & 0 & 0 & 0 & 0 & 0 & 0 & 0 & 0 & 0 & 0 & 0 & 0 \\
\hline Hydrogen Cyanide & 0 & 0.2669 & 0.1945 & 0.0634 & 0.0091 & 0 & 0 & 0 & 0 & 0 & 0 & 0 & 0 & 0 \\
\hline Nitric Oxide & 0 & 0 & 0 & \begin{tabular}{r|}
0 \\
\end{tabular} & 0 & 0 & 0 & 0 & 0 & 0 & 0 & 0 & 0 & 0 \\
\hline Methanol & 0 & 2370.4077 & 1726.9731 & 562.5555 & 80.8797 & 0 & 0 & 0 & 0 & 0 & 0 & 0 & 0 & 0 \\
\hline Ethanol & 0 & 611.8943 & 4445.799 & 145.2175 & 20.8782 & 0 & 0 & 0 & 0 & 0 & 0 & 0 & 0 & 0 \\
\hline Isopropanol & 0 & 0 & 0 & 0 & 0 & 0 & 0 & 0 & 0 & 0 & 0 & 0 & 0 & 0 \\
\hline N-Propanol & 0 & 59.5707 & 43.4006 & 14.1376 & 2.0326 & 0 & 0 & 0 & 0 & 0 & 0 & 0 & 0 & 0 \\
\hline Isobutanol & 0 & 0 & 0 & 0 & 0 & 0 & 0 & 0 & 0 & 0 & 0 & 0 & 0 & 0 \\
\hline N-Butanol & 0 & 12.4893 & 9.0992 & 2.964 & 0.4261 & 0 & 0 & 0 & 0 & 0 & 0 & 0 & 0 & 0 \\
\hline 1-Pentanol & 0 & 5.6836 & 4.1408 & \begin{tabular}{l|}
1.3488 \\
\end{tabular} & 0.1939 & 0 & 0 & 0 & 0 & 0 & 0 & 0 & 0 & 0 \\
\hline
\end{tabular}


Table B.2. (contd)

\begin{tabular}{|c|c|c|c|c|c|c|c|c|c|c|c|c|c|c|}
\hline Stream No. & 1845 & 1850 & 1851 & 1861 & 1862 & 1930 & 1931 & 1935 & 1936 & 1938 & 1940 & 1943 & 1944 & 1945 \\
\hline Temp F & 105 & 90 & 110 & 90 & 110 & 715.0002 & 715.0002 & 230 & 400 & 575.2682 & 715.0002 & 573.7587 & 1000 & 456.3709 \\
\hline Pres psia & 65 & 65 & 60 & 60 & 60 & 450 & 450 & 1280 & 1280 & 1280 & 450 & 1265 & 1265 & 450 \\
\hline Enth MMBtu/h & -1806.3 & -2843.1 & -2834.7 & -2099.4 & -2093.2 & -229.77 & -229.77 & -1000.8 & -974.17 & -853.48 & -330.18 & -827.01 & -781.17 & -778.18 \\
\hline Vapor mass fraction & 0 & 0 & 0 & 0 & 0 & 1 & 1 & 0 & 0 & 1 & 1 & 1 & 1 & 0.99074 \\
\hline Total lb/h & 265720.313 & 417314 & 417314 & 308154.563 & 308154.563 & 41753.7578 & 41753.7578 & 150000 & 150000 & 150000 & 60000 & 145364 & 145364 & 137159.141 \\
\hline Flowrates in $\mathrm{lb} / \mathrm{h}$ & & & & & & & & & & & & & & \\
\hline Oxygen & 0 & 0 & 0 & 0 & 0 & 0 & 0 & 0 & 0 & 0 & 0 & 0 & 0 & 0 \\
\hline Nitrogen & 0 & 0 & 0 & 0 & 0 & 0 & 0 & 0 & 0 & 0 & 0 & 0 & 0 & 0 \\
\hline Argon & 0 & 0 & 0 & 0 & 0 & 0 & 0 & 0 & 0 & 0 & 0 & 0 & 0 & 0 \\
\hline Carbon & 0 & 0 & 0 & 0 & 0 & 0 & 0 & 0 & 0 & 0 & 0 & 0 & 0 & 0 \\
\hline Hydrogen & 0 & 0 & 0 & 0 & 0 & 0 & 0 & 0 & 0 & 0 & 0 & 0 & 0 & 0 \\
\hline Carbon Monoxide & 0 & 0 & 0 & 0 & 0 & 0 & 0 & 0 & 0 & 0 & 0 & 0 & 0 & 0 \\
\hline Carbon Dioxide & 0 & 0 & 0 & 0 & 0 & 0 & 0 & 0 & 0 & 0 & 0 & 0 & 0 & 0 \\
\hline Methane & 0 & 0 & 0 & 0 & 0 & 0 & 0 & 0 & 0 & $\overline{0}$ & 0 & 0 & 0 & 0 \\
\hline Acetylene & 0 & 0 & 0 & 0 & 0 & 0 & 0 & 0 & 0 & $\overline{0}$ & 0 & 0 & 0 & 0 \\
\hline \begin{tabular}{|l|} 
Ethylene \\
\end{tabular} & 0 & 0 & 0 & 0 & 0 & 0 & 0 & 0 & 0 & 0 & 0 & 0 & 0 & 0 \\
\hline Ethane & 0 & 0 & 0 & 0 & 0 & 0 & 0 & 0 & 0 & 0 & 0 & 0 & 0 & 0 \\
\hline Propane & 0 & 0 & 0 & 0 & $\overline{0}$ & 0 & 0 & 0 & 0 & 0 & 0 & 0 & 0 & 0 \\
\hline Water & 265720.313 & 417314 & 417314 & 308154.563 & 308154.563 & 41753.7578 & 41753.7578 & 150000 & 150000 & 150000 & 60000 & 145364 & 145364 & 137159.141 \\
\hline \begin{tabular}{|l} 
Sulphur \\
\end{tabular} & $\begin{array}{r}0 \\
\end{array}$ & 0 & 0 & 0 & 0 & 0 & 0 & 0 & 0 & 0 & 0 & 0 & 0 & 0 \\
\hline Carbonyl Sulfide & 0 & 0 & 0 & 0 & 0 & 0 & 0 & 0 & 0 & 0 & 0 & 0 & 0 & 0 \\
\hline Hydrogen Sulfide & 0 & 0 & 0 & 0 & 0 & 0 & 0 & 0 & 0 & 0 & 0 & 0 & 0 & 0 \\
\hline Ammonia & 0 & 0 & 0 & 0 & 0 & 0 & 0 & 0 & 0 & 0 & 0 & 0 & 0 & 0 \\
\hline HydrogenChloride & 0 & 0 & 0 & 0 & 0 & 0 & 0 & 0 & 0 & 0 & 0 & 0 & 0 & 0 \\
\hline Calcium Oxide & 0 & 0 & 0 & 0 & 0 & 0 & 0 & 0 & 0 & 0 & 0 & 0 & 0 & 0 \\
\hline Benzene & 0 & 0 & 0 & 0 & 0 & 0 & 0 & 0 & 0 & 0 & 0 & 0 & 0 & 0 \\
\hline Naphthalene & 0 & 0 & 0 & 0 & 0 & 0 & 0 & 0 & 0 & 0 & 0 & 0 & 0 & 0 \\
\hline Hybrid Poplar Ch & 0 & 0 & 0 & 0 & 0 & 0 & 0 & 0 & 0 & 0 & 0 & 0 & 0 & 0 \\
\hline Sulfur Dioxide & 0 & 0 & 0 & 0 & 0 & 0 & 0 & 0 & 0 & 0 & 0 & 0 & 0 & 0 \\
\hline Hydrogen Cyanide & 0 & 0 & 0 & 0 & 0 & 0 & 0 & 0 & 0 & 0 & 0 & 0 & 0 & 0 \\
\hline Nitric Oxide & 0 & 0 & 0 & 0 & 0 & 0 & 0 & 0 & 0 & 0 & 0 & 0 & 0 & 0 \\
\hline Methanol & 0 & 0 & 0 & 0 & 0 & 0 & 0 & 0 & 0 & 0 & 0 & 0 & 0 & 0 \\
\hline Ethanol & 0 & 0 & 0 & 0 & 0 & 0 & 0 & 0 & 0 & 0 & 0 & 0 & 0 & 0 \\
\hline \begin{tabular}{|l|} 
Isopropanol \\
\end{tabular} & 0 & 0 & 0 & 0 & 0 & 0 & 0 & 0 & 0 & 0 & 0 & 0 & 0 & 0 \\
\hline N-Propanol & 0 & 0 & 0 & 0 & 0 & 0 & 0 & 0 & 0 & 0 & 0 & 0 & 0 & 0 \\
\hline Isobutanol & 0 & 0 & 0 & 0 & 0 & 0 & 0 & 0 & 0 & 0 & 0 & 0 & 0 & 0 \\
\hline N-Butanol & 0 & 0 & 0 & 0 & 0 & 0 & 0 & 0 & 0 & 0 & 0 & 0 & 0 & 0 \\
\hline 1-Pentanol & 0 & 0 & 0 & 0 & $\overline{0}$ & 0 & 0 & 0 & 0 & 0 & 0 & 0 & 0 & 0 \\
\hline
\end{tabular}


Table B.2 . (contd)

\begin{tabular}{|c|c|c|c|c|c|c|c|c|c|c|c|c|}
\hline Stream No. & 1946 & 1947 & 1948 & 1949 & 1950 & 1952 & 1953 & 1954 & 1955 & 1956 & 1961 & 1962 \\
\hline Temp F & 720 & 573.7587 & 1000 & 230 & 575.2682 & 227 & 456.3709 & 456.3709 & 715.0002 & 573.7568 & 259.3482 & 259.3462 \\
\hline Pres psia & 450 & 1265 & 1265 & 1280 & 1280 & 450 & 450 & 450 & 1265 & 1265 & 35 & 35 \\
\hline Enth MMBtu/h & -754.41 & \begin{tabular}{ll|}
-796.49 \\
\end{tabular} & -752.34 & -922.42 & -786.6 & -915.58 & \begin{tabular}{|l|}
-778.18 \\
\end{tabular} & -778.18 & -44.398 & -50.257 & -194.85 & -226.91 \\
\hline Vapor mass fraction & 1 & 1 & 1 & 0 & 1 & 0 & 0.99074 & 0.99074 & 1 & $1.00 \mathrm{E}-08$ & 1 & 0 \\
\hline Total lb/h & 137159.141 & 140000 & 140000 & 138246.609 & 138246.609 & 137159.141 & 137159.141 & 137159.141 & 7994.1631 & 7994.1631 & 34160.6445 & 34160.6445 \\
\hline Flowrates in $\mathrm{lb} / \mathrm{h}$ & & & & & & & & & & & & \\
\hline Oxygen & 0 & 0 & 0 & 0 & 0 & 0 & 0 & 0 & 0 & 0 & 0 & 0 \\
\hline Nitrogen & 0 & 0 & 0 & 0 & 0 & 0 & 0 & 0 & 0 & 0 & 0 & 0 \\
\hline Argon & 0 & 0 & 0 & 0 & 0 & 0 & 0 & 0 & 0 & 0 & 0 & 0 \\
\hline Carbon & 0 & 0 & 0 & 0 & 0 & 0 & 0 & 0 & 0 & 0 & 0 & 0 \\
\hline Hydrogen & 0 & 0 & 0 & 0 & 0 & 0 & 0 & 0 & 0 & 0 & 0 & 0 \\
\hline Carbon Monoxide & 0 & 0 & 0 & 0 & 0 & 0 & 0 & 0 & 0 & 0 & 0 & 0 \\
\hline Carbon Dioxide & 0 & 0 & 0 & 0 & 0 & 0 & 0 & 0 & 0 & 0 & 0 & 0 \\
\hline Methane & 0 & 0 & 0 & 0 & 0 & 0 & 0 & 0 & 0 & 0 & 0 & 0 \\
\hline Acetylene & 0 & 0 & 0 & 0 & 0 & 0 & 0 & 0 & 0 & 0 & 0 & 0 \\
\hline Ethylene & 0 & 0 & 0 & 0 & 0 & 0 & 0 & 0 & 0 & 0 & 0 & 0 \\
\hline Ethane & 0 & 0 & 0 & 0 & 0 & 0 & 0 & 0 & 0 & 0 & 0 & 0 \\
\hline Propane & 0 & 0 & 0 & 0 & 0 & 0 & 0 & 0 & 0 & 0 & 0 & 0 \\
\hline Water & 137159.141 & 140000 & 140000 & 138246.609 & 138246.609 & 137159.141 & 137159.141 & 137159.141 & 7994.1631 & 7994.1631 & 34160.6445 & 34160.6445 \\
\hline Sulphur & 0 & 0 & 0 & \begin{tabular}{|l|}
0 \\
\end{tabular} & 0 & 0 & \begin{tabular}{|l|}
0 \\
\end{tabular} & 0 & 0 & 0 & \begin{tabular}{|r|}
0 \\
\end{tabular} & 0 \\
\hline Carbonyl Sulfide & 0 & 0 & 0 & 0 & 0 & 0 & 0 & 0 & 0 & 0 & 0 & 0 \\
\hline Hydrogen Sulfide & 0 & 0 & 0 & 0 & 0 & 0 & 0 & 0 & 0 & 0 & 0 & 0 \\
\hline Ammonia & 0 & 0 & 0 & 0 & 0 & 0 & 0 & 0 & 0 & 0 & 0 & 0 \\
\hline HydrogenChloride & 0 & 0 & 0 & 0 & 0 & 0 & 0 & 0 & 0 & 0 & 0 & 0 \\
\hline Calcium Oxide & 0 & 0 & 0 & 0 & 0 & 0 & 0 & 0 & 0 & 0 & 0 & 0 \\
\hline Benzene & 0 & 0 & 0 & 0 & 0 & 0 & 0 & 0 & 0 & 0 & 0 & 0 \\
\hline Naphthalene & 0 & 0 & 0 & 0 & 0 & 0 & 0 & 0 & 0 & 0 & 0 & 0 \\
\hline Hybrid Poplar Ch & 0 & 0 & 0 & 0 & 0 & 0 & 0 & 0 & 0 & 0 & 0 & 0 \\
\hline Sulfur Dioxide & 0 & 0 & 0 & 0 & 0 & 0 & 0 & 0 & 0 & 0 & 0 & 0 \\
\hline Hydrogen Cyanide & 0 & 0 & 0 & 0 & 0 & 0 & 0 & 0 & 0 & 0 & 0 & 0 \\
\hline Nitric Oxide & 0 & 0 & 0 & 0 & 0 & 0 & 0 & 0 & 0 & 0 & 0 & 0 \\
\hline Methanol & 0 & 0 & 0 & 0 & 0 & 0 & 0 & 0 & 0 & 0 & 0 & 0 \\
\hline Ethanol & 0 & 0 & 0 & 0 & 0 & 0 & 0 & 0 & 0 & 0 & 0 & 0 \\
\hline Isopropanol & 0 & 0 & 0 & 0 & 0 & 0 & 0 & 0 & 0 & 0 & 0 & 0 \\
\hline N-Propanol & 0 & 0 & 0 & 0 & 0 & 0 & 0 & 0 & 0 & 0 & 0 & 0 \\
\hline Isobutanol & 0 & 0 & 0 & 0 & 0 & 0 & 0 & 0 & 0 & 0 & 0 & 0 \\
\hline N-Butanol & 0 & 0 & 0 & 0 & 0 & 0 & 0 & 0 & 0 & 0 & 0 & 0 \\
\hline 1-Pentanol & 0 & 0 & 0 & 0 & 0 & 0 & 0 & 0 & 0 & 0 & 0 & 0 \\
\hline
\end{tabular}






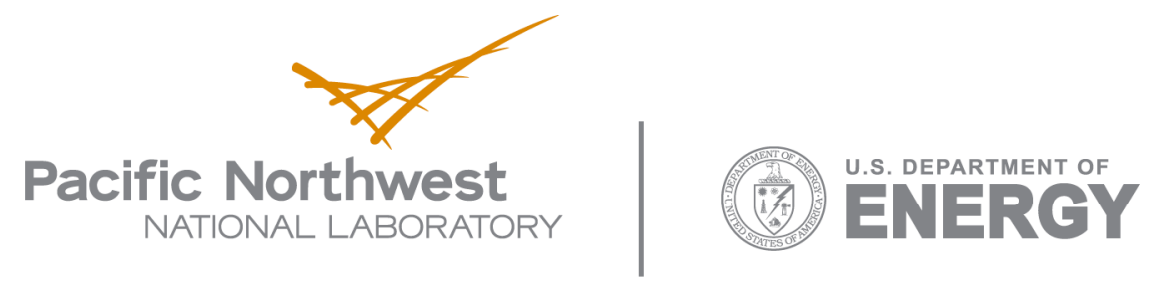

902 Battelle Boulevard

P.O. Box 999

Richland, WA 99352

1-888-375-PNNL (7665)

www.pnl.gov 